Historic, Archive Document

Do not assume content reflects current scientific knowledge, policies, or practices. 



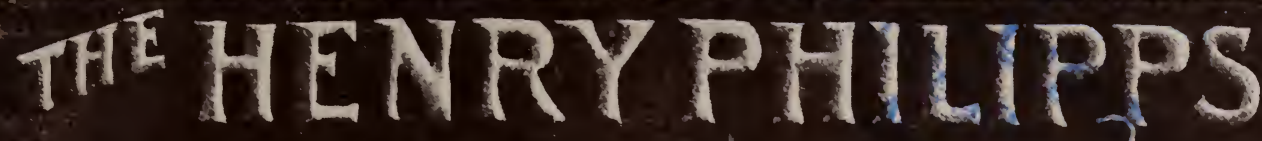 SEED E IMPLEIMENT CO. GROWERS IMPORTERS} WHOLESALE ERETAIL DEALERS IN GARDEN FIELD

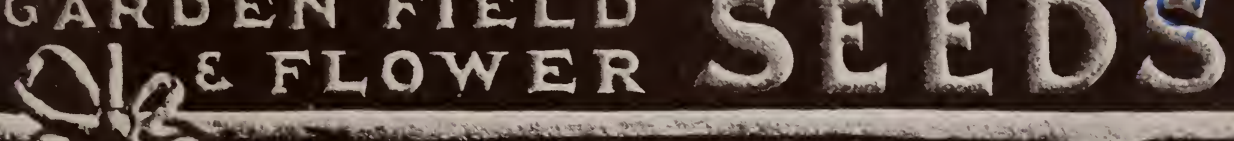

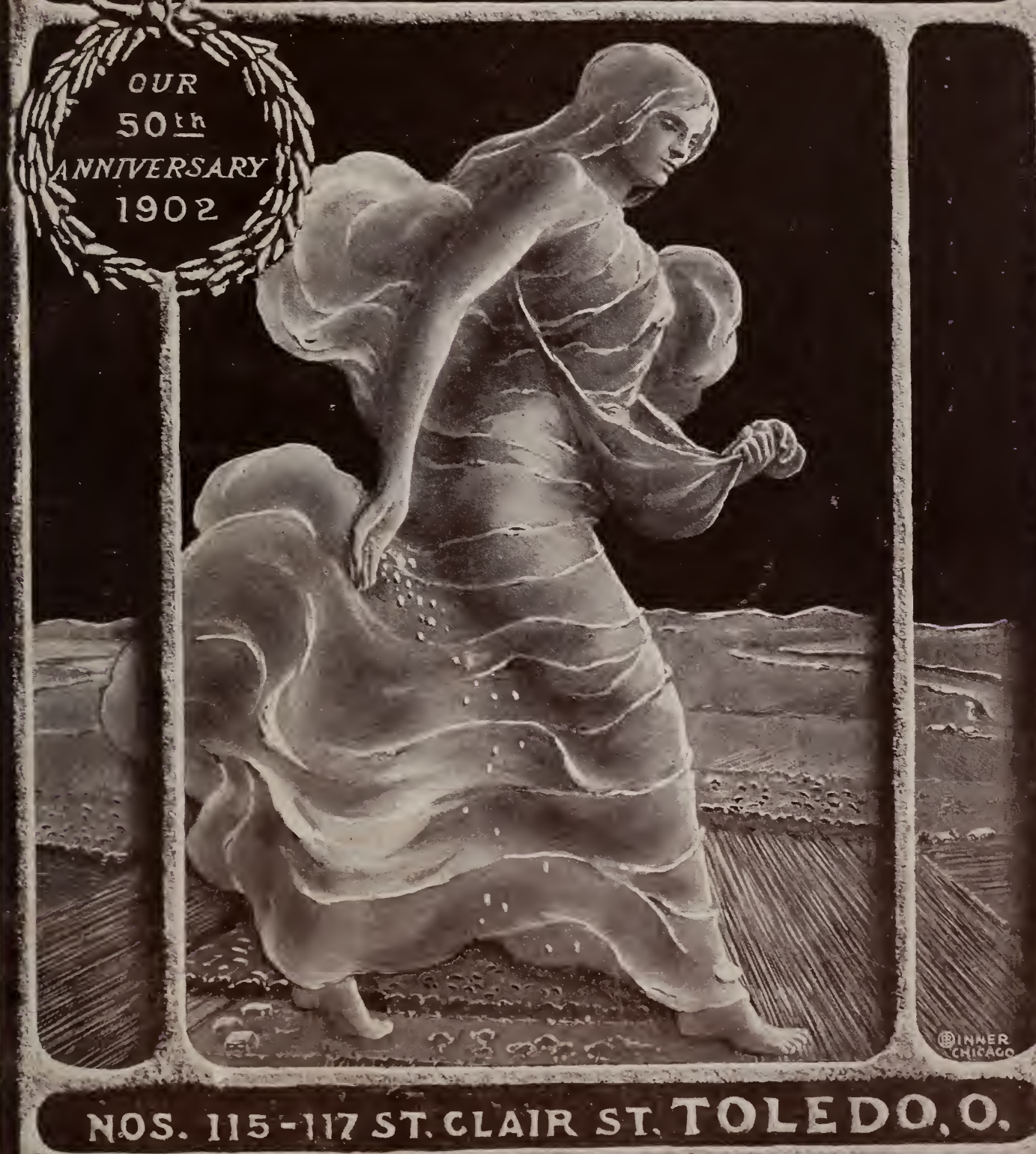




\section{TO OUR FRIFENDS AND CUSTOMERS.}

With inuch pleasure we present to you our Annual Catalogue for 190\%. Fifty years ago Mr. Henry Philipps established our business that has grown in volume each year. To prove to you that we are careful and pains. taking in supplying none but the best seeds, we were awarded the entire U. S. Government Seed Contract for 1897 and 1898, and again the present contract for 1901 and 1902 , a mounting to over $39,000,000$ packets of seed that we are now sending out from Washington, D. C.

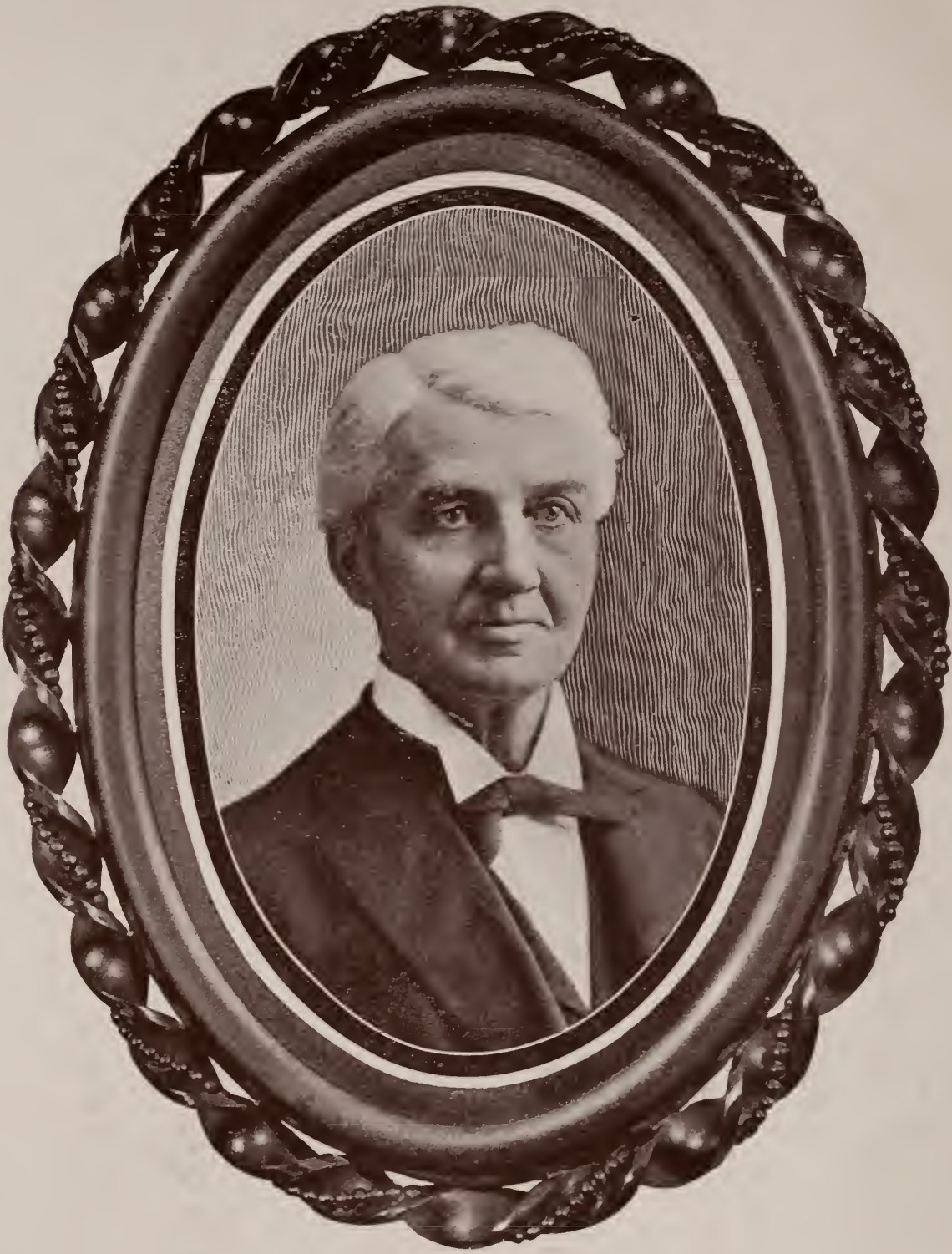

HENRY PHILIPPS.

Founder of the Henry Philipps Seed and Implement Company.

Please remember we are Growers and Importers of all kinds of Garden, Field and Flower Seeds, and can sell you just as Good Seed as any seedsman has to offer.

Kindly read our Catalogue over carefully in its different departments and we know you will find much to interest you.

We want your trade and ask that you let us know your wants when we will he pleased to mail you any information at our command, also quote youright prices for best Seeds and Implements money will buy.

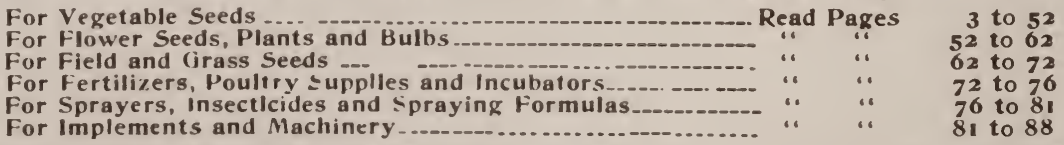

Put this Book where you can find it when wanted, or better still, send us your order at once, and have flled before the rush at seeding time.

Be neighborly and trade your money for our goods.

We shall hope to hear from you soon and olten during the year 1902. 


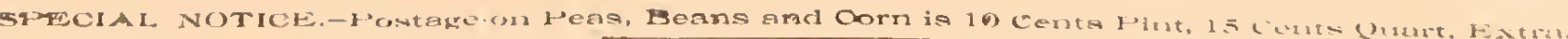

ORDER SHEET. THE HENRY PHILIPPS SEED HND IMIPLEMENT CO., TOLEDO, 0.

Please be particular and WRITE YOUR NAME AND ADDRESS DISTINCTLY AND IN FULI WITH EACM ORDER.
Order early and often and we shall try hard to please you.

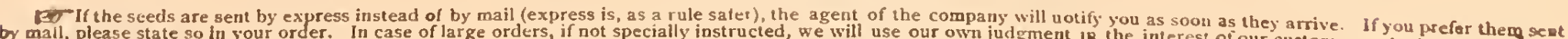

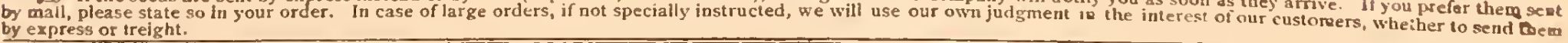

Please forward the following order :

Name

Post () pfick

Counly

State

Hreight or

Hixpress Office

Quantity.

Articles Wanted,
Amount enclosed, P.O. Order, \&

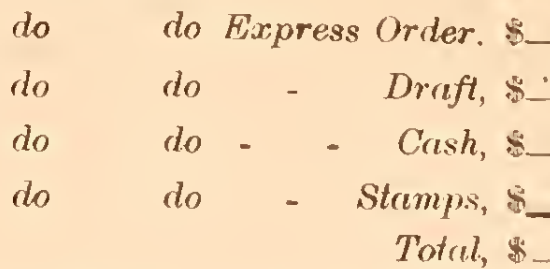

Date 190

Price. Quantity

Artictes Wanted.

Prict. 



\section{PIONEER SEED HOUSE OF TOLEDO.}

\section{FIFTY YEARS' EXPERIENCE.}

The Market Gardener or progressive, practical farmer does not look for CHEAPNEss when buying his seed. What he wants is Seed TRUE TO NAME and of sTrovg viTALITX, which he certainly gets when he buys Philipps' Proneer Brand Seeds.

We were "born and raised" in the seed Business, and our customers get the benefit of a lifetime of experience. Our customers also have the advantage of our unequalled shipping facilities. Toledo, with twenty. five railroads. besides eight express companies, many steamship lines and central location, is far ahead of any other city in tinis respect.

We have many Seeds in stock, that on account of lack of room, we cannot catalogue, so please remember that we can furnish any kind of Seeds that any seedsman can. and do not hesitate to send to us for anything in that line. Also look through the other departments, you may find there just what you are looking for.

MAIL ORDER BUSINESS. - We have no canvassers or agents to solicit orders. All outside business is done through mail orders direct to us. This means a saving to our patrons as well as to the firm. Close and prompt a.tention to such orders and honorable dealing have assured us a steady growth, and we now enjoy an immense mail order business. Our friends and patrons have found by experience that buying through letter is fe and satisfactory as buying over the counter, and have materially assisted in the extension of our bres.

SEEDS POSTPAID BY MAIL.-All Vegetable and Flower Seeds by the packet, ounce or pound, will be delivered by us, postage paid and fRee of All expense. When Beans, Corn and Pras are ordered we have to request an additional 15c. per quart, to be added for part postage on same. This system places our store at your very door and enables customers thousands of miles away to obtain their supplies as cheaply as if they called in person at our store.

NOVELTIES. - We devote considerable time each year to testing the various so-called novelties offered by the seed dealers of this and other countries, and whenever we discover anything desirable we offer it to our customers. In each department of this catalogue we offer a number of well tested noveltes, which we are sure will prove satisfactory.

QUALITY OF SEEDS.-We don't buy cheap Seeds. We have our Seeds grown by the most celebrated and reliable Seed growers, and it is our constant aim to send out ouly Seeds of superior quality, and the prices we ask for them will compare favorably with those of any first-class house, We guarantee that all our Seeds are of good germinating quality. All persons conversant with horticultural operations will, however, know that at times the best of seeds fail to grow, owing to causes we cannot control and entirely beyond our responsibility.

ADDRESS, Etc - In ordering please be particular to write your NAME, also that of yonr POSTOFFICE, CoUnTY and STATE plainly, also mention the mode of conveyance you prefer-whether by mail, express or freight. Serious delays are sometimes occasioned by failure to give attention to these matters. When not specified we shall use our best judgment. When goods are sent $C$. O. D., return charges will be added. As the prices of articles are catalogued. the purchaser can save the return charges by enclosing the rcmittance with the order.

ORDER EARLY. - The best time to order is just as soon as you receive this catalogue, as we can always give your orders more of our personal attention if they come in before the rush of the Spring trade. Please use our order sheet, as it makes it more convenient for us in filling orders.

GUARANTEE.-Complaints made that Seeds are not good, should quite as often be attributed to other causes as to the quality of the seeds. There are contingencies continually arising to prevent the very best Seeds always giving satisfaction, such as sowing too deep, too shallow, in too wet or too dry soil, insects of different descriptions destroying the plant as soon or before they appear; wet weather, cold weather, frosts, chemical changes in the Seeds, induced by temperature, etc. For these reasons it is impracticable to guarantee seeds under all circumstances, and while we exercise the greatest care to have all Seeds pure and reliable, we do not give any warranty expressed or implied. If the purchaser does not accept the Seeds on these terms. and conditions, they must be returned at once, and the money that has been paid for them will be refnnded.

HOW TO SEND MONEY.-Cash should always accompany the order. We will be responsible for money sent us by Postoffice Order, Express Money Order, Bank Draft, Express, or by Registered Letter.

Bills, Coin, or Stamps (we accept postage stamps same as cash) can be sent safely by registered letter. Every postmaster is required to register any letter on payment of eight cents extra pastage. We will in no way be responsible for Stamps or Money enclosed in a letter without registering. In case it is possible to send in no other way than U. S. Postage Stamps we prefer the two cent letter stamps, and care should be taken not to have them get moist and stick together. 


\section{P H I L I P P S \\ Northern Grown, Double Tested, Pioneer Brand
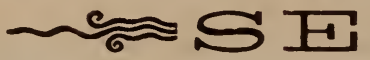 \\ 耳
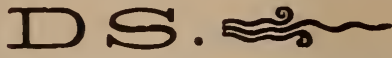

ALL OUR SEEDS ARE TESTED

Very carefully, and a record is kept of the percentage of each variety that grows, so nothing is sent out bur will germinate and prove as represented, We do not sell undersized packets at 3 cents, but advertise out 5 cent packets that hold 5 cents worth of seed, and any one buying them can easily see the difference as compared with the 3 cent packets sold by some other seedsman.

We put nothing out on commission, therefore have no old seed returned at the end of the season to be disposed of the next year.

\section{SPECIAL OFFER ON SEEDS IN PACKETS.}

Thls offer is by Mall. Postage Pald by Us to any Postoffice in the United States.

Packet Seed Discounts. - This does not refer to Seeds offered by weight or measure, but to seed $\Omega$ packets only. Nor does it refer to Potatoes, Onion Sets, or Bulbs.

For 25 cents you may select 6 five cent packages of Vegetable or Flower Seeds.

For 50 cents you may select 15 five cent packages of Vegetable or Flower Seeds.

For $\$ 1.00$ you may select Seeds in Packets (vo ounces remember) to amount of $\$ 1.50$.

For $\$ 8.00$ you may select Seeds in Packets (no ounces remember) to amount of $\$ 3.85$.

For $\$ 5.00$ you may select Seeds in Packets (no ounces remember) to amount of $\$ 8.50$.

\section{BULK SEED DISCOUNTS TO LARGE CONSUMERS.}

This discount refers to Seeds quoted in catalogue by weight or measure, and not to Potatoes, Onion Sets, or Clover, Timothy and other Grass and Field Seeds, as some mistook it last season, neither to Seeds in packets.

On an order of $\$ 5.00-10$ per cent.

On an order of $\$ 10.00-12$ per cent.

On an order of $\$ 20.00-15$ per cent.
On an order of $\$ 5000-18$ per cent

On an order of $\$ 100.00-20$ per cent.

On an order of $\$ 500.00-25$ per cent.

\section{BIG COLLECTION.-\$1.00 BY MAIJ, POSTPAID.}

1-One Pkt. Beans, Refugee or 1,000 to 1.

2- " Beans, Golden Wax.

3- " Beet, Early Blood Turnip.

4- “ Cabbage, Extra Early Jersey Wakefield

5- “ Cabbage, Improved Autumn King.

8- “ Celery, White Plume.

7- “ Corn, Sweet, Stowell's Evergreen.

8- " " Cucumber, Long Green Improved.

9- " Cucumber, Toledo Market Evergreen.

10- “ Lettuce, Grand Rapids.

11 - “ Lettuce, New Salamander.

12- “ Watermelon, Improved Dixie.

13- “ Muskmelon, Extra Early Hackensack.

14- " Onion, Yellow Danvers.

15- " Onion, Prize Taker.

16- " Pepper, Ruby King.
17-One Pkt. Parsnip, Hollow Crown.

18- “ Peas, Philipps' Early Summit.

10 - " Peas, Telephone, Late.

20- " Radish, Early Scarlet Turnip.

21- " Radish, Improved Chartier.

28- " Squash, Toledo Warted Hubbard.

23- " Tomato, Improved Stone.

24- " Tomato, Dwarf Clampion.

25- “ Turnip, Purple Top, Strap Leaf.

26- " Turnip, Monarch Swede Ruta Baga.

87- ‘ Sweet Peas, Mixed Flowering.

28- .. Mignonette, Sweet.

29- “ Balsam, Double Mixed.

30- " Pansy, Mixed.

31- " Nasturtium, Mixed.

32- " Zinnia.

You cannot beat this collection for the money.

Remember these are full-sized packets.

\section{To Market Gardeners}




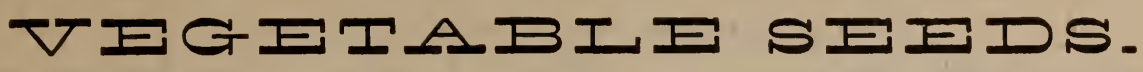

ARTICHOKE.

CULTUPE.-Sow in April in rich soil and transplant to permanent beds the next Spring, in hills three feet apart each way, with three plants to a hill. A rich deep loam is required and plenty of moisture.

The Globe Articnoke is cultivated for its flower heads, which are cooked like Asparagus. On account of its hardiness, easy culture and perennial nature, plants w.1l remain in bearing a long time. Sow seed in April and May.

Large Green Globe is the most popular and best for general cultivation. Paper 5c; oz. 30c; 1b. 12.50.

Tuberous-Rooted Artiohoke-Nuw Whiтв. Well known throughout the country. The roots are esteemed for pickling and profitable crop to grow for feeding hogs, colts, calves and sheep. Yie d sometımes 1,000 bushels per acre. Like parsnips freezig solid and thawing many times does not spoil them; so it is not necessary to dig them for Spring use. Six bushels plant an acre. Per peck 50c; bushel $\$ 1.75$. If by mail, postpaid, $25 \mathrm{c}$. per lb.

\section{ASPARAGUS.}

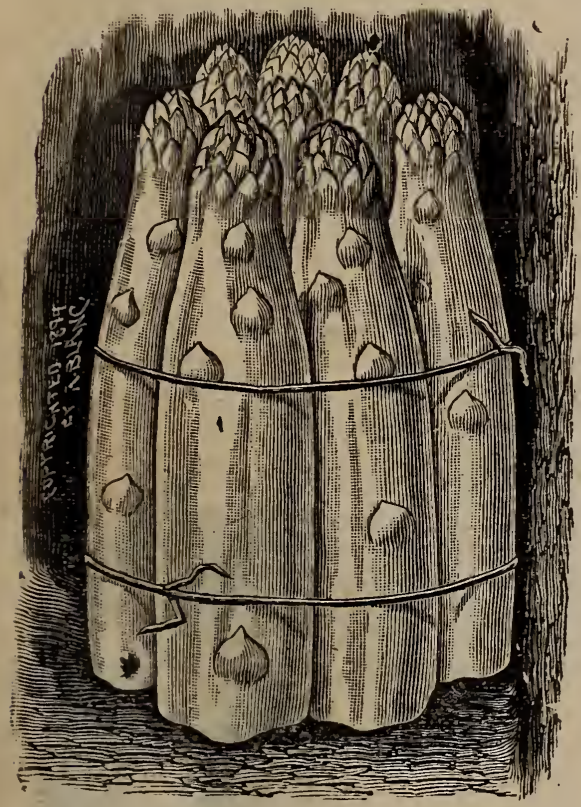

CULTURE,-Sow esrlv in Spring in drills two inches deep, rows one foot apart, keep clear from weeds by frequent weeding. When one or two years old transplant into permanent beds, which should be made rich by plenty of manure. The perfection of the shoots depend mainly upon the favorable condition of the soil. Set the plants in the rows about one foot apart, with crown of the root three inches below the surface. Every Fall remove the stalks and apply a good dressing of manure. which it would be well to stir in the following Spring with a liberal dressing of fine salt.

Conover's Colossal. A well tried standard variety; large size quick growth, excellent quality. Pkt. $5 \mathrm{c} ; 0 \mathrm{z} .10 \mathrm{c} ; 1 / 4 \mathrm{lb} .15 \mathrm{c}$ $1 \mathrm{lb} .50 \mathrm{c}$.

Palmetto. Very early and desirable on account of its large size even and regular growth, great productiveness and excellent quality. Pkt. $5 \mathrm{c}$; oz. $10 \mathrm{c} ; 1 / 4 \mathrm{lb} .20 \mathrm{c} ; 1 \mathrm{lb} .60 \mathrm{c}$.

Barr's Yammoth. Of very large, quick growth. Earlier than the Conover's Colossal and more than twice as large. It is wonderfully productive throughout the entire seasou; very tender and very delicious flavor. Pkt. $5 \mathrm{c} ; 0 \mathrm{z} .10 \mathrm{c} ; 1 / 1 \mathrm{lb} \mathrm{lb} 20 \mathrm{c} ; 1 \mathrm{lb} .65 \mathrm{c}$.

Columbian Mammorh White. This variety is a sport from Conover's Colossal, and originated on the farm of a prominent Asparagus grower on Long. Island. It produces pure white shoots and requires no artificial blánching. On this account it brings in the market a much higher price than any other sort. It is a strong grower and comes remarkably true from seed-not more than ten per cent. reverting to the type. Pkt. $5 \mathrm{c} ; \mathrm{oz} .10 \mathrm{c}$; 1/4 lb. 20c; 1 lb. $75 \mathrm{c}$.

\section{A SPARAGUS ROOTS.}

By purchasing Good STRONG Roors one or two years' time is saved.

Columbian Mammoth White. By mail, postpaid, 50 roots, $\$ 1.00 ; 100$ roots, $\$ 1.50$. By express, not prepaid, 100 roots, $75 \mathrm{c} ; 500$ roots, $\$ 2.50 ; 1,000$ roots, $\$ 5.00$.

Conover's Cotossal. By mail, postpaid, 50 roots, $50 \mathrm{c} ; 100$ roots, $90 \mathrm{c}$. By express, not prepaid, 100 roots, $60 \mathrm{c} ; 50$ roots, $\$ 2.00 ; 1.000$ roots, $\$ 4.00$.

Palmetto. By mail, postpaid, 50 roots, $70 \mathrm{c} ; 100$ roots, $\$ 1.25$. By express, not prepaid. 100 roots, $60 \mathrm{c} ; 500$ roots, $\$ 2.50$; 1.000 roots, $\$ 5.00$.

Barr's Mammoth. By mail, postpaid, 50 roots, 70c; 100 roots, $\$ 1.25$. By express, not prepaid, 100 roots, $60 \mathrm{c} ; 500$ roots, $\$ 2.50 ; 1,000$ ronts, $\$ 1.50$.

\section{BEANS.}

\section{DWARF BUSH VARIETIES.}

The Bean crop hardly an average one this year and prices firmer.

Of the many varieties of Beans, the following list comprises the very best of all, of which our stock is extra choice the stock each year being carefully "rogued" and the seed stocks im proved by continued intelligent selection.

CULTURE.-About the first of May select a warm, dry, sheltered spot; dig and manure slightly; make drills two inches deep and two feet apart; drop the Beans three inches apart in the drills and cover not more than two inches deep ${ }^{\circ}$ Keep hoed (when not wet) and the weeds killed. Sow every two weeks for a succession.

PHILIPPS' DWARF OR SNAP BEANS.-Green Poddrd Variztdrs.

White KidneJ. Excellent, either green or ripe ; early and very prolific. Pkt. 5c; pint 10c; quart $27 \mathrm{c}$; peck $\$ 1.00$.

White Marrowfat. Good as either a string or shell Bean; heavy croppes. Pkt. $5 \mathrm{c}$ : pint $10 \mathrm{c}$; quart $20 \mathrm{c}$; peck $\$ 1.00$.

White Navy, or Boston Pea Beans. Pkt. $5 c$; pint $10 c$; quart $15 c$; peck $75 c$. 


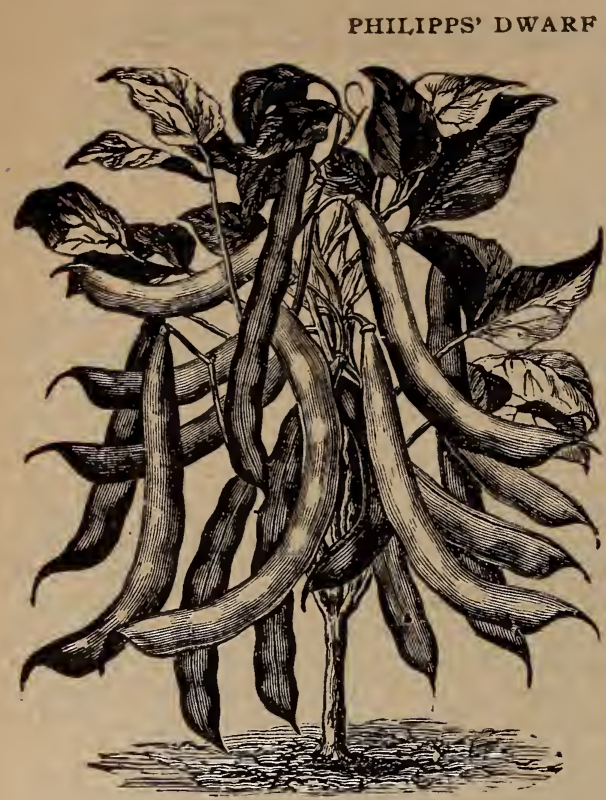

IMPROVED EXTRA EARLY ROUND POD RED SPECKI.ED VALENTINE.

Improved Extra Early Round Pod Red Speckled Valentine. A select strain of Early Red Valentine, ripening very uniformly and producing enormously. Pods tender and succulent; the most profitable sort for the gardener; ready to pick in 35 days. Pkt. $5 \mathrm{C} ; 1 / 2$ pint $10 \mathrm{c}$; pint $15 \mathrm{c}$; quart $20 \mathrm{c}$; peck $\$ 1.00$.

Early Mohawk. Long, flat and Straight pod; very hardy. Pkt. $5 c$; $1 / 2$ pint $10 \mathrm{c}$; pint $15 \mathrm{c}$; quart $20 \mathrm{c}$; peck $\$ 1.00$.

Long Yellow Six Weeks. Extra Early and a most excellent variety; the leading market sort; has full, flat pods. Pkt. 5c; $1 / 2$ pint $10 \mathrm{c}$; pint $15 \mathrm{c}$; quart $20 \mathrm{c}$; peck $\$ 1.00$.

Horticultural Dwarf. Excellent quality as a shell Bean, either green or dry; equal to the pole Bean, easier to cultivate. Pkt. $5 \mathrm{c}$; $1 / 2$ pint $10 \mathrm{c}$; pint $15 \mathrm{c}$; quart $20 \mathrm{c}$; peck $\$ 100$.

Canadian Wonder, or Rose Bean. Of very dwarf habit. Pods tender and delicious, growing long, frequently fifteen inches. Pkt. $5 \mathrm{c} ; 1 / 2$ pint $10 \mathrm{c}$; pint $15 \mathrm{c}$; quart $20 \mathrm{c}$; peck $\$ 1.00$.

The Goddard, or Boston Favorite. Particularly valuable as a shell Bean, being very large, handsome, and of delicious flavor either green or dry ; it is very productive. Pkt. $5 \mathrm{c}$; $1 / 2$ pint $10 \mathrm{c}$; pint $15 \mathrm{c}$; quart $20 \mathrm{c}$; peck $\$ 1.00$.

Refugee, or 1000 to 1 . Medium to late; very productive and tender, and largely grown for main crop; round pod. Pkt. $5 c$; $1 / 2$ pint $10 c$; pint $15 \mathrm{c}$; quart $20 \mathrm{c}$; peck $\$ 1.00$.

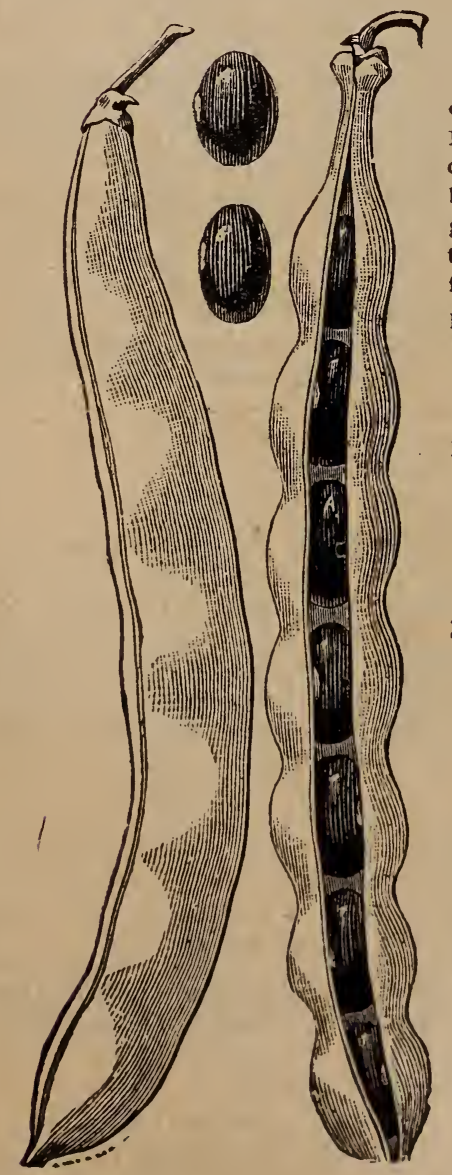

\section{BUSH LIMAS.}

The Bush Limas grow without aid of stakes or poles, in compact bush form, 15 or 18 inches high; produce enormous crops of delicious Lima Beans which can be as easily gathered as the common garden bush Bean. They are earlier than the climbing Limas and bear until frost.

Henderson Bush Lima or Dwarf Sieva. Thel first introduced. Pkt. $5 c$; $1 / 2$ pint $10 \mathrm{c}$; pint $15 \mathrm{c}$; quart $30 \mathrm{c}$; peck $\$ 2.25$.

Burpee's Bush Lima, A bush form of the large pole Lima, the Beans being large and flat, like those of that variety. It is very productive and its dwarf chdracter is well established. Pkt. $5 c$; $1 / 2$ pint $10 c$; 'pint $15 c$; quart 30c : peck \$2.25.

\section{PHILIPPS' DWARF WAX PODDEI) VARIETIES.}

Currie's Rust-Proof Golden Wax. It is positively rust-proof. While grown side by side for several years with other Wax Beans, all of them more or less affected by rust, many of them completely ruined by it, this Bean has remained entirely free from it. Exceedingly crisp and tender, and of a most delicious flavor. As early as the Golden Wax, and it is moreover amazingly productive. Habit upright and robust, holding the pods well from the grousd, pods long, flat and straight, of a beautiful golden color; the best Black Wax Bean out. Pkt. $5 c$; $1 / 2$ pint $10 \mathrm{c}$; pint $15 \mathrm{c}$; quart $25 \mathrm{c}$; peck $\$ 1.50$.

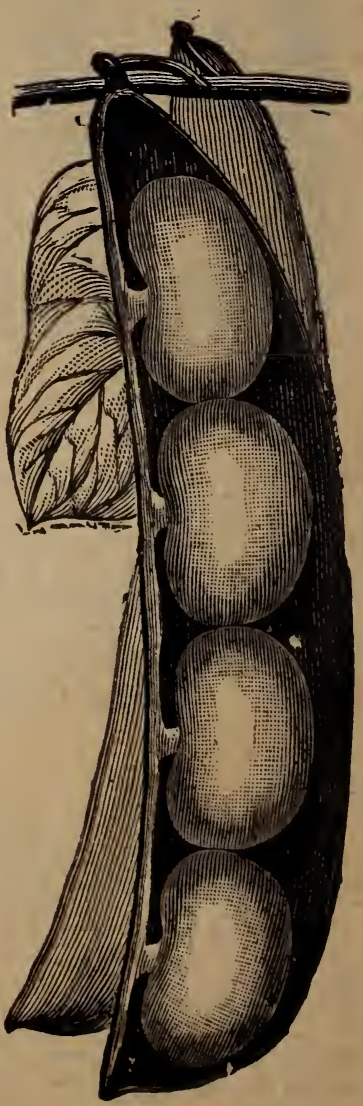

BURPEE'S :BUSH LIMA BEAN. 
PHILIPPS' DWARF WAX PODDKD VARIETIES-CONTINUED.

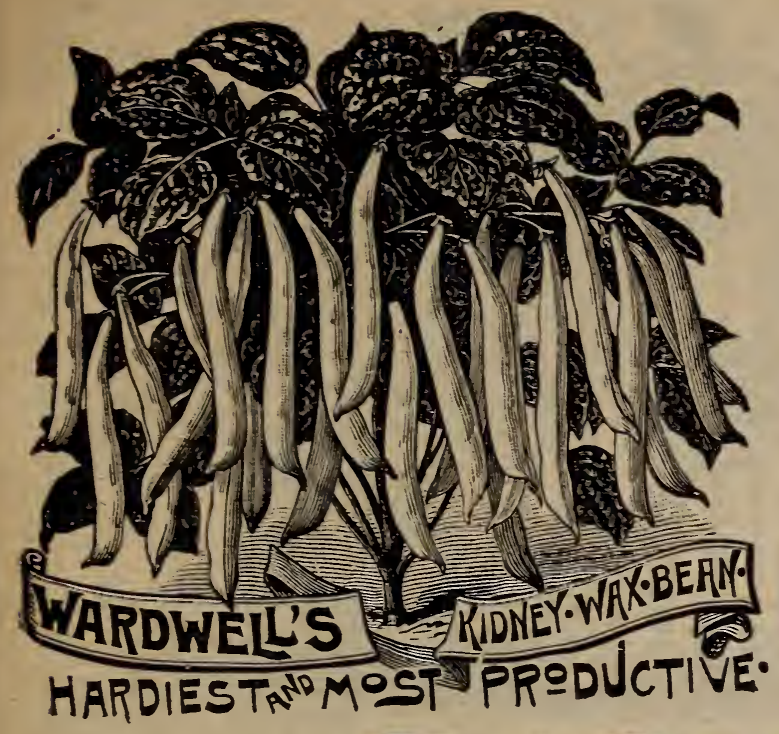

Wardwell's Dwarf Ridney Wax. Extra early, hardy and productive; pods iong. broad, flat, and of a delicate waxy yellow brittle and entirely stringless; decidedly the best Bean for market gardeners. Our price on this Bean lower than other seedsmen sell them should insure us your order. Beans white with two shades of reddish purple, and a distinct kidney shape; remarkably free from rust; excellent flavor. Pkt. $5 c$; $1 / 2$ pint $10 c$; pint $15 c$; quart $25 c$; peck $\$ 1.50$.

We are re-cleaners of all kinds of Field Seeds and do not mix Medium with Mammoth Red Clover. Read over carefully pages 63 to 73 , Field Seed Department.

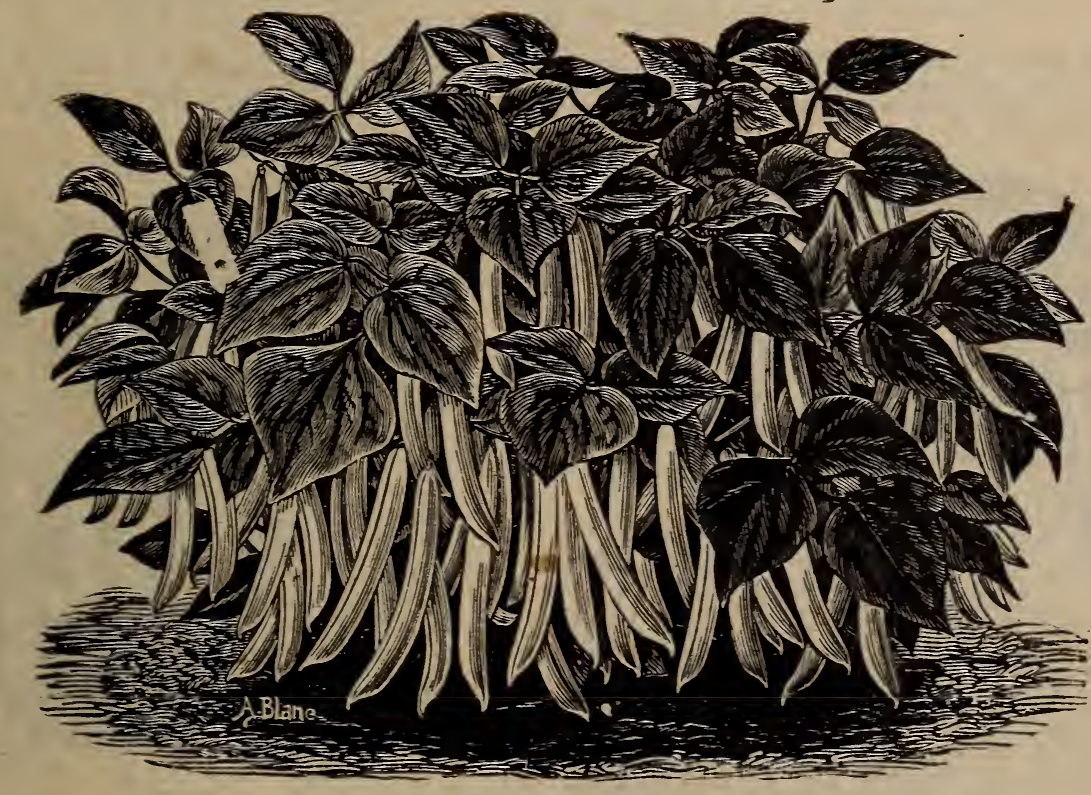

THE DAYIS KIDNEY WAX.

The Davis Kidney Wax Bean. This is a NRW and distinct KIDNRY Wax variety of late introduction, and proved without exception to be the best white seeded wax podded Bean known. The plant is vigorous and healthy, of compact, upright growth, carrying its pods on the center and well up from the ground. It is very productive, always giving a large yield of handsome pods. with a small proportion of imperfect and misshapen ones. The pods are very long, oval, clear waxy-white color, and when suitable size to use for snaps quite stringless, showing no tendency to string unti thcy approach maturitv. Practical market gardeners are delighted with it because of its earliness, hardiness. productiveness, handsome a ppearance, its good shipping and selling qualities and small proportion of waste and second quality pods. Canners say it is just what we want, a long straight, clear white pod which does not disco or in canning. The large bandsome kidney-shaped dry beans are attractive and this new Bean is sure to become 2 very popular and standard sort for fami y garden as well as market, and we highly recommend it to our fricnds to give it a trial. Pkt. $5 c$; $1 / 2$ pint $10 c$; pint $15 c$; quart $25 c$; peck $\$ 150$.

We do not handle any Vegetable Seeds but those that germinate up to the Government Standard. and all the Vegetable Seeds sold by us are grown under our own careful supervision by the most experienced seed farmers, who make it their business to grow nothing but Seed Stocks. 
PHILIPPS' DWARF WAX PODDED TARIETIES-CONTINUID.

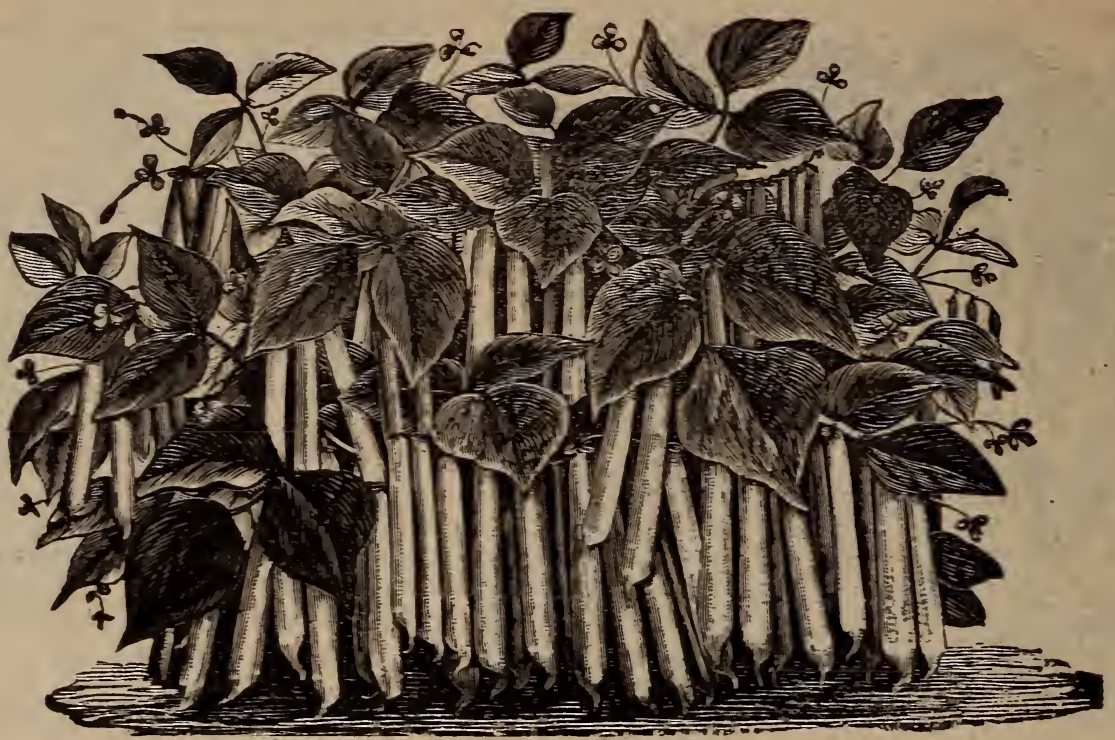

INPROVKD GOLDEN WAX.

Improred Golden Wax. (Rust-proof). The handsomest and hardiest of all the Wax Beans. Very productive; pods straight, broad and a beautiful golden wax; quality very excellent. It is also one of the very best green shelled Beens and excellent dry. We recommend it to all. Pkt. $5 \mathrm{c}$; $1 / 2$ pint $10 \mathrm{c}$; pint $15 \mathrm{c}$; quart $25 \mathrm{c}$; peck $\$ 1.50$.

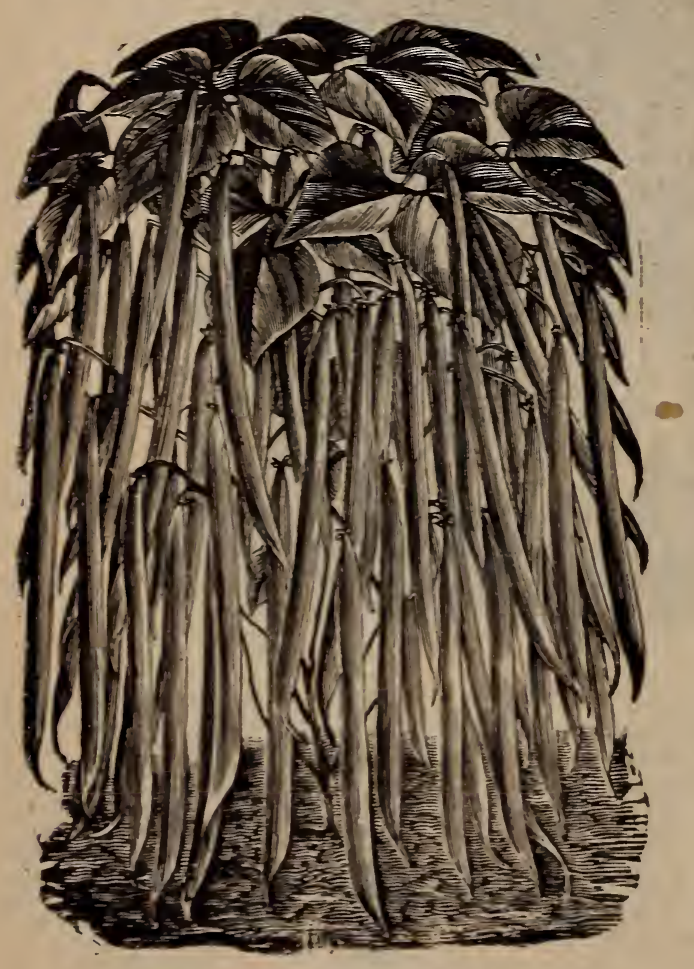

DWARF RED FLAGEOLET WAX.

Dwarf Red Flageolet Wax. Pods very large, sometimes 10 to 12 inches in length. entirely stringless, very fleshy, exceedingly tender and succulent; one of the heaviest yielders and nearly a ways exempt from rust. PKt. $5 c$; $1 / 2$ pint $10 c$; pint $15 c$; quart $25 c$; peck $\$ 1.50$.

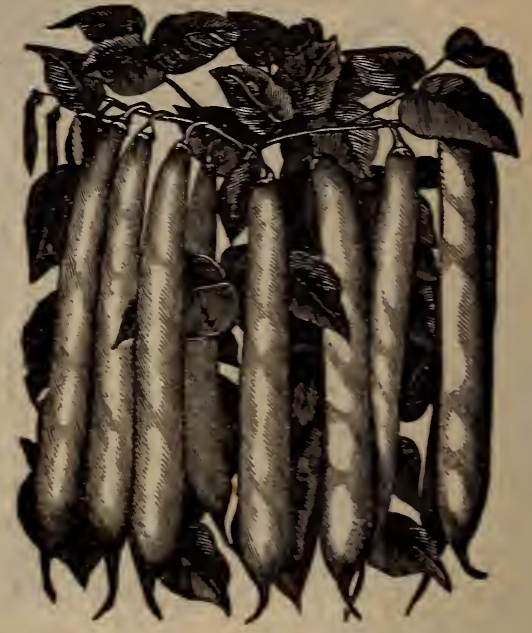

NEW PROLIFIC GERMAN, OR CYLINDER BLACE WAX BUSE BEAN.

New Prolific German, or Cylinder Black Wax Bush Bean This is an entirely new and improved strain of th- old favorite German or Black Wax Bean, earlier and very p'oductive Pods perfectly rourd, straight, long, and of an even rich go den color. Pkt. $5 c$; is pint 10c: pint $15 \mathrm{c}$; quart $25 \mathrm{c}$; peck $\$ 150$.

Read second page carefully and you will be convinced that we sell good Seed cheaper than other Seedsmen. Also order Seed Collections offered on page twenty-four. 


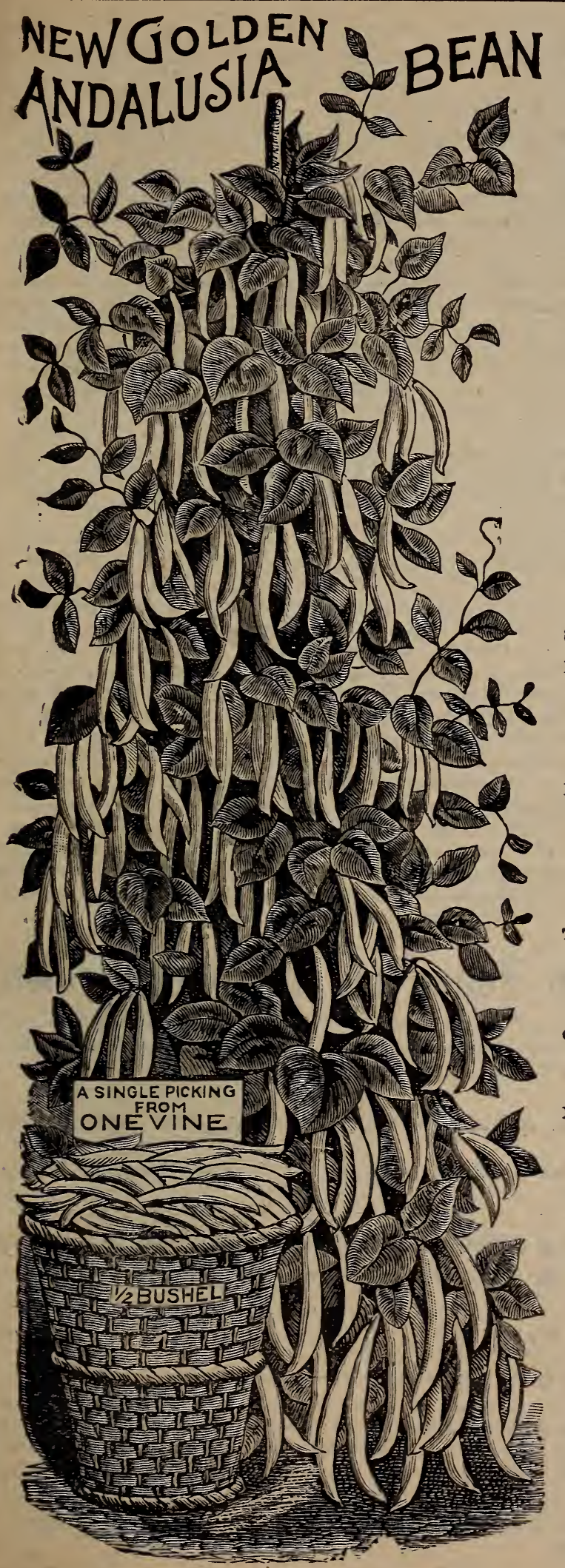

PHILIPPS' POLE OP RONNIIGG BEANS.

CULTURE.-Sow as soon as the soil becomes warm and dry, from the first of May (for all except Limas) to the latter part of May, in hills four feet apart each way, Limas should not be planted until warm weather has fairly set in. One quart of Limas will plant about 100 hills, allowing four or five beans to a hill, and of the smaller sorts about 200 hills. Poles eight to ten feet long should be set firmly in the center of the hills before putting in the seed.

Horticultural or Speckled Cranberry. Showy and excellent either snap or shell Beans. A popular variety. Pkt. $5 \mathrm{c} ; 1 / 2$ pint $10 \mathrm{c}$; pint $15 \mathrm{c}$; quart $25 \mathrm{c}$; peck $\$ 1.50$.

Dutch Case Knife. White seeded. Podslong, green and flat; can be either snapped or shelled when used; also for pickling. Pkt. $5 \mathrm{C}$; $1 / 2$ pint $10 \mathrm{c}$; pint $15 \mathrm{c}$; quart $30 \mathrm{c}$; peck $\$ 1.50$.

Scarlet Runner. A popular English pole Bean ; very ornamental, producing scarlet flowers; good for snap or green sheled. Pkt. Ec; $3 / 2$ pint $10 \mathrm{c}$; pint $20 \mathrm{c}$; quart $30 \mathrm{c}$; peck $\$ 1.50$.

Seibert's Extra Early Lima.)

Extra Early Jersey Lima.

Mature ninety days from germination. Yield about eighty bushels green pods per acre. Pkt. $5 c$; $1 / 2$ pint $10 c$; pint $15 c$; quart $30 c$; peck $\$ 2.25$.

Extra Large or Mammoth White Lima This is the largest of all the Limas. The pods are of enormous size and containing from five to eight beans. Largely grown and highly esteemed. Plt. 5c; 4 pint $10 \mathrm{c}$; pint $15 \mathrm{c}$; quart $30 \mathrm{c}$; peck $\$ 2.25$.

Tall German Wax (Indian Chief). Black seed. A good snap sort, maturing in seventy. five days; also good for shell Beans Pkt. $5 \mathrm{c}$ $1 / 2$ pint $10 \mathrm{c}$; pint $20 \mathrm{c}$; quart $35 \mathrm{c}$. peck $\$ 2.25$.

Giant Red Wax. Pods long, yellow and tender; very good. Pkt. $5 c$; $/ 2$ pint $10 c$; pint $20 c$ quart $35 \mathrm{c}$; peck $\$ 2.25$.

New Golden Andalusia Wax Bean. This new Bean has created a decided sensation. Hundreds pronounce it emphatically the most valuabie pole variety ever offered. It originated in Andalusia, Bucks county, $\mathrm{Pa}$, with a celebrated Bean grower. Our illustration gives some idea of its wonderful productiveness. It is nothing unusual to pick one-half bushel to three pecks from a single vine at one pickingl The pods are five to six inches long, broad, thick, very fleshy and entirely stringless, far surpassing all other varieties in this respect and retaining these important qualities until almost ripe. Exccedingly rich, buttery and fine flavored. The vines cling well to the poles, a very important feature, as the weight of a vine filled with such a mass of large pods is very great. They commence bearing in great abundance when the vines are quite young, and coutinue to bear profusely the entire season. The Beans when dry:are as 


\section{POLE OR RUNNING BEANS-CONTINURD.}

round as a bullet, pure white in cclor, and also make a fine shell or winter Bean. Large pkt. 10c; pint $25 \mathrm{c}$ : quart $30 \mathrm{c}$; 4 quarts $\$ 1.60$; peck $\$ 2.00$.

White Creaseback Pole. Exceedingly productive; In clusters of from four to twelve handsome green pods. six inches long, perfectly round, entirely stringless; very fleshy Pkt. $5 \mathrm{c} ; 1 / 2$ pint $10 \mathrm{c}$; pint $15 \mathrm{c} ;$ quart $25 \mathrm{c}$ : peck $\$ 1.50$.

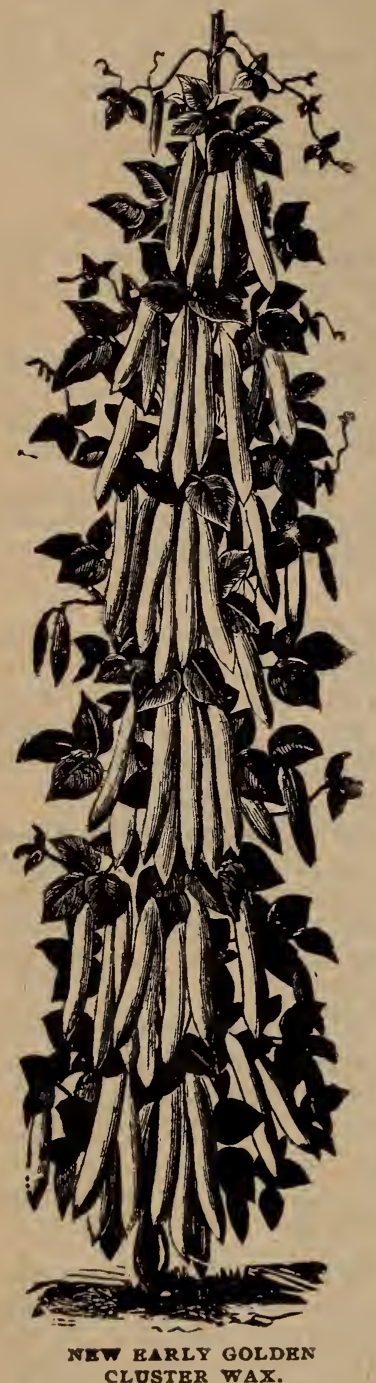

Red Speckled Cut-Short, or Cornhill. An old variety, very popular for planting a mong corn, and will give a good crop without the use of poles: vines medium, with dask colored, smoolh leaves : pod short, cylindrical and tender. Pkt. $5 \mathrm{c}$; $1 / 2$ pint $10 \mathrm{c}$; pint $15 \mathrm{c}$; quart $25 \mathrm{c}$; peck $\$ 1.50$.

New Early Golden Cluster Wax. Undoubtedly the earliest pole variety. Only about ten days behind the Dwarf Golden Wax. Although it begins to bear early, it continues until frost. Everyone is surprised at its beautiful appearance and productiveness The pods are from six to eight inches long, borne in clusters of from three to six, and most freely produced : stringless, very tender, and of delicious flavor. Pkt. $10 \mathrm{c}$; $1 / 2$ pint $15 \mathrm{c}$; pint $25 \mathrm{c}$; quart $40 \mathrm{c}$; peck $\$ 20$.

Lany Wives Pole Bean. This varlety originated in Bucks county. Pa., where for a number of years it has been the most popular Pole Bean grown. Pods are wonderfully broad, thick, fleshy, and abova all, entirely stringless. In these respects they surpass any other kncwn. Then, again, the pods retain their rich, stringless and tender qualities until they are almost ripe, so much so, in fact, that we are perfectly safe in saying they are the best of all Snap sorts. They also surpass every variety in the way vines cling to the pole, and every bean grower will at once acknowledge this is a most important qualification. The name, we think, implies productiveness, for the vines being covered all summer with masses of beautiful pods, it is just the sort to suit wives, as a mess can soon be picked for dinner, Pods are rather flattish, oval shape, and when fully grown are from four to six inches long, exceedingly rich, buttery. and fine flavored when cooked. They are hardy, easily grown, and enormously productive. We could furnish hundreds of testimonials from persons who have used the Lazy Wives Bean, all claiming it to be the best bean they have ever tried, and many have discarded all other kinds, using this for an early and late snap sort, and also as dry shell or $w$ inter bean ; and such is the peculiar taste and flavor of this bean that we have known many persons who could not be induced to eat other varieties of string beans after tasting Lazy Wives, if they could obtain the latter. Pkt. 10c: pint 20c; quart $30 c$

\section{All Our Beans are Northern Grown,}

and are free of the Bean Weevil. This is a great point in our favor, as of late years this insect has been a great disturber and ruination of many Bean crops.

\section{All prices quoted postage paid on Peas, Beans and} Corn in packets only. $\begin{gathered}1 / 2 \text { pints, pints, Postage Extra. } \\ \text { and quarts. }\end{gathered}$

\section{Read Pages 56 to 62, describing different ROSES, CLEMATIS and Plants we have for sale. Send in your Orders, they will Please you.;}

\section{BEETS-FOR THE TABLE.}

(One ounce sows 60 feet of drill; 4 to $6 \mathrm{lbs}$. for one acre.)

CULTURE. - Sow as early in the Spring as the ground can be worked, and every two weeks after for a succession up to the first week in July. For general crop sow about the middle of May. The soil should be light, well enriched with manure, plowed and harrowed until very fine. Sow in drills one foot to filteen inches apart, and when well up, thin from four to six inches. The young Beets pulled cut of the rows are excellevt used as Spinach.

Cong 8mooth Dark Blood. A good variety of late Beet, sweet and tender; will keep solid and fresh all Winter. Pkt. 5c; oz. $10 \mathrm{c} ; 4$ oz. $15 \mathrm{c} ; 1 \mathrm{lb} .40 \mathrm{c}$. 


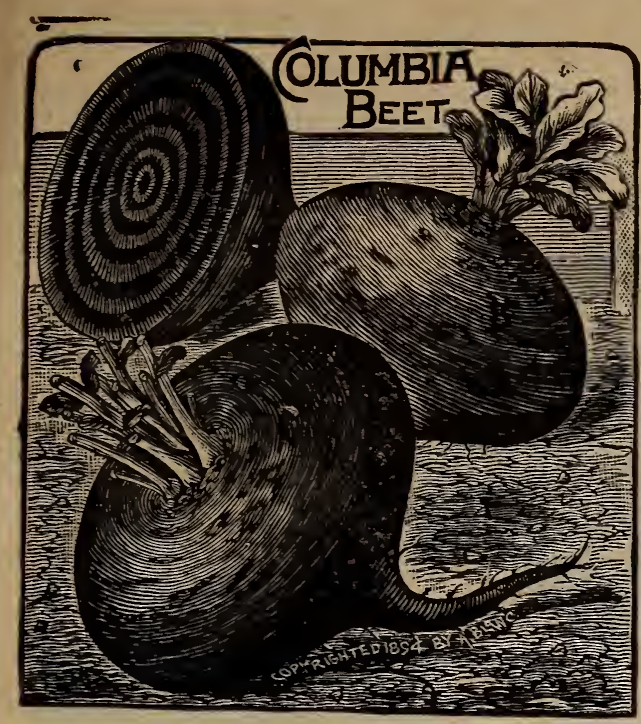

Now Columbia Blood Beet. This is a distinct new Beet of a handsome turnip shape, with smooth skin and deep blood red flesh of finest

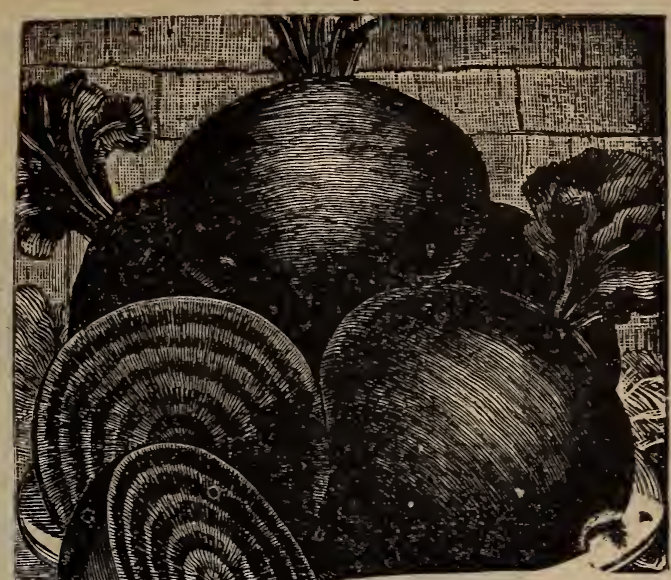

Crosby's Improved Egyptian.

quality Ready to use very early, as soon as the well-known Egyptian, but of better quality It is remarkably thoroughbred. The iops uniformly small, and of a rich, bronzy color. Is not only of unusual value to market gardener, but its tine quality will delight the private planter. (Is a money maker). Pkt. $5 \mathrm{c}$ oz. $10 \mathrm{c} ; 4$ oz. $20 \mathrm{c}$; 1b. $60 \mathrm{c}$.

Crosby's Improved Egyptian. We believe this to be the earliest variety of Beet in existence. It was originated by a leading market gardener for the Boston market, and is a great improvement on the old Egyptian, being ihicker, bandsomer and more regular in shape, smooth, with very small tops and small tap root. It is of perfect shape when small, thus making a good Beet for bunching, and is very popular with the Toledo market gardeners for this purpose. Pkt. $5 \mathrm{c} ; 0 \mathrm{z} .10 \mathrm{c} ; 40 \mathrm{z} .20 \mathrm{c} ; 1 \mathrm{~b}$. $50 \mathrm{c}$.

Lentz Blood Turnip. This variety originated with one of the largest market gardener (in Philadelphia It is as early as the Egy ptian, but larger, of fiue dark red color, a very small top, tender and sweet. It is very productive and a good keeper. Pkt. 5c; oz. 10c; 4 oz. 20c; 1b. 50 c.

Ldmand's Early Blood Turnip. Ove of the best Beets grown, being a very careful selection. The roots are of good form, round, with only one single small tap root; the flesh is of a deep blood red color, and

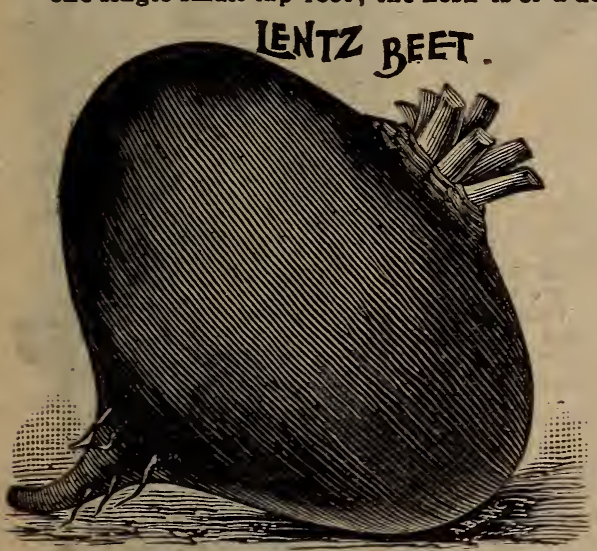
very sweet and ten. der; they can be planted very closely, as they do not grow large and coarse and have a very small top It is one of the best. for the market gard. ener and for table use. Pkt $5 \mathrm{c} ;$ oz. $10 \mathrm{c} ; 1 / 4 \mathrm{lb}$. $20 \mathrm{c}$; $1 \mathrm{~b}$ 50c.

We stand back of every claim made in our catalogue and we want your trade. Our policy is good Seeds, full measure, a living for you and one for ourselves.

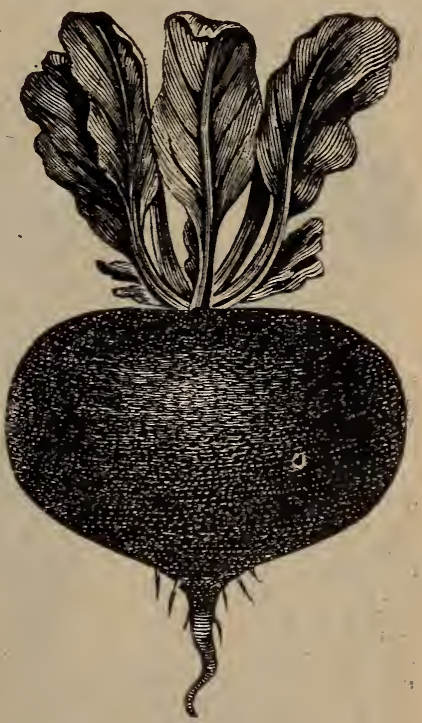

EDMAND'S NEW BLOOD BEEZ

Eclipse. A very early, smooth, dark, globe-shaped Beet, with small top; in earliness and quality it is excelled by none. A good cropper. We can recommend it highly for market and garden use. Pkt. $5 c ; 0 z .10 c$ :
$40 z .15 \mathrm{c}$; lb. $50 \mathrm{c}$.

Early Blood-Red Turnip. The old stand-by and a universal favorite. late. Pkt. $5 \mathrm{c}$; 0z. $10 \mathrm{c} ; 4$ oz. $15 \mathrm{c} ; 1 \mathrm{~b} .50 \mathrm{c}$.

Deep blood color. Good early and

Now Half-Long Blood. This is an entirely new and distinct variety, by far the best for Summer and winter use. The roots are only balf as long as the L,ong Blood. but weigh as much on account of their thickness never becoming woody even in the exposed portions. Pkt, $5 c$ red flesh is very sweet, crisp and tender 
Improved Carly Eeyptian The standard early market sort; color very deep red; tender and sweet; in form like the Flat Dutch Turnip Our seed is a special selection of the darkest, earliest and most perfect roots $\mathbf{F}$ ith small tops. Pkt. $5 \mathrm{c} ;$ oz. $10 \mathrm{c} ; 4 \mathrm{oz} .15 \mathrm{c} ; 1 \mathrm{~b} .50 \mathrm{c}$.

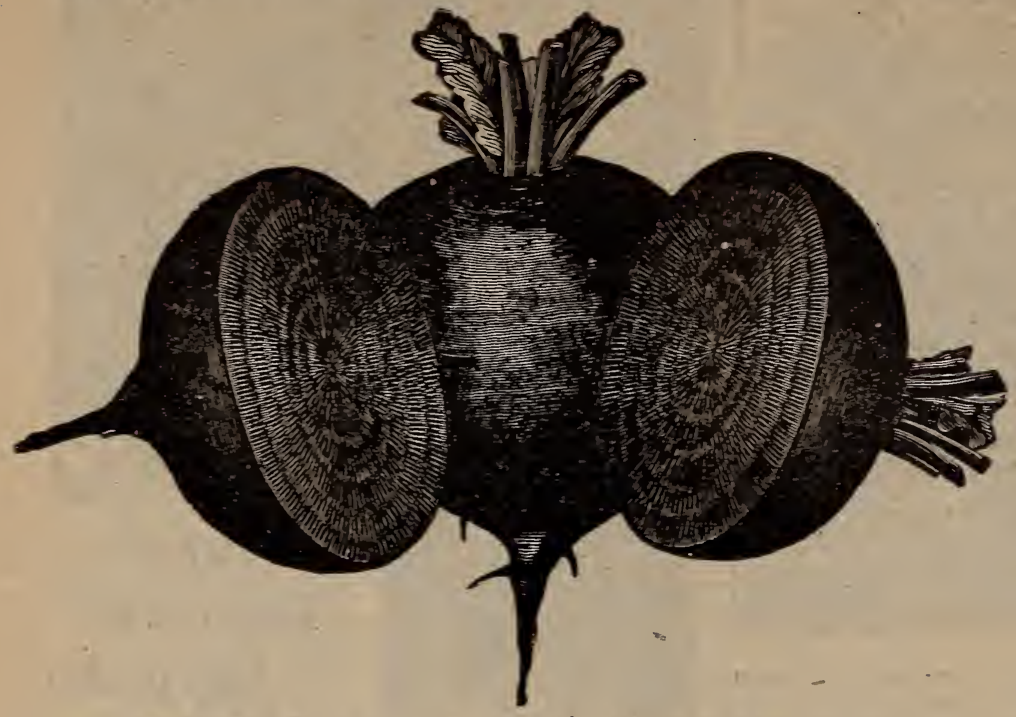

Improved Arlington, or Rawson's Boston Market Beet. A great favorite, of medium size and a dark, rich, bloodred color. One of the strongest points in favor of this variety is the fact that it does not get bitter and stringy when it is a little old, as is the case with many other varieties, but is sweet and tender at all times. Its grand quality, uniform shape and beautiful color leave nothing to be desircd in this grand Beet. Pkt. $5 \mathrm{c}$; oz. $10 c ; 1 / 41 b .15 c ; 1 b$. $6 l c$

IMPROVED ARLINGTON, OR RAWSON'S BOSTON MARKET BEET.

Swiss Chard, Surer or Sea-Kale Beet.

Cultivated for its leaves, which are used similar to Spir ach. The midribs are stewed like asparagus. Pkt $5 \mathrm{c} ;$ or. $10 \mathrm{c} ; 40 \mathrm{oz} .15 \mathrm{c} ; 1 \mathrm{~b} .5 \mathrm{dc}$.

\section{SUGAR BEETS AND MANGEL WURZEL.}

\section{SUGAR YARIETIES.}

The Sugar Beet industry in this country is growing each year. and 6 rst quality seed will be in demand. We import our Sugar Beet seed direct from Germany and France so that our customers can depend upon getıing first-class seed at rock bottom prices. Sugar Beets are nct so heavy croppers as Mangels, but are of superior quality, containing a large a mount of saccharine matter.

No crop will pay the farmer better than Mangel Wurzel and Sugar Beet. Special price given on application for larger quantities of any kind Mangels and Beets.

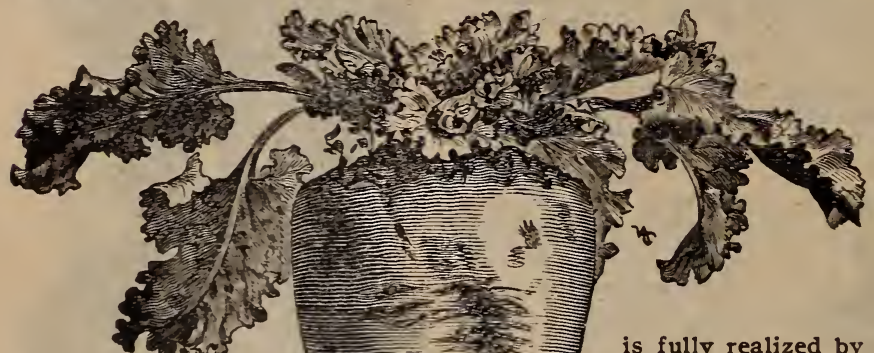

From five "to six pounds of seed $1 \mathrm{e}$ quired to the acre. Write for estimates on larger quantities.

The attention of farmers to the grow. ing of roots for teed. ing stock bas increes ed rapidly, judging from the increased sales of our selected seer's, which now reach several tons annually. The wonder ful results are plainly shown in the bealth and general condition of the animal, and in the increased yield of milk in cow 8

The importance and value of this crop to farmers cannot be over estimated, and is fully realized by very few, when the fact is considered that as high as fifts tons of Mangel Wurzel may be grown on a single acre, thus providing fresh and healthful stock food for the Winter at so small an outlay.

CULTURE - The seed should be sown from April to middle of June. in drills two fet $t$ apart, and afterxards thinned out to sta nd nine inches apart in the rows. Beep well cultivated and you will bave an abundant crop of roots for Winter use. The plants can also be replanted like Cabbage. -

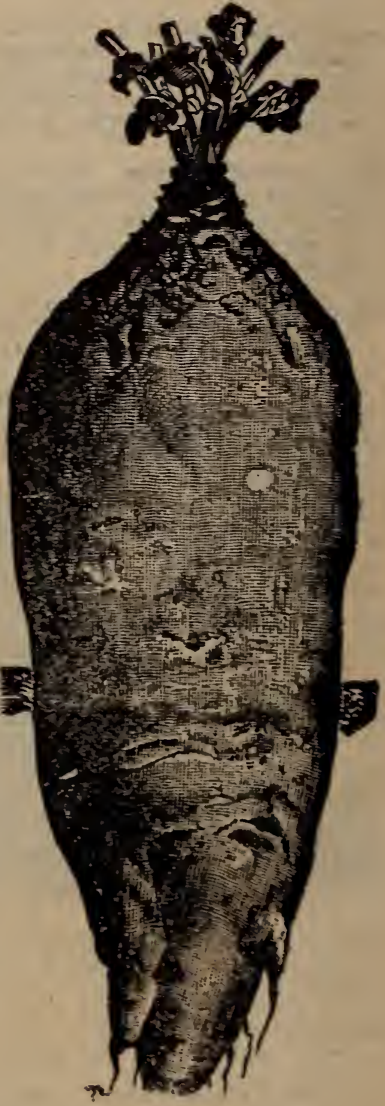

Beet. Grows large and useful for sugar, as well as stock feeding, Pkt. $5 c$; 2 oz. $10 \mathrm{c}$; $1 / 2$ io. $15 \mathrm{c}$; lb. $30 \mathrm{c}$ !
MAMMOTE LONG RED MANGEL WURZBL. 
Gloin-Wanzleben. This kind is cultivated on a larger scale than any of her Sugar Beet. The root is conical, straight and even, quite large at the head and rapidly tapering. It is a heavy yielder, and contains 13 to 15 per cent. of sugar. Pkt. $6 \mathrm{c} ; 202.10 \mathrm{c} ; 1 / 21 \mathrm{~b} .15 \mathrm{c} ; 1 \mathrm{~b} 30 \mathrm{c}$.

Cano's Improved Imperial Sugar Beet. An improvement on the French Sugar Beet. The most popular, profitable and productive variety of Sugar Beet 2 in cultivation. For feeding cattle, sheep and swine it has no equal. This Beet will yield from 30 to 40 tons per acre, at a cost of $5 \mathrm{c}$ per bushel. It is the result of many years' improvem. ni, by carefully selecting and planting for several years the finest * pecimens of the French Im perial Sugar Beet. It is one of the best adapted to the soll and clima e of the United States, and most valuable of any for stock feeding purposes. The Beets grow to a large size, and perfect in shape. Very free from side roots, easily grown and excellent keepers. We recommend L,ane's Imperial Sugar to our friends and customers who anticipate growing Beets for feeding purposes, as it is certalnly one of the most profitable and valuable kinds. PKt. $5 \mathrm{c} ; 20 \mathrm{z} .10 \mathrm{c} ; 1 / 21 \mathrm{~b} .15 \mathrm{c} ; 1 \mathrm{~b} .30 \mathrm{c}$.

\section{STOCK FEEDING VARIETIES.}

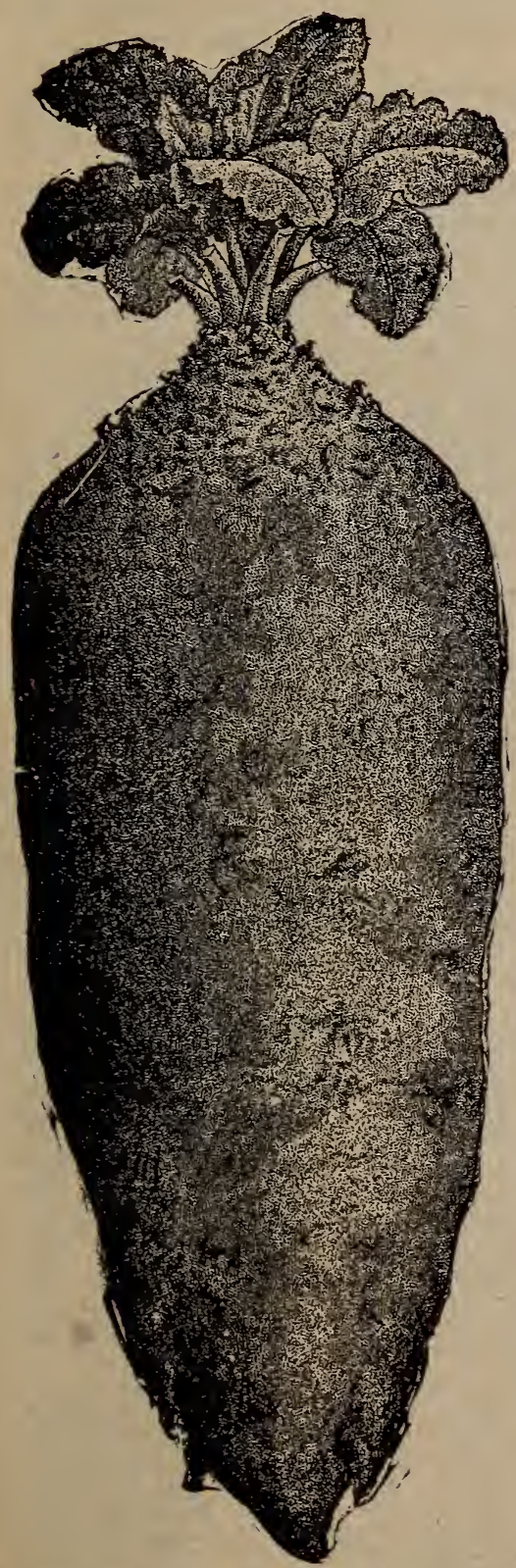

NOKBITOX GIANT, OR JUMBO RED MANGEL.
Mammoth Long Red Mangel Wurzel. Very large and pre ductive. Pkt. $5 \mathrm{c} ; 2$ oz. 10c: $1 / 21 \mathrm{~b}$. 15c;1b. 30c.

Norbiton Giant, or Jumbo Red Mangel. Stands head above all other varieties of Mangels : unequalled for yielding and feeding qualities Thousands of farmers have grown this Mangel and call it the most profitable farm crop they ever tried. If you want a large crop of large Mangels of good quality don,t fail to try the Norbiton Giant or Jumbo Red Mange; enormous cropper Preferred by many to common Long Red, as its keeping quality is considered better and it is much larger. Pkt. $5 \mathrm{c} ; 2 \mathrm{oz}$. 10 ; $1 / 2$ lb. 15c; 1b. 30c.

Golden Tankard Yellow. Fleshed Mangel. This distinct variety is a most important addition to our list of roots for stuck feeding, as it contains less water and more sugar than any other Mangel. A special feature is the rich, deep yellow color of the flesh nutritious and milk producing qualities. In England, where it is considered indispensab.e for darry farming. large dairy farmers state that they are not only able to obtain a higher price per gallon for milk from cows fed on this mangel, but also that the cows are in much better condition. Is exceedingly hirdy, and maturing earlier than other large sorts Pkt. $5 \mathrm{c} ; 2$ oz. $10 \mathrm{c} ; 1 / 2 \mathrm{lb}$. $15 \mathrm{c} ; 1 \mathrm{~b} .30 \mathrm{c}$.

Champinn Yellow Globe Mangel Wurzel. For cattle; large and productive; keeps well : is of orange yellow color : very sugary ; easily pulied. Pkt. $5 \mathrm{c} ; 2$ oz. $10 \mathrm{c} ; 1 / 2 \mathrm{lb} .15 \mathrm{c} ; 1 \mathrm{~b} .30 \mathrm{c}$. Growing Mangel Wurzel and Sugar Beet for stock is the growers best investment. These make the cheapest of foid for all kinds of live stock, Caitle, Horses, Sheep, Pig, Chick ens. Two bushels of Mangels are worth as much as one bushel of Corn. Four bushels of Mangels are equal to $100 \mathrm{lbs}$. of good hay. It is pleasing to receive scores of the most flattering reports from our friends of their great crops of Mangles giown from the seed they bought of us. Ous friends may rely upongetting the best seed, grown from the choirest strain and stock in the world. Send us your order.

Read page 24 for seed Collections.

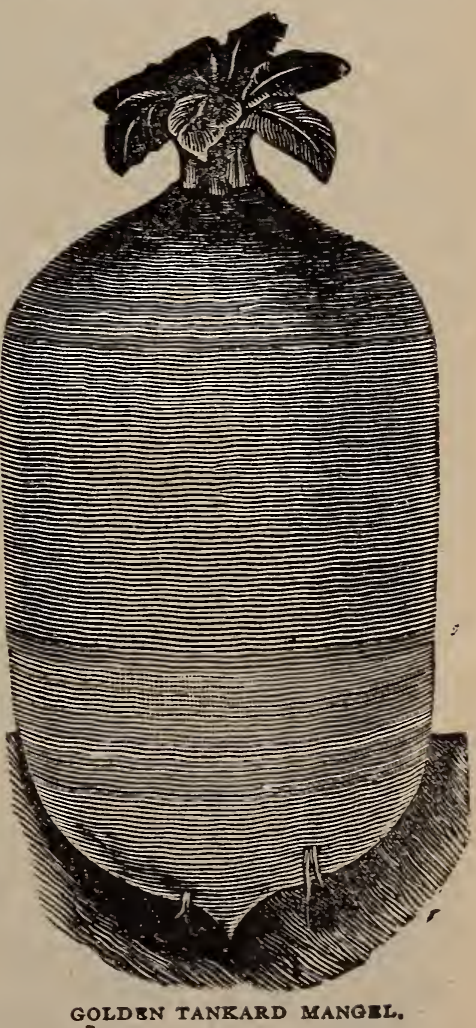

BROCCOLI.

CULTURE.-Same as Cauliflower. This very much resembles Caulifower in appearahce and uses, but is by many considered more delicate,

Broccolt. Large White Mammoth Cape, produces fine large heads and are equal in size and quality to the best and largest varieties of Caullilower.,,$P k t .5 c ; 0 z .25 c$; 


\title{
BRUSSELS SPROUTS.
}

CULTURE.-Same as Winter Cabbage. This is a delicious vegetable of fine flavor, allied to the Cabbage family, producing great numbers of small heads or sprouts on the main stem of the plant, which sre used in the manner of Cabbage. Used and prepared as greens, they are the best in the Autumn, especially after frost. Pkt. $5 \mathrm{c}$; 0z. $15 \mathrm{c} ; 1 / 41 \mathrm{~b} .35 \mathrm{c}$.

\section{Reliable Cabbage Seeds.}

(SHORT CROP AGAIN THIS YEAR)

\section{SELECTED AMERICAN GROWN STOCKS THAT MARKET GARDENERS CAN DEPEND UPON.}

\author{
WE ARE HEADQUARTERS FOR SELECT AND DOUBLE TESTED SEED.
}

To Market Gardeners generally no vegetable is of greater importance than the Cabbage, and to many growers the success or failure of thi 3 crop means gain or loss for the year. It does not pay, 1 herefore, to take any risk in buying seed. Much of the seed commonly sold has not had the great care necessary in growing to make it reliable.

Our Cabbage Seed is high grade and reliab'e, because it is sure to head under any circumstances where Cabbage will head. Sure to head because the seed is all carefully grown from selected heads of the very best strains. Our trade increases largely every year among Market Gardeners and Iarge growers, who are very cautious of whom they procure their Cabbage Seed and well they may be for it is their most important crop. We especially recommend our Select Very Early Jersey Wakefiela, a variety of celebrity for the first early: Henderson's Early Summer, Philipps' Improved Succession, Fottler's Improved Brunswick, Early Winning. stadt, our Market Gardener's Large Late Flat Dutch, Philipps' Premium Flat Dutch All Seasons, Sure Head. Flat Dutch. Philipps' All Head and Autumn King, for general crop.

Our Cabbage Seed is the best that is grown in tre United States. We do not touch any cheap seed. Ima ported Cabbage Seed, of the late sorts esdecially, will not head in this country.

One ounce ol seed produces 1500 to 2.000 plants and sows an area of about 40 square feet.

CULTURE.- Soil for Cabbage should be rich and heavy loam, with good drainage.

Of the early varietles of Cabbage, in latitudes where the thermometer never indicates 20 degrees below the freezing point, seed may be sown in the open border in October, and transplanted on the first opening of Spring. but in our Northern States they must either be sown in hot beds in February or wintered over in cold frames; for this purpose the seed is sown from the 10 th to the 20 th of September. Attention to date is important; if too soon the plants may run to seed, and if too late they would be too small. . In four or five weeks irom the time of so ring they will be fit to transplant into the cold frames. In planting it is very important with Cabbage or Cauliflower that the plant is set down to the first leaf, so that the stem is all under ground for, if exposed it will be split by the action of the frost, and will be injured in consequence. The plants are usually set out from the middle of March to ihe middle of April in rows about two feet apart, and eighteen inches between the plants in rows. This earliest crop matures in June. For second early the early kinds should be sown first week in April and planted out in May. This crop should mature in July and iAugust. The late varieties are usually so $\pi n$ in the early part of May and the plants are set in July at a distance of three feet between the rows, and two feet between the plants. This crop matures September, October and November.

For Cabbage Worm Try SLUG SHOT.

Read page 76 for description of SIUG SHOT.

\section{FIRST EARLY.}

Select Early Jersey Wakefield. Certainly deserving of its great popularity, and is grown for market moreextensively than any other early Cabbage. It heads up remarkably hard and solid: the heads are pvramidal in shape, generally pointed at the end, and haviug few outside leaves. The plants can be close

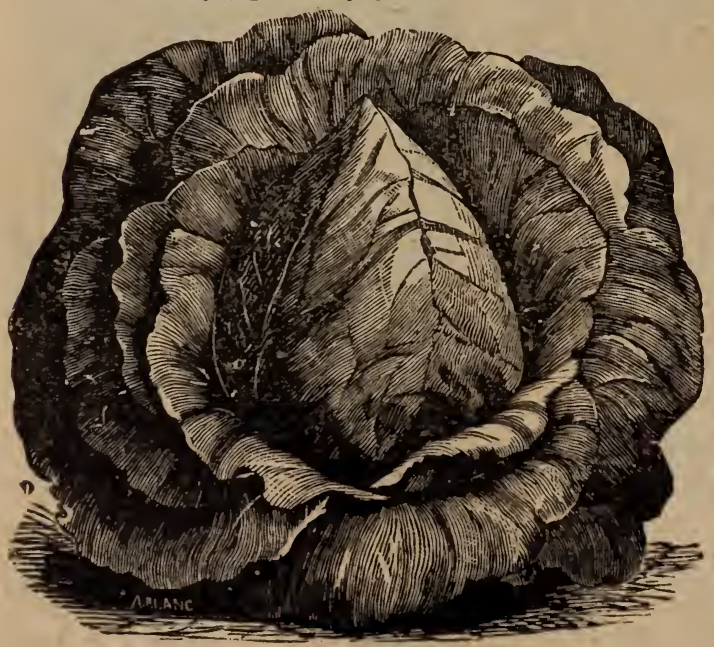

SELECT KXTRA RARLT JERSEY WAKEFIKLD. together. The hesds are of excellent quality and good size. Pkt. 5c; oz. 20c; $1 / 41 \mathrm{~b}$. $5 \mathrm{sc}$ : lb. $\$ 250$.

The Charleston or Large Wakefield Cabbage. It is five to six days later than early Jersey Wakefield. The heads are tully onehalf larger and quite solid It is very compact in growth and can be easily planted in rows two teet apart and twenty inches in the rows. One great advantage is it does not burst open when ripe, like many other early sorts, and consequently can be left standing on the ground a long while without injury until a tavorable opportunity for cutting. Pkt. $5 \mathrm{C}$ : oz. $20 \mathrm{c} ; 1 / 4 \mathrm{lb}$. 75c; $1 \mathrm{~b}$. $\$ 2.50 .1$

Early Winningstadt or Cone. An old standard variety; heads of a fair size, conical in shape, very solid; good for early and late. Pkt. 5c; oz. $15 \mathrm{c}$; $1 / 2$ 1b. $40 \mathrm{c}$; 1b. $\$ 1.25 .1$

Early Summer. The standard for second early. We have an excellent strain of this well known sort. Plt. $5 c$; oz. $15 \mathrm{c} ; / / 41 \mathrm{lb}, 50 \mathrm{c} ; 1 \mathrm{~b} . \$ 1.75$.

Fottler's Early Drumhead or Short Stem Brunswick. A rapid grower, has large solid head and $f e w$ outside leav s. If planted early it is ready for use in July or August; planted late it is a cholce winter sort. Pkt. $5 c ; 0 z .15 c$; $1 / / 1 \mathrm{lb} .50 \mathrm{c} ; 1 \mathrm{~b} . \$ 1.75$. 


\section{SECOND EARLY.}

Genuine Sure Head. This popular Cabbage is rightly named Sure Head. It never fails to make a remarkably fine, solid, large head, with few outer leaves. It originated some years since with a practical market gardener, by crossing the Flat Dutch and Drum head varieties, and has always brought the highest price in mark ets. It is a strong vigorous grower, ripening late for a main crop, and very uniform in size and color. Our supp'y is grown from the original seed, and none better is to be had at any price. Pkt. 5c; oz. 15c: $1 / 41 \mathrm{~b} .50 \mathrm{c} ; 1 \mathrm{~b} . \$ 1.75$.

All Seasons. This strain of Early Drumhead Cabbage we offered to the public some years since, under the broad claim of being about as early as the Farly Summer, and growing much larger. Gardeners everywhere say they find our claims are fully substantiated in every particular. As its name indicates it can be planted at all seasons. It forms a fine large head of superior quality, not bursting after heading; the heads are of great thickness, which makes a capital market sort and good keeper. Pkt. $5 \mathrm{c} ; 0 \mathrm{z} .15 \mathrm{c} ; 3 / 4 \mathrm{~b}$. $50 \mathrm{c} ; 1 \mathrm{~b} . \$ 1.75$.

You cannot miss buying any variety of our CABBAGE SEED. It is all of the highest grade. fresh however that if cent packets for $\$ 1.00$, postpaid.

Read Discounts on page 2. We sell Seeds Cheap. All New stock.

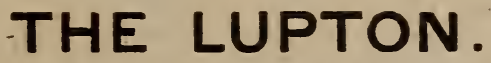

THE GREATEST CABBAGE EVER OFFERED IN THIS COUNTRY

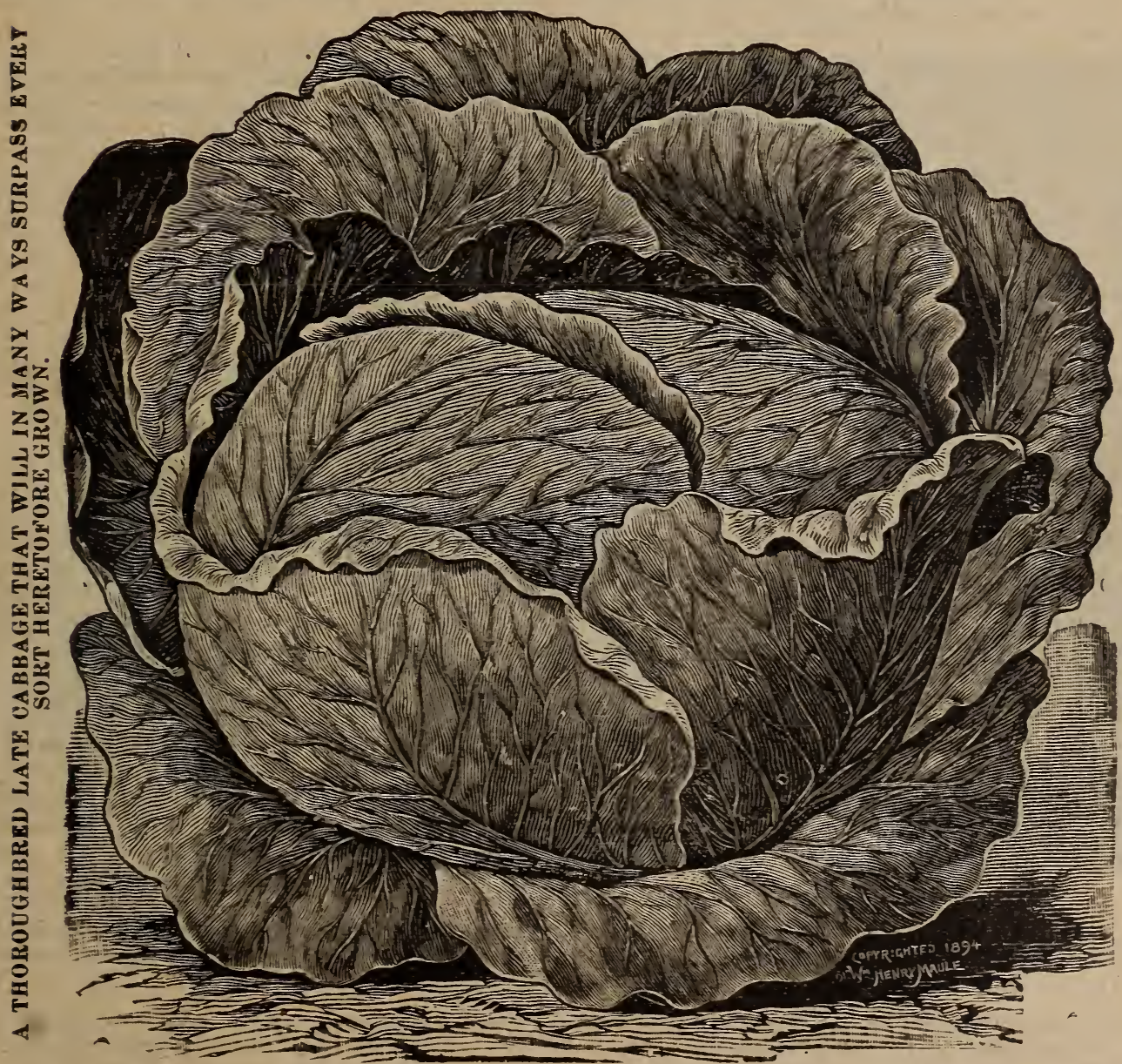

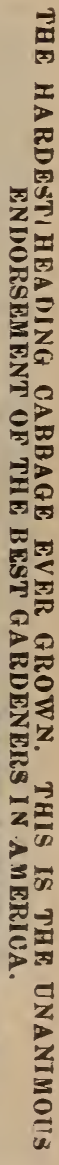

This famous Cabbage was bred and introduced by Mr. Lupton, who is probab!y the largest individual producer of Cabbage Seed in the world. It was bred from a single early plant of a late variety; is earlier than any of the late sorts, much more uniform in growth, heads more evenly, is of better quality, is not quite so large ; can be planted closer, and will give a crop in weight larger than any of them. The heads are unusually deep, similar to the Hollander or Danish. It is a strong, but not a coarse grower; dark groen in color, and fine grained; a good keeper. Intended for a market gardener's main crop Cabbage. Price, pkt. 5c; 0z. $20 \mathrm{c} ; 4$ oz. 60c; 1 lb. \$2.00. 


\section{Hollander or Danish Ball Head Cabbage.}

For several years past all the large cities in the United States have been furnished with Cabbage shipped in from Holland. This Cabbage, although of medium size, weighs about twice what our native grown Cabbage does, and therefore easier to handle when selling by the ton. In order to stop this importation and keep our money at home, we imported the finest strain of this Cabbage grown, and now offer this seed to our gardener friends and patrons. The heads are of medium size heavy and solid as a cannon ball, and will keep over winter much better than our old standard varieties of Cabbage. Give it a trial. Pkt. $5 \mathrm{c} ; 0 \mathrm{oz} .25 \mathrm{c}$; 4 oz. $75 \mathrm{c} ; 1 \mathrm{~b} . \$ 250$.

Philipps' Improved 8uccession Cabbage. This new Cabbage we offer is the best Long Island seed grown from the center shoots of carefully selected solid heads of the very best strain. The Succession is about one week later than the Early Summer, but is double the size and is so finely bred that in a field of ten acres every head was a magnificent. perfect specimen,

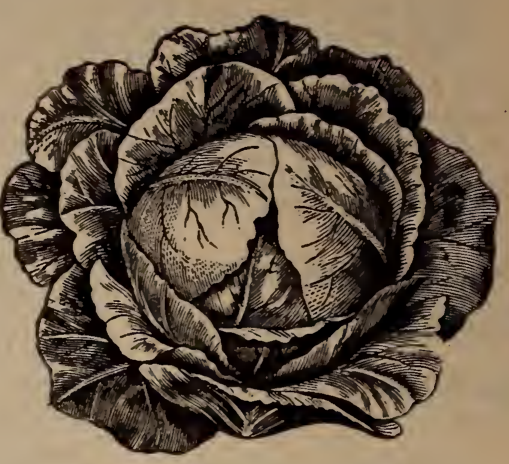

DANISH BALL HEAD CABBAGE. fit for exhibition purposes. The Succession brings paying prices wherever grown, and may be regarded a boon to the gardening community. Pkt. $5 \mathrm{c} ; 0 \mathrm{z} .15 \mathrm{c} ; 1 / 4 \mathrm{lb} .50 \mathrm{c} ; 1 \mathrm{~b} . \$ 1.75$.

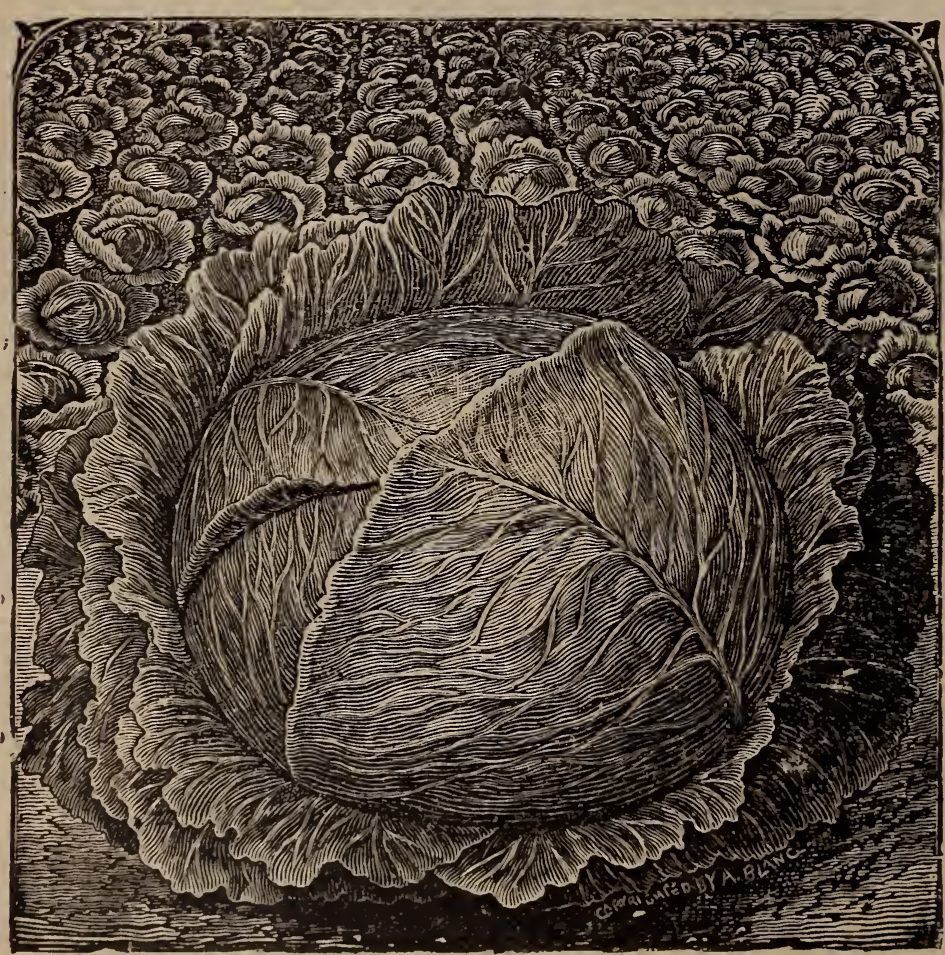

PHILIPPS' IMPROVED SUCCESBION CABBAGE.

Philipps' All Head Mcdium Early Cabbage. It is the earliest of all largo Cabbages. Is fully onethird larger than Early Summer. The deep, flat heads are remarksbly solid and uniform in color as well as in shape and size. Is of fine quality. By reason of the compact habit of growth of the Philipps' All Head Medium Early and the absence of loose leaves, fully one thousand more heads can be obtained to the ac e than of most other varieties of good size. Set the plants eighteen inches apart in the rows with three feet betwren the rows for cultivation, and Nine Thousand Six Hundred and Eighty $(9,680)$ plants can be set on one acre, ninety-five per cent. of which, in an ordinary season and with good cultivation, will make good merchantable heads. "All Head" is all that can be desired for earliness; it is also valuable for a late or Winter Cabbage. To winter well the heads must be deep or thick through-a prominent feature of this variety. Seed of the "All Head," sown in July, and plants set out about the middle ot August, will bring heads large and solid. which are sure to winter well. Pkt. $5 \mathrm{c}$; oz. $15 \mathrm{c} ; \mathrm{y} / \mathrm{1b}$. 50c; $1 \mathrm{~b} . \$ 1.75$.

Early Dwarf Flat Dutch. An excellent second early old standard variety. producing fine large'heads after the first early varieties have disappeared. Highly valuable both for its fine quality and abllity to resist heat. Heads are very solid, broad and round, flattened on top, tender and fine grained. Pkt. 5c; oz. 15c ; 3/4 1b. 50c; 1b. $\$ 1.75$.

Improved Stone Mason, or The Warren. We think this is one of the very best for Fall and Winter use. Our stock is of the best. Plant medium sized, with only a moderate number of leaves; stem medium length; head medium sized to large, rcund or slightly flatened, ve $y$ solid, crisp, tender, without being coarse or strong flavored. It will certainly give the greatest satisfaction. Pkt. $5 \mathrm{c} ; 0 \mathrm{z}, 20 \mathrm{c} ; 2 \mathrm{oz}, 35 \mathrm{c} ; 3 / 4 \mathrm{lb}$. $60 \mathrm{c} ; .1 \mathrm{~b} . \$ 2.00$. 


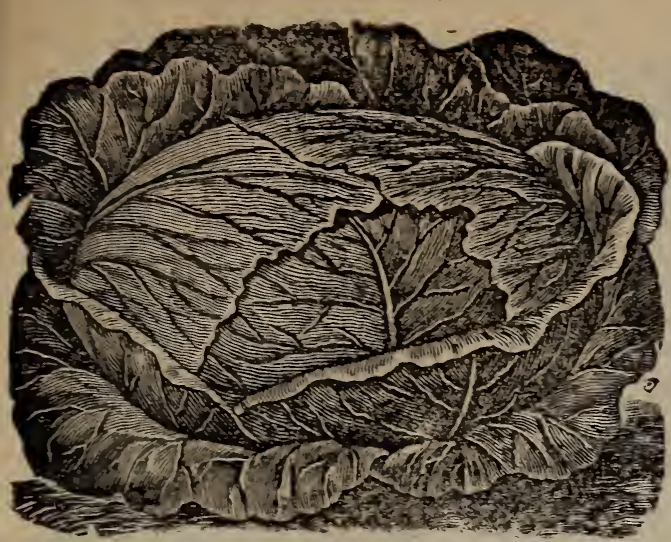

Philipps' Preminm Large Late Flat Dutch. As a variety for the main croo and the Winter market this has n? superior. Heads large. round, solid; broad, and flat on the top; they open white and crisp, are tender and well flavored It is also one of the very best varieties to keep. Pkt. $5 \mathrm{c} ; 0 \mathrm{z} .15 \mathrm{c} ; \mathrm{K} / \mathrm{lb}$. $50 \mathrm{c} ; 1 \mathrm{~b} . \$ 1.50$.

Toledo Market Gardeners' Large Late Flat Dutch. This strain of Cabbage has worked itself to the front and enormous crops a re grown every season around Toledo, and we honestly recommend this strain of Cabbage to all who wish to grow a large, heavp. hard, smooth-leaved, late ripening Cabbaz; no strain is superior, and few equal to this. The leaves are feathered to the stock, slightly fluted or twisted on the outer edges. Color, a clear green with a gray or ashy shade under certain lights. The head is thick, hroad, solid and slightly rounded on the top, though the variety is $w^{\prime}$ at is termed the flat head. The natural habit of the seeding plants is to develop thick. short stocky stems The seed is worth twice the money asked for it. The strain carefully selected to met the most critical demand. To those who have never grown this splendid type of Cabbage, will say PHILIPPS' PREMIUM LARGE LATE FLAT DUTCH. never grown this splendid type of Cabbage, will say testimonials about it. All give it the highest praise. and we recommend it to our friends as one of the $e_{\infty}$ best and nost productive Winter Cabbages in the country. Pkt. $5 \mathrm{c} ; 0 \mathrm{z} 15 \mathrm{c} ; 1 / 4 \mathrm{lb} .60 \mathrm{c} ; 1 \mathrm{~b} . \$ 2.00$.

Do not fail to send us your order for one or more of our Lightning Sprayers made in two different styles, in Tin or Brass, at 60 cents and $\$ 1.25$ each. These are the best liquid sprayers made for House, Garden, Orchard or Potato field use. (See page 78. )

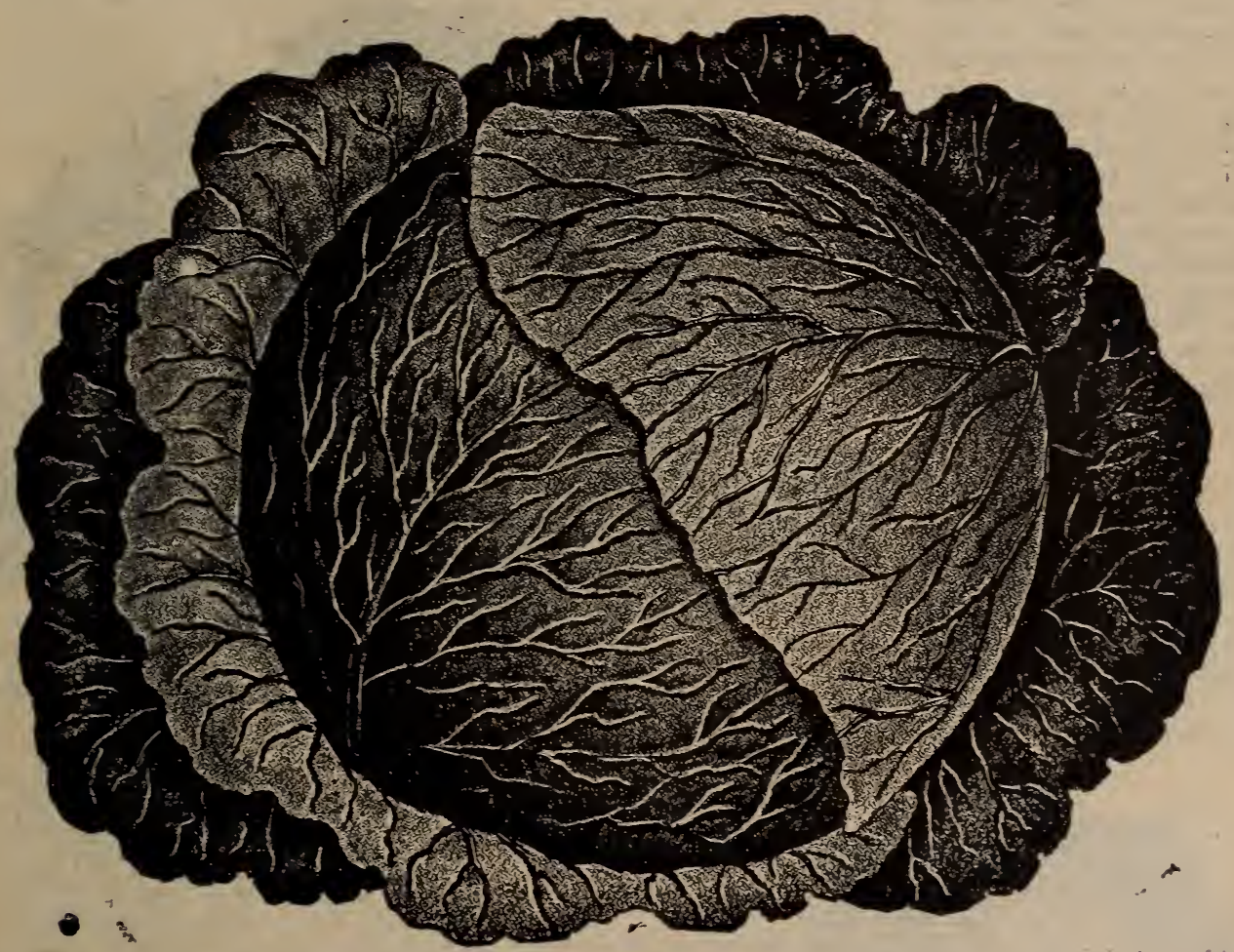

OUR TOLEDO MARKET GARDENERS' LARGE LATE FLAT DUTCH.

(Specially grown for us on Long Island.) Market Gardeners ! In fact, all who grow Cabbage for market or private use, don't fail to try our Market Ga.deners. We have our Cabbage Seed grown by the most reputable, honorable and experienced Cabbage Seed Growers on Long Island. We get our seed direct from the grower, and not second-handed. We pay a good price for it, as good seed costs money, and then it is cheap. We make special prices to Market Gardeners and large growers. Don't fail to give us your order, as it is to your own benefit to do so. 


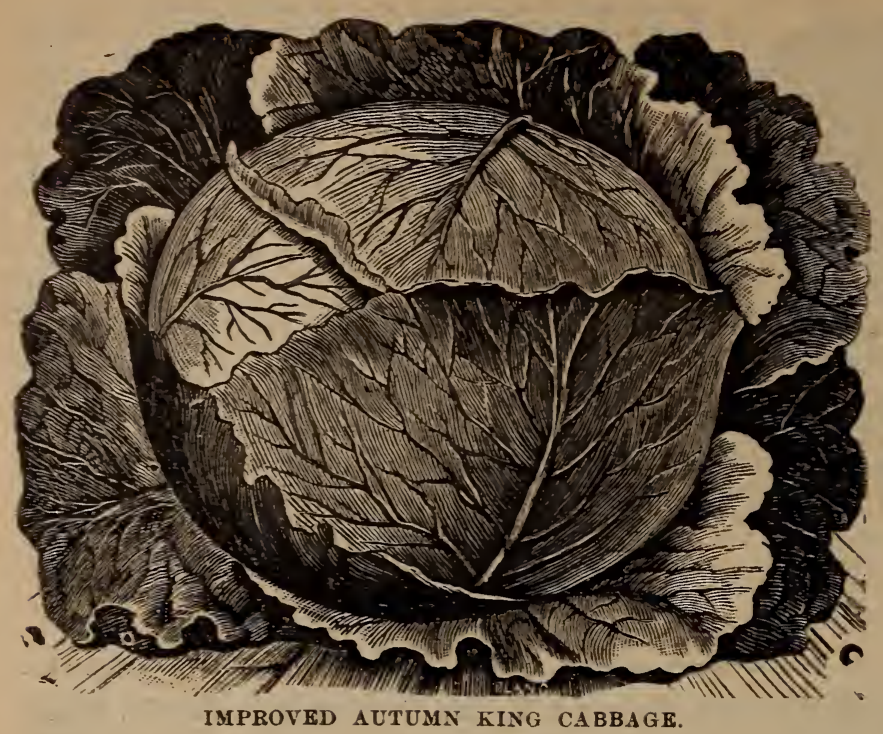

IMPROVED AUTUMN KING CABBAGE.

Improved Antomn King Cabbage. Has proved itself a peerless variety and is coming into general use. We have no hesitation in recommending it as one of the finest late Cabbages in this country. The Autumn $\mathrm{King}$ is an entirely distinct variety and the best keeper ever seen; it produces enormous solid heads of that dark shade of green that is most desirable in a Cabbage, and has such small outer leaves that it can be planted much closer than the ordinary late sorts, and can be relied upon to produce a greater weight of crop per acre from the fact of its producing so few outer leaves and going all to head. We understand that some other seedsmen are offering this same stock of Cabbage under the name of "World Beater," which variety was introduced a few years later as one of the grandest of all winter Cabbages, which is the case

with the Autumn King. Pkt. $5 \mathrm{c} ; 02.15 \mathrm{c} ; 1 / 4 \mathrm{lb} .50 \mathrm{c} ; \mathrm{lb} . \$ 1.75$.

\section{Philipps' Toledo Large}

Late Drumhead. This is one of our standard late maturing varieties. L,arge, solid bead, with very short stem : grows very compact1y. Heads frequently attain 20 to 30 pounds. We highly recommend this great $\mathrm{Cab}$ bage to all : always reliable as a header and noted for its excellent quality. Pkt. $5 \mathrm{c}$. : oz. $15 \mathrm{c}$; 1 lb. $50 \mathrm{c}$; $1 \mathrm{~b} . \$ 00$,

PHILIPPS' RELIABLE SATOY OR CURLED CABBAGE.

We desire to call special attention to this class. All of the varieties enumerated below being of much finer flavor and quality than the best of other Cabbages. They are particularly adapted for

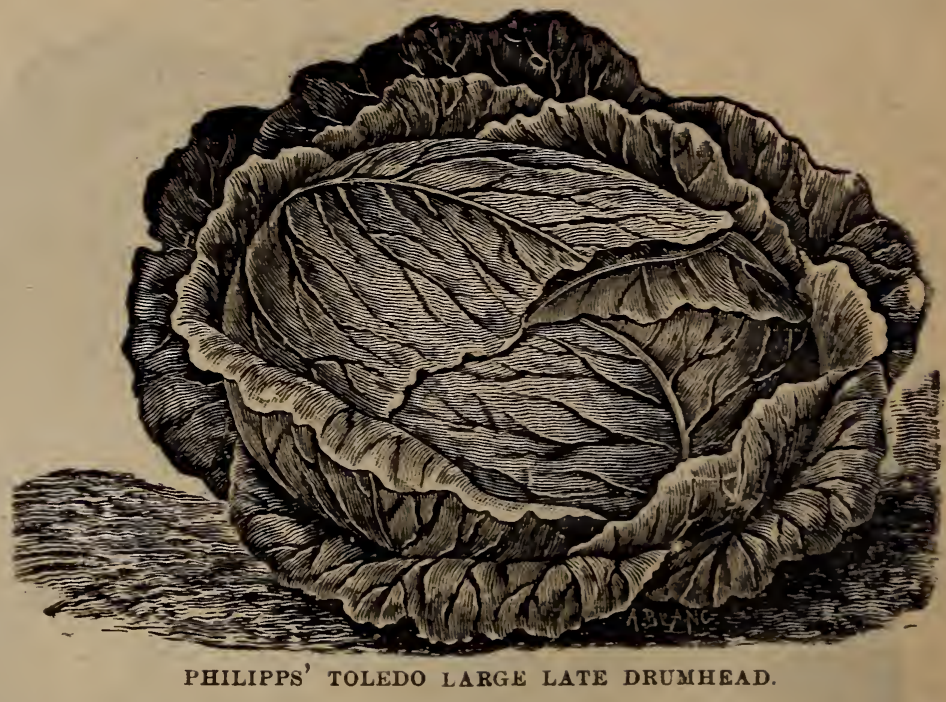

private use, where qualiły rather than quantity is desired. Grown in the Fall and allowed to be touched by fros', it is one of the most delicious of all vegetables.

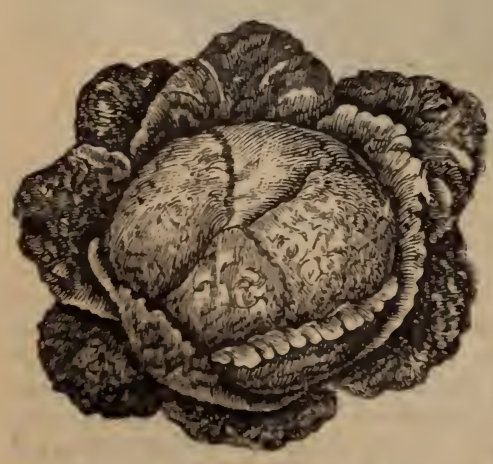

AMERICAN DRUMHEAD SAVOY.

Netted Savoy. This is the finest of the Savoy class, and a general favorite. Heads large, very solid and compact, a yellowish-green color, and like all other of the Savoy varieties, is of excellent flavor. far surpassing that of any other late Cabbage. Pkt. $5 \mathrm{c} ; 0 z, 15 \mathrm{C}$; $1 / 4$ lb. 50 c; 1 lb. $\$ 1.75$.

American Drumhead Savoy. The largest heading Savoy; of excellent flavor. Pkt. 5c;0z. 15c; $1 / 41 \mathrm{lb} .50 \mathrm{c} ; 1 \mathrm{~b} . \$ 1.75$.

We sell all kinds of BIRD SEED for Canaries and Parrots, so let us know your wants in that line.

See our big $\$ 1.00$ collection on page 2 . 


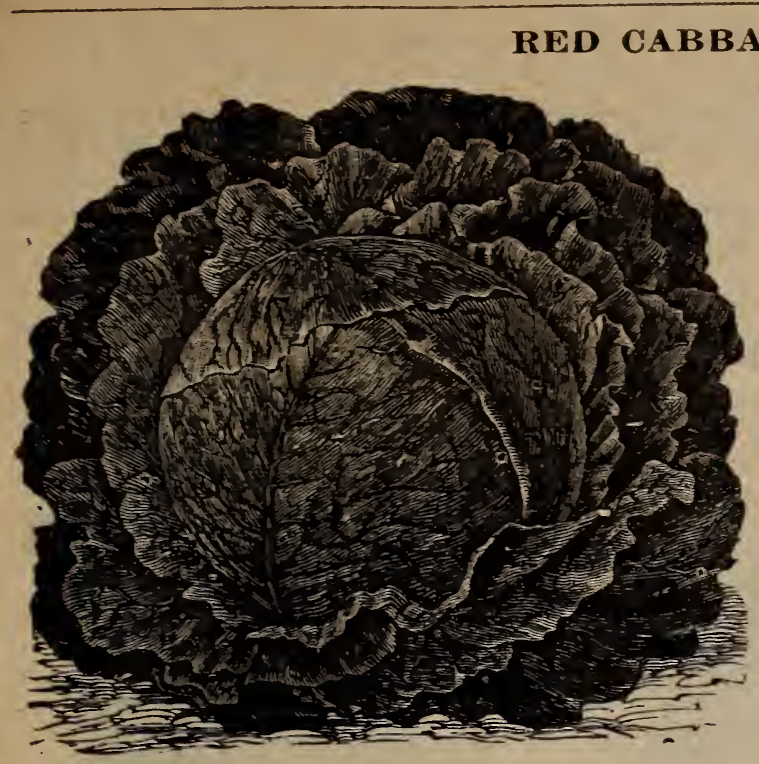

MAMMOTH ROCK RED CABBAGE.

Extra Early Dark Red Erfart. The earliest and finest red. A useful sort for pickling. Pkt. $5 \mathrm{c}$ : oz. $15 \mathrm{c} ; 4$ oz. $50 \mathrm{c} ; 1 \mathrm{~b} . \$ 1.75$.

Mammoth Rock Red. The Mammoth Rock is by far the best, largest and surest heading Red Cabbage ever introduced. The plant is large, the head is large, round, very solid and of deep red color; will average $12 \mathrm{lbs}$. each Pkt. $5 c$; oz. $20 \mathrm{c} ; 4$ oz. $60 \mathrm{c}$; $1 \mathrm{~b} \$ 2.00$.

It was the RED CABBAGE exhibited at the Fairs in our section, from SEED WR SOLD, which drew tbe highest premium. Do not fail to try some.

Much IMPORTED Cabbage Seed is offered as American at low prices. Our experience is that imported seed of the late varieties is worthless.

Plants quoted "by mail," are sent at our expense ; "by express," at the purchaser's.

Cabbage Plants. Any of our early varieties ready A pril 10th. By mail, 100, 75c; by exprees, 100,50c;1,000, $\$ 50$.

Cabbage Plants. Any of our late varieties ready June 1st. By mail, 100, 75 ; by express, $100,40 \mathrm{c} ; 1,000, \$ 00$.

\title{
We can sell our Farmer and Gardener friends just as good Seed as any
}

\begin{abstract}
Seedsman has to offer. Please remember we are Growers and Importers.
\end{abstract} Send us your order and get Seeds true to name. Market Gardeners read page 2.

\section{CARROTS.}

Sow 1 ounce to 150 feet of drill ; 4 lbs. to the acre.

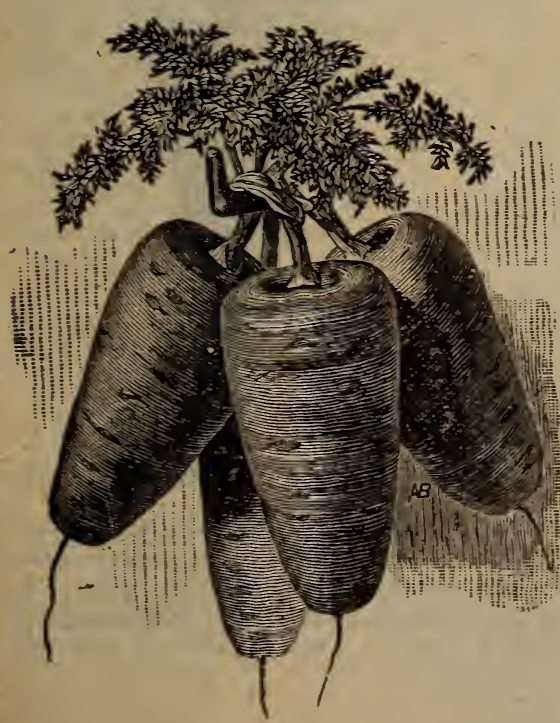

CHANTENAY HALE LONG SCARLET.

CULTURE.-The Carrot, like all other root crops, delights in a sandy loam, richly tilled. For early crops sow in Spring as soon as ground is in good working order; for later crops they may be sown any time until the midd e of June. Sow in rows about fifteen inches apart, thinning out to three or four inches between the plants. In field culture, when grown for horses or catt:e, the rows should be two feet apart, so that the crop can be worked by the horse cultivator. As carrot seed is slow to germinate, all precautions must be taken.

Chantenay Half Long Scarlet. A stump-rooted variety, somewhat resembling the well-known Nantes Carrot, but havirg a larger shoulder and being wuch more productive : sweet, fine flevored, almost without a core; very fine grained; excellent for home garden and market. Pkt. $5 \mathrm{c}$; oz. $10 c ; x / 4$ 1b. $20 c$; 1b. $60 c$.

Early Scarlet Horn. Blunt, deep red flesb, tender and delieate; a good early summer sort. Also good for forcing. Pkt. $5 c$; 0z. $10 c ; 4$ oz. 20c; 1b. 60c.

French Forcing. The earliest forcing variety, globe-shaded, reddish-orange color. Good for bunching. Pkt. $5 \mathrm{c}$; oz. $10 \mathrm{c} ; 1 / 4$ lb. $20 \mathrm{c}$; 1b. $60 \mathrm{c}$.

Read Field Seed Department. 
Atringham. This Carrot is an immense and sure ylelder. Roots are long and large, of a fine scarlet color, good fiavor and superior fee 1 ing qualities. Pkt. $5 \mathrm{c} ; 0 \mathrm{z} .10 \mathrm{c} ; 1 / 4 \mathrm{lb} .20 \mathrm{c} ; 1 \mathrm{~b} .45 \mathrm{c} ; 5 \mathrm{lbs} . \$ 2.00$.

Large White Belgian. Very productive kind, grown almost exclusively for stock; grows one-third out of the ground; lower part of root white; that above ground green. Pkt. 5c;0z. 10c, 1/4 1b. 20c;1b. $45 \mathrm{c} ; 5 \mathrm{lbs}$. $\$ 2.00$.

James' Intermediatel This variety nearest resembles the Danvers (it might be called two-thirds long), but thicker at shoulder and heavier. Pkt. $5 \mathrm{c} ; 0 \mathrm{z} .10 \mathrm{c} ; 1 / 4 \mathrm{lb} .20 \mathrm{c} ; 1 \mathrm{~b} .60 \mathrm{c}$.

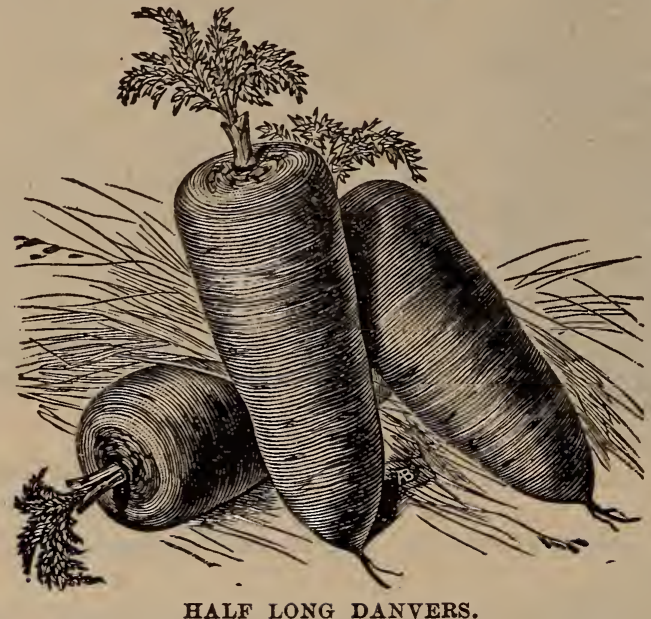

Danvers Half Long Orange. This variety originated where the raising of Carrots is made a special business, twenty to thisty tons per acre being no unusual crop. In form it is midway between the Long Orange and Short Horn. The root is of a rich. dark orange color, and grows very smooth. Pkt. $5 \mathrm{c} ; 0 z .10 \mathrm{c} ; 1 / 4 \mathrm{lb} .20 \mathrm{c} ; 1 \mathrm{~b} .60 \mathrm{c}$.

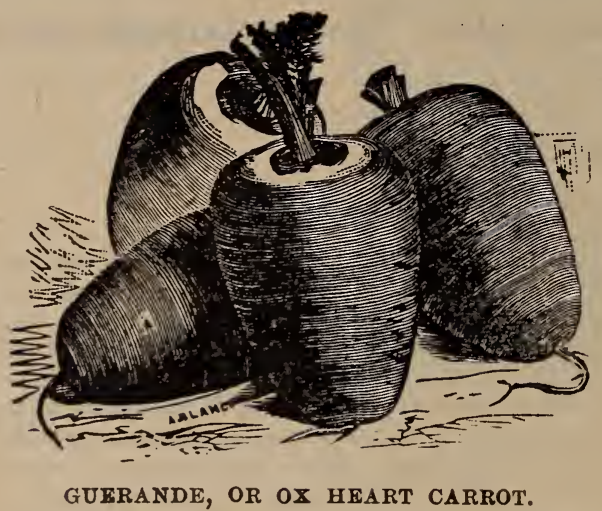

Guerande, or Ox Heart Carrot. A very desirable Carrot. In length intermediate between Short Hoin and Chantenay; much thicker than either, and carries its thickness well down towards the bottom. In color as dark as Chantenay; is an immense cropper, early harvested, requiring no digging, while its handsome appearance and excellent table qualities make it valuable for either the market or home garden. Pkt. $5 \mathrm{c} ; 0 z .10 \mathrm{c} ; 1 / 4$ lb. $20 \mathrm{c} ; 1 \mathrm{~b}, 60 \mathrm{c}$.

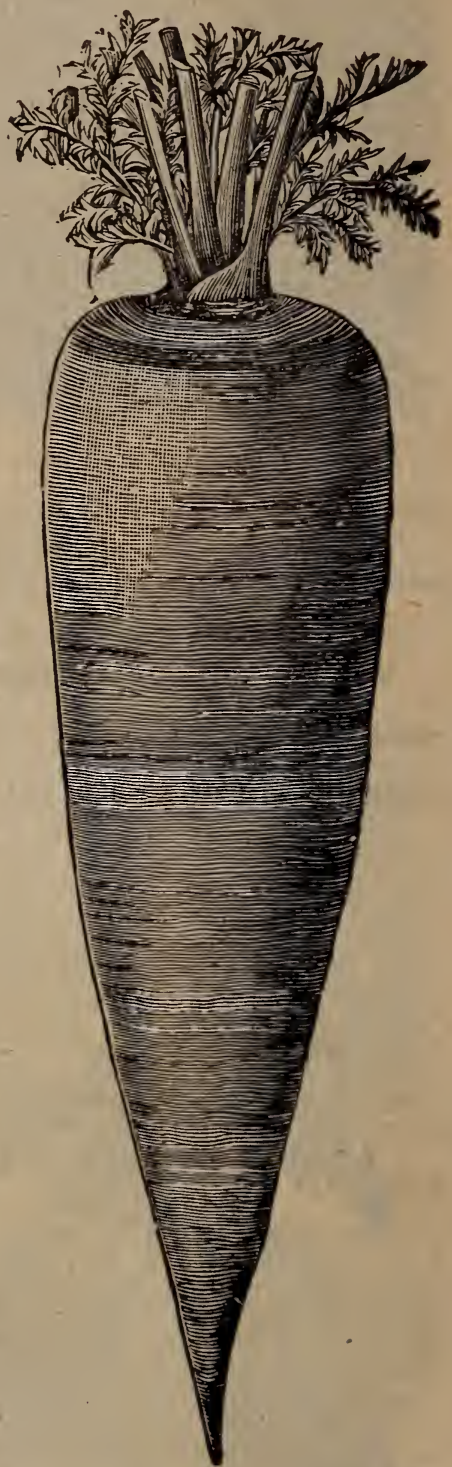

IMPROVED LONG ORANGE SCARLET.

Improved Long Orange. Our Improved Long Orange Carrots, as will be seen by the illustration annexed, are far superior to the ordlnary varieties of Long Orange Carrots, and will yield fully twice as much to the acre as the commonivarieties. In no other vegetable has there been such improvements recently made as In the Carrot, and we claim to have best strain of Long Orange Carrots there is to be found in this country. We ask our friends to:give it a trial, and be convinced of its great superiority. Pkt. $5 \mathrm{c} ; 0 z .10 \mathrm{c} ; 1 / 4 \mathrm{lb} .20 \mathrm{c}$; 1b. 50 c 5 Ibs. $\$ 2.25$. 


\section{CAULIFLOWER. $-\left\{\begin{array}{c}\text { Imported Direot from Our Grower in Denmark. } \\ \text { Choice Seleoted Varieties. }\end{array}\right.$}

COLTURE. - The most delicate and delicious of all the Cabhage family, and requiring the same culture and treatment, but being more delicate, the good culture and richness of the soil recommended for Cabbage. are absolutely necessary for Caulianwer. By sowing the early varieties in the Spring in a hotbed or cold rame, or even in an open border, they can be obtained in pretty good season. One ounce of seed will produce about 2,600 , lants.

Extra Selected Extra Early Dwarf Erfurt. One of the earliest varieties; small-leaved dwarf, for forcing; producing verv solid, pure white heads of the finest quality; about fifteen inches high- Don't confound this variety with the cheaper Early Dwarf Erfurt. Pkt. $20 \mathrm{c} ; 1 / 40 z .75 \mathrm{c} ; 1 / 2 \mathbf{0 z} . \$ 1.25 ; 0 z \$ 2.25 ; 1 / 4 \mathbf{l b}$. $\$ 7.50$.

Large Late Algiers. A splendid late variety; very popular with canners and market gardeners. Seldom fails to produce large white heads. $\mathrm{Pkt} .10 \mathrm{c} ; 0 z .75 \mathrm{c} ; 1 / 4 \mathrm{~b} . \$ 2.00$.

Extra Early Paris One of the ear'iest varieties in cultivaticn Very dwarf, large white compact heads of finest quality. Highiy recommended; sure heading variety Pkt. $5 \mathrm{c} ; 1 / 4 \mathrm{oz} .20 \mathrm{c} ; 1 / 2 \mathrm{oz} .35 \mathrm{c} ; 0 \mathrm{z} .65 \mathrm{c}$.

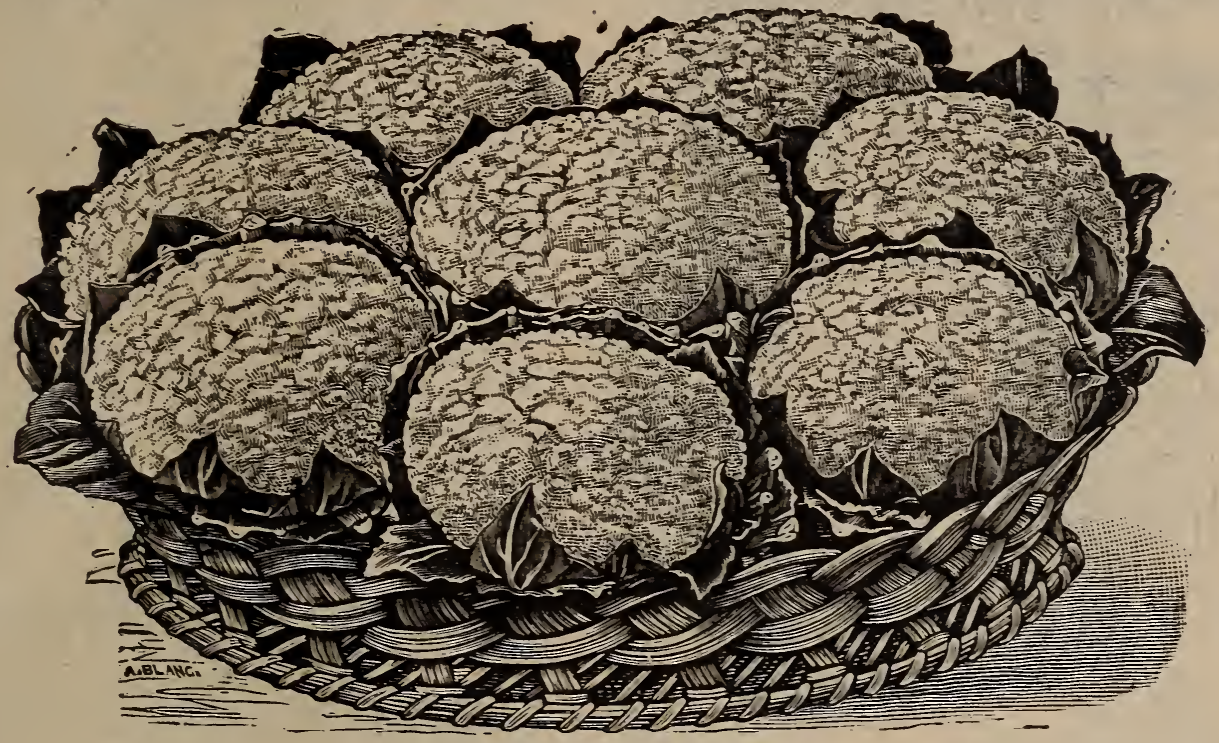

GILT EDGE EARLY SNOWBALL.

Gilt Edge Snowball. The strain we have of this variety is without doubt the very best to be had. Our stock was groou from the very finest specimens, noled for their earliness, dwarf habit, large size, uniform shape and compact growth. For forcing under glass during Winter and early spring. or for planting in the open ground, no stock of Snowball can surpass it. Pkt. $25 \mathrm{c} ; 1 / 4$ oz, 75c; $1 / 2$ oz. $\$ 1.25$; 1 oz. $\$ 25 ; \% 1 / 4$ lb. $\$ 8.00$.

Canliflower Plants-Ready May 1st. Suowball and Erfurt. By mail, doz. 20c; 100 . \$1.25. By ex. pr'ss, $100, \$ 1.00 ; 1,000, \$ 7.00$. Less price for other varitties.

\section{CELERY.}

THE FINEST $\triangle N D$ MOST SUPERIOR STRAIN OF CELERY SEED GROWN IN THE WORLD.

One ounce will produce about 3,000 plants.

CULTURE.-A very popnlar and now extensively grown vegetable. It can be grown - with success in any ordinary good soil but attains perfection in deep mellow, bottom land. Sow when the apple is in bloom, on finely raked surface and cover scarcely at all, quite early in the Spring in a moist place or con. venient to water, which apply freely in dry weather. When the plants are four iuch (more or less) in height, trasplant a portion into very shallow trenches in

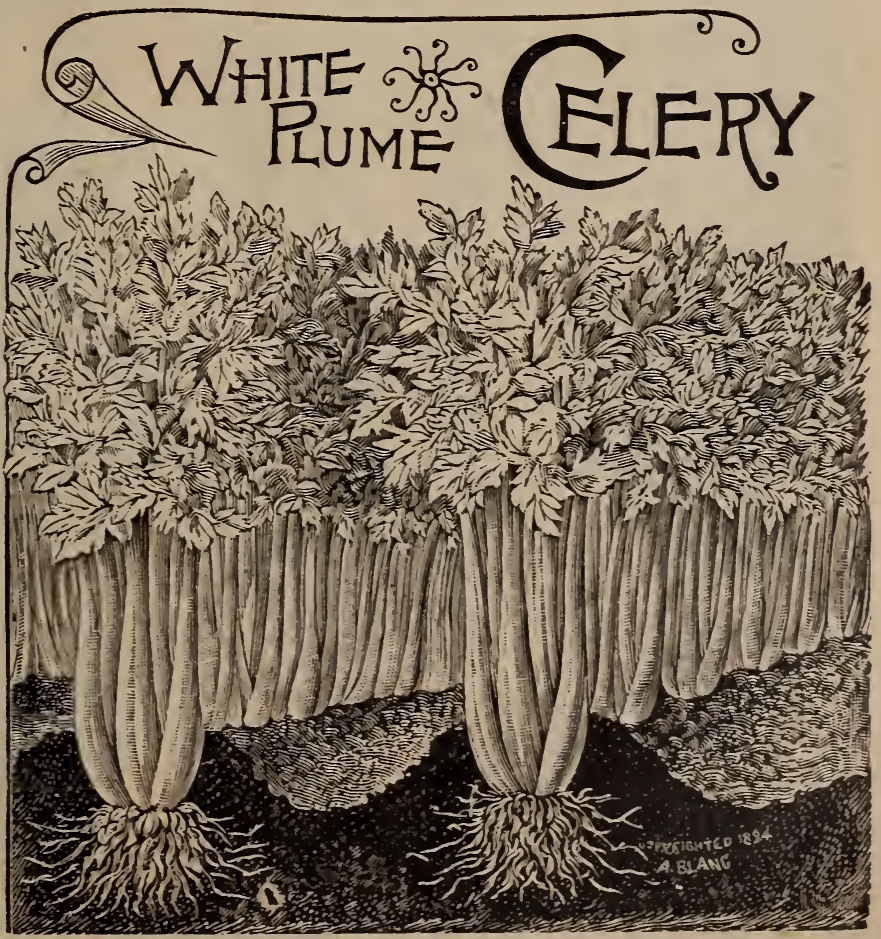




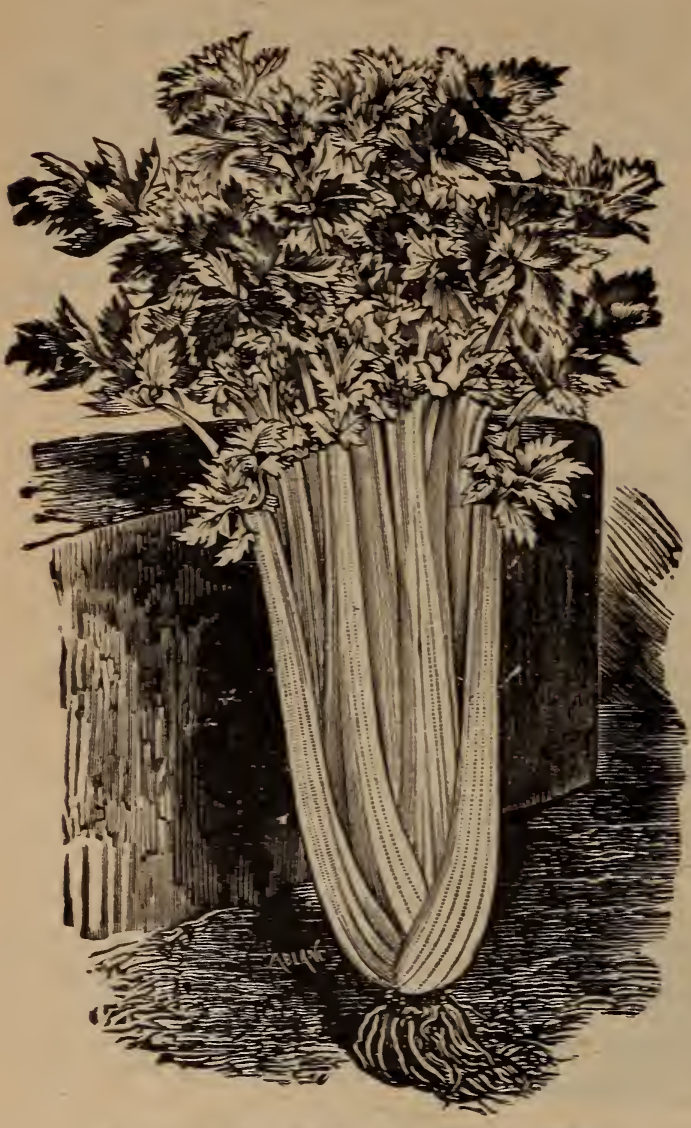

SEW GOLDEN SELF-BLANCHING CELERY. well-manured land, - hich planting repeat at intervals of two or three weeks for a succession. unti? the necessary quantity is set out.

White Plume Celery. The earliest and hand. somest, the easiest grown and most profitable for early market, $U$ hite Plume is sell.bleaching : the stalk and portions of the inner leaves and heart are naturally white; needs very little banking up to blanch; crisp, solid and of a nutty flavor, while its white. feather-like foliage places it at the head of all ot hers as a tatle ornament. Our seed can be relied upon as the "True White Plume." We have made a specialty of White Plume ever since its introduction. Pkt. $5 \mathrm{c}$; oz. $20 \mathrm{c}$ : $1 / \mathrm{llb}$ l F0c; $1 \mathrm{~b} . \$ 1.75$

Boston Market. A very superior market variety much esteemed for family and market use and a good keeper. Pkt. 5c; oz. 20c; 1/41b. 40c; 1b. $\$ 1.25$

New Golden Self-Blanching (Golden-Tellow. Large, Solid) This is the best Celery in cultivation. and it cannot be too highly recommended. The plant, with its close habit compact growth, and straight. vigorous stock, has a beautiful ap pearance. The ribs are perfectly solid. crisp. brittle and of delicate flavor, surpassed by no other variety, while it has the decided merit of being self-blanching to a very remarkable degree. The heart is large, solid, a nd of a beautiful, rich goldenyellow color. The leaves also are of a beantiful golden-yellow after the plant bas been bleached, which adds greatly to its handsome appearance. when prepared for the table. No variety can surpass, if indeed, equal the Golden Self-Blanching in striking appearance and delicious flavor. Exceedingly ropular with every planter. Excellent sort for early planting and good keeper. Pkt. $5 c$ : 0z. 2 cc; $1 / 41$ b. $75 c$; 1b. $\$ 300$.

Crawford's Half-Dwarf, A great favorite with mark gardeners. Early, solid, vigorous growth. and nutty flavor; very ornamental and exceeds many of the larger growing kinds in weight Pkt. 5c. oz. $15 \mathrm{c} ; 1 / 41 \mathrm{~b} .40 \mathrm{c}$; 1b. $\$ 125$.

Gisnt White Solid. The best of the large growing sorts and a favorite variety, solid, crisp and tender. Pkt. $5 \mathrm{c} ; 0 \mathrm{z} .20 \mathrm{c} ; 1 / 4 \mathrm{lb} .10 \mathrm{c} ; \mathrm{lb} . \$ 1.50$.

Red or Pink. A variety fancied by reason of its distivctive color aud hardiness. Quality good desirable in the private garden as one of the most reliable sorts. Pkt. $5 \mathrm{c} ; 1 / 20 z .10 \mathrm{c} ; 0 \mathrm{z} .2 \mathrm{c} ; 1 / 4 \mathrm{lb}$ sic; 1 b. $\$ .00$.

New Giant Pascal. The latest and best variety of Celerr. It is a selection from the Golden Self. Blanching and adds to the geveral good qualities of its parent, superior keeping qualities. The stalks are very large, thick, solid, crisp, and of a rich. nutty flavor free from 8 ny laste of bittervess. II blanches very easily and quickly, and retains its freshness a long time after being marketed. The heart is golden-

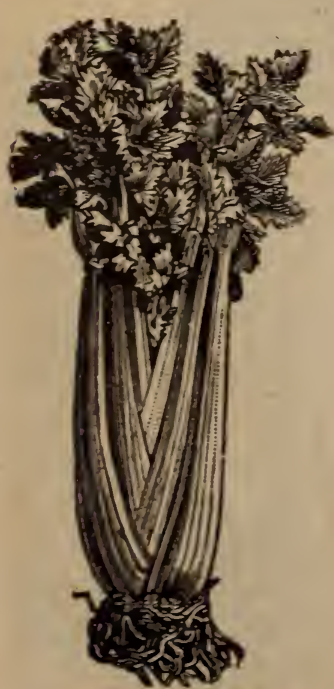

DAET GOLDEN BBART yellow, very full and at. tractive in appearance. Pkt. $5 \mathrm{c}$; oz. $15 \mathrm{c}$ : $1 / 4 \mathrm{db}$. $40 \mathrm{c} ; 1 \mathrm{~b} . \$ 1.50$.

Dwarf Golden Heart A distinct variety of sturdy dwarf habit. It is solid and an excellent keeper, and of fine nutty flavor. When blanched, the heart, which is large and full, is of a light yellow, making it an exceed. ingly showy and desira. ble varitty for either market or private use. Pkt. $5 \mathrm{c}$; oz. $15 \mathrm{c}$; 采 $1 \mathrm{~b}$. $10 \mathrm{c} ; 1 \mathrm{~b}$. \$1.25.

Mixed Celery Seed. For flavoring. Oz. $5 \mathrm{c} ; 1 / 4 \mathrm{lh}$. uc : 1b. $25 c$.

Celery Plants. Ready May 1st By mail, doz. Euc; $160, \$ 100$. By express 100 60c: 1.000 , $\$ 4.00$. After June $20 \mathrm{cb}$. \$3.00 per 1,000 . 


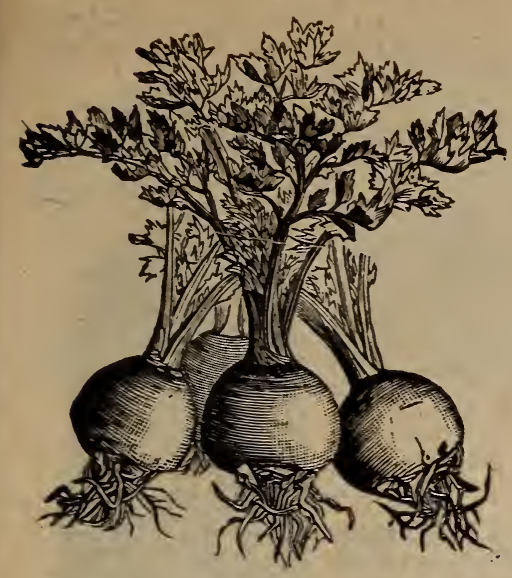

CELERAIC

\section{CELERAIC, OR TURNIP-ROUTED CELERY.}

CUL,TURE. - SOw early in the Spring in light, rich soil ; transplavt in May into beds. Grown exclusively for its scots, which are turnip shaped, very smooth, tender and marrow-like. The roots are cooked and sliced; used with vinegar they make an excellent salad. They are also used for seasoning meats and to flavor soups.

Prague Giant. Of fine flavor and large size. Pkt. $5 \mathrm{c} ; 1 / 2 \mathrm{oz} .10 \mathrm{c}$ oz. $20 \mathrm{c} ; \mathrm{x} / \mathrm{lb}$. $50 \mathrm{c}$; $1 \mathrm{~b} . \$ 1.50$.

\section{CherviL.}

Curled. Aromatic berb. The young leaves are used in soups or salads. Sow thinly in May, in drills half an inch deep, one foot apart. Pkt. $5 \mathrm{c} ; 0 z .15 \mathrm{c} ; 1 / 41 \mathrm{1b} .30 \mathrm{c} ; 1 \mathrm{~b} . \$ 1.00$.

\section{CHICORY.}

Large-Rooted Magdeburg. Roots of this form the Chicory of commerce. Used to mix with or as a substitute for coffee. Cultivation the same as for Carrot. Pkt. $5 \mathrm{c} ; 0 \mathrm{z} .10 \mathrm{c} ; \mathrm{y} / \mathrm{lb} .30 \mathrm{c}$ Ib. $\$ 1.00$.

\section{CHIVES.}

Chives are very hardy and perennial members of the onion family. They are grown exclurively for their tops, which are used whenever the flav ir of onion is wanted. Planted in clumps in any garden soil, they grow readily and increase so as to render a division necessary. The tops appear very early in the Spring, and can be cut throughout the season. They should have a place in every garden. Roots, per bunch, $25 \mathrm{c}$, postpaid.

COLlards.

True Genrgian, or Creole. Excellent for greens; quite extensively grown in the South. Sow for succession from June to August, and treat as Cabbage. Pkt. $5 \mathrm{c} ; 0 \mathrm{z} .10 \mathrm{c} ; 1 / 4 \mathrm{lb} .30 \mathrm{c} ; 1 \mathrm{~b} . \$ 1.00$.

\section{SWEET OR SUGAR CORN.}

QROWN UNDER CONTRACT.

Special Prices will be made for Larger Quantities than here qnoted.

The Sweet Corn we off er is grown under contract here in Ohio and Corn grown in this section is acknowledged by all seedsmen and gardeners to be second to none. We could buy splendid looking Sweet Corn, grown in western States. at one-half the price we paid for ours, but we prefer to work for the benefit and interest of our customers as well as our own, even at less profit. HALF PECK AND HALF BUSHEL AT PECK AND BUSHEL RATES.

CUITURE.-The Sweet or Sugar Corn varieties being liable to rot in cold or wet ground should not be planted until May. or when the ground has become warm, and for a succession plant every two weeks until the last week of July, in hills $2 \times 3$ feet for the early kinds, and $3 \times 4$ for the large late kinds Some plani in drills $3 \frac{1}{2}$ feet apast and eight inches in the row. Give frequent and thoroug $\mathrm{b}$ cultivation. One quart plants 200 to 300 hills. Eight or ten quarts for an acre.
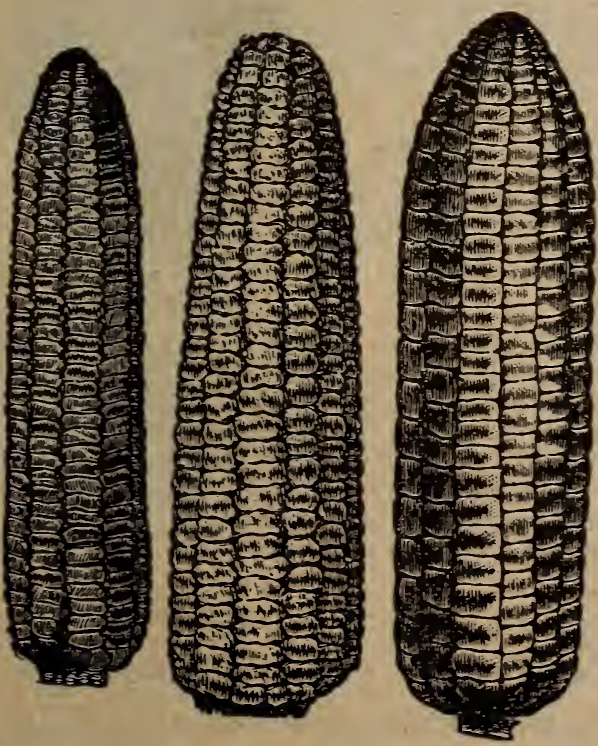

SHARERS' MUNTESOTA.

RA EARLY EGYPTIAN, OR
CORN. WASEINGTON MARRET.

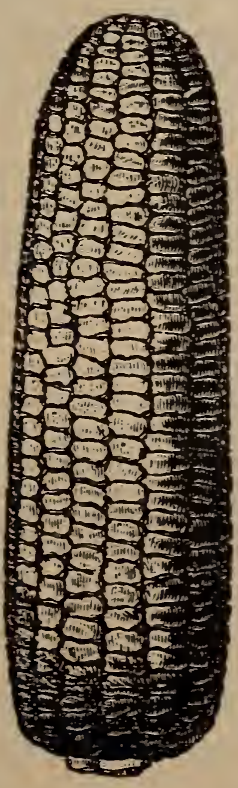

MAMMOT E SUGAR.
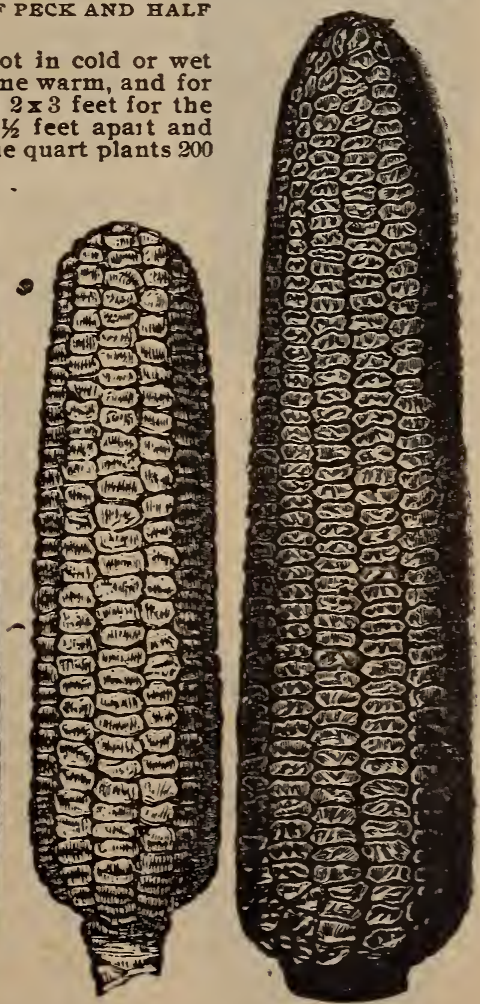

RARLY BVERGRERN 
Extra Early Adams. The Earliest White Corn; ready for table sixty days after germination. Height of stalk three to four feet; not a Sugar Corn, but a decided acquisition so very early in the season. In large demand among market gardeners. Pkt. tc; pint $10 c$; quart $15 \mathrm{c}$; peck; $5 \mathrm{c}$.

Now Cory. Extra early. The earliest variety of Sweet Corn known. Bas a large ear, considering the aize of the stalk and its extreme earliness; small cob, well filled with broad, deep grains; good quality. Pkt.
bc; pint $10 \mathrm{c}$; quart $15 \mathrm{c}$; peck 75c.

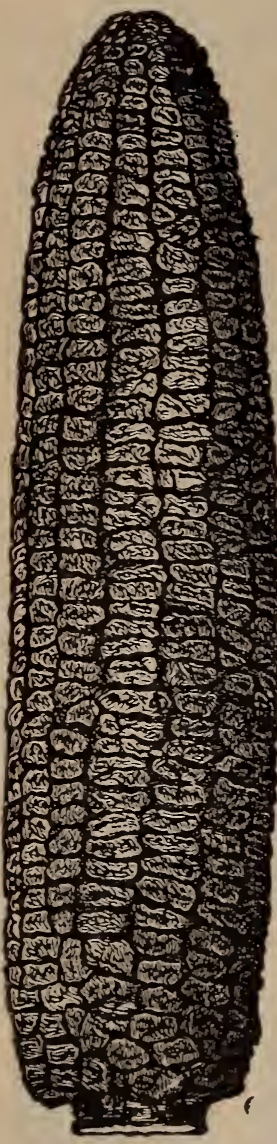

PHILIPPS' NEW WONDER CORN.

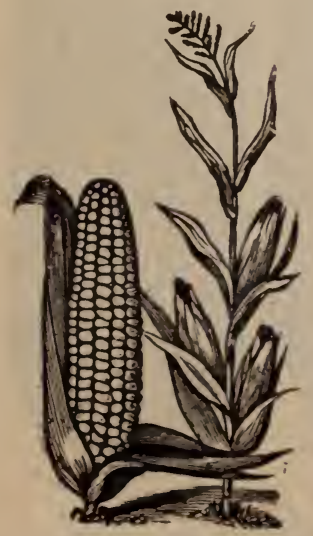

BICKOX CORN.

Extra Early White Cory. In all respects identical with New Cory, except color. kernels ana cob being white : earliness the same. This removes an objection some have to the Cory on account of its color. Pkt. $5 c$; pint $10 \mathrm{c}$; quart $15 \mathrm{c}$; perk $75 \mathrm{c}$.

Mammoth White Cory. The largest and best extra early variety of Sweet Corn. The stalks are not mucb larger than the white cob Cory and each stalk furnishes two or more large fine shap-d ears before other varieties are ready for market. Pkt. 5c; pint $10 \mathrm{c}$; quart $20 \mathrm{c}$; peck $\$ 1.00$.

Shaker's Early. Ready about the same time as the Farly Minnesota, but the ears are much larger; from two to three large eais to the stalk; keruels large of pearly whiteness and delicious flavor. Pkt. 5c; pint 10c; quart $15 \mathrm{c}$; peck $7 \mathrm{jc}$.

Early Minnesota. One of the earliest sorts of Sweet Corn. ears of suitable size for market purpos.s, esteemed for is excellent qualities. Pkt. $5 \mathrm{c}$; pint $10 \mathrm{c}$; quart $15:$; peck $75 \mathrm{c}$.;

Crosby's Early Sugar. Early, great favorite in the market, produc'ive and of excellent quality. Pkt. $5 \mathrm{c}$; pint $10 c$; quast $15 c$; Deck $75 c$.

Moore's Early Concord. A good second early. Many gardeners plant it as late as July 1st, as the ear will sell as well as Stowell's Evergreen. Pkt. 5c; pint $10 \mathrm{c}$; quart $15 c$ : peck $25 c$.:

Ohio Red Cob Evergraen Sugar. This variety we consider one of the best for a general crop, coming imme. diately after the serond earliest. It is very productive. has large, well filled ears. with deep kernels and smail cob, is very sweet. Pkt. 5c; pint $10 \mathrm{c}$; quart $15 \mathrm{c}$; peck 80c،

The Hirkox Corn. A large variety, very white. tender and sweet. It grows eight. ten and twelve rowed. great farorite with those who can corn for mirket. It ripens about a week earlier than Stowel!'s. The ears are longer and not quite as thick as Stowell's. Highly recommended. Try it. Pkt. $5 c$; plnt $10 c$; quart $15 c$; peck $75 c$.

Stowell's Evergreen. Grown more extensively than any other variety, being a great favorite with canners and market gardeners for late use. The ears are of large size, kernels very deep, tender and sugary; very productive and remains a long time in fit condilion for table use. Pkt. $5 c$; pint $10 c$; quart $15 c$; peck $75 c$.

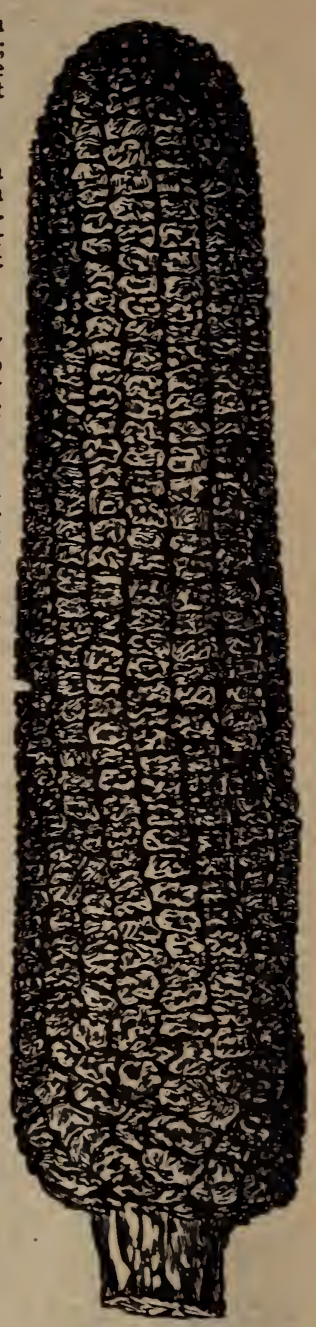

ORIO RED COB EVERGREEN CORN.

Philipps' New Wonder Early Sweet Corn. We offer this new Sweet Corn as the New Wonder of all the early varieties of Sugar Corn ever grown. Its great merit is its earliness, large yield, with ears as large as Stowell's Evergreen, with two and three ears to stalk. Kernel pure white, very delicious, sweet and tender, and the most wonderful extra early large eared Sweet Corn ever introduced. We confidently recommend this New Wonder to the Market Gardeners as a great money maker, and should be in every private garden. Our supply is limited, and would advise all in want of this choice Corn to order early. Pkt. $5 c$; pint $10 \mathrm{c}$; quart $20 \mathrm{c}$; peck $\$ 1.00$.

We are recleaners of all kinds of Field Seөds and Grain and do not mix Medium with Mammoth Red Clover, but keep them separate, and ask our friends to write for our Field Seod Price List-mailed free. 


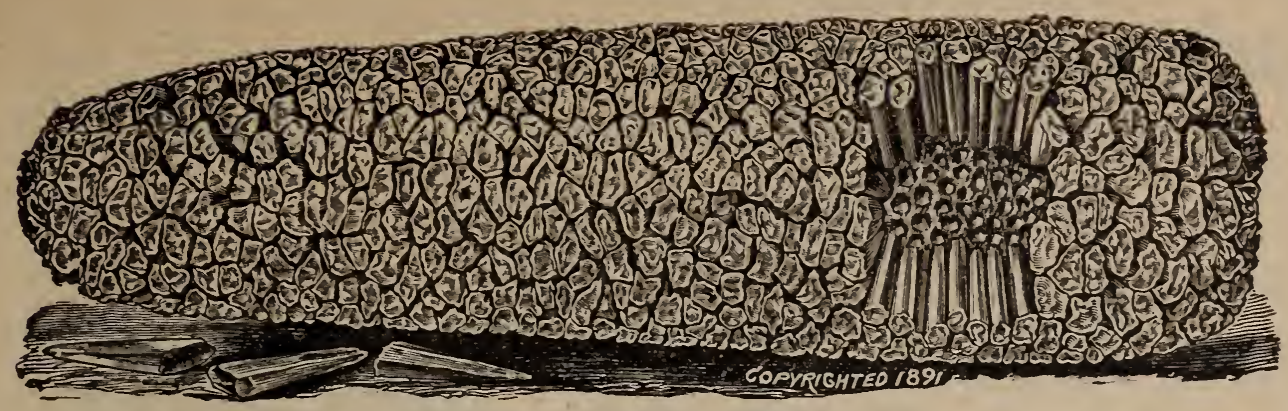

COUNTRY GENTLEMAN.

Country Gentleman \&weet Corn. This is one of the finest of all sweet Corns for private table. The shape of the kernels on the cob indicate high quality. The moment your teeth sink into this luscious, milky, tender corn, you will become a complete convert to it, for it will delight the most fastidious epicure. Ears: are plump, milky, pearly white, kernels fairly melting in your mouth, retaining its delicate flaror and tenderness even when a little old. Medium early, very productive, each stalk yielding three and often four ears. The Country Gentleman is also the most profitable sort for Market Gardeners and dealers. The ears are enclosed in a heavy busk, which tends to keep the ear in the milk for several days longer than any other corns. The ears average eight to nine inches in length, a very attractive size for table. The cob is usually small, and the pearly white kernels of great depth, of delicious quality and flavor. Don't miss trying it. Price, pkt. Ec; pint $10 \mathrm{c}$ : quart $20 \mathrm{c}$; peck $90 \mathrm{c}$.

Russell's Prolific. Only a few days behind the earliest. As large as the Evergreen, kernels very large pearly white and sweet, ears are ten to twelve rowed, large and plump; stalks strong, bearing two or three ears each. Pkt. $5 c$; pint $10 c$; quart $15 \mathrm{c}$; peck $75 \mathrm{c}$.

Black Mexican. A black-grained variety, one of the sweetest of all kinds. Pkt. $5 c$; pint $10 c$; quart $15 c$; peck 75c.

Egyptian or Washington Market. Ears of large size. Very sweet and of rich flavor. Very productive; used extensively for canning. Pkt. $5 \mathrm{c}$; pint $10 \mathrm{c}$; quart $15 \mathrm{c}$; peck $75 \mathrm{c}$.

SWEET CORN IS ONE OF THE BEST paying crops to grow. If it cannot all be disposed of in the greeo state, for table use, the corn in its dry state, also the fodder, is very valuable.

\section{POP CORN.}

Early White Rice Pop Corn. One of the finest and most prolific Pop Corns grown. Pkt. $5 c$; pint $15 c$; quart 25c.

At Prioes Quoted, Postage is Paid on Beans and Corn in Paokets Only.

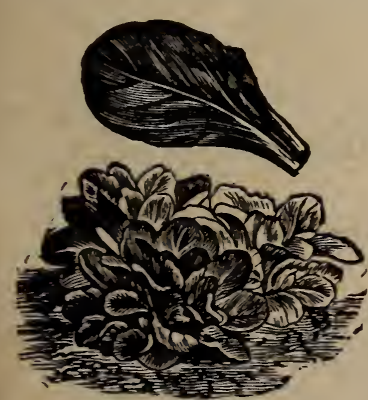

CORN SALAD.

\section{CORN SALAD, OR FETTICUS.}

CULTURE.-SOW during August and September, in drills or broadcast. Keep down weeds with hoe. Just before the first of the Winter cover thinly with clean straw or leaves. A delicious hardy salad.

Large Seeded. Pkt. $5 \mathrm{c}$; oz. $10 \mathrm{c} ; 4$ oz. $25 \mathrm{c}$; 1.b. $75 \mathrm{c}$.

\section{CRESS.}

CULTURE.-Sow thick in shallow drills every two or three weeks. Cut often it will continue to grow. Useful as salad. for breakfast table and garnishing. True Water Cress should be grown in damp soil : if a stream of water could be utilized it would be much finer; will also thrive in damp hotbeds.

Curled or Pepper Grass. Pkt. $5 \mathrm{c}$; oz. $10 \mathrm{c} ; 1 \mathrm{~b} .50 \mathrm{c}$.

Broad Leaved. Pkt. $5 c$; 0z. 15c; lb. 75c.

True Water Cress. Pkt. $10 \mathrm{c} ; 0 \mathrm{z} .30 \mathrm{c} ; 1 \mathrm{~b} . \$ 3.00$

It is of the Greatest Importanoe to Market Gardeners, also private families, to get the Farliest, Sweetest, most Delicious snd most proliflc Sweet Corn grown in this country. We can supply you with such, as our Sweet Corn Seed is Connecticut and Ohio grown exclueively. We therefore advise you to consider your own interest and send your order to us, which will have prompt attentlon Market Gardeners should read carefully discounts on page 2. 
VEGETABLE SEED.

\section{5 cent Collection, by mail, postpaid.}

1 Package Beet, Early Blood Turnip.

1 " Cabbage, Early Summer.

1 " " Large Late Flat Dutch.

1 “ Cucumber, Toledo Market Evergreen.

1 “ Lettuce, Early Curled Simpson.

1 "Onion, Prize Taker.

1 “ Radish, Extra Early Scarlet.

1 "Tomato Dwarf Champion.

FLOWER SEED.

25 cent Collection, by mail, postpaid.

1 Package Asters, Mixed.

1 " Balsam, Double Mixed.

1 “ Mignonette, Sweet.

1 " Nasturtium, Mixed,

1 " Pansy, Choice Mixed.

1 “ Petunia, Choice Mixed.

1 " Sweet Peas, Choice Mixed.

1 “ Ten Weeks' Stock.

1 " Zinnia, Double Mixed.

VEGETABLE SEED.

50 cent Collection, by mail, postpaid.

1 Package Peas, Philipps' Early Summit.

1 " Beans, Golden Wax.

1 " Sweet Corn, Early Cory.

1 “ Beet, Early Blood Turnip.

1 " Cabbage, Large Late Flat Dutch.

1 " " Early Summer.

1 “ Cucumber, Improved White Spine.

1 “ Lettuce, New Salamander.

1 " Water Melon. Improved Dixie.

1 “ Musk Melon, Hackensack.

1 “ Onion, Silver Skin.

1 “ Parsnip, Hollow Crown.

1 " Radish, Extra Early Scarlet.

1 "Tomato, Dwarf Champion.

There are no Better Collections of Seeds to be had for the Money Anywhere in the World-Full-Sized Packets. 


\section{CHOICE CUCUMBER SEED.}

NORTHERN GROWN FROM CARKFULLY SELECTED SEED STOCKS.

Growers of Large Quantities of Cucumbers should Write to as for Special Prices

One Ounce for Fifty Hills. One to Two Pounds for an Acre,

SLug Shot is Death to the Bugs.

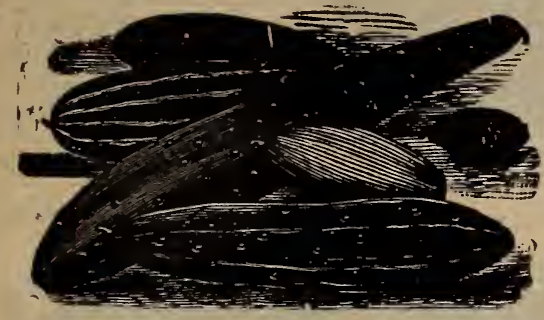

CULTURE.-For very early sow seeds in hotbeds upon pieces. of sod, or in small pots, and they can be readily transplanted. with a gain of about six weeks before they can be sown in the open ground. Plant out in rich soil, when danger of frost is over. For general crop sow in open ground as soon 25 the weather is settled and warm, and again every two weeks for a succession. For pickles, sow from the middle of June to the first week in August.

Farly Russian. Earllest in cultivation, hardy, prolific, only about three inches long; fine for pickles; unsurpassed for table use ; remarkably solid, with very few seeds and of best quality. Pkt. $5 \mathrm{c}$; oz. $10 \mathrm{c} ; 3 / 41 \mathrm{~b} .20 \mathrm{c} ; 1 \mathrm{~b} .50 \mathrm{c}$.

Fxtra Early Frame, or Early Short Green. Although often sold under each name as different varieties, both are one and the same cusumber. Productive, of vigorous growth, early fruits of medium size, straight and well-formed; popular for both table use and pickling. Pkt. $5 \mathrm{c} ; 0 \mathrm{z} .10 \mathrm{c} ; 1 / 4 \mathrm{lb} .20 \mathrm{c} ; 1 \mathrm{~b} .5 \mathrm{c}$.

Garly Green Clugter. Fruit small and in clusters; valuable for pickles. Pkt. $5 \mathrm{c} ; 0 \mathrm{z} .10 \mathrm{c} ; \mathrm{x} / \mathrm{lb}, 20 \mathrm{c} ; 1 \mathrm{~b}$. $50 \mathrm{c}$.

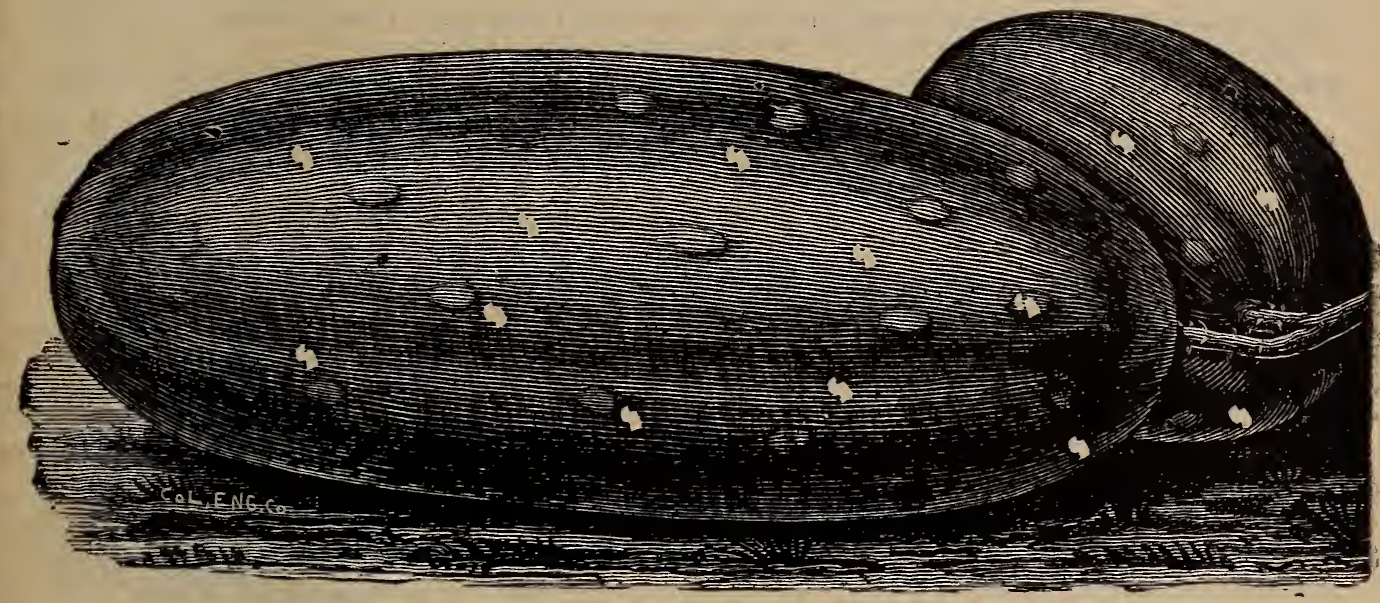

TOLEDO YARKET EVERGREEN WHITE SPINE.

Toledo Market Evergreen White Spine. A new and improved strain of the well-known White Spine, and fast becoming the favorite with market gardeners'both for forcing and outdoor culture. It differs from the ordinary White Spine in the fact of alway's REMAINING OF A DEEP GREEN cOLOR in all stages of growth.

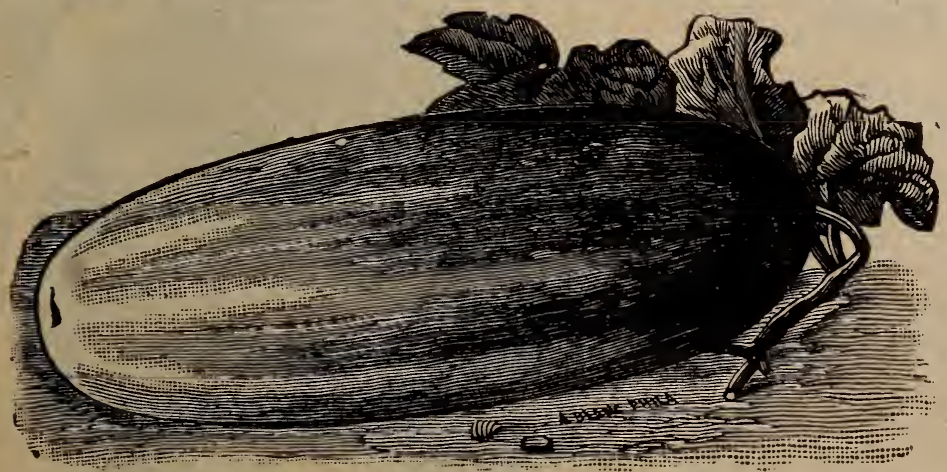
Altogether it is a most welcome and valuable acquisition for pickling, market or home use, and should be tried by all who bave a garden. Pkt. $5 c$; oz. 10c; $3 / 2$ 1b. 20c: 1b. 50c.

Improved Extra carly White Spine. For both market use and pickling this variety is now more largely grown than any other, and is very much superior to the old White Spine. Our stock is grown from the true Boston strain. Pkt. $5 c ; 0 z .10 c ; 1 / 4$ 1b. 20c:

IMPROVED EXTRA IARLY WHITE BPINE. lb. 50 c. 


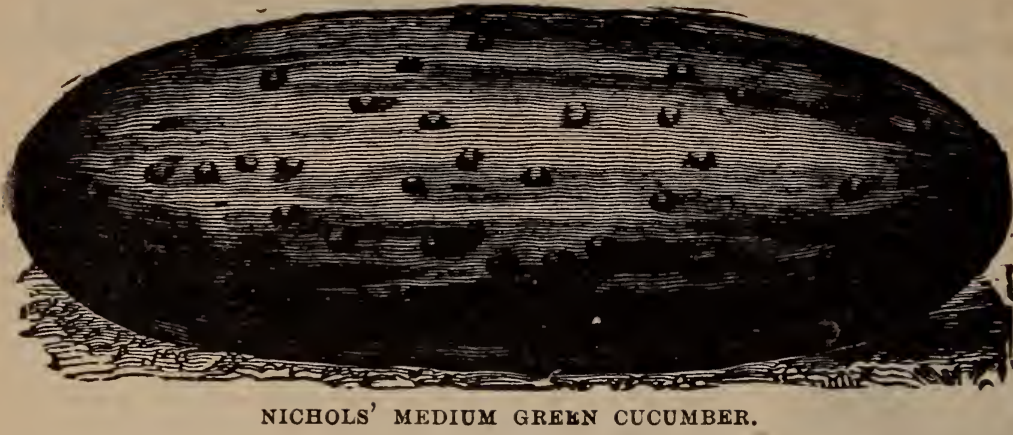

Nichols' Modium Green Cucumber. This new Cucumber is wortby of the first place among pickle sorts, second to none as a slicer, and very good for early forcing purposes; in color dark green; flesh crisp and tender; productive, medium in size, always straight and smooth, a real handsome good variety. Pkt. $5 \mathrm{c}$; oz. $10 \mathrm{c} ; 1 / 4 \mathrm{lb} .20 \mathrm{c} ; 1 \mathrm{lb} .50 \mathrm{c}$.

Dong Green Improved. Long. crisp and a popular and reliable variety for pickling and slicing for table ; good for general crop. Pkt. $5 \mathrm{c} ; 0 z .10 \mathrm{c} ; 1 / 4 \mathrm{lb} .20 \mathrm{c} ; 1 \mathrm{~b} .50 \mathrm{c}$.

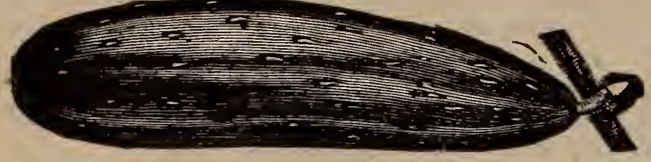

EXTRA GREEN PROLIFIC PICKLING

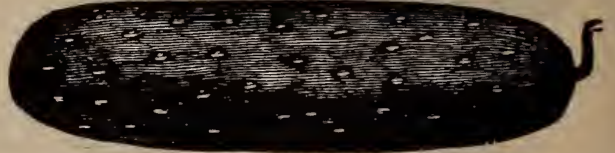

BOSTON OR JERSEY PICKLING.

Extra Green Prolific Pickling. One of the best for pickling; dark green, very productive and of uniform small size; very few seeds. Pkt. $5 \mathrm{c} ; 0 z .10 \mathrm{c} ; 1 / 4 \mathrm{lb} .20 \mathrm{c} ; 1 \mathrm{~b} .50 \mathrm{c}$.

Boston or Jersey Pickling. A favorite eastern sort of fine quality, medium length; reliable variety for pickling and slicing. pkt. $5 \mathrm{c} ; 0 \mathrm{z} .10 \mathrm{c} ; \mathrm{r} / \mathrm{lb} .20 \mathrm{c} ; 1 \mathrm{~b} 50 \mathrm{c}$.

Lxtra Long White Spine or Evergreen. This variety often grows to exceed 12 inches in length. Very smooth, straight and handsome; is quite early, very prolific, of a dark green color in all stages of growth, crisp, tender aud free from bitterness. Pkt. $5 \mathrm{c} ; 0 z .10 \mathrm{c} ; \mathrm{x} / \mathrm{lb} .20 \mathrm{c} ; 1 \mathrm{~b} .5 \mathrm{cc}$.

Philipps' Everbearing. Small size; very early and enormously productive, aud valuable as a green pickle. Pkt. $5 \mathrm{c} ; 0 \mathrm{z} .10 \mathrm{c} ; \mathrm{r} / \mathrm{lb}, 20 \mathrm{c} ; 1 \mathrm{~b} .60 \mathrm{c}$.

The Emerald A new Cucumber of good quality that holds its color long after boing pickled and is almost free of warts and spines, good for forcing and shipping. Pkt. $5 \mathrm{c} ; 0 \mathrm{z} .10 \mathrm{c} ; \mathrm{1} / \mathrm{1b}$. $30 \mathrm{c} ; \mathrm{lb}$. 75c.

Trilby's Hybrid. A cross between the White Spine and a large English variety. Good for market and table Pkt. $5 \mathrm{c} ; 0 \mathrm{x} .10 \mathrm{c} ;$ 1. $1 \mathrm{~b}$ 1b. $20 \mathrm{c} ; 1 \mathrm{~b} .50 \mathrm{c}$.

Japanese Climbing. A real climbing Cucumber for small gardens on poles and trellis. Fruit throughout the season. Pkt. $5 c$; 0z. $10 c$; $1 / 4$ lb. $30 c ; 1 b .75 c$.

Arlineton. For market use this Cucumber is unsurpassed and is now largely grown by all Market Gardeners. Pkt. $5 \mathrm{c}$; oz. $10 \mathrm{c}$; $1 / 4$ 1b. $20 \mathrm{c}$; 1b. $50 \mathrm{c}$.

\$mall Gherkin. Very small burr; used for pickles. Pkt. $5 c$; oz. $20 \mathrm{c} ; 1 / 4 \mathrm{lb} .40 \mathrm{c} ; 1 \mathrm{~b} . \$ 1.00$.

\section{DANDELION}

Improved Large-Leaved. A very early and healthy Spring salad. Sow early in the Spring in drills eighteen inches apart and thin out to six inches in the drills Pkt. $10 \mathrm{c} ; 0 \mathrm{oz} .50 \mathrm{c} ; 1 / 4$ lb. $\$ 1.25$; lb. $\$ 4.50$.

\section{EGG PLANT.}

One Ounce will Produce about One Thousand Plants.

COLTURE.-Sow early in the hotbed. When plants are three or four inches high transplant two feet apart in rich, warm, dry soil. Cultivate same as cabbage.

To coOK.-Cut the slices one fourth to one.half inch in thickness; pare off rind; put into dish with a layer o salt between the pieces, beginning witb a layer of salt at the bottom of dish. Let stand three or four hours, then wipe each slice dry with a cloth; fry in a batter of egg: and flour; season to taste, and you have an excellent dish. Now York Improved Large Purple. The best variet! in cultivation; contract grown, Being early, a surt cropper; and of fiue quality. Fruit very large oval, deep purple; flesh white and tender. Pkt. 10c; $1 / 20 z$. $20 \mathrm{c}$; oz. $30 \mathrm{c}$ : $1 / 4$ lb. $\$ 100$.

rgg Plants. Ready May 1st. New York Improved. By mail, doz. 25c. By express, 100, $\$ 1.00$.

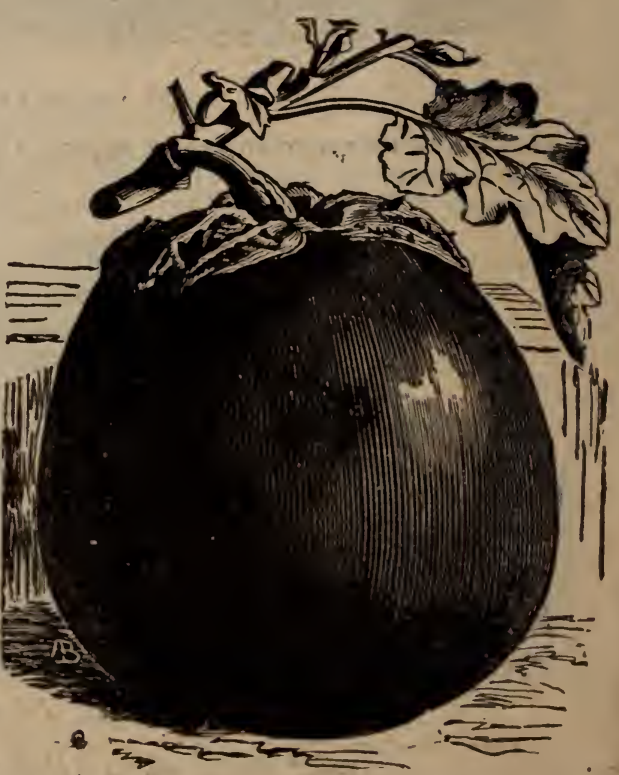

NEW YORK IMPROVED LARGE PURPLE EGG"PLANT. 


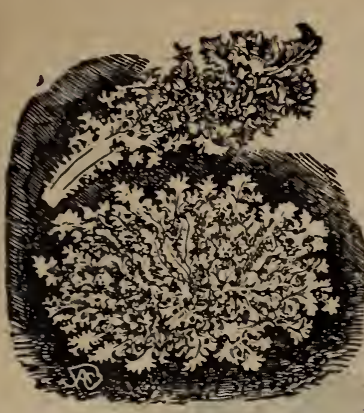

THITE CURLED ENDIVE.

\section{ENDIVE.}

CULTURE - For an early crop sow in April. For general crop sow in June or July; cover lightly. When up, thin out to eight inches apart. When the leaves are six or eight inches long, blanch by gathering in the hand and tying together near the top with yarn or bast. This must be done when quite dry, or they will rot. At the approach of Winter, take up carefully, with a ball of earth to each plant, and place close together in frame or cellar for use. They must be kept dry and have pleuty of air or they will rot.

Green Curled. Best for general crop, for early and late use ; crisp in quality. hardy. Pkt. 5c, oz. 15c: 4 oz. $40 \mathrm{c}$.

White Yoss Curled. Very beautifully curled ; for early season, fine flavored. Pkt. $5 \mathrm{c} ;$ oz. $15 \mathrm{c} ; 4$ oz. $60 \mathrm{c}$.

Broad-Lenved Batavia. Has broad, thick; slightly wrinkled leaves; pale green and good keeper. Pkt. $5 \mathrm{c} ; 0 z .15 \mathrm{c} ; 40 z .40 \mathrm{c}$.

\section{GARLIC.}

Garlic is the most pungent in taste and has the strongest odor of all the Onion family. It is esteemed for flavoring soups, stews. sausage, etc.

CULTURE.-Prepare ground and cultivate same as Onions.

Large Bulbs - 25c. per lb.

Small Sets or Seeds will make large bulbs. Per pound, $50 \mathrm{c}$.

\section{GOURD.}

CULTURE.-The Gourd is a tender annual, and should not be planted until the danger of frost is over and not less than six feet apart each way, in good rich loak.

Sagar Trough This variety grows to a very large size, and is valuable when dry for a variety of household purposes, baskets, etc. Pkt. 5c; oz-25c.

Dipper. Very useful for many purposes; holding about a quart, with a long handle. Pkt. 5c; oz. 25c.

Dish Cloth. Grow two feet in length. The lining and inner portion is sponge-like. tough and elastic, and used for dish-cloths. Pkt. $5 \mathrm{c} ; 0 \mathrm{z} .25 \mathrm{c}$.

Nest Egg. Japanese Nest Egg. They resemble a hen's egg in color, shape and size. Pkt. 5c. ; oz. 25c. Fine Mixed. A collection of the most ornamental, including all the above. Pkt. 10c; 3 pkts. $25 \mathrm{c} ; 0 z$. $25 \mathrm{c}$.

\section{KALE, OR BORECOLE.}

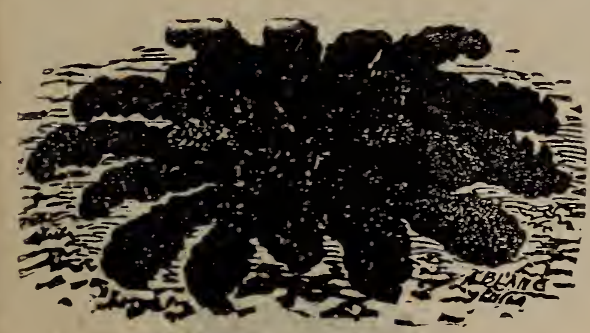

DWARF GERMAN CULED KALE.

CULTURE.-Sow from the middle of April to the beginning of May in prepared beds; transplant in June and treat in same manner as for the Cabbage. Of all the $\mathrm{Cab}$ bage tribe this is the most tender and delicate, and would be much more extensively grown than it is if its excellent qualities were generally known.' The varieties are extremely hardy and are best when touched by frost.

Carled Tall Green Scotch. Hardy; best after frost. Pkt. $5 \mathrm{c} ;$ oz. $10 \mathrm{c} ; 4$ oz. 30.

German Dwarf Grren Curled. Very fine; light green. Pkt. $5 \mathrm{c} ;$ oz I0c; 4 oz. $40 \mathrm{c}$.

German Dwarf Brown Carled. Very hardy. Pkt. $5 c$ : oz. $10 \mathrm{c} ; 4$ oz. $40 \mathrm{c}$.

\section{KOHL RABI.-Above the Ground or Turnip Rooted Cabbage.}

CULTURE. - When young and tender they are fine for table use; when matured they will keep well, and are excellent for Winter feeding to stock. For early use sow in hotbed;

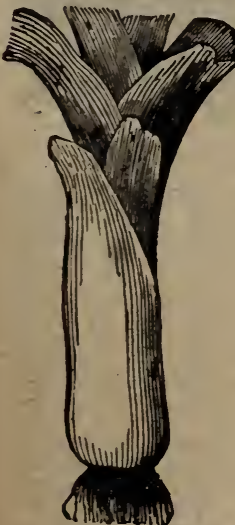

LARGE FLAG. transplant and cultivate like early Cabbage. For Winter use sow the middle of June or first of July, in rows ten inches apart. One ounce of seed for 1,500 plants.

Early White Vienna. Flesh white and tender, excellent forcing variety. Pkt. 5c; oz. 20c; 4 oz. 60c.

Early Purple Vienna. An excellent sort, later than the White, Pkt. $5 \mathrm{c} ;$ oz. $20 \mathrm{c} ; 4$ oz. $60 \mathrm{c}$.

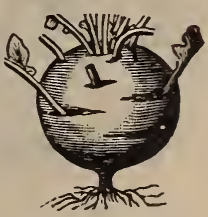

KОHL RABI.

\section{LEEK.}

One ounce will produce $1,00 n$ plants.

CULTURE.-Sow early in Spring. in drills six inches apart and one inct deep. Thin out to one inch. When about seven inches high. transplant them in rows twelve inches apart, and as deep as posible, but do not cover the young center leaves. Water thoroughly, if dry when planted ont. Draw earth up to them as they grow. Very rich soil is required. Take up and store in earth in a cool cellar before Winter weather.

Large Improved condon Flag. An old standard. Broad leaves of strong and vigorous growth; hardy. Pkt. $5 \mathrm{c}$; oz. $10 \mathrm{c}$ : 1 oz. $30 \mathrm{c}$.

Large Musselbnrgh, or Sontch Champion. Of enormous size. Leaves broad and tall, spread like a fan; hardy, and of excellent quality. We highly recommend this. Pkt. $5 \mathrm{c} ;$ oz. $15 \mathrm{c} ; 4$ oz. $45 \mathrm{c}$. 


\section{LETTUCE.}

One Ounce of Seed for 2,500 Plants.

Lettuce, the most used of all salads is of very easy culture; every gardener and garden spot should have a plentiful supply. With but little trouble and the proper selection of varieties, it can be had the whole year
round, while no other salad is so appetizing or more wholesome.

CULTURE-To have find Lettuce in early Spring. sow in seed-bed from commencement to middle of Autumn. Protect the plants by a cold frame or with litter, as they stand on the ground. Early in the Spring transplant them into rich ground. Or in early Spring sow in hotbeds and transplant. For a later supply sow in drills from time to tlme, during spring and Summer; when up a few inches thin out, leaving plants at proper distances; this is better than transplanting late in the season.
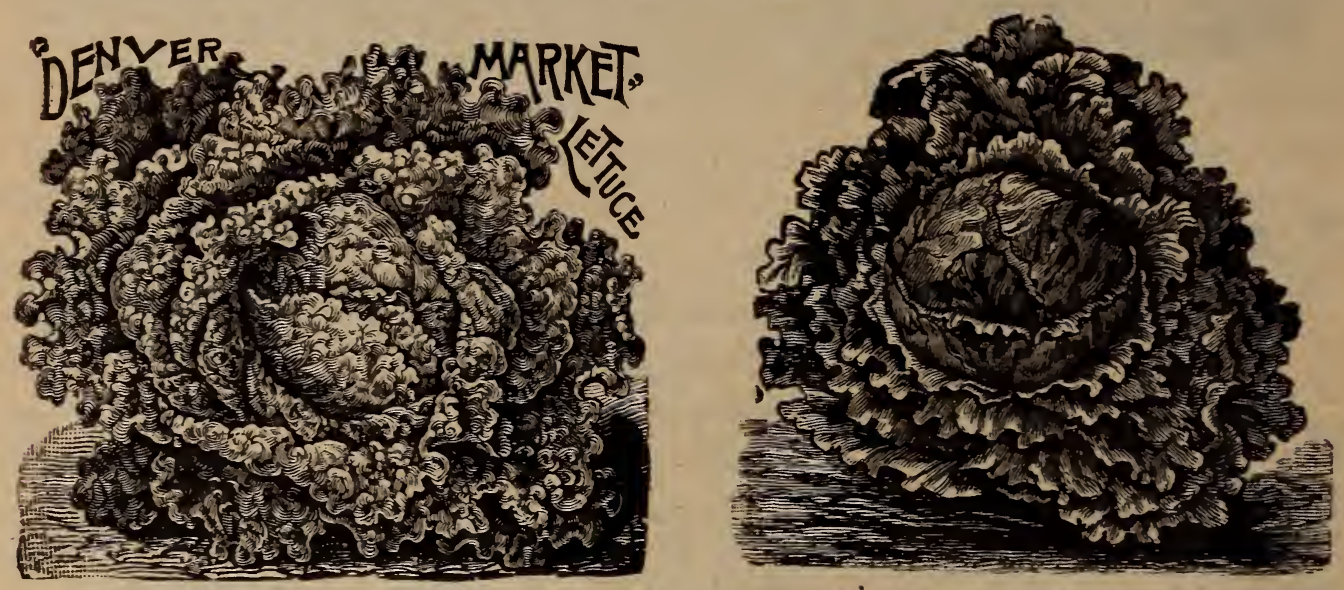

PHILIPPS' EARLY WHITE CABBAGE LETTUCE.

Denver Market. This novelty in Lettuce forms beautiful large, solid heads, of a delicate light green color. The leaves are blistered like a Savoy Cabbage, most attractive in appearance. It is very tender; of excellent flavor, grows quickly: is good to grow early in the open ground, yet is slow to run to seed. Pkt. $5 \mathrm{c}$; oz. $10 \mathrm{c} ; 4$ oz. $30 \mathrm{c} ; 1 \mathrm{~b} . \$ 1.00$.

Philipps' Early White Cabbage, or Butter Salad. This is our leading standard sort; heads large, solid, close and well-formed, very tender, crisp and of excellent flavor, and always free from bitterness. Desira. ble for forcing and for out of-doors. Plt. $5 \mathrm{c} ; 0 z .10 \mathrm{c} ; 4 \mathrm{oz} .30 \mathrm{c} ; \mathrm{ib} . \$ 1.00$.

Kcoberg. For four seasons we offered this beautiful Lettuce to our customers, and all so far as heard from, are highly pleased, and regard it worthy of general cultivation. The large curly leaves are of a bright light green, with a very slight redoish tinge at the edges. The unusual solidity of the heads is insured by the large white main ribs of the leaves, each of which curving strongly into the center acts like a truss, making it impossible for the leaves to open outward and expose the center, which is constantly thoroughly blanched. The quality is simply perfect. Pkt. $5 c ; 0 z .10 c ; 40 z .30 c ; 10 . \$ 1.00$.

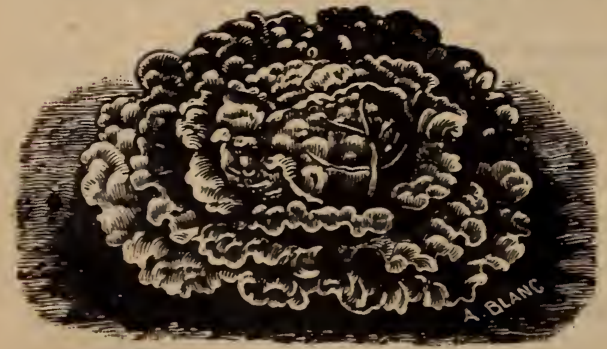

NEW SILVER BALL LETTUCE.

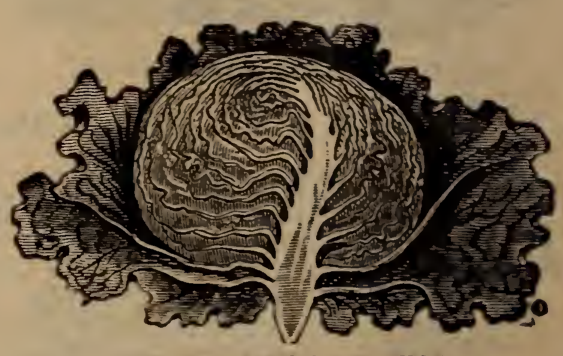

KARLY HANSON LETTUCE.

New silver Ball. This lettuce produces a beautiful head, very firm, solid and compact. with handsomely curled leaves. The head is of an attractive silvery white color, very rich, buttery, and of most delicious flavor. Early, and stands a long while before running to seed. An excellent variety, both for early Spring and Summer use. Pkt. $5 c$; oz. 10c; 4 oz. $30 c$; 1b. $\$ 1.00$.

carly Hanson. Improved hard-heading stock. Forming fine, large, solid heads, which are both crisp and tender They frequently attain two to three pounds each. We regard it as a very valuable variety. Pkt $5 c$; 0z. $10 \mathrm{c} ; 4$ oz. $30 \mathrm{c} ; 1 \mathrm{~b} . \$ 1.00$.

Tennis Ball. (White Seeded). A favorite forcing variety, forming a hard head. Can be planted quite closely under glass. Largely used in hotbeds and greenhouses; very hardy. Pkt. 5c; oz. 10c; 4 oz. $30 \mathrm{c} ; 1 \mathrm{~b} . \$ 1.00$.

Grand Rapid* Forelng. Beiag often disappointed in getting the genuine stock of this grand Iettuce, we have for several seasons been growing this seed here at home, and we recommend the same as pure and reliable. There is nothing superior. if it has any equal, for growing under glass: it requires less care, will grow more weight in the same space, is not liable to rot, and will keep longer without wilting than any other variety; is of fne appearance, crisp and tender. It is also valuable for outdoor growing. Pkt. 5c: oz. $10 \mathrm{c} ; 4 \mathrm{oz}$. $35 \mathrm{c}$; 1b. $\$ 1.25$. 


\section{The Henry Philipps Seed and Imp.}

Big Beston. This variety is identical in color. shape and general a ppearance with the famous Boton Market Lettuce, but is donble the sise. It is about one week later in maturing. but its solidity and greater size of head will make it a most valuable sort. A destrable variety either for forcing in cold frames or open ground planting. The "Big Boston"' is sure to be wanted by market gardeners and truckers, because it alway" produces large, solid, saleable heads, and will commend itself to amateurs because it heads up well at all seasons of the year, and is of criop, tender quality. Pkt. $5 c ; 0 z .10 c ; 40 z .35 ; 1 b \$ 1.25$.

Hardy Green Winter. Very hardy and forms a solid head. Pkt. $5 \mathrm{c} ; 0 z .10 \mathrm{c} ; 1 / 4 \mathrm{lb} .35 \mathrm{c} ; 1 \mathrm{~b} . \$ 1.25$.

Black-Seeded Simpson. Like the curled Simpson, this variety does not properly form a head but it is lighter in color, the leaves nearly attaining double the size of the curle 1 Simpson; it is well suited for forcing and it is one of the best for market gardeners. Pkt. $5 \mathrm{c} ;$ oz $10 \mathrm{c} ; 4 \mathrm{oz} 35 \mathrm{c} ; 1 \mathrm{~b}$. $\$ 1.25$.

Hoston Market. This is an improved variety of the Tenuis Ball, and attains a large size. It grows very compact; is white and crisp; one of the best varieties for forcing or out-deor growing. Try it. Pkt. Sc: oz. $10 \mathrm{c} ; 1$ oz. $35 \mathrm{c}$; $1 \mathrm{~b}$. $\$ 1.25$.

Now Salamander. For Summer use, forming good sized, compact heads; color light green outside, white oa inside; withstands heat. Pkt $5 \mathrm{c} ; 0 z .10 \mathrm{c} ; 4 \mathrm{oz} .30 \mathrm{c} ; 1 \mathrm{~b} . \$ 1.00$.

Prize Head or Early Brown Cabbage. Bronzed, curled. New sort. A half cabbage variety of bronzededged leaves; a beauty. Plt. $5 \mathrm{c}$; oz. $10 \mathrm{c} ; 4$ oz. $35 \mathrm{c}$; 1b. $\$ 1.25$.

Now York. A very large green Lettuce with solid beads, often weighing three to four pounds each. Not suited for forcing, buc excellent for Summer use, being slow to come to seed. Ykt. $5 \mathrm{c} ; 0 \mathrm{z}, 10 \mathrm{c} ; 40 \mathrm{z}$. $30 \mathrm{c}$; 1b. $\$ 1.00$.

No Better Seeds Can be Bought EAST or WEST.

See Page 2t-Send us your order for one of the collections.

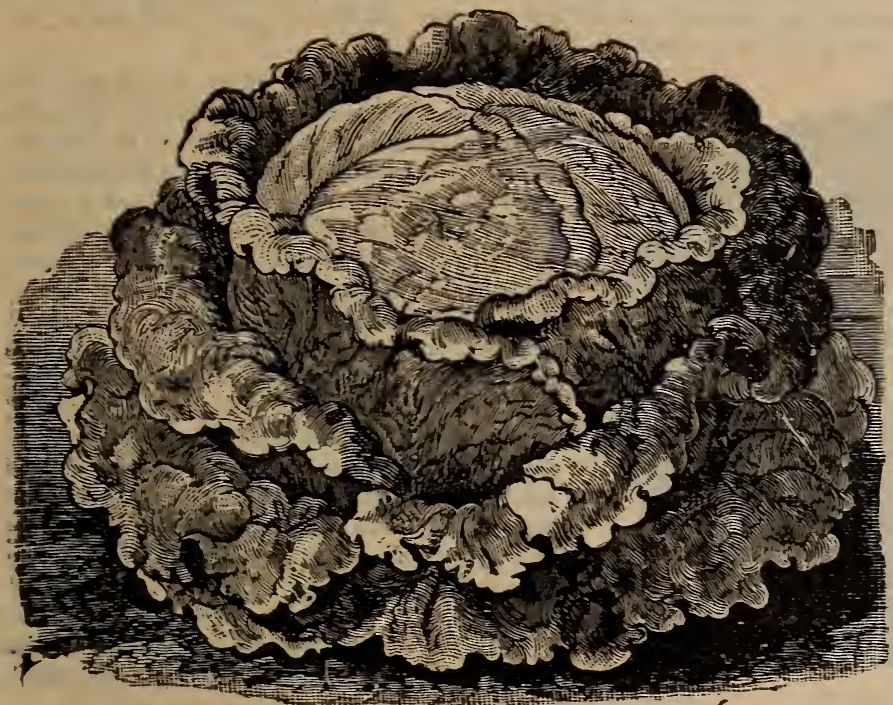

CALIFORNIA CREAM BUTTER LETTCCE.

California Cream Butter Lettuce. This forms round, solld heads of good size. The outer leaves are green, marked with small brown spots, the inner portion is a rich cream yellow and of a rich, buttery flavor, is medium early; an excellent Summer Lettuce, slow to go to seed. Pkt. $5 c ; 0 z .10 c ; 40 z 30 c$ : Ib. $\$ 1.00$.

Carly Curled Silesian. A cutting variety; earliest for outdoor planting. Does not head : affords good flavored salad long before the cabbage varieties have commenced to head. Color almost golden. Pkt. $5 \mathrm{c} ; \mathrm{oz}$. $10 \mathrm{c} ; 4$ oz. $30 \mathrm{c} ; 1 \mathrm{~b} . \$ 1.00$.

Early White-Seeded Curled Simpson. This variety does not head, but forms a compact, close mass of leaves ; for forcing and early outdoor sowing. Pkt $5 c .0 z .10 c ; 4$ oz. $35 c$; 1b. $\$ 1.25$.

\section{MELON--MUSK OR CANTALOUPE.}

\section{No Better Seed Grown in the Land.}

One Ounce of Seed for Sixty Hills; 2 to 3 lbs. for an Acre.

CULTURE.-Select a light, sandy soil, and after all danger of frost is over and the ground has hecome warm and dry, plant in hills four to six feet a part $\epsilon$ ach way, six to twelve secds to the hill. When up and all danger of insects is past, pull out all but three plants. Cultivate until the vines cover the ground, ard pinch ends of the growing shoots to induce carly fruiting. Ashes, lime. or even dry road dust is excellent to sift over the young plants when the dew is on to prevent the attack of insects. A few hills for early fruit may be had by sowing in hotbed on pieces of sod or in pots. The Seeds may also be started out of doors, under hand frames or glasses.

thatra Early Hackensack. This valuable variety is ready for market fully ten days ahead of the well. known Hackensack. which it much resembles in shape and quality. The Melons ase of good size, weighing from five to ten pounds each; excellent for market and private garden. Pkt. $5 \mathrm{c} ; 0 z .10 \mathrm{c}$; $10 z .20 \mathrm{c} ;$ ib. $60 \mathrm{c}$

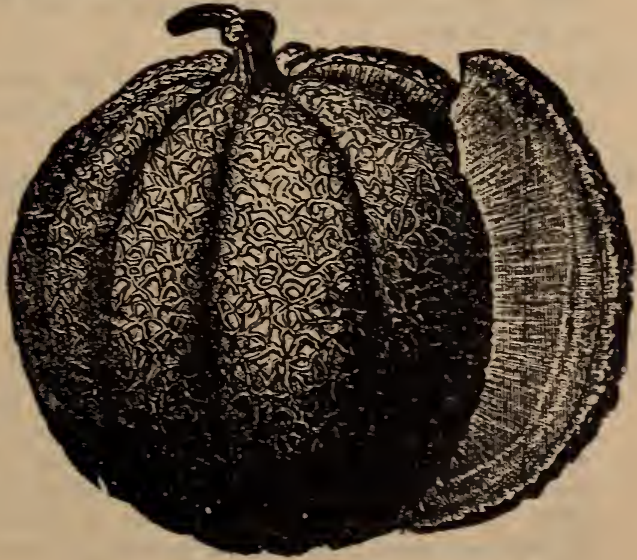

NEW, RXTRA EARLY HACKENSACK. 


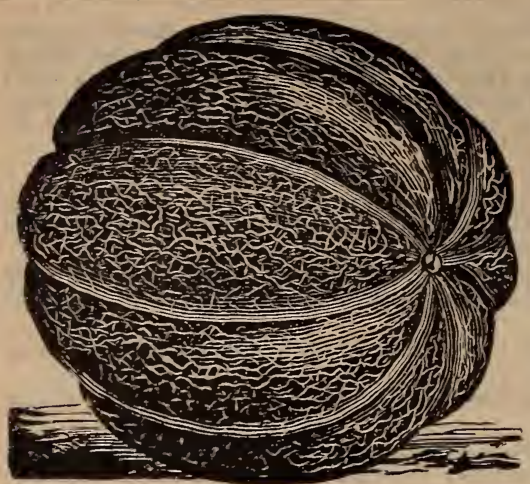

EXTRA FARLY CITRON NUTMEG.

Extra carly Citron Nutmeg. The first in the market, the largest of the very early. A decided acquisition among the Can ${ }^{-}$ taloupes. Ten days earlier than any other, fair size and of fine flavcr. A variety which for its early maturity will be found profitable by all Market Gardeners, also in the private garden till others come into condition. Pkt. $5 \mathrm{c} ; 0 \mathrm{z} .10 \mathrm{c} ; 4$ oz. $20 \mathrm{c} ; 1 \mathrm{~b} .60 \mathrm{c}$.

Paul Rose. This new Melon is a cross between Osage and Netted: Gem. combining the sweetness of the former and the netting of the latter. Is a SALMON fleshed small sized Melon and surpassses all others as a shipper and long keeper. It has thick flesh and small seed cavity, and is bound to rank first as a Market Gardeners' favorite. Do not fail to buy some seed and give it a trial. Pkt. $5 \mathrm{c} ;$ oz. $10 \mathrm{c} ; 4$ oz. $30 \mathrm{c} ; 1 \mathrm{~b} . \$ 1.00$.

Netted Beauty Mask Melon.This new variety of recent introduction has met with large sale. Its great earliness, distinct, hándsome appearance and productiveness, has made it a favorite with all who gave it a trial. The whole crop averaged the past two seasons ten melons to a vine on good ground. Pkt. $5 \mathrm{c} ; 0 \mathrm{z} .10 \mathrm{c} ; 3 / 4 \mathrm{lb}, 20 \mathrm{c} ; 1 \mathrm{~b} .65 \mathrm{c}$.

Long Yellow Cantaloupe. Yellow flesh. Very fine. Pkta5c; oz. 10c; 4 oz. 20c; lb. 60c.

Emerald Gem. Medium size, nearly round, flesh a delicate light salmon color, very thick, fine grained and of mosi excellent flavor. The sind is thin dark green, ribbed, but not netted, very early and one of the best for home use. Pkt. $5 \mathrm{c}$ : oz. $10 \mathrm{c} ; 1 / 4 \mathrm{lb} .20 \mathrm{c} ; 1 \mathrm{~b} .60 \mathrm{c}$.

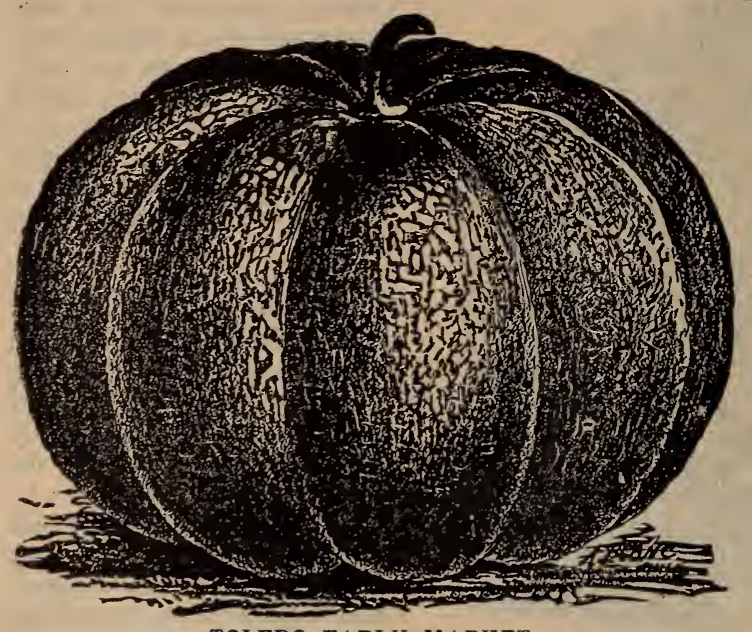

TOLEDO EARLY MARKET.

Montreal Market. Excellent variety of the largest size. We have had them weighing twenty pounds. In shape almost round, flattened at both ends, deeply ribbed, skin green and netted, flesh green. Pkt. $5 \mathrm{c}$; oz. $10 \mathrm{c}$; $1 \mathrm{~b} .60 \mathrm{c}$.

Tip Top. Smoothskin. Flesh yellow and very sweet. An excellent shipper and a tip top Melon in every way, Pkt. 5c; oz. 10c; $1 / 4$ 1b. 20c; 1b. 60c.

Baltimore Nutmeg Cantaloape. A Me'on of high repute in Philadelphia and Baltimore. Is showy' pointed at both ends, strongly netted, green fleshed, fine flavored, productive and a good shipper. Pkt. $5 \mathrm{c} ; 0 \mathrm{z} .10 \mathrm{c} ; 4$ oz. 20c; 1b. 60c.

Miller's Cream. Ranks high as a market Melon, either for home or shipping, The flesh is of a rich salmon color, very sweet and melting, and is so thick that the Melon is almost solid, the seed cavity being re markably small. A strong grower and very productive, and covers the ground with beautiful solid fruit. This Melon is undoubtedly one of the best flavored and most profitable for market or private ga rden. Pkt. $5 c$; oz. $10 c ; 3 / 41 b .20 c$; 1b. $50 c$.
Toledo Early Market. This fine Melon has been in our market for many years, cultivated and sold by our Market Gardeners of long experience, especially successful as Melon growers, in $\mathbf{w}$ hich no little skill is required, as market men well know, The seed was successfully controlled by a few gardeners, for the reason that they could market them two weeks earlier than others and at higher prices. They have sold this Melon as high as $\$ 30$ ) per dozen to our markets and commission houses. Is a type of the famous Chicago Market Musk Melon, equal to it in quality, which we hold to be of the VERY SWEETEST and MUCE LARGER and very productive. It is d. cidedly ribbed, extra well netted, with very thick green flesh. We managed to purchase some of the true seed of this grand Melon and offer it at a moderate price. As our supply is not large, we advise our friends to f 8 or us with their orders at as early a date as possible. Pkt. $5 \mathrm{c} ; 0 \mathrm{x}, 10 \mathrm{c}$; oz. 25c; 1b. 75c.

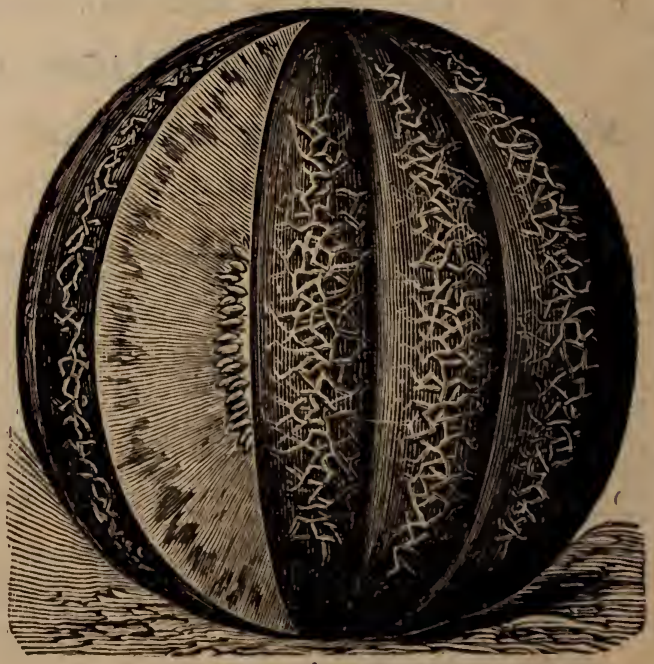

MILLER'S CREAM. 


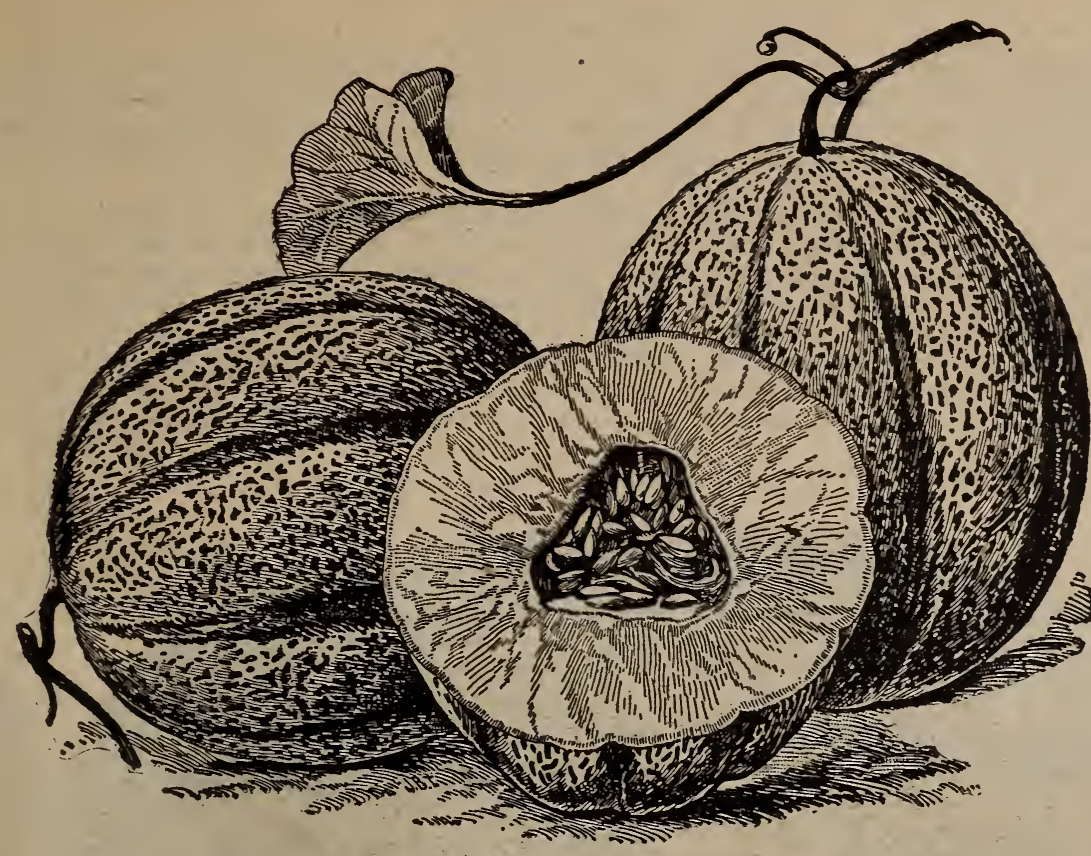

ROCKY FORD.

Rocky Ford. The most popular of all Musk Melons for marketing in baskets. Fruit isma11, oval, slightly ribbed, densely covered with net ing. Flesh thick, green, very sweet and highly flavored. This is the Melon of the West and so eagerly sought for by hotel and restaurant landlords. Pkt. $5 \mathrm{c}$; oz. $10 \mathrm{c}$; 4 oz. $30 \mathrm{c}$; Ib. $\$ 1.00$.

The Prinoess. Nearly round in shape, with heavy netted dark green skin, flesh of a rich salmon color, and thicker than in any other Melon,

very sweet and luscious in flavor, ripens early and grows to a good size. Pkt. $5 \mathrm{c} ; 0 z .10 \mathrm{c} ; 4$ oz. $20 \mathrm{c} ; 1 \mathrm{~b} .60 \mathrm{c}$.

Musk Molon Seed in Mixed Lots of 5 pounds, 10 cents per pound less.

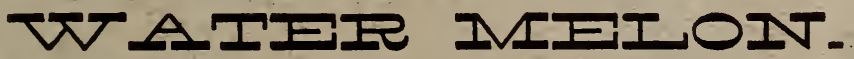

THE BEST FRUIT THAT GROWS.

One Ounce will plant about 50 hills, and 4 pounds will plant an acre.

COLTURE.-Treat the same as Musk Melon, except that they should be planted eight or ten feet apart, according to variety.

Kolb Gem, Extra Northern grown. Large, bright, red flesh, of fine quality and a good shipper. Pkt. $5 c$; oz. $10 \mathrm{c} ; 4$ oz. $20 \mathrm{c}$; lb $50 \mathrm{c}$.

Peorless Improved. Of medium size. thin rind, light mottled green. flesh bright scarlet, solid to center, crisp, melting, and sweet as honey. Pkt. 5c. 0z. 10c. 4 oz. 2nc ; 1b. 50c.

Improved Ice Cream. True. (White seed). Rind light green, flesh scarlet, solid and delicious, enormously productive, of unexcelled quality. Pkt. $5 \mathrm{c} ; 0 \mathrm{z} .10 \mathrm{c} ; 4 \mathrm{oz} .20 \mathrm{c} ; 1 \mathrm{~b} .50 \mathrm{c}$.

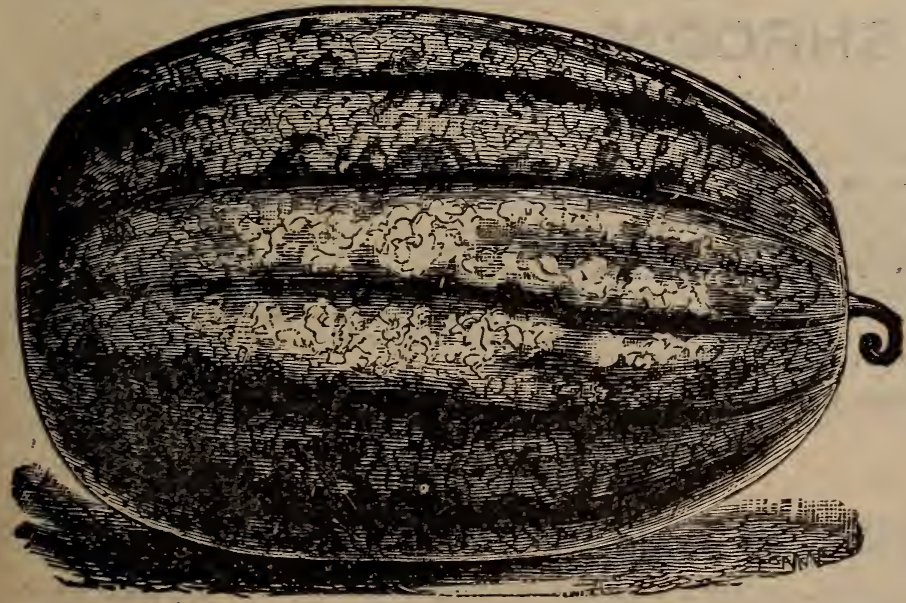

CUBAN QUEEN.
Phinney. Extra early market. The first to ripen, and of fine quality, red flesh. Pkt. 5c; oz. 10c: 4 oz. 20c; 1b. 50c.

Black Spanish. Large, round. ish. nearly black, dark red flesh, early. Pkt. 5c; oz. 10c: $4 \mathrm{oz} 20 \mathrm{c}$; 1b. 50c.

Caban Queen. Selected. This magnificent and distinct Melon is certainly one of the largest and finest varleties ever introduced Try it. Pkt. $5 \mathrm{c}$; oz. $10 \mathrm{c} ; 4$ oz. $20 \mathrm{c}$; 1b. $50 \mathrm{c}$.

The Boss. The most delicious. A new, handsome, early, :oblong variety, of nearly the same thickness throughout, skin very dark, flesh deep scarlet, sugary, melting and of excellent flavor. Pkt. $5 \mathrm{c}$; oz. 1Uc; 4 oz. 20c; 1b. 50c.

Improved Mountain sweet. Oblong dark green, rind thin, flesh red, solid, sweet. Pkt. 5c; oz. 10c; 4 oz. $80 \mathrm{c}$; ib. 50 c. 
WATER MELON-CONTINUED.

Improved Long Dixie. Selected. A new Water Melon of excellent merits and recommerded as the best shipping Melon grown, being larger, earlier and more productive than the Kolb Gem, which has heretolore been considered the best Melon for shipping. It is of very fine appearance, a darker green than the Kolb. more beautifully striped. Ionzer and extremely hardy; its eating quality is unexcelled. We have the genuive stock. Pkt. $5 \mathrm{c} ; 0 z .10 \mathrm{c} ; 4 \mathrm{oz} .20 \mathrm{c} ; 1 \mathrm{~b} .50 \mathrm{c}$

Hungarian Honey. A perfect globe-shaped Melon of medium dark green color, sweet as honey. A firstclass market garden Melon; very early; flesh brilliant red. Pkt. $5 \mathrm{c}$; oz. $10 \mathrm{c} ; 4 \mathrm{oz} .20 \mathrm{c}$; 1b. $50 \mathrm{c}$.

8weet Heart. Has no equal as a shipping Melon. Vine vigorous and productive, ripening its fruit easly. Fruit large, oval, very heavy, uniformly mottled, very light green, rind thin, but firm; flesh bright red, firm, solid, but very tender, melting and sweet. Pkt. $5 \mathrm{c} ; 0 \mathrm{z} .10 \mathrm{c} ; 4 \mathrm{oz} .20 \mathrm{c} ; 1 \mathrm{~b} .50 \mathrm{c}$.

Fordhook Early. New, of lale introduction; an extra early sort of large size, averaging in weight 35 lbs. : excellent quality. Don't fail to try same. Pkt. $5 \mathrm{c}$; oz. 10c; 4 oz. 20c; 1b. 60c.

Preserving Citron. Red Seed. Used in making sweetmeats and preserves; flesh solid white. Pkt. $5 \mathrm{c}$ oz. 10c. : 4 oz. $20 \mathrm{c} ; 1 \mathrm{~b} .60 \mathrm{c}$.

Lots of five pounds and upwards ten cents per pound less.

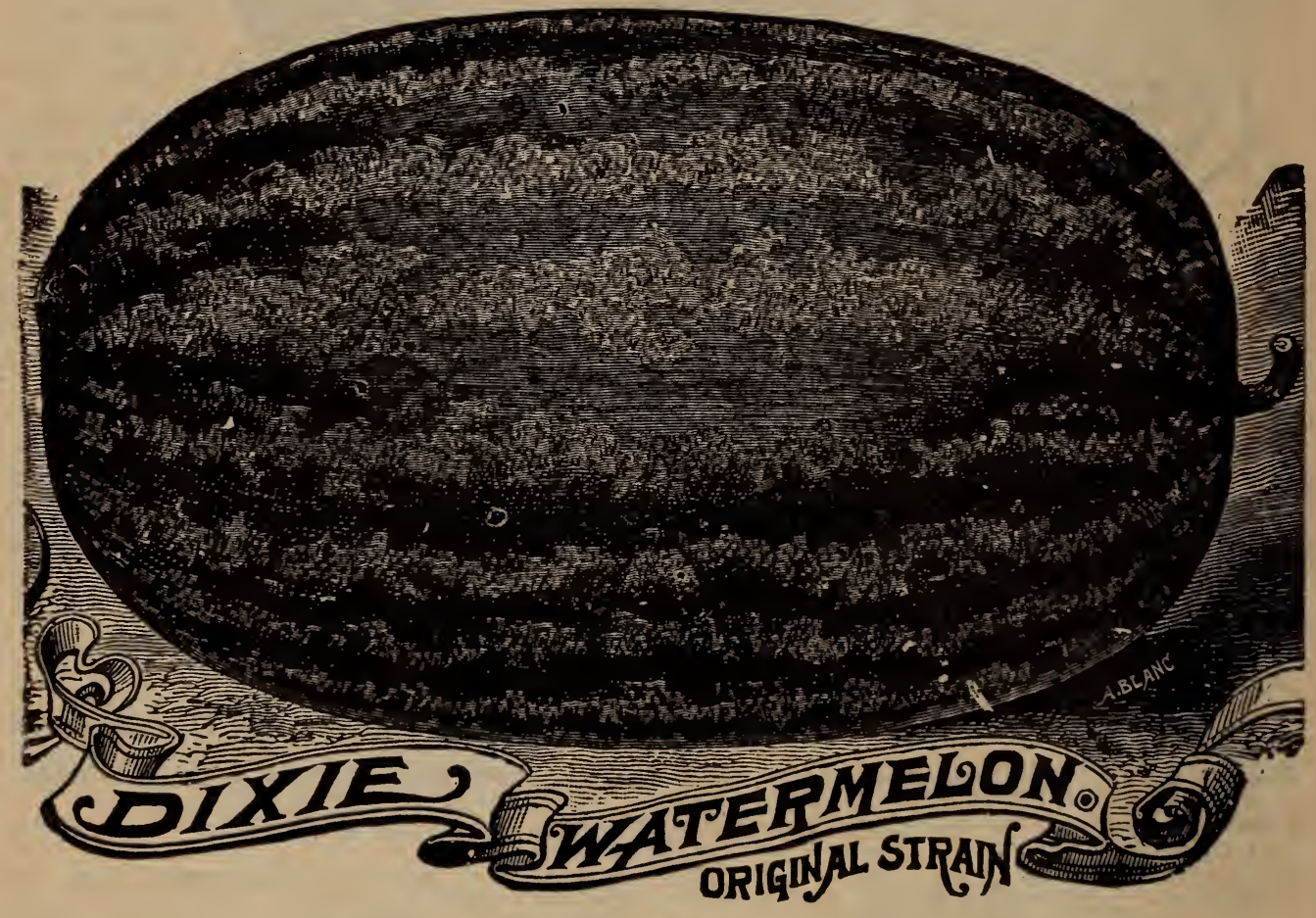

\section{MUSHROOM SPAWN.}

COLTURE.-Mushrooms can be grown in any dark room or cellar where the temperature can be kept at 50 to 60 degrees. From some old pasture procure good rich ooil and store it away. To every bushel of this soll add two bushels of fresh horse manure. Of this well-mixed compound orepare a bed, say four feet wide. Put down a thin layer and pound it down hard, and go on until you have a bed 18 or 18 inches thick. It soon be. comes pretty hot, but let the heat recede until it is only 85 or 90 degrees. Then make holes, say a foot apart, and put in the spawn, two or three pieces as large as a walnut to each hole. Cover the holes and press the soil solin and smooth. Let the bed remain in this condition about twelve days, then cover the bed with two inches of fresh loam, and over this put four or five inches of bay or straw aod the work is done If the temperature is right, in six or eight weeks you may expect Mushrooms. The beds will continue bearing from twenty to thirty

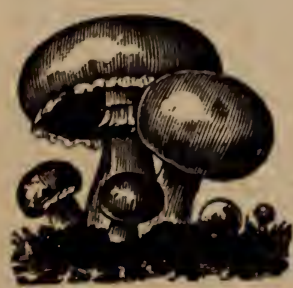

MU8HROOM8. days. After the first crop is gatherel, spread over the bed an inch of fresh soi). moistened with warm water, and cover with hay as before. The main conditions in Mushroom growing are proper and uniform temperature and rery rich soil. One brick of spawn is sufficient for $a$ bed $2 \times 6$ feet.

ENGLISH SPA W.-Single Brick, 20e; 12 Bricks, $\$ 1.50$.

\section{OKRA, OR GUMBO.}

CULTURE. - Select rich soil and plant when ground becomes warm. The pods used to thicken soup, being gathered when young.

Dwarf Prolific. Of dwarf habit and an abundant bearer: with long green slender pods: the best sort in use. Pkt. Kc: $02.10 \mathrm{c} ; 1 / 61 \mathrm{~b} .25 \mathrm{c}$. 


\section{OUR PEDIGREE DOUBLE TESTED ONION SEED.}

Write for Special Prices on 25 Ibs or over, naming the varieties you want. We offer special inducements

to those wanting a Seed Drill or Cultivator, with seed enough to sow an acre. We are headquarters

for Onion Sets, and will sell you first-class sets at the very lowest prices.

Good Onion Seed is of the Utmost Importance. Fully realizing this, we have for some years made a SPECIALTY OF ONION SEED, and have all our crops raised under special contract, subject to careful supervision. Our Onion Seed ALL GROWN FROM CBOICE SELECTED BULBS, are critically examined before being set out for seed. In quality it is far superior to much that is put upon the market, often grown by persons too inexperienced or too careless to select fine, well-shaped bulbs. In vitality it is VERX STRONG, being CAREFULLY TaSTED. The very rapid increase in our Onion Seed trade, particularly among market gardeners, many of whom order one hundred and more pounds, is the very best evidenoe that our Onion Seed is UNEXCELLED in QUALITY.

CULTURE.-One ounce to 100 feet of drill, four to five pounds to the acre. The Onion thrives in a rather deep, rich, loamy soil, and unlike most vegetables, succeds well when cultivated on the same ground for suc, cessive years. As early in the Spring as the ground is in working order commence operations by levelling the ground with a rake, and tread it firmly; sow thinly in drills about a quarter of an inch deep and a foot apart. cover with fine soil, press down with the back of a spade or light roller. If grown to make large Onions, thin plants gradually, so that they stand two or three inches apart. Keep the ground free from weeds by frequently hoeing, taking care not to stir the ground too deeply.

HOC YOU GTOW FULL-SIZED ONIONS THE FIRST YEAR FROM OOR BLACK SEED; for thls purpose four or five pounds of seed per acre are required. To raise small sets, forty to fifty pounds of seeds are required per acre, and for this purpose the best rarieties are the Yellow Danvers, Yellow Strasburg, Early Red and White Silverskin.

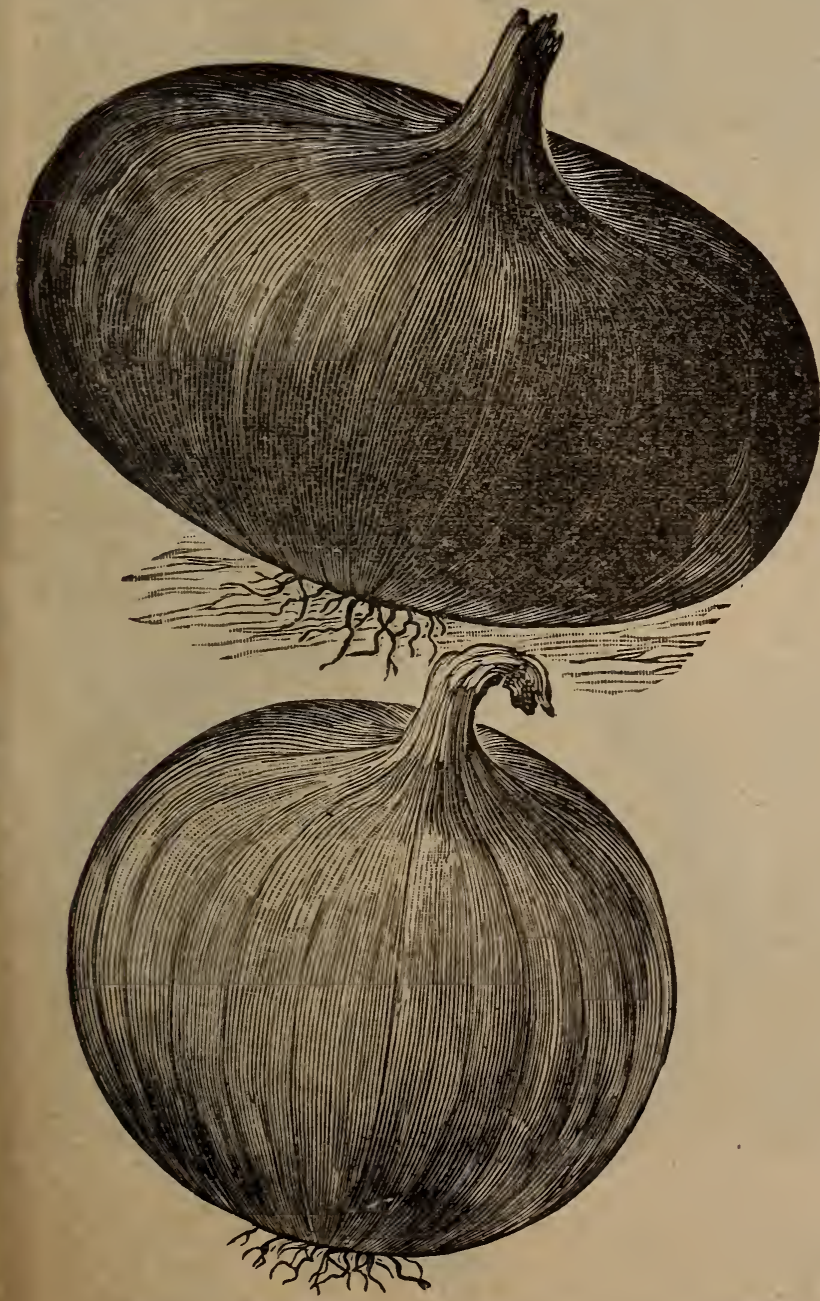

LARGE RED WETHERSFIELD AND YELLOW GLOBE DANVERS.
Large Red Wethersfield. The most profitable Red Onion for the market gardener, as it is the heaviest yielder, 600 to 800 bushels having been frequently harvested upon a single acre from seed sown in the Spring. It grows to good size, single Onions often weighing from one to two lbs. apiece. In short, it is the best Red main crop Onion for everybody. Our strain ${ }_{-c}^{-1}$ lunsurpassed, the seed we offer having been saved from the largest: Onions of perfect shape and deepest color, Pkt, 5c; oz. 10c; 4 oz. 30 ; 1 b. $\$ 1.00$.

Extra Early Red. Smaller than Red Wethersfield, and about Iten days earlier; color, beautiful deep red. Give it a trial. Pkt. $5 \mathrm{c} ; \mathrm{oz} .10 \mathrm{c} ; 4 \mathrm{oz}$. $30 \mathrm{c} ; 1 \mathrm{~b} . \$ 1.00$.

Southport Early Red Globe. Grown by us from selected bulbs. Thls is a very, handsome variety, and is deserving of general cultivation. It matures early, grows to a medium size, skin deep red: flesh fine grained, mild and tender. Pkt. $5 \mathrm{c} ; \mathrm{oz}$. $15 \mathrm{c} ; 4$ oz. $50 \mathrm{c}$; lb. $\$ 1.50$.

Early Flat Yellow Danvers. Different from the Globe strain only in shape, being more flat. A splendid Onion for the market or hcme use ; sells readily in the market. Very productive, Pkt. 5c; oz, 10c; 4 oz, $30 \mathrm{c} ; 1 \mathrm{~b} . \$ 1.00$.

Yellow Dutch or Strasbug. One of the oldest varieties, a good keeper, used largely for growing sets as well as for market. Pkt. 5c; oz. 10c; 4 oz. $30 \mathrm{c}$; $1 \mathrm{~b}$. $\$ 1.00$.

If there Is anything in the Seed or Implement line that you want and do not find listed in this Calalogue, write us and we.will try to get it for you. 


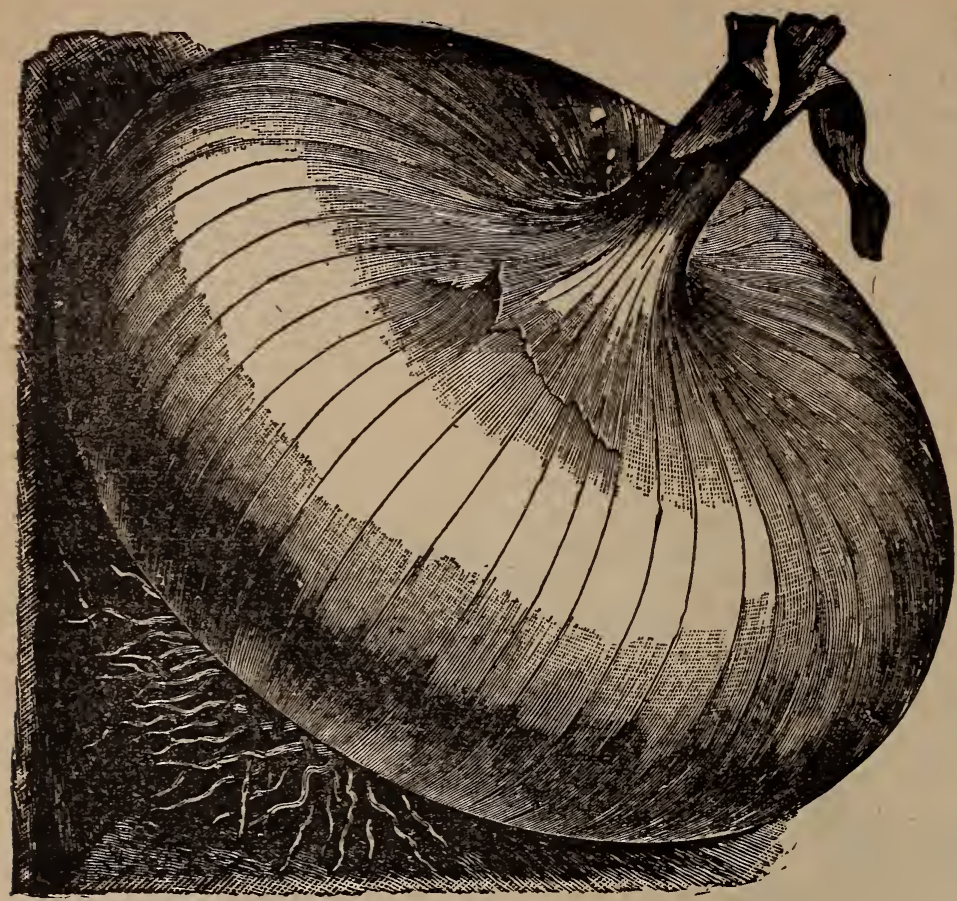

MAMMOTH SILVER KING ONION.
Mammoth Silver King Onion. This mammoth variety is one of the largest in cultivation, averaging from 15 to 22 inches in circumference and of ten weighing $21 / 2$ to 4 pounds each It matures early and is of uniformly large size and fine shape, being flattened, but thick. The skin is of a beautiful silver white, flesh snowywhite and tender, of a mild, sweet flavor. We know of no variety of this vegetable that has attracted so much attention as this. Its large size and handsome appearance, as well as mild flavor, recommend it for exhibition at fairs, for the fancy market as well as the home table Pkt. $5 c$; oz. $\mathscr{Z C}$; $/ / 4$ 1b. $60 \mathrm{c} ; 1 \mathrm{~b} . \$ 2.00$.

Yellow Globe Danvers. Extra selected. Extensively grown as a main crop, true globe-shaped variety, beau tiful golden color, very productive, a first-rate reeper and shipper, the best and most profitab'e market sort. Our seed cannot fail to please. Pkt. $5 \mathrm{c}$; oz. $10 \mathrm{c}$; 4 oz. 30 c ; 1b. $\$ 1.00$.

\section{Read over our Potato Price List, page 41. See what we offer in the way of Incubators, page 77. Do not be afraid to order. We deal fairly.}

Our Northern Ohio Yellow Globe Onion. Fancy Lake County selected stock. Generally a amitted by Onion growers everywhere to be the most desirable strain and perfect type of globe.shaped Onion in existence. We name it Northern Ohio Globe to distinguish it from the many strains of Globe Danvers now offered. It represents the product of years of careful selection and cultivation, this. the finest strain of that popular type of the Yellow Globe Danvers Onion, which intelligent, painstaking care can produce. It is immeasurably superior to the average seed offered, not only in shape aud color, but in productiveness. Its main points of excellence are : distinct and at tractive shape, handsome. bright, even color, it ripens early and all at once. The necks are very small and cure almost down to nothing. The firm solid bulbs are excellent winter keepers and all that can be desired in size and quality; enormous yielders, 900 bushels (standard weight) per acre are frequently grown on rich onion land. This is a superb onion for all claeses of soll (when well enriched) and especially good for marsh lands, on arcount of its quick maturiy $g$ qualities. Try this big money maker. Pkt. $5 c ; 0 z .15 c ; 1 / 41 b .50 c ; 1 b . \$ 1.50$.

Southport Large White Globe. Large strain of globular shape, white skin, a gooa keeper, commands the higheat market price. Pkt. $5 \mathrm{c}$; oz. $15 \mathrm{c} ; 1 / 4 \mathrm{lb} .60 \mathrm{c} ; 1 \mathrm{~b} . \$ 200$.

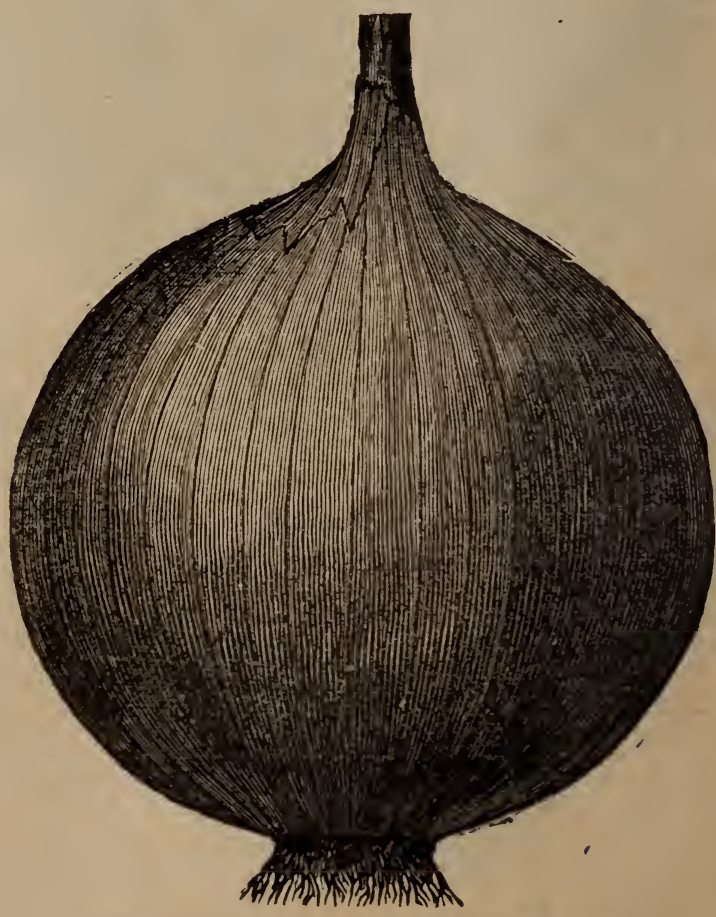

NORTHERN OHIO YELLOW GLOBE'ONION. 


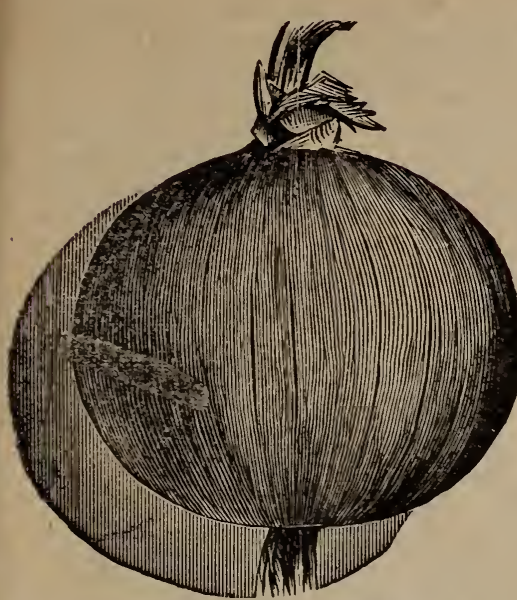

White Portugal, or Silver skin. very desireble for family use, a good keeper, flavor mild and pleasant. skin silvery white, of handsome appearance, bighly esteemed for pickling when young, also for market in early winter. This is the variety of which White Onion Sets are grown. Pkt. $5 \mathrm{c} ; \mathrm{oz} .15 \mathrm{c} ; 1 / 4 \mathrm{lb}$. $60 \mathrm{c} ; 1 \mathrm{~b} . \$ 200$.

American Extra Early Pearl. This is among the earliest, if not the earliest, of White Onions. Keeps well. Of a fine, showy, waxy appearance, the flesh is snow white, flavor mild and pleasant, grows|five to six inches in diameter the first year from seed. Pkt. $5 c$; oz. $20 \mathrm{c} ; 1 / 4$

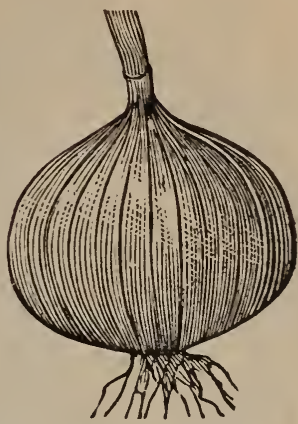

AMERICAN EXTRA EARLY PBARL.

WHITE PORTUGAL, OR SIT VER SKIN ONION. lb. 20 ; ; 1b. 75 c.

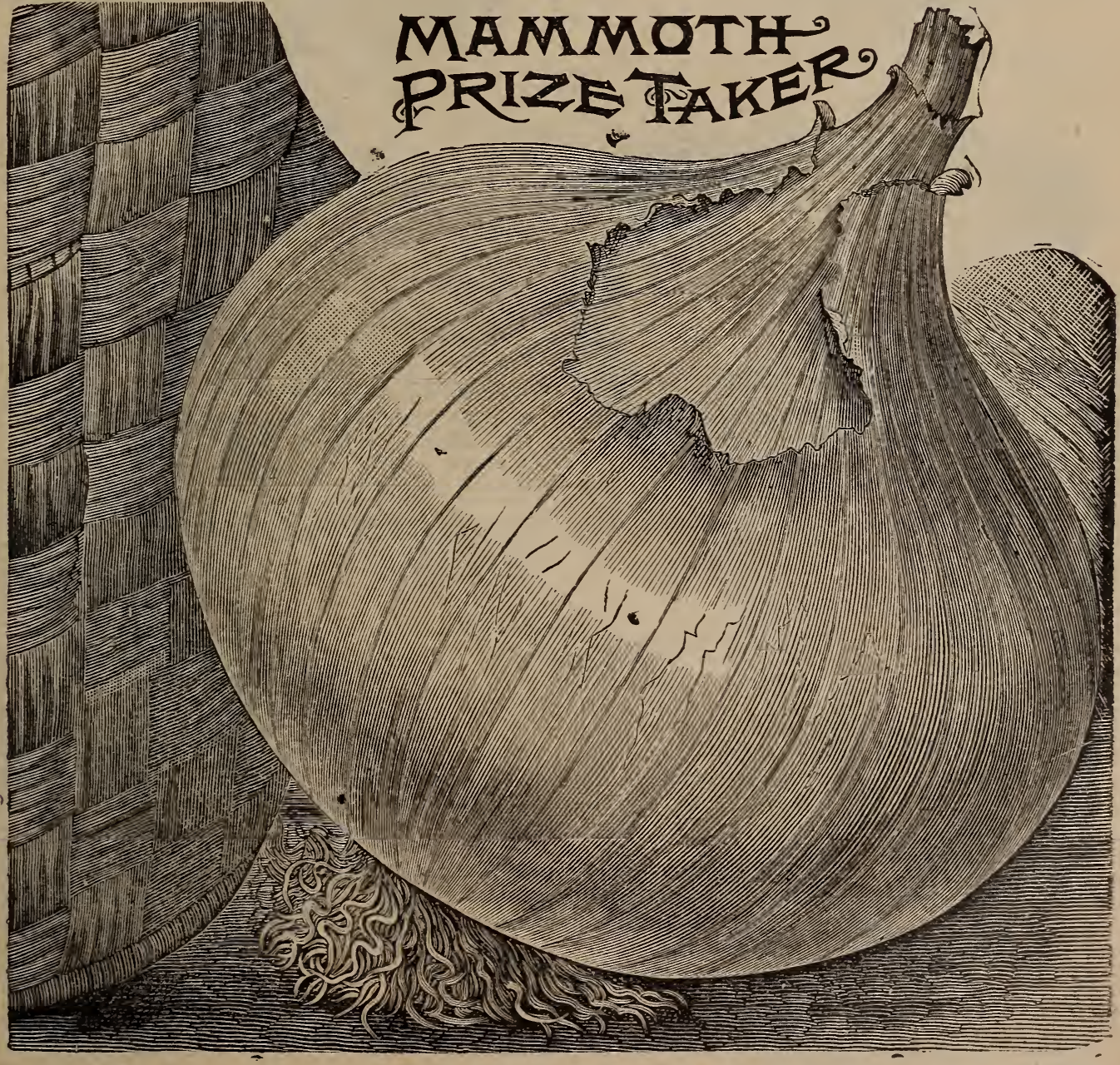

The Prize Taker. Genuine American grown. The handsomest, largest Yellow Globe Onion. A new variety introduced a few years ago, which has proved to be an excellent keeper, of fine flavor, handsome shape and enormous size, many single Onions having been raised to weigh five pounds and over from seed the first year. It is of the same type as those immense imported onlons which can be seen in fruit stores and always command a very high price. The Prize Taker grows always to a perfect globe shape, with a bright straw-colored skin; the necks are very small, and the Onions always ripen up hard. Pkt. $5 \mathrm{c}$; oz..20c; K:1b. $45 \mathrm{c}$; 1b. $\$ 1.40$. 


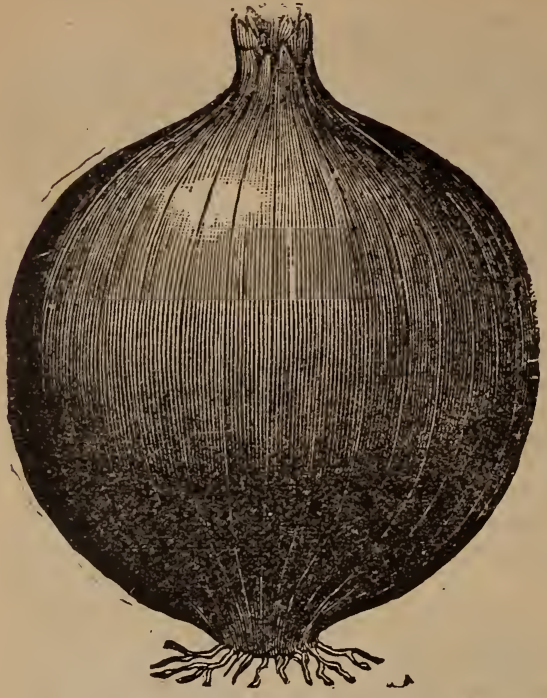

SOUTHPORT LARGE YELLOW GLOBE.

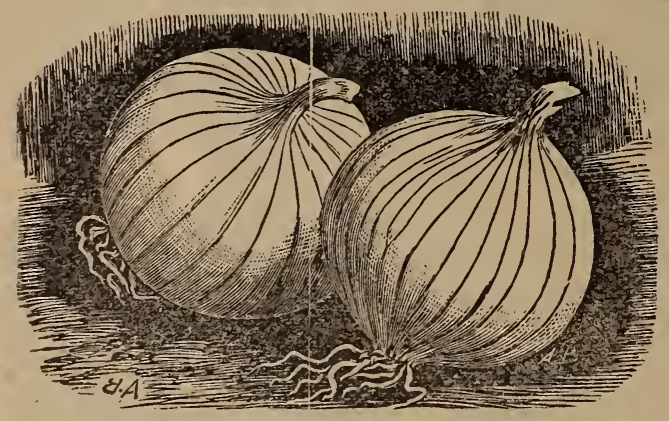

ADRIATIC BARLETTA.
Southport Large Yellow Globe. Beautiful in shape and size, maturing a few days later than the Red Wethersfield. It is a splendid keeper and in quality is superior to most other varieties. Pkt. $5 \mathrm{c} ;$ oz. $15 \mathrm{c} ; 1 / 4 \mathrm{lb} .40 \mathrm{c} ; 1 \mathrm{~b} . \$ 1.25$.

New Giant Rocca. Light red. These Onions are of large size, handsome appearance, and mild, delicate flavor, of beautiful round form, the outer skin bright red, while the flesh is white, mild and pleasant. Pkt. $5 c ; o z, 15 c ; 1 / 41 b .40 c$; 1b. $\$ 1.40$.

Early Neapolitan White. A very early small flat white Onion, highly exteemed for pickling and largely grown by gardeners to furnish their customers with early pickling Onions. Pkt. $5 \mathrm{c}$; oz. $15 \mathrm{c}$; $1 / 4 \mathrm{lb} .50 \mathrm{c} ; 1 \mathrm{~b} . \$ 1.75$.

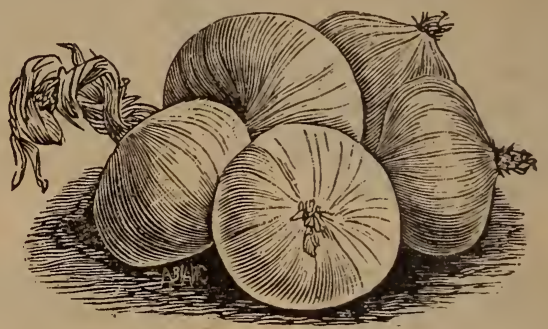

EARLY PARIS SILVER WHITE.

Early Paris Silver White. One of the earliest varieties; small, white and beautiful; valuable for an early bunch Onion, also much used as a pickling variety; popular with the Paris market men. Pkt. $5 \mathrm{c} ; 0 z .20 \mathrm{c} ; 1 / 4 \mathrm{lb} .60 \mathrm{c} ; 1 \mathrm{~b} . \$ 2.00$.

Adriatic Barletta. A very early, small. pure white variety, having a very delicate silver skin, flesh flrm and mild in flavor. Its great merit is its extreme earliness. For pickling purposes it is unexcelled. Pkt. $5 \mathrm{c}$; oz. $20 \mathrm{c} ; 1 / 4 \mathrm{lb}$ lb. 60c; 1b. $\$ 2.00$.

White Queen. Remarkable for its extreme earliness and very mild flavor; it is small and white skinned, much liked for pickling. Pkt. $5 \mathrm{c}$; oz. $20 \mathrm{c} ; 1 / 4 \mathrm{lb} .60 \mathrm{c}$; 1b. $\$ 2.00$.

\section{NORTHERN OHIO AND PENNSYLVANIA GROWN, WHITE AND YELLOW ONION SETS}

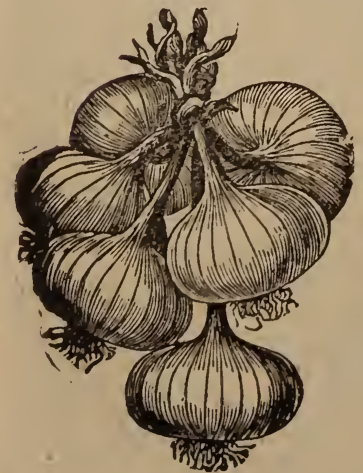

ONION SETS.

CULTURE.-They should be planted out as early in Spring as the ground is dry enough to work. Bottom sets are produced by sowing the seed as early as the ground can be worked in Spring, very thickly in beds or drills, at the rate of 50 lhs. per acre. One quart of sets to 30 feet in drills; 8 to 12 bushels, depending on size, to set an acre in drills. EXPRESS OR FREIGHT CBARGES 10 BE PAID BY THE PURCHASER. On account of the early publication of this Catalogue we cannot guarantee prices given, but to avoid unnecessary delay in writing, we will fill orders sent, and will give as many as the money sent will pay for. Prices may be lower or higher.

Yellow Onion Seed or Bottom Sets.

Quart. Peck. Bush. White Onion Seed or Bottom Sets. $\$ 015$ Shallots or. Yellow Multiplyers. White Multiplyers. Egyptian or Perennial Tree Onion Sets $80 \quad \$ 250$ $20 \quad 100 \quad 350$ $75 \quad 250$ $100 \quad 350$ 50150 postage

Wa If Orior sets are wented tc, be sent by mail, 10 cents per quart or pound must be added to prepay

Bottom Sets and Potatol Onions are sold by measure; White Multiplyers, Button and Egyptian by weight, 28 pounds for a bushel.

We sell full-sized packets. No half sizes to be had. Send us your order. 


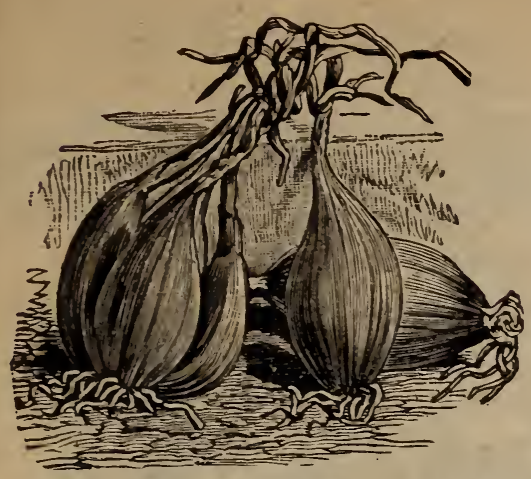

SHALLOT OR YELLOW MOLTIPLIERS.

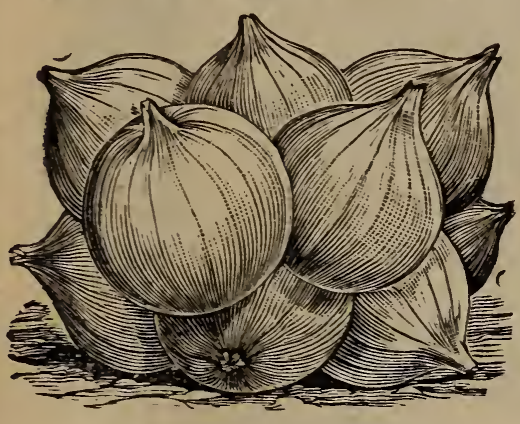

WHITE MOLTIPLYERS.

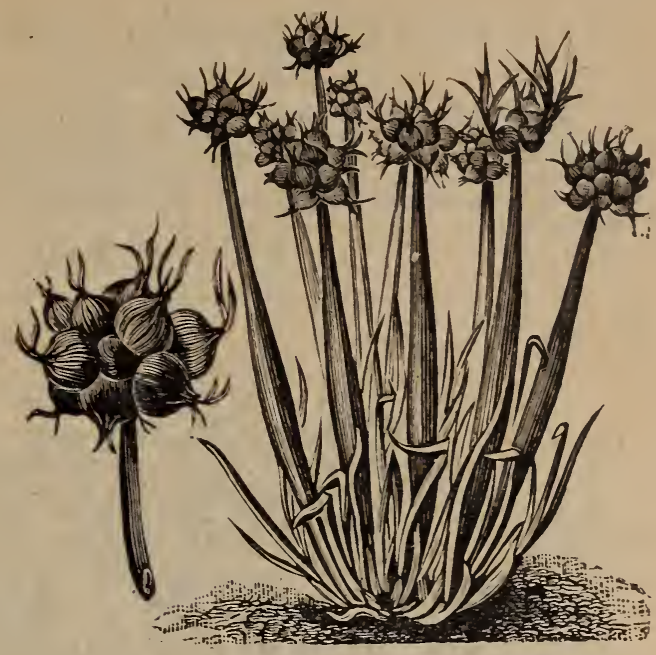

WINTER OR EGYPTIAN TREE.

Winter, or Egyptian Tree. When once set out they grow for years without any protection or care, except in keeping down the weeds. They start so early in the Spring that they are ready for use a long time before any other Onions can be had. Are mild fla. vored sweet and tender. They form no large bulbs, but divide and grow as many as 15 or 20 small Onions in one bunch. Desirable for family use and very early and profitable for market gardeners.

White Multiplyers. Are of a pure silvery white color, enormously productive, frequently producing as many as twenty bulbs in a single cluster from a single bulb planted, of excellent quality and size for bunching green, or can be ripened for use in pickling Onions. Their keeping qualities are remarkable, but their most important quality is their extreme earliness, being ready for market from three to four weeks ahead of other Onion Sets.

We are headquarters for Onion Sets and sell cheap by the peck, bushel or barrel. We will quote SPECIAL PRICES on large lots.

\section{PARSLEY.}

CULTURE.-Parsley succeeds best in rich mellow soil. As the seeds germinate very slowly three or four weeks lapsing sometimes before it makes its appearance, it should be sown early in Spring, previously soaking the seed for a few hours in tepid water. Sow thickly In rows a foot a part and half an inch deep. For winter use protect in a frame or light cellar, or a few plants may be placed in pots or boxes and kept in the house for convenient use during the winter.

Extra Double Curled. A curled variety for garnishing. Pkt. 5c; az. $10 \mathrm{c} ; 1 / 4 \mathrm{lb} .15 \mathrm{c} ; 1 \mathrm{~b} .50 \mathrm{c}$.

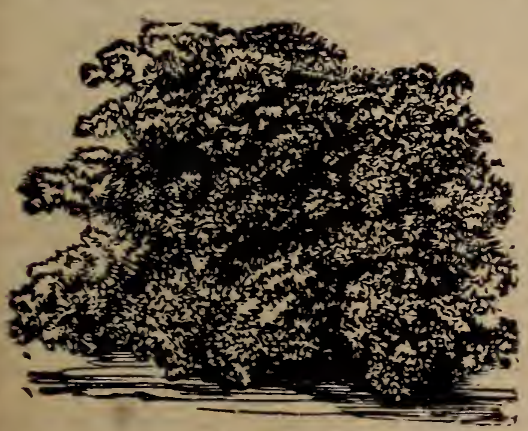

MOSS CURLED PARSLEY.

Champion Moss Curled. Leaves crimped and curled like a bed of moss, giving a most beautiful decorative appearance. Pkt. 5c ; oz. $10 \mathrm{c} ; \mathrm{y} / \mathrm{lb}$. $20 \mathrm{c}$; 1b. $75 \mathrm{c}$.

Plain or Single. Dark green, with plain leaves; very hardy. Pkt. $5 \mathrm{c} ; 0 \mathrm{oz} .10 \mathrm{c} ; X_{1 \mathrm{lb}}$. $15 \mathrm{c} ; 1 \mathrm{~b} .50 \mathrm{c}$.

Eamburg. or Turnip Rooted. A very popu'ar variety in Europe. Fine, fleshy vegetable roots which are used in soups, etc. Pkt. $5 c ; 0 z$. $10 \mathrm{c} ; \mathrm{z} / \mathrm{1b}$ 1 $15 \mathrm{c} ; 1 \mathrm{~b} .50 \mathrm{c}$.

\section{PARENIPS.}

CULTURE,-SOw as early in Spring as weather will admit. Cultivate similar to carrots.

Long 8mooth White. No side roots; tender and excellently flavored. Pkt. $5 \mathrm{c}$; oz. $10 \mathrm{c} ; 4$ oz. $15 \mathrm{c}$; 1b. $40 \mathrm{c}$.

Large Improved Sugar or Bollow Crown. The best variety in cultivation; roots long, white, smooth, tender, sugary; excellent flavor. Pkt. $5 \mathrm{c} ; 0 z .10 \mathrm{c} ; 4 \mathrm{oz} .15 \mathrm{c} ; 1 \mathrm{~b} .40 \mathrm{c}$.

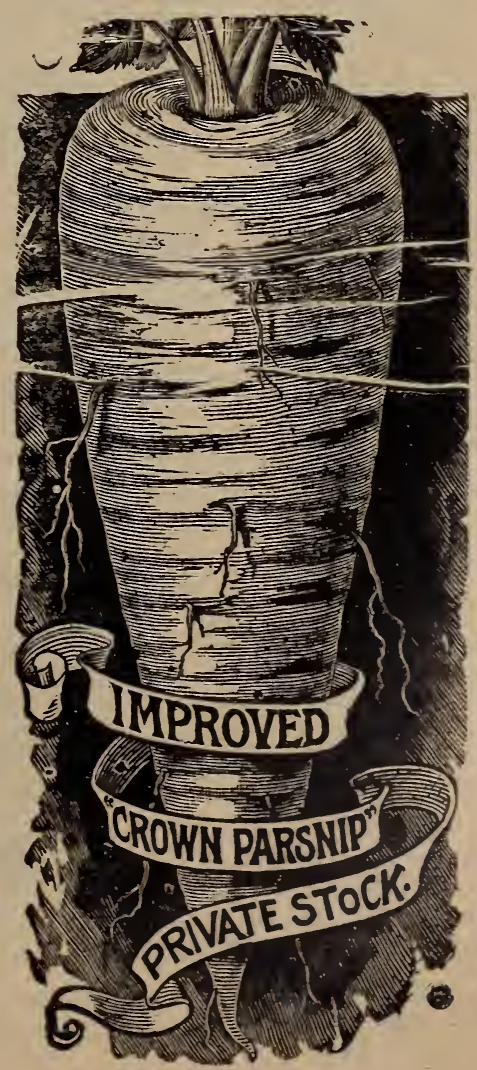




\section{EXTRA EARLY MARKET GARDEN PEAS.}

One pound will plant about 50 feet of drill, from one to two bushels per acre.

CULTURE. - The Pea comes earliest to maturity in light, rich soil. For general crops a deep loam or a sol: atrongly inclined to clay, is the best; for early crops, mild manure, such as leaf mould, should be employed. Plant as early as the weather will permit, in well prepared soil, and cover about two or three inches deep. Sow three feet apart for early kinds. and four feet for late. For a continuous supply, sow from early in April until the last of June; then discontinue until the middle of August, when an early sort will sometimes produce a rood crop.

\section{Philipps' Extra Early Summit Pea.}

The Elarliest, Evenest Cropper, the Hardiest, Finest Flavored and Most Productive.

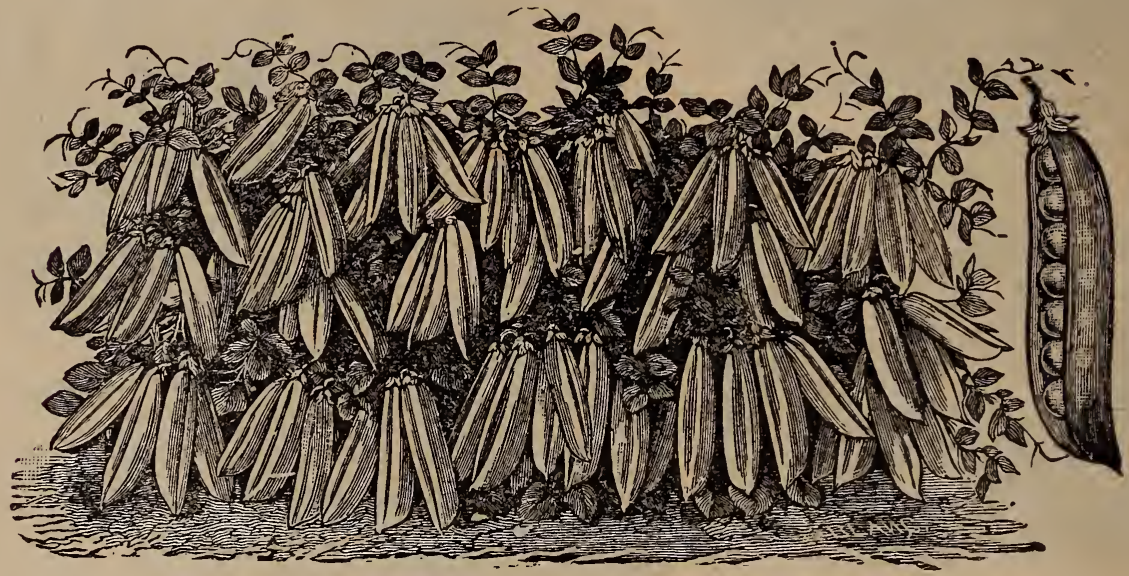

CONEIDENCE WELL PLACED.

Philipps' Extra Ealy Summit Pea. Most profitable Pea for Market Gardeners to grow. This Extra Early Summit Pea is a careful selection of our own and will be found ENTIRELY DISTINCT AND SUPERIOR to any other. In the neck-and-neck race for the production of first class Peas (each seedsman naturally eadeavoringto have the earliest), we claim that "The Summit," we introduced and for us specially grown, is the EARLIEST, BEST AND MOST PRODUCTIVE white round pea grown, NONE AS EARLY, maturing all the pods in about forty-five days : height about two feet, and ninety-five per cent. of the gathering in one picking. Also for a late fall crop it $1 \mathrm{~s}$ unsurpassed, growing with great rapidity. The very best for market garden use, and we confidently recommend it in every garden for the EARLIEST crop. $1 / 2$ pint $10 \mathrm{c} ;$ pint $15 \mathrm{c}$; quart $25 \mathrm{c}$; peck $\$ 1.50$; bushel $\$ 5.00$.

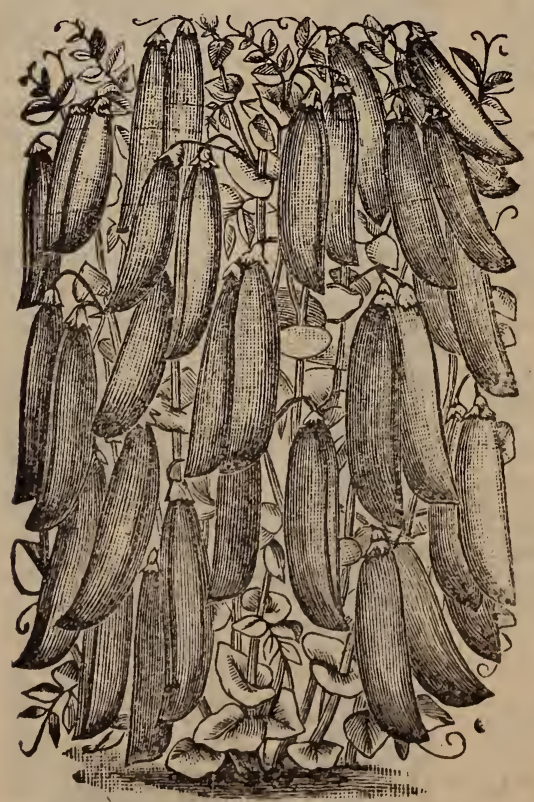

CARTER'S EXTRA EARLY PREMIUM GEM and productive. Height 15 inches. Highly recommended. Try it. $1 / 2$ pint $10 \mathrm{c} ;$ pint $15 \mathrm{c} ;$ quart
$2.00 ;$ bu. $\$ 7.00$ $30 \mathrm{c}$; peck $\$ 2.00$; bu. $\$ 7.00$ green color. A type of and improvement on the Little Gem.

Extra Early Alaska. This heautiful blue market Pea has become a standard variety, and the earliest of all blue Peas. The vines are dwarf, growing only about twenty inches high-very uniform, maturing the crop for one picking - of excellent quality, fine flavor, sweet, and retains its desirable color after cooking. Excellent for canning and for the market or private garden. Pkt. $5 c$; pint $15 \mathrm{c}$; quart $25 \mathrm{c}$; peck $\$ 1.50$; bu. $\$ 5.50$.

Landreths' Extra Early Pea. (None genuine unless in redsealed bags or in our packages). Pkt. $5 \mathrm{c} ; 1 / 2$ pint $10 \mathrm{c}$; pint $15 \mathrm{c}$. quart $25 \mathrm{c}$; peck $\$ 1.50$; bushe1 $\$ 5.50$.

Rural New Yorker. This well known standard variety of extre early Pea is still the favorite of many for market and private garden. Seed white, slightly dented, of vigorous habit. Pods of fine shape. contain from six to nine peas of fine qualityprolific, extra early, uniform in growth and ripening-height 24 inches. Pkt. $5 \mathrm{c}$; pint $15 \mathrm{c}$; quart $25 \mathrm{c}$; peck $\$ 1.50$; bu. $\$ 5.00$.

Nott's Excelsior. Extra early. A cross between American Wonder and Advancer; grows one foot high, very hardy and vigorous : can be planted with perfect safety in early Spring with any smooth varieties, and will mature almost as soon, while the quality is far superior; pods very large and well filled with tender and fine flavored peas. Early, hardy, productive, extra fine: ready for table in forty-five days. Earlier by several days than Little Geni-a fine bearer-earliest wrinkled Pea. Pkt. 5c ; pint $15 \mathrm{c}$; quart $30 \mathrm{c}$; feck $\$ 2.00$; bu. $\$ 7.50$.

Blisa' American Wonder. The earliest of the wrinkled peas, and best for family use. Very dwarf, nine inches high, and re. markably productive, well filled pods, flavor unsurpassed. We heartily recomnend this valuable pea. Ykt. $5 \mathrm{c}$; pint $15 \mathrm{c}$; quart $30 \mathrm{c}$; peck $\$ 2.110$; bu. $\$ 7.00$.

McLcan's Little Gem. Seed green, wrinkled. Height 15 inches. Second early. Very prolific and excellent flavor. Especially reconımended for family garden. Pkt. 5c; pint $15 c$; quart $25 c$ : reconimended for famil $\$ 1.75 ;$ bushel $\$ 6.75$.

Carter's Extra Carly Premium Gem. Podslong and of a dark 


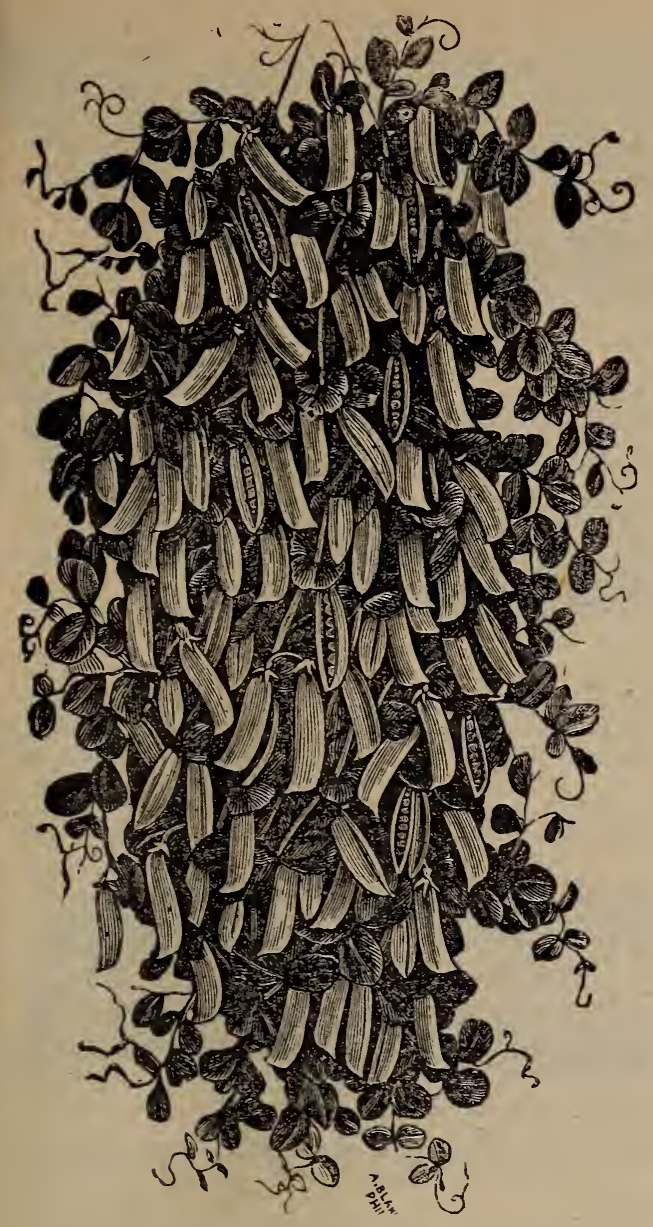

BLISS' EVERBEARING.

The Heroine. This is one of the mammoth-podded, English-bred varieties, of elegant habit of growth luxuriant foliage, pods remarkably handsome, slightiy curved, well filled with large, luscious peas of fine flavor, a gem of the flrst water. It is similar to Pride of the Market, but far superior to the variety in habit, as it is remarkably true and fixed in its habits of growth. This is one of the grandest Peas on the entire list, is now offered at a price that places it within the reach of all. It should be in every garden. Height two feet, seed green and very much wrinkled. Pkt. 5c; $1 / 2$ pint $10 \mathrm{c}$; pint $15 \mathrm{c}$; quart $25 \mathrm{c}$; peck $\$ 1.25$; bu. $\$ 4.50$.

Carter's Telephone. Season midway between First in Market and Marrowfat. Green, wrinkled, height $3 \frac{1}{2}$ feet-enormously productive-pods unusually large elegant shape and well filled with peas of large size and good quality. Average 18 pods to the stalk. Pkt. $5 \mathrm{c}$; $1 / 2$ pint $15 \mathrm{c}$; quart $25 \mathrm{c}$; peck $\$ 1.50$; bu. $\$ 5.50$.

Dwarf White Marrowfat. A sturdy variety, prolific and of good quality-vines thirty inches high, foliage strong and dark, maturing about seventy days after germination. Pkt. $5 \mathrm{c}$; pint $10 \mathrm{c}$; quart $15 \mathrm{c}$; peck $75 \mathrm{c} ;$ bu. $\$ 3.00$.

Black-Eyed Marrowfut. This is extensively grown as a garden and field Pea-very productive-height about $31 / 2$ feet, with large and well filled pods-a popular market variety. Pkt. $5 \mathrm{c}$; pint $10 \mathrm{c}$; quart $15 \mathrm{c}$; peck $25 \mathrm{c}$; bu. $\$ 3.00$.

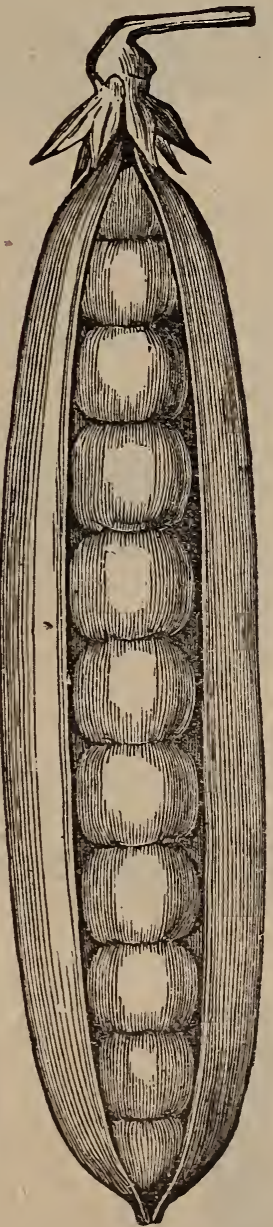

THE HEROINE.

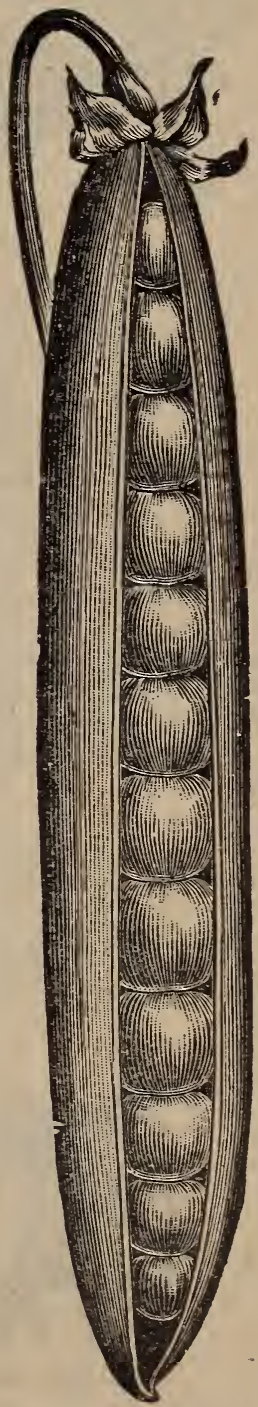

TELEPHÓNE.

White Marrowfat. Tall. A favorite variety for market, canning and field cultivation-very large, broad pods, well filled, height four feet. Pkt. $5 \mathrm{c}$; pin $\mathrm{t} 10 \mathrm{c}$; quart $15 \mathrm{c}$; peck $75 \mathrm{c}$; bu. $\$ 3.00$.

EDIBLE PODDED OR MELTING SUGAR SORTS.

Tall and Dwarf Sugar. Edible pods. About two feet in height, very sweet and tender. Only to be eaten with pods. Pkt. $5 \mathrm{c}$; $1 / 2$ pint $10 \mathrm{c}$; pint $15 \mathrm{c}$; quart $25 \mathrm{c}$; peck $\$ 1.75$.

Dwarf Grey Sugar. Edible pods. Grows about two feet high and is remarkable for its earliness as well as its character. The seeds are large, shrivelled and of dark brown color. The pods are broad, flat and crooked, and contain five or six peas. Pkt. $5 \mathrm{c}$; $1 / 2$ pint $10 \mathrm{c}$; pint $15 \mathrm{c}$; quart $25 \mathrm{c}$; peck $\$ 1.75$. 


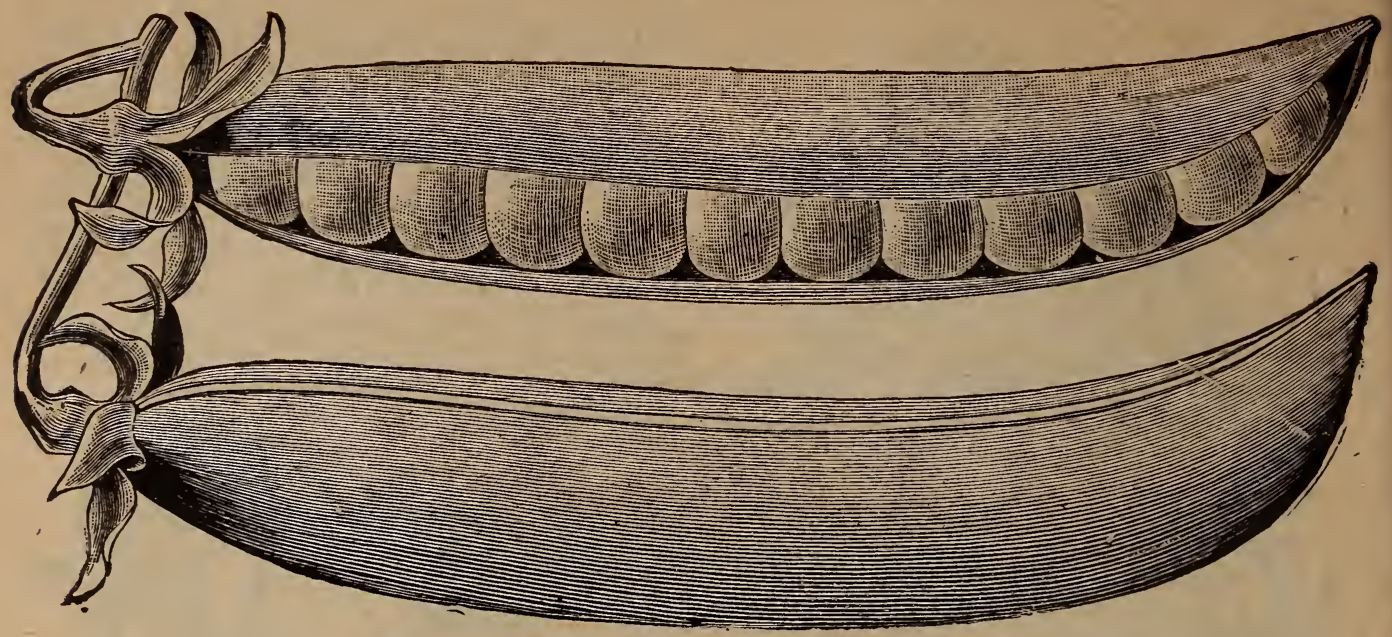

GRADUS.

Gradus. The most attractive novelty of recent years-large, hanc'some pods, resembling Telepone in size and shape, well filled with large peas, ripening with the earliest, is certain to be eagerly sought. Ripening very quickly, the pods must be picked as soon as fit for the table. Habit vigorous, very quick to germinate and push to maturity-follage large, pale green in color-pods long, straight, slightly rounded at the point, seed large, wrinkled, cream color, helght 3 feet. Pkt. 10c; pint $25 \mathrm{c}$; quart $40 \mathrm{c}$; peck $\$ 3.00$; bushel $\$ 12.00$.

Champion of England. A variety possessing merit of high order, wrinkled and very sugary-requires sticking. Ripens for table in seventy days from germination. Pkt. 5c; 1/2 pint 10c; pirt :15c; quart 25c; peck $\$ 1.25$; bushel $\$ 4.25$.

Pride of the Market. Is a strong growing Pea two feet high, wonderfully productive. The pods are of large size and hand. some appearance, and the Peas are of splen. did quality. Similar

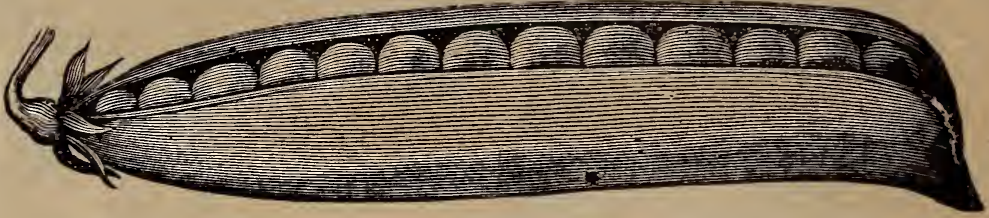

PRIDE OF THE MARKET.

to Stratagem and Telephore. Pkt. $5 c$; $1 / 2$ pint $10 \mathrm{c}$; pint $15 \mathrm{c}$; quart $25 \mathrm{c}$; peck $\$ 1.50$; bushel $\$ 5.50$.

\section{PEPPERS.}

CULTURE - Sow each kind in drills on a warm border, late in Spring or commencement of Summer, snd thin to stand sixteen or eighteen inches a part-or they may be sown early in the season in a hotbed or flowerpot and transplanted.

Mammoth Ruby King. A very mild flavored variely which grows to a large size, often 5 or 6 inches long and 3 or 4 inches thick, of a bright ruby red color when ripe-fine for Mangoes. Plants are stocky and very prolific Pkt. $5 \mathrm{c} ; 1 / 2 \mathrm{oz} .15 \mathrm{c} ; \mathrm{oz} .25 \mathrm{c} ; 4 \mathrm{oz} .75 \mathrm{c}$.

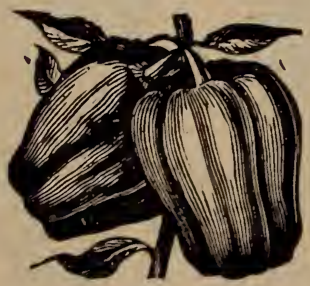

GOLDEN BELL.

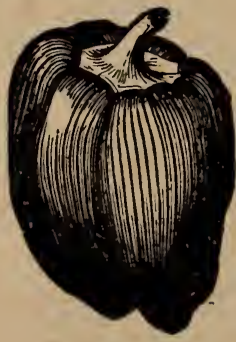

RUBY KING.

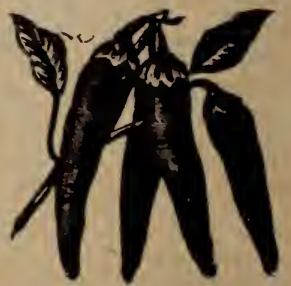

CAYENNE (LONG.)

Golden Bell or Golden Dawn. Similar to Sweet Spanish, except the color, which is golden: Very early, mild flavor. Pkt. $5 c ; 1 / 20 z .15 c ; 0 z .25 \mathrm{c} ; 4 \mathrm{oz} .75 \mathrm{c}$.

Red Cherry. Ornamental pickles, very small, very hot. Pkt. 5c; 1/2 oz. 15c; oz. 25c; 4 oz. 75c.

Large Bell or Bull Nose. Earlier than other large size Peppers, thick meated, very mild flavor, excellent for stuffed pickles or Mangoes. Pkt. $5 \mathrm{c} ; 1 / 20 z .15 \mathrm{c} ; 0 z .20 \mathrm{c} ; 4 \mathrm{oz} .75 \mathrm{c}$.

Sweet Mountain or Mammoth, Similar to the Bull Nose, but larger and milder in flavor. For stufed pickles, "Mangoes," 6 to 7 inches. Pkt. 6c; $1 / 20 z .15 \mathrm{c} ; 0 z .20 \mathrm{c} ; 4 \mathrm{oz}$. 75c.

Long Red Oayenne. Fruit long, slim and bright red in color. Pkt. $5 \mathrm{c} ; 3 / 2 \mathrm{oz} .15 \mathrm{c} ; \mathrm{oz} .85 \mathrm{c} ; 4 \mathrm{oz} .75 \mathrm{c}$.

Very Small Cayenne. Bright red color, very hot. Pkt. 5c; $1 / 2$ oz. 15c; oz. 25c; 4 oz. $75 \mathrm{c}$.

Pepper Plants. Ready May 1st. By mail, doz. 25c; 100, $\$ 1.00$. By expres, 100, 75c. 


\title{
PRICE LIST OF
}

\section{Choice Northern Grown Seed Potatoes.}

\author{
CHANGE YOUR SEED.
}

\author{
Growing Potatoes for Seed has been a Specialty with us for Years.
}

In drills three feet a part, ten to twelve bushels to the acre. One peck will plant about 125 hills.

The Potato like all robust growing vegetables, can be grown with varying success in soils of all kinds, and in all conditions of fertility, but the soil best suited to it is a sandy loam. In all heavy soils it is more subject to disease, and the flavor also is much inferior. In breaking up good pasture land the decaying sod answers sufficiently well for the first year in lieu of manure. Manure is applied either in rows or hills, or broadcast over the hills and plowed in-the latter in most cases being preferable. If the soil is good but little manure is required. In highly enriched soil the plants are more liable to disease than when grown in soil that is naturally good. The best fertilizers are those of a dry or absorbent nature, as plaster lime, superphcsphate of lime and bone dust. For wet soils these are particularly beneficial, as they not only promote growth, but prevent disease. Plant as early in Spring as the ground can be had in fair working order, in hills or ridges three feet a part, covering in light, warm soils about four inches deep, but in cold, wet situations two and one-half or three inches will be sufficient.

By using our Northern-grown seed you are assured of EARLY MATURITY, INCREASED YIELD AND VIGOROUS CROWTH. Our stock has been grown from selected seed and expressly for seed purposes. We book orders at any time, and fill them in rotation just as soon, in our judgment, as the weather will permit. However, we cannot become responsible for changes in the weather by which they may become damaged en route. We will ship at any time when requested to do so, regardless of the weather, but customers must take the risk. PRICES SUBJECT TO VARIATIONS OF THE MARKET.

SPECIAL PRICES given on most kinds for large quantities, on application. When customers request it we will pack a barrel with two or three kinds without extra charge.

Our Potatoes are all specially raiseỏ for seed purposes, and are "Northern grown" by us and for us in Michigan and around Toledo. We deliver all Potatoes into the hands of transportation companies, safely packed; after that our responsibility ceases. Purchasers must take all risks from freezing or heating. In comparing our prices on Potatoes, remember we make no charges for barrels or cartage, but deliver F. O. B. at Toledo at prices quoted. Our barrels contain $165 \mathrm{lbs}$. net.

PRICES GIVEN ARE SUBJECT TO VARIATIONS WITHOUT NOTICE.

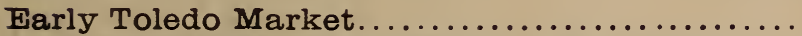

Early Wonderful Freeman (from original stock) ...

Farly Beauty of Hebron (a beauty)..............

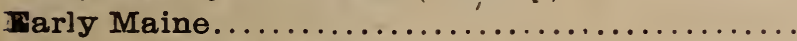

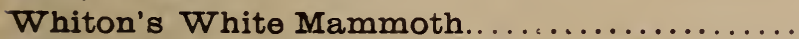

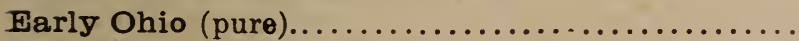

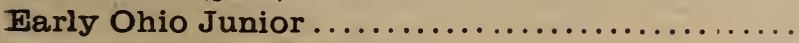

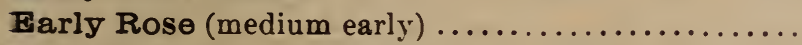

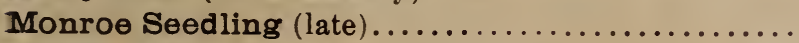

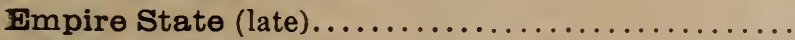

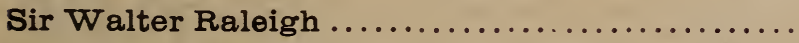

Rural New Yorker No. 2 (a very heavy cropper) ...

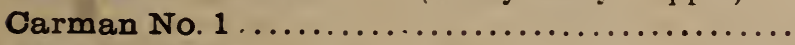

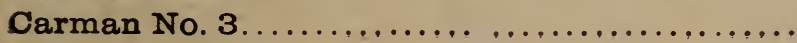

\begin{tabular}{|c|c|c|c|}
\hline 1/2 Peck. & Peck. & Bushel. & Bbl. \\
\hline$\$ 020$ & $\$ 040$ & $\$ 150$ & $\$ 400$ \\
\hline 20 & 40 & 125 & 350 \\
\hline 20 & 40 & 125 & 350 \\
\hline 20 & 40 & 125 & 350 \\
\hline 25 & 50 & 150 & 400 \\
\hline 20 & 40 & 150 & 400 \\
\hline 20 & 40 & 150 & 400 \\
\hline 20 & 40 & 125 & 350 \\
\hline 20 & 40 & 125 & 350 \\
\hline 20 & 40 & 125 & 350 \\
\hline 20 & 40 & 125 & 350 \\
\hline 20 & 40 & 125 & -350 \\
\hline 20 & 40 & 125 & 350 \\
\hline 20 & 40 & 125 & 350 \\
\hline
\end{tabular}

Single pound $10 \mathrm{c}$; ; by mail $20 \mathrm{c}$, or $4 \mathrm{lbs}$. by mail $60 \mathrm{c}$, of any of the above varieties.

These prices are binding only so long as our stock of any variety remains unsold. Potatoes growa in our section and Northern Michigan are far better for planting in the Middle, Southern and even Eastern States than the Western grown, In earliness, yield and quality, and should be preferred by all who grow for market or private garden. 


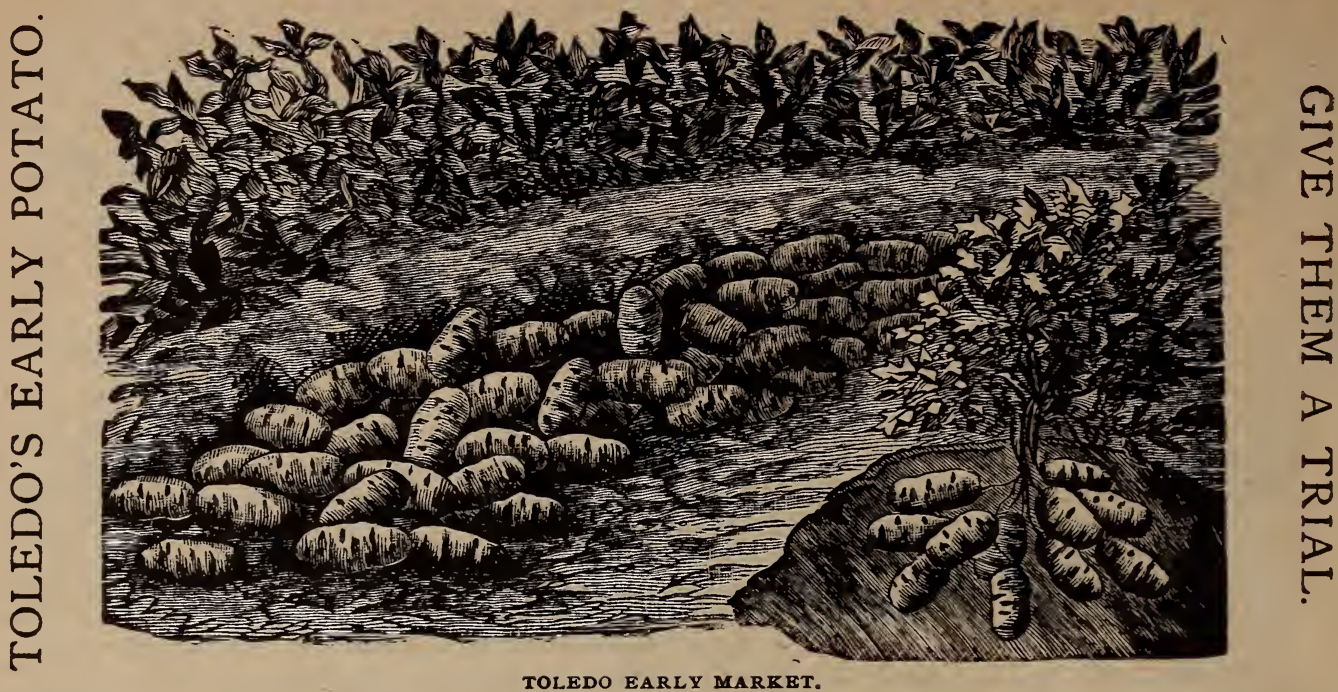

Toledo Early Market. Six Weeks' Potato. Especially recommended for early marketing. MARKKT GARDRNERS should try this Potato because it is extra early and of a fine quality, cooking well as soon as it attains marketable size. Tubers similar to Early Rose, large, light pink or flesh color. An immense yielder, flesh very white; cooks dry and mealy. Good keeper, being excellent till planting time. (See price list.)

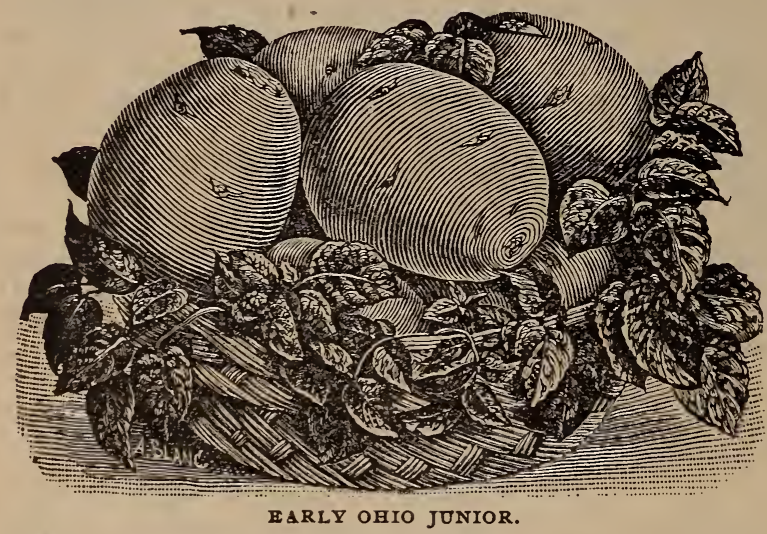

Ohio Junior. (Extra Early.) This potato originated in a chance seeding; it is without doubt in some way related to that good old sort, the "Early Ohio," as it is almost identical with that variety in the form and marking of the tubers, habit and growth, etc. The tubers are ovaloblong, with full eyes that are almost even with the surface. It is an excellent keeper, very productive, of fine quality, and has proved to be a most valuable addition to our list of Extra Early varieties. (See price list.)

Early Beauty of Hebron. One of the best early sort productive and of excellent flavor, good keeper, pure white skin and flesh; a beauty. (See price list.)

Early Maine. This potato originated from a seed ball of the Farly Rose, resembles its parent in color, but nicer shaped and smoother, and far superior in productive. ness and quality. Our stock is very choice. (See price list.)

Early Rose. Every cultivator of the Potato, both far and near is familiar with the Farly Rose. It was the pioneer of all the improved varieties, its highly extolled character has not depreciated. (See price list.)

Improved Extra Early Ohio. The earliest market potato, is well known and popular. The tubers are of good size, always cook dry and mealy, and can be eaten long before the tops die down. (See price list.)

The Great Early Freeman Potato. This extra early variety was introduced under the broad claims of being the greatest potato introduced since the Early Rose. It has made a wonderful record, giving enormous yields in all sections where grown. It has a handsome shape and heautiful russet skin, and is fully equal to the old Snowflake in eating qualities. It will pay every tiller of the soil to plant the Freeman. (See price list.)

Empire State. A main crop of oblong variety, wonderfully productive, does well on almost any soil. The skin is white and smooth, flesh pure white, of fine flavor. (See price list.)

Monroe Seedling. A very productive, vigorous grower, its large, long, smooth white tubers render it so valuable that it has become very popular. (See price list).

The New Potato Carman, No 1, has the peculiarity of being a seedling from seedlings raised through several generations, is intermediate between early and late in ripening. It has but few eyes, and these shallow. The flesh is white as flour, and the quality perfect, being not only dry but of excellent flavor, is a hearty. vigorous grower, the vines being remarkably stout and stalky. A great cropper, the tubers are extra large, with hardly one among them below market size. We hearlily recommend it to all our customers, it cannot fail to give satisfaction. RIPENS IN TIME TO SOW GROUND TO WHEAT AND RYE. OUr stock is grown from specially selected seed of original stock, and is free from scab or rot.

Carman No. 3. This splendid Potato is without any approach to an exception. the greatest yielder ever introduced. It may be fairly claimed that it does not yield any small tubers at all. It bears its tubers very close to the plant, a single turn of the fork turning out every Potato. It is of the largest size and of the shapeliest form, almost similar to Carman No. 1. It is a perfect keeper, that is, it will not sprout up to planting tlme, unless kept in a warm place. Both skin and flesh are of extreme whiteness. Eyes few and shallow. (See price list.) 


\section{A Seedling of the Peach Blow.-Try It.}

\section{A Larger Yielder Than the Carman. Buy It.}

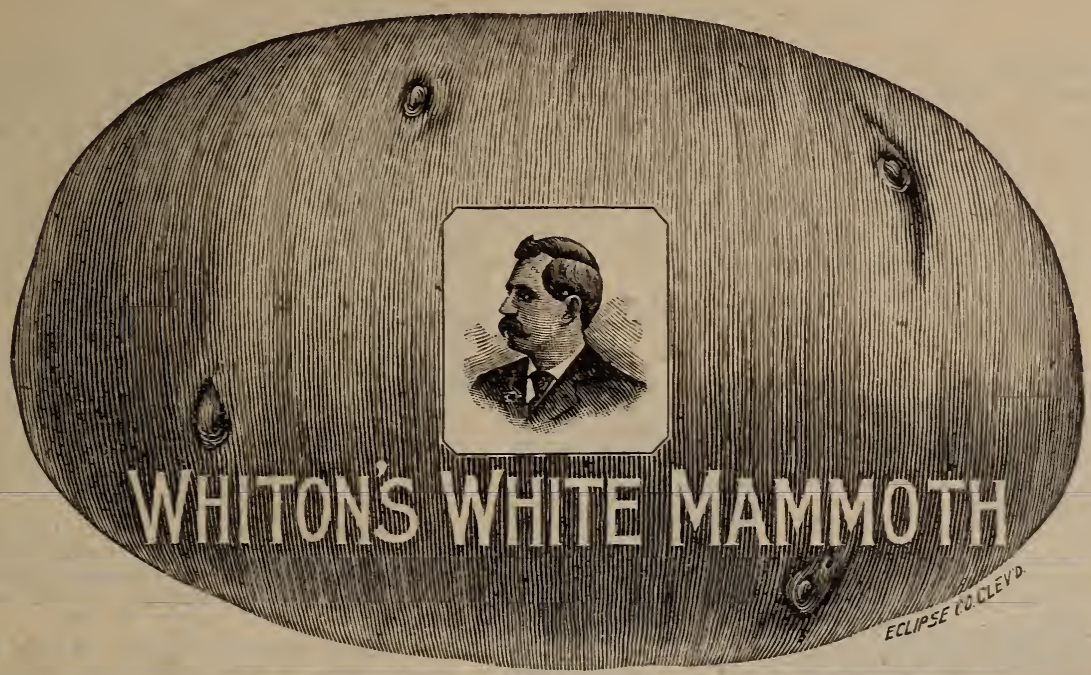

Whiton's White Mammoth. Last year we purchased the entire crop of this great New Potato of $\mathbf{M r}$. Whiton, and now offer the original stock direct from our grower at the extremely low price as named:0s page 42 .

This Potato"was grown from seed taken out of a ball grown on a Peachblow vine.

This Potato has improved each year from seed, and we can refer to many leading agriculturists who hare tried it and pronounce it a grand Potato in every way.

Solid built white tubers very thickly netted, a quick, strong grower, and keeps free from blight and buge. Cooks dry and has a fine flavor. Is an immense yielder, grows compact in hill, which makes harvesting easy. We recommend every one of our customers to try this Potato, and know they will be pleased with it. Cam be grown on any soil. (See price list.)

Rural Now Ynrker, No 2. A splendid intermediate and main crop Potato, originated on the experiment grounds of the Rural New Yorker. It is most distinct in appearance, and could readily be distinguished among a hundred other varieties. Very large and unusually smooth, with few and shallow eyes, in form oblong, inclined to round, flesh white and of superior quality. The vines are very strong, and yield handsome tubers of great uniformity ; wonderful cropper. (See price list.)

sir Walter Raleigh. Introduced by Mr. Carman. Resembles Rural New Yorker, No. 2, of which it is a seedling and is one of the grandest general crop Potatoes now offered. (See price list.)

\section{Seed Sweet Potatoes.}

Grown especially for Seed purposes in this State and New Jersey, of the following varieties : Yellow Nansemond, Yellow Jersey. Per 1b. 10c, bushel $\$ 2.00$. barrel $\$ 4.00$. Write for special prices for large quantities.

Sweet Potato Plants. Ready May 1st. We make a specialty of supplying first-class Sweel Potato Plants, and we take great pains to send out only such as are strong, vigorous, well rooted and hardy. $U$ rite if yon want a large lot, as prices may be lower. Price, by mail, $100,60 \mathrm{c}$; by express, per $100,30 \mathrm{c} ; 1,000, \$ 2.50$.

\section{Pumpkin for Table and Field.}

CULTURE.-May be planted after first of May, among the Indian corn, or in the field or garden, in hills of eight or ten feet a part each way, four seeds in a hill.

Large Sweet Cheese. Excellent for cooking purposes, orange colored, flesh yellow and sweet, very produc tive, and excellent for pies, also stock. Pkt. 5c, oz. 10c, 1/4 1b. 20c, 1b. 50c.

Large Tours or Mammoth. Grows to an immense size, often weighing over 200 pounds, very productive, for cattle and table, flesh bright yellow. Pkt. 5c, oz. 10c, $1 / 41 \mathrm{~b} .20 \mathrm{c}, 1 \mathrm{~b} .50 \mathrm{c}$.

Cushaw. Resembling the White Crookneck-Squash, flesh salmon yellow. Pkt. 5c, oz. 10c, 1/21b. 25c, 1b. 70c.

Connecticut Field. The common large yellow field Pumpkin, good for stock. Pint $15 \mathrm{c}$, quart $20 \mathrm{c}$, bushel $\$ 3.50$.

Sugar. This great pie Pumpkin is used exclusively in making the celebrated Yankee Pumpkin pies. Of fine, sugary flavor, fine grained. Pkt. $5 \mathrm{c}, 0 \mathrm{z} .10 \mathrm{c}, 1 / 4 \mathrm{lb} .25 \mathrm{c}, 1 \mathrm{~b} .60 \mathrm{c}$. 


\title{
R A D ISH.
}

\section{American and French Grown Radishes for all the Year Round.}

\author{
One Ounce will Sow 100 Feet of Drills; 8 to 10 lbs, for an Acre.
}

CULTURE.-All the varieties thrive best in light, sandy loam. For easly use sow in hotbed, giving plenty of ventilation, or outside in drills as soon as the soil can be gotten in order, covering the seed about half an inch deep. Sow every two weeks from March to September, for a succession. They must grow rapidly to be crisp and tender.

\section{All Seed Saved from Selected and Transplanted Roots.}

Special prices for those buying in larger lots. Five pounds of any variety at 10c. less per pound.

EXTRA EARLY AND FORCING VARIETIES.

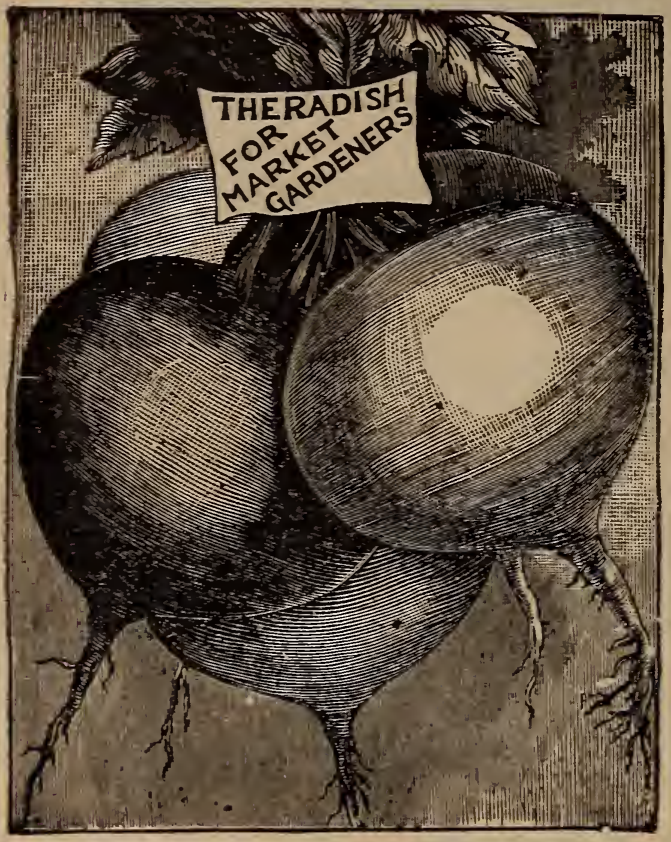

EXTRA EARLY DEEP SCARLET PRUSSIAK GLOBE RADISH.

Extra Early Scarlet Prussian or Vicks' Globe. Eighteen days to maturity. A small leaved variety well adapted for forcing under glass, root round and carmine colored, early, very attractive and desirable, fine for forcing. A new color and very choice. Every gardener should have it. Pkt. 5e; oz. $10 \mathrm{c} ; 1 / 4 \mathrm{lb} .20 \mathrm{c}$; $1 \mathrm{~b}$. $70 \mathrm{c}$.

Early Scarlet Forcing Turnip. Quickest in maturity of any of the Red Turnip Radishes, crisp root and small top, an excellent forcing variety, as well as in private garden. Don't fail to try it. Pkt. 5c; 0z. 10c 4 oz. 20c; 1b. 20c.

Extra Early Scarlet Turnip. White Tipped. A fancy French variety, scarlet bulb with white bottom. Very showy and delicate. Choice variety for forcing and open ground. Pkt. 5c; oz. 10c; 4 oz. 20c; 1b. $70 \mathrm{c}$.

Earliest White T urnip. A remarkably early sort for forcing, very few and small leaves, crisp and delicate bulbs (new). Pkt. $5 \mathrm{c}$; oz. $10 \mathrm{c} ; 4$ oz. $20 \mathrm{c}$; $1 \mathrm{~b} .60 \mathrm{c}$.

Olive-Shaped Scarjet White-Tipped French Breakfast Radish. A variety of quick growth. Very mild and tender, one of the best for forcing, oval form, scarlet, tipped with white. Pkt. 5c; 0z. 10c; Y 1 1b. 20c; Ib. 60 c.

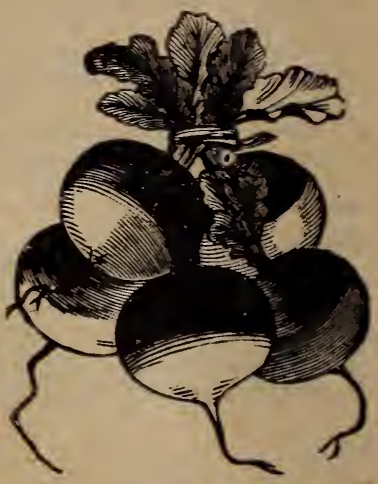

EARLY SCARLET WEITE. TIPPED RADISH.

Half Long Dpep Scarlet. Matures in 21 days, is red, and grows from three to four Inches. Pkt $5 c ; 0 z .10 c$; $1 / 4$ lb. 20 e ; 1b. 70c.

Wood's Early Frame. Shorter and thicker than the Long Scarlet Short Top. Best long Radish for forcing, also good for out door crop, either Spring or Fall, mild brittle, of fine flavor. Pkt.5c; oz. 10c; 1/4 1b. 20c; ib. 60 c.

Market Gardeners' Early Long Scarlet Short Top. Brightest scarlet. The well known Long Red market variety. Pkt. $5 \mathrm{c}$; 0z. 10c; $/ 4$ lb. 20c; 1b. 30c.

"Cineinnati Market" Radish. (The Best Long Red Radish in Cultization). This wonderful new Radish has won special favor in all sections of the country, and sells more readlly than any other variety that is put in competition with it on the market. The tops are very small, and the radishes may stand mueh closer in the rows than Wood's Early Frame and Long Scarlet without danger of running up to seed. They grow straight and smooth and from six to seven inches in length, the flesh is exceedingly tender, crisp and delicious, never becoming hollow and pithy, the skin is very thin and has an attractive, glossy, scarlet appearance. This is undoubtedly the finest Long Red Radish for every purpose, being equally desirable for the market or home garden. Pkt. $5 \mathrm{c} ; 0 \mathrm{z} .10 \mathrm{c} ; 1 / 4 \mathrm{~b}$. $20 \mathrm{c} ; 1 \mathrm{~b} .65 \mathrm{c}$.

Early White Giant Stuttgart Summer. (Round). A large grower, top-shaped and long keeper, all white, smooth, brittle, never pithy, second early. Pkt. be; oz. 10c; $1 / 41 \mathrm{lb}$. 20e; 1b. 70c.

Livingston s Poarl Forcing. A cross between Wood's Farly Frame and White Strasburg, making the best half long White Radish for Market Gardeners. Try it. Pkt. $5 \mathrm{c} ; 0 z .10 \mathrm{c} ; \mathrm{K} / \mathrm{lb} .25 \mathrm{c}$; Ib. $75 \mathrm{c}$.

White Lady Finger. Twenty-four days to maturity, quick growing, long, slim white, a great favorite, the only good long early white radish, very crisp and nutty. Pkt. $5 \mathrm{c} ; 0 z .10 \mathrm{c} ; 1 / 4 \mathrm{lb}$. $25 \mathrm{c}$; ib. $76 \mathrm{c}$. 


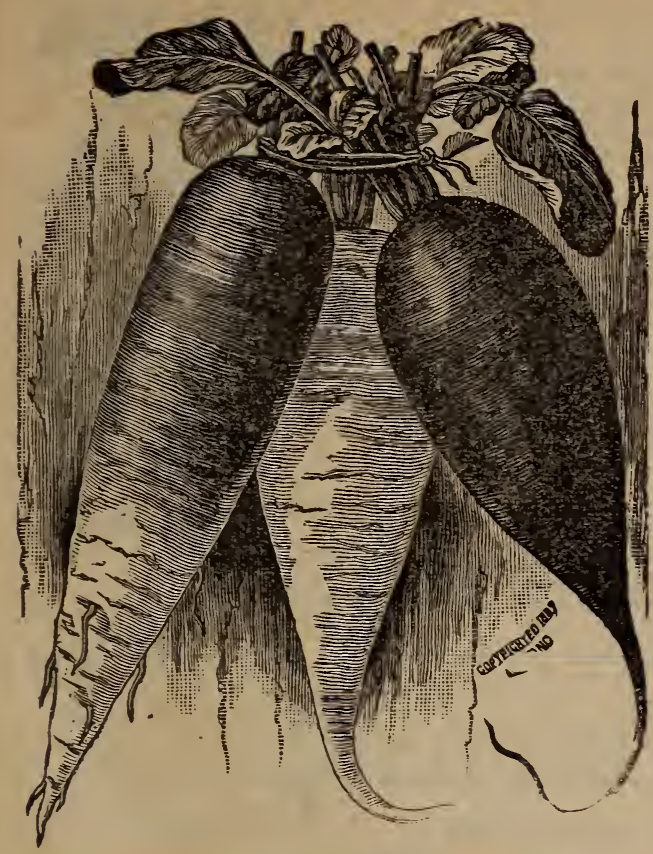

THE CHARTIER, WHITE STRASEURG AND HALF LONG DEEP SCARLET.

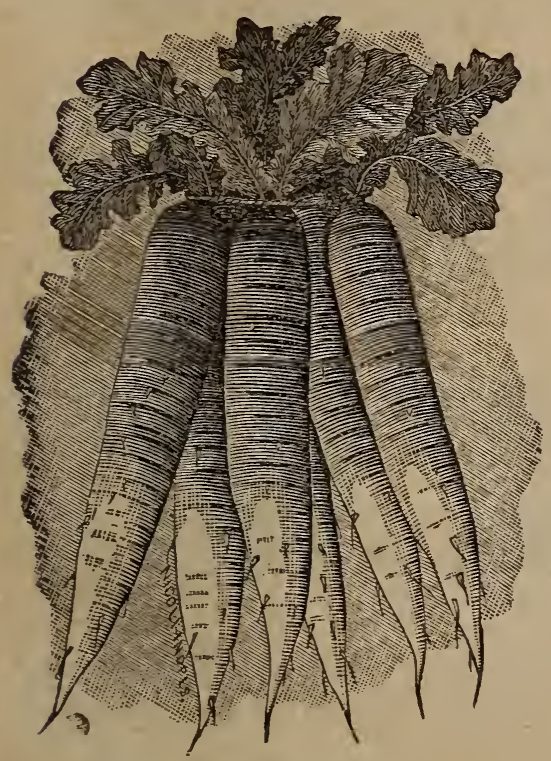

MARKET GARDENERS' EARLY LONG SCARLET.
Golden Yellow Summer. Expressly growi for us. The best Summer Radish. Shape globular, color amber, flavor mild, keeping long in eating condition. Withstanding heat well. Pkt. $5 \mathrm{c}$; oz. $10 \mathrm{c} ; \mathrm{r} / 4 \mathrm{lb} .20 \mathrm{c} ; 1 \mathrm{~b} .60 \mathrm{c}$.

Long White Vienna. Beautiful in shape, skip and flesh pure snow wbite, crisp and of rapid growth. Pkt. 5c; oz. 10c; 1/4 1b. 20c; 1b. 70c.

Early Golden Yellow Oval. A comparatively new sort, very popular in the New York market. The roots are oval, very smooth and handsome, bright, light yellow color, and of fine quality. It matures very quickly and has a small top and neck. Our stock is grown from selected roots and is very fine. Pkt. $5 \mathrm{c} ; 0 z .10 \mathrm{c} ; \mathrm{t} / \mathrm{tb}, 20 \mathrm{c}$; lb. 70 c.

White Strasburg, It is of a tapering shape, skin and flesh both white. It is an excellent Summer variety, being tender, crisp and of fine flavor, and a quick grower. Pkt. $5 \mathrm{c} ; 0 \mathrm{z} .10 \mathrm{c} ; \mathrm{t} / \mathrm{lb} \mathrm{lb} 2 \mathrm{c}$; 1b. $65 \mathrm{c}$.

Improved Chartier. (Scarlet, white tip). A distinct, exceedingly handsome and attractive sort. Color of the top is scarlet rose, shading into pure waxy-white at the tip. Attains a very large size before it becomes unfit for the table, undoubtedly the best All Seasons Radish for the open ground. Ready for use or market nearly as early as Long Scarlef Short Top, and keeps crisp and tender for two months. Planted late it makes a good winter keeper. Pkt. $5 \mathrm{c} ;$ oz. $10 \mathrm{c} ; 1 / 4 \mathrm{lb}$. $20 \mathrm{c} ; 1 \mathrm{~b} .70 \mathrm{c}$.

Celestial. A comparatively new variety, which is popular wherever known. The root is long, cylindrical, with beautiful white skin and flesh, so white as to attract attention even when among the other white varieties. The flesh is tender and of good quality. Pkt. $5 \mathrm{c}$; oz. $10 \mathrm{c}$; $1 / 4$ lb. $25 \mathrm{c}$; 1b. 75 c.

Long White Spanish. Fall or Winter. A long Winter sort, very solid and crisp long keeping. Pkt. 5c oz. $10 \mathrm{c} ; \mathrm{r} / 4$ 1b. $20 \mathrm{c}$; 1b. $60 \mathrm{c}$

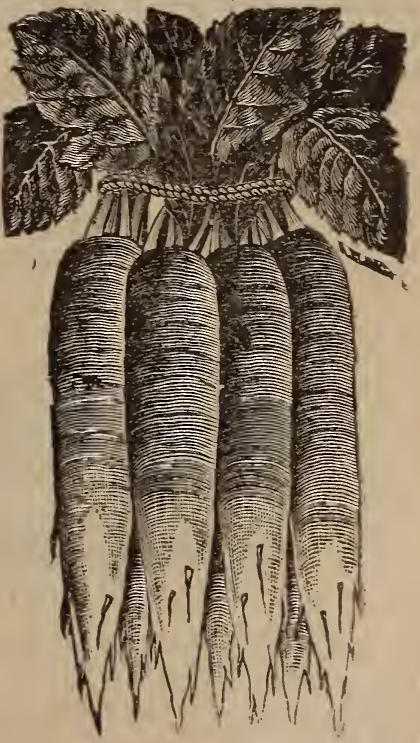

IMPROVED CHARTIER

Long Blaok Spanish. Winter. Grows six to eight inches long and about one and one-half inches through the top, skin black, flesh white and of firm texture. Pkt. $5 \mathrm{c} ; 0 \mathrm{z} .10 \mathrm{c} ; 1 / 1 \mathrm{lb} .20 \mathrm{c} ; 1 \mathrm{~b} .60 \mathrm{c}$.

Round Black Spanish. Winter. Like the above, except in shape. Pkt. $5 \mathrm{c} ; 0 \mathrm{z} .10 \mathrm{c} ; 1 / 4 \mathrm{lb} .20 \mathrm{c} ; 1 \mathrm{~b} .60 \mathrm{c}$.

Russian or California Mammoth White. Grown extensively by Chinese in California, 8 to 10 inches long. 2 to 3 inches in diameter, white, solid, good flavor. Pkt. $5 \mathrm{c} ; 0 z .10 \mathrm{c} ; 1 / 1 \mathrm{~b} .20 \mathrm{c} ; 1 \mathrm{~b} .70 \mathrm{c}$. 


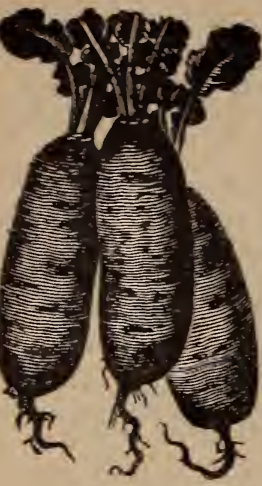

Rose or Scarlet China Winter. A fine Winter sort, root a half long stump of from three to four inches, scarlet and pink in color, tipped with white. Quite saleable in market during Fall and Winter. Keeps perfectly. Paper $5 c$; oz. $10 c$; $1 / 41 b .20 c$; lb. $70 c$.

Radishes are one of the most important vegetable crops for Market Gardeners and private garden. It depends a good deal upon the Seeds and soil and how to grow them. As to the first part we positively assure our friends that the Seed we offer is grown for us by the largest and the most reliable and best growers in France and this country, and we know and guarantee that our seed is equal to any offered by any first-class reliable seedsmen.

BLACK SPANISH.

\section{HORSE RADISH SETS.}

CULTURE.-Plant at any time during Spring, in rows about two feet apart and about eighteen inches apart in the rows. By mail, per doz., 25c. By express, per 100,75 ; per $1,000, \$ 6.00$.

\section{RHUBARB-PIE-PLANT.}

One ounce will produce about 1,000 Plants,

COLTURE.-SOw in April in drills one inch deep and one foot apart. When the plants are three or four inches high thin out to ten inches a part, and cultivate well during the season. In Fall or following Spring transplant into hills about three feet a part each way. The soil must be very deep and heavily manured. Give a top dressing of manure every Fall.

Mammoth Victoria, An excellent cooking variety. Pkt. $5 \mathrm{c} ; 0 \mathrm{z} .15 \mathrm{c} ; \mathrm{r} / \mathrm{lb}$. $40 \mathrm{c} ; 1 \mathrm{~b} . \$ 1.25$.

RHUBARB ROOTS.-Each, $20 \mathrm{c}$; doz. $\$ 1.50 ; 100, \$ 6.00$. By mail, postpaid, 30c. each, or $\$ 2.50$ per dozen.

Special prices as to sizes, quality and quantities on application.

\section{SALSIFY-Vegetable Oysters.}

When properly cooked it is a good substitute for Oysters in taste and flavor, and is very nutritious.

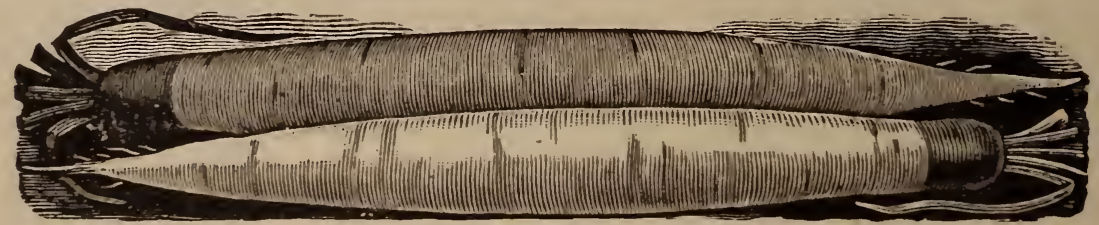

SANDWICH ISLAND MAMMOTH SALSIFY.

CULTORE.-Sow early in Spring in drills fifteen inches apart and one to two inches deep; thin to six inches apart. Soll should be deep and very mellow, in order that the long rnot may grow straight down. Store same as carrots for Winter use, or they can be left in the ground until Spring. One ounce of seed will sow fifty feet of drill.

Mammoth Sandwich Island. This variety is of enormous size, twice the size of the ordinary French, pure white, very tender and delicious. Invaluable for the market gardener and private garden. Pkt, $5 c$; ow. $10 \mathrm{c} ; 4$ oz. $35 \mathrm{c} ; 1 \mathrm{~b} . \$ 1.25$.

\section{SPINACH.}

Ten to Twelve Pounds are required for an Acre.

\section{Special Price in 5 and 10 Pound Lots}

COL,TURE.-For Spring use sow early in drills one foot apart, and every two wees for succession. As It grows thin out for use, keeplng it clear of weeds. For Fall use sow in August, for $F$ inter use in September, In well manured ground, mulch with straw on the approach of severe cold weather. 
SPINACH-CONTINUED.

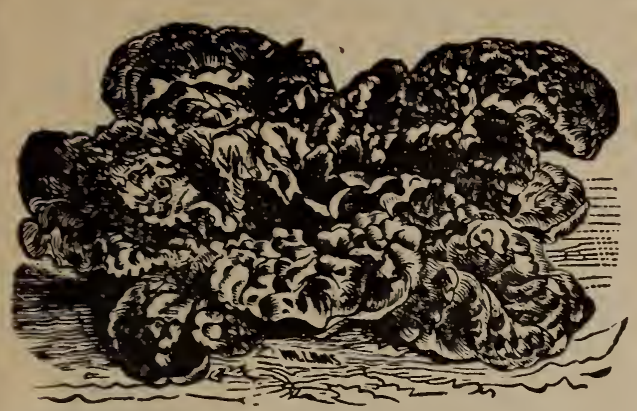

EXTRA LARGE THICK ROUND-LEAVED SPINACH.

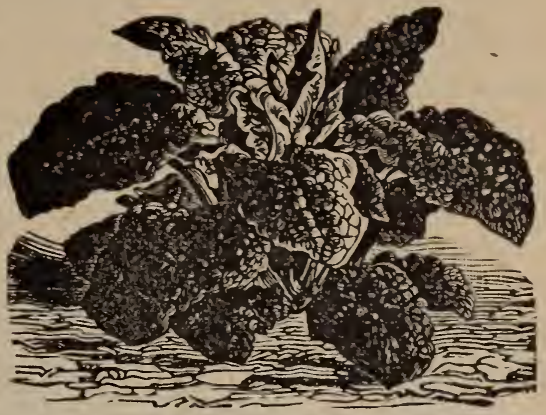

NEW LONG-STANDING SPINACH. 교요

Extra Large Thick Roand-Leaved. The Market Gardeners' favorite for Spring or Fall sowing. Very hardy and large cropper. Pkt. 5c; 2 oz. 10c; 4 oz. 15c; 1b. 25c.

New Long-Standing. Will stand an unusually long time before running to seed-in other respects it resembles the round-leaved closely. Pkt. $5 \mathrm{c} ; 2$ oz $10 \mathrm{c} ; 4 \mathrm{oz} .15 \mathrm{c} ; 1 \mathrm{~b} .25 \mathrm{c}$.

Victorim. (New). A favorite with Market Gardeners. Broad dark green leaves, heavy foliage, tender and keeps in good condition the longest of all Spinach. Pkt. $5 \mathrm{c} ; 2 \mathrm{oz} .10 \mathrm{c} ; 4 \mathrm{oz} .15 \mathrm{c} ; 1 \mathrm{~b} .30 \mathrm{c}$.

Curled-Leaved Savoy. (Norfolk Bloomsdale). The earliest variety, upright growth, fine, large, tender. savoy leaves. Quick growth. Pkt. 5c;2 oz. 10c; 4 oz. 15c; 1b. 25c.

Bloomsdale Savoy-Leaved. In 5 and $10 \mathrm{lb}$, sacks only, 25c. per $1 \mathrm{~b}$.

\title{
SQUASH.-Selected Seed.
}

\author{
SPECIAL PRICE TO LARGE BUYERS.
}

COLTURE.-Plant after all danger, from frost is past, and get in the Winter kinds as soon as possible, in order that they may mature. Plant in hills five feet apart for the bush varieties, and six or eight feet for the running varieties, putting six or eight seeds in the hill, finally leaving but three. One ounce of bush varieties for forty hills, or of large seeded running kinds, fifteen hills, three to four pounds for an acre.

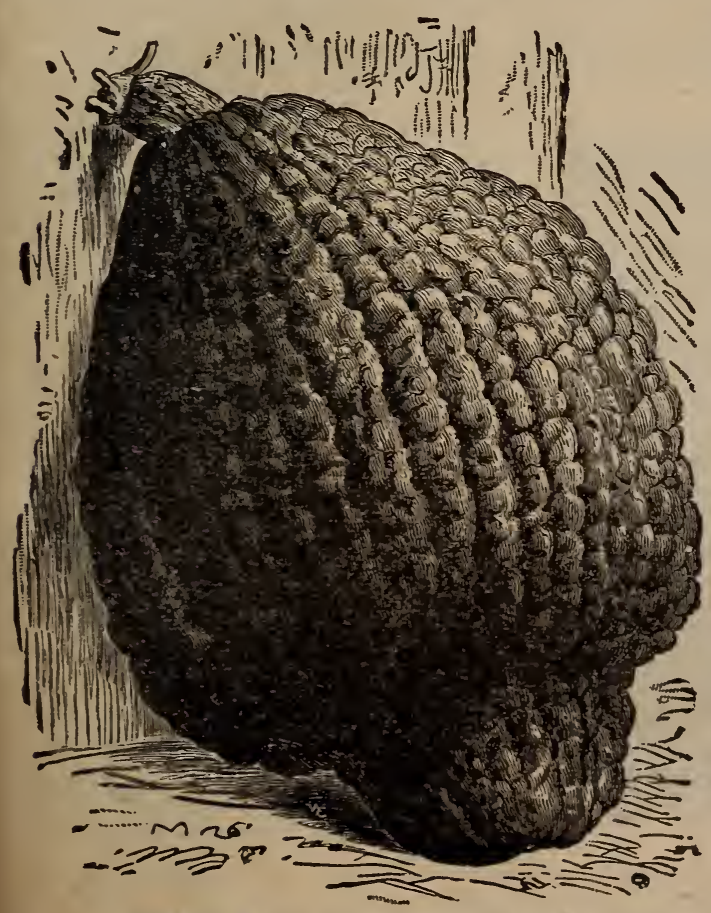

TOLEDO WARTED HUBBARD SQUASH
True Hubbard. Gererally considered the leading Squash for Fa!l and Winter use-good in any cli nate, hard skinned, splex did keeper-flesh dark yellow, fine grained, very dry and rich; very prolific We offer a very carefully grown stock. Pkt. $5 c$; oz. 15 c ; 4 oz. 25 c; 1b. 85 c.

Toledo Warted Hubbard Squash. For years it has been our aim to get an improved strain of Hubbard Squash. We finally succeeded, and now offer to our friends the Toledo Warted Squash (similar to the so-called Chicago), which we claim is the best strain in the $\mathrm{m}$ rket. A Hubbard Squash, large, blackish-green, hard as wood, with warty knots all over it, sati,fies even the inexperienced observer that it is the best of its class. Rich in quality. a keeper and thick fleshed-such as will sell at sizht. Our strain of the above will produce mainly the type shown in the accompanying cut, which we consider the ideal Hubbard for home or market. Pkt. 5c; oz. 10c; 1/4 1b. 25c ; 1b. $\$ 1.00$.

Mammoth White Bush Scallop. An excellent large strain, earlier than the common stock, creamy white and average double in size: prolific bearer: a splendid variety for market, and the best of all for southern shippers. Pkt. $5 \mathrm{c}$; 0 . $10 \mathrm{c} ; 1 / 4 \mathrm{lb} .20 \mathrm{c} ; 1 \mathrm{~b}$. $75 \mathrm{c}$.

Extra Large Golden Custard Bush Scallop. Decidedly the best strain. It has been selected and grown for years until it has doubled in size, and at tne same time lost none of its other good points, such as earliness quality and productiveness. PKt. $5 \mathrm{c} ; 0 \mathrm{z} .10 \mathrm{c}$; $1 / 4 \mathrm{lb}$. ROc; 1b. 75c.

Giant Summer Crookneck. Double the size of the ordinary Crookneck and very warty; but similar in other respects. Their handsome appearance commands an extra price in the market. Pkt. $5 \mathrm{c}$; 0z. $10 \mathrm{c} ; 3 / 1 \mathrm{~b} .20 \mathrm{c} ; 1 \mathrm{~b} .75 \mathrm{c}$. 
Fordhook. A most excellen'. new Squash, of handsome appearance, yellow outside and straw color within. The flesh is as dry as Pike's Peak and of the most delicious flavor. It ripens early, and is one of the best keepers we know of, it can be kept all through the winter until June. It is very prolific and bug and borer proof. We can highly recommend it to our customers. Pkt. $5 \mathrm{c} ; 0 z .10 \mathrm{c} ; 1 / 41 \mathrm{~b} .25 \mathrm{c} ; 1 \mathrm{~b} . \$ 1.00$.

Marblehead. An excellent Winter Squash. Good keeper, dry and sweet. Pkt. 5c; oz. 10c; 1/4 1b. 20c; 1b. 50c.

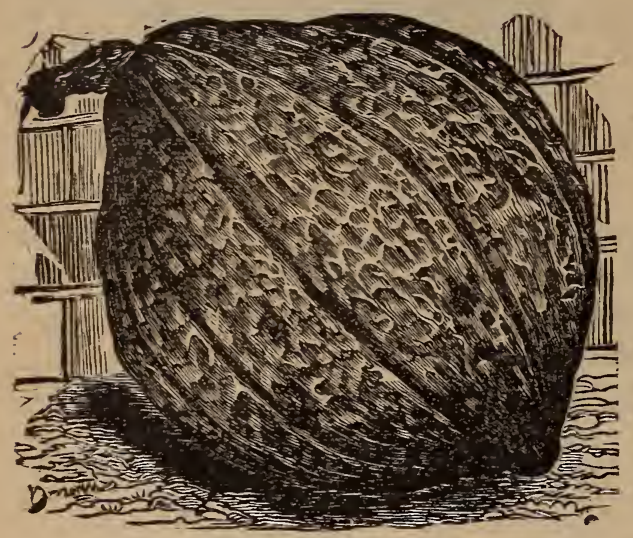

BOSTON MARROW SQUASH.

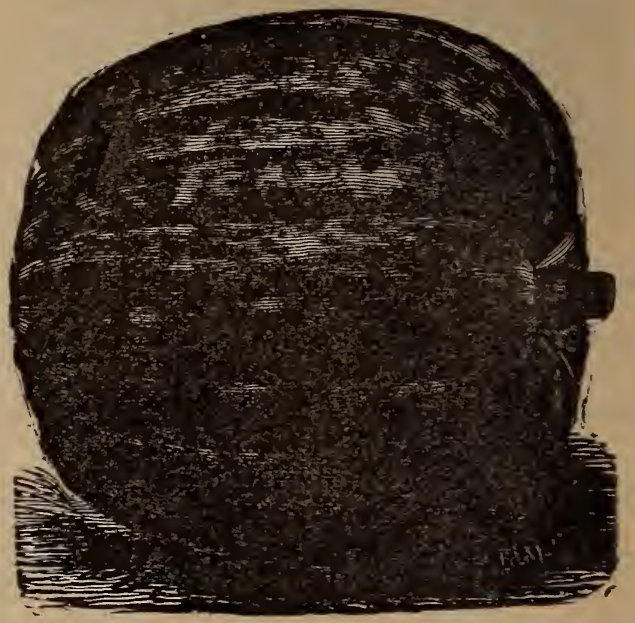

MAMMOTH CHILI SQUASH.

Boston Marrow. Extensively grown and most profitable for Winter use and canning. Flesh orange, fine grained, splendid for pies and as a Winter keeper. Pkt. $5 \mathrm{c} ; 02.10 \mathrm{c} ; 1 / 4 \mathrm{lb} \cdot 20 \mathrm{c} ; 1 \mathrm{~b} .5 \mathrm{Cc} ; 5$ lbs. and over $40 \mathrm{c}$. per 1b.

Mammoth Chili. True stock ("Jumbo"). The "big" exhibition Squash, the largest of all, often weighing over $200 \mathrm{lbs}$. There is a record of one Squash having been grown that weighed 292 pounds. The flesh is very thick and a rich yellow color, skin smooth and bright orange color. Pkt. $5 \mathrm{c} ; \mathrm{oz} 10 \mathrm{c} ; 1 / 1 \mathrm{~b} .30 \mathrm{c}$; 1b. 80 c.

\section{NORTHERN GROWN SELECTED TOMATO SEED.}

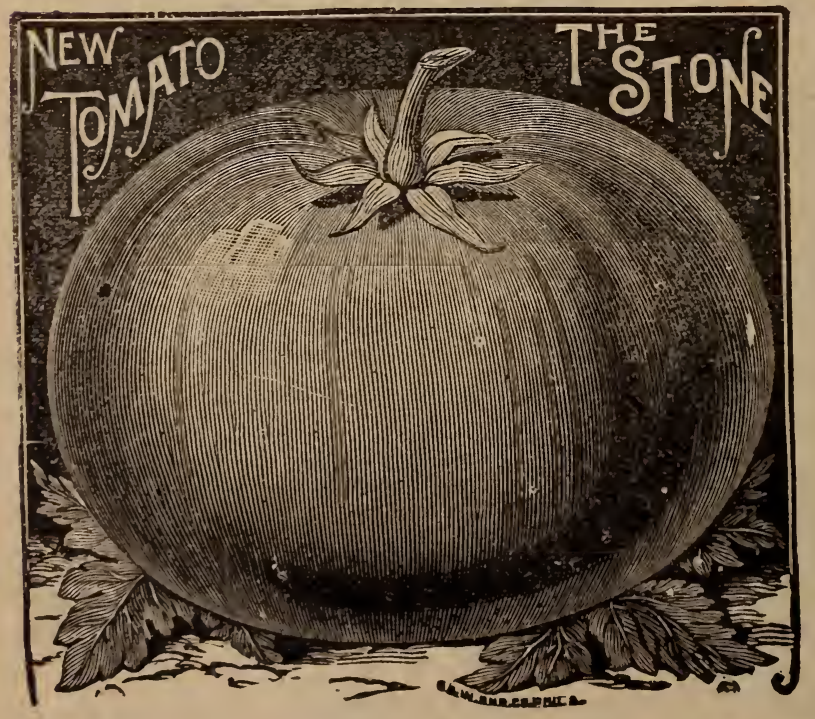

CULTURE.-For early use sow in February, in boxes or pots. and place near a window or in a hotbed. When about two inches high, pick them out singly in small pots and nurse carefully in frames; when danger of frost is past, plant out in sheltered situation, where they may have full influence of the sun. To hasten maturity of the first fruit which sets, pinch off extremities of the tops. One ounce will produce about thirteen hundred plants.

The New Stone Tomato. This new Tomato has already been generally adopted by canners and market gardeners everywhere. Its solidity and carrying qualities are far in advance of any other sort now known; color rich red, shape perfectly smooth and thicker from stem to blossom end than most varieties, making it very desirable and saleable. Very large in size and very heavy cropper. Pkt. 5c; $3 / 4 \mathrm{oz}$. $15 \mathrm{c}$; 0z. $25 \mathrm{c}$; 1 1b. $50 \mathrm{c}$; $1 \mathrm{~b} . \$ 1.75$.

We have no old Seeds in our building whatever. All New stock. 


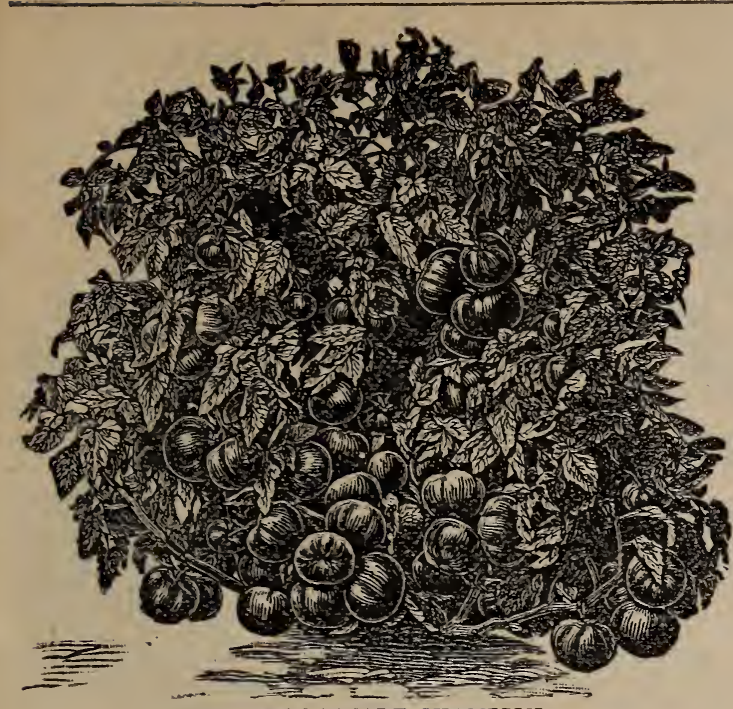

New Dwarf Champion In form and color the fruit closely resembles the Acme; it is always smooth, symmetrical and attractive in appearance, the skin is tough and the flesh solid, ripens well close round to the stem, and is not so much subject to crack as some other sorts. Pkt. $5 \mathrm{c}$; $1 / 2$ oz. $15 \mathrm{c}$; oz. $25 \mathrm{c} ; 1 / 4$ 1b. $60 \mathrm{c}$; 1b. $\$ 2.25$.

Selected Ear'y Acme. Ripens evenly, of med. ium, uniform size, round, very solid and of a pink purplish color, very productive, bearing until killed by frost. Pkt. $5 \mathrm{c} ; 0 z .15 \mathrm{c} ; 1 / 4 \mathrm{lb}$. $50 \mathrm{c}$; lb. $\$ 1.75$.

Early Favorite. A large, smooth, perfectshaped Tomato, of a dark red color, does not rot or crack, ripens early, very prolific, good flavor, flesh solid, has few seeds, very early, good shipper. Pkt. $5 \mathrm{c}$; oz. $15 \mathrm{c}$; $1 / 4$ lb. $50 \mathrm{c}$; lb. $\$ 1.75$.

New Beanty. Well named. Fruit large and showy, color deep red, with a slight tone of purple; growing in clusters. Solid, meaty, smooth, and free from rot or green core, a good sort for shipping on account of its solidity and toughness of skin. Certain to give satisfaction. Keeps well. Pkt. $5 \mathrm{c} ; 0 z .15 \mathrm{c} ; 1 / 4 \mathrm{lb} .50 \mathrm{c} ; 1 \mathrm{~b} . \$ 1.75$.

Perfertion. It is one of the earliest, ripening evenly, a good keeper, color blood red, almost round in shape, perfectly smooth and solid, having few seeds, very produotive, gcod shipper. Pkt. $5 \mathrm{c} ; \mathrm{oz} .15 \mathrm{c} ; 1 / 4 \mathrm{lb} .50 \mathrm{c}$; 1b. $\$ 1.75$.

Now Peach. The most distinct Tomato everintroduced; the fruit resembles the peach in shape and colorwhich is deep rose and amber, the flavor is $r \in$ markably fruity and delicious. Pkt. $5 \mathrm{c} ; 0 z .25 \mathrm{c} ; 1 / 41 \mathrm{~b} .60 \mathrm{c}$; 1b. $\$ 2.25$.

Golden Queen: Specially recommended for canning, for eating raw, or slicing as a table fruit, somewhat resembles the Trophy in appearance. It will please you. Pkt. $5 c$. oz. $25 \mathrm{c} ; 1 / 4 \mathrm{lb} .65 \mathrm{c} ; 1 \mathrm{~b} . \$ 2.50$.

Royal Red. Royal Red is a first-class main crop variety for the shipper, market and private gardener; of special value to the canner and catsup maker. Pkt. $5 \mathrm{c} ; 02.20 \mathrm{c} ; 1 / 4 \mathrm{lb} .60 \mathrm{c} ; 1 \mathrm{~b} . \$ 2.00$.

New Buckeye State Tomato. A fine new extra large sort, nearly one half larger than the Beauty, deep colos, heavy and of splendid quality. Pkt. $5 \mathrm{c} ; 0 \mathrm{z} .20 \mathrm{c} ; 1 / 41 \mathrm{~b} .65 \mathrm{c} ; 1 \mathrm{~b} . \$ 2.25$.

Yellow Plum or Pear. A small yellow variety used for pickling. Pkt. $5 \mathrm{c} ; 0 \mathrm{z} .20 \mathrm{c} ; \mathrm{T} / \mathrm{lb}$. $75 \mathrm{c} ; 1 \mathrm{~b} . \$ 2.50$.

Ponderosa. In growing we have found it of immense size, solid, almost seedless, and of good sub-acid flavor The single fruits were large, but somewhat scattered on the vine, and did not yield near so much as the Beauty and other varieties. Pkt. $5 \mathrm{c} ; 0 z .30 \mathrm{c} ; \mathrm{r} / \mathrm{l} \mathrm{lb} . \$ 100 ; 1 \mathrm{~b}$. $\$ 3.50$.

\section{Mansfield Extra Early Tree Tomato.}

This varifty has been originated by careful selections and special methods until it has attained the height of ten feet for the tree, and a weight for a single tomato of thirty ounces, and six inches in diameter, with testimonials of over sixty pounds of ripe fruit to a single tree, of a quality that surpasses all others. Fruit ripens from July 4 th until frost; they are solid all the way through as a hard-boiled egg, and but few seeds in a tomato. Pkt. $10 \mathrm{c} ; 1 / 2 \mathrm{oz} .15 \mathrm{c} ; \mathrm{oz} .25 \mathrm{c} ; 1 / 4 \mathrm{lb} .80 \mathrm{c}$.

\section{PATENT TOMATO VINE SUPPORTS.}

Price, each, 15 cents; dozen, $\$ 1.50$.

TOMATO PLANTS ready May 1st. Strong transplanted plants. By mail, dozen 25c; 100, $\$ 1.00$; by express, per $100,75 \mathrm{c} ; 1,000, \$ 5.00$.

Send us a trial order. We know you will be pleased with your bargain.

See page 72 for Fertilizers.

See page 75 for Incubators.

See price list Planet Jr. Tools, page 88. 


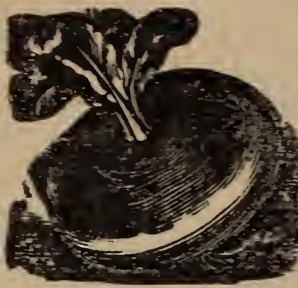

EXTRA EARLY PORPLE. TOP MILAN.

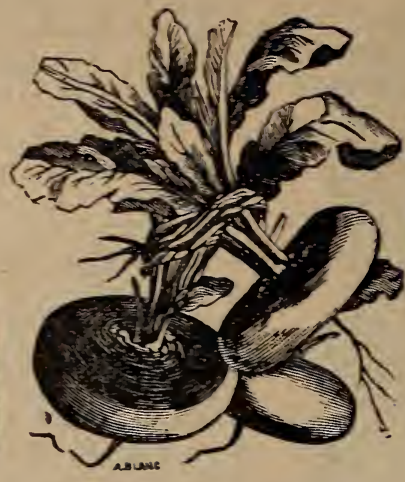

EARLY RED-TOP STRAP LEAF.

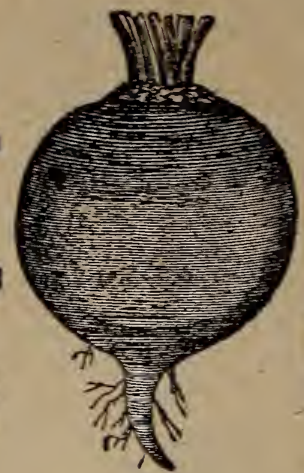

AMBER GLOBE.

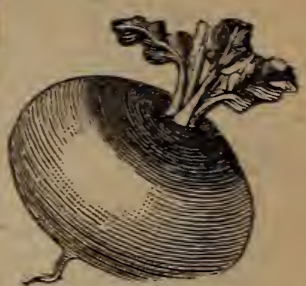

LARGE EARLY PURPLE. TOP GLOBE.

CULTURE.-For early Turnips sow as soon as ground opens in Spring. but the other kinds for Winter use may be sown from middle of July to end_of August. Turnips are generally sown broadcast. but much larger crops are obtained (particularly of Rutabagas) by cultivating in drills 18 inches apart, and thinning to six inches in the drill. The Early White Egg is the Market Gardeners' Turnip. One and one-half pounds to the acre.

Extra Eurly Milan. A new tally rery white variety. with purple-top and strap leaf. Mild and sweet. remain ; in good conditicn for a long time. Choice variety, and as such we recommend it. (Short crop), Pkt. $5 \mathrm{c} ;$ oz. $10 \mathrm{c} ; 4$ oz. $20 \mathrm{c} ; 1 \mathrm{~b} .75 \mathrm{c}$.

Early Flat Red or Purple-Top. (Strap-leaved) The standard for this country. Superior for early or late planting. Round, flat, good sized, smali top, with but few leaves, flesh rery fine grained, flavor good. Pkt. $5 \mathrm{c} ;$ oz. $10 \mathrm{c} ; 4 \mathrm{oz}$. $15 \mathrm{c} ; 1 \mathrm{~b}, 40 \mathrm{c}$.

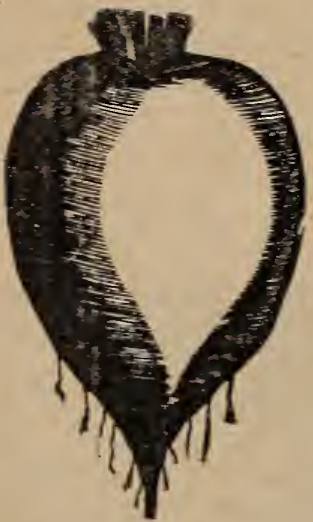

EARLY WHITE EGG.

Amber Globe. This we recom. mend highly, and is almost indispensable in every rural household for its table use or stock. Ikt. $5 \mathrm{c}$; oz. $1 \mathrm{Cc} ; 4$ oz. $15 \mathrm{c}$; lb. $50 \mathrm{c}$.

Large Early Purple-Top Globe. Similar to above, except shape. This is the laigest yielder of any Turnip on the list and very desirable for table or stock. Pkt. $5 \mathrm{c}$; oz. $10 c ; 4$ oz. 1 ic ; lb. 40 c.

Extra Early White Egg Very early and particularly desirable for the table, flesh firm and fine grained. sweet and sugary, and of snowy whiteness, egg-shaped. For Spring or Fall sowing. Pkt. 5c; oz. $10 \mathrm{c}: 4$ oz. $15 \mathrm{c} ; \mathrm{lb} .50 \mathrm{c}$.

Extra Early Dutch. Rather flat, good white early sort. Pkt. $5 \mathrm{c}$; oz. $10 \mathrm{c} ; 4$ oz. $15 \mathrm{c}$; lb. $50 \mathrm{c}$

The Monarch Swede. This new and distinct form of Ruta. bagas, we beliere, by far the best of all. The bulbs are of Tankard shape, with very small neck, skin dark, red above ground and yellow below, flesh rich yellow, fine grained and best quality. For earliness, quality and weight it is superior to any variety in cultivation, producing from two to seven tons per acre more than any other $\mathrm{S}$ wede, while the large percentage of saccharine matler contained in the root makes it very palatable and nutritious to s'ock fed on it. Monarch Swede is of handsome shape and distinct appearance. Fkt. $5 \mathrm{c} ; \mathrm{oz} .10 \mathrm{c} ; 4 \mathrm{oz} .15 \mathrm{c} ; 1 \mathrm{~b} .50 \mathrm{c}$.

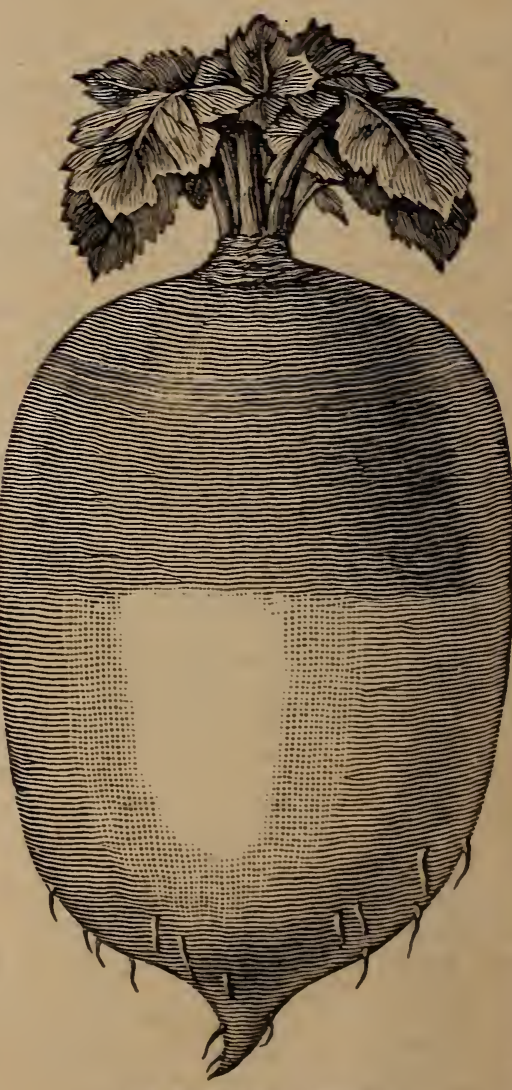

THE MONARCH SWEDE.

Improved American Purple-Top Rntabaga. The leading variety and largely grown for stock as well as family use, hardy. productire, solid sweet. Pkt. $5 \mathrm{c}$; oz. $10 \mathrm{c} ; 5$ oz. $15 \mathrm{c}$; lb. $50 \mathrm{c}$.

Champlun Swede or Yellow Rutabaga. (Imported). A superior English grown Rutabaga, the best to be had abroad. Pkt. 5c; oz. $10 \mathrm{c} ; 40 z .15 \mathrm{c}$; 1b. $40 \mathrm{c}$. 


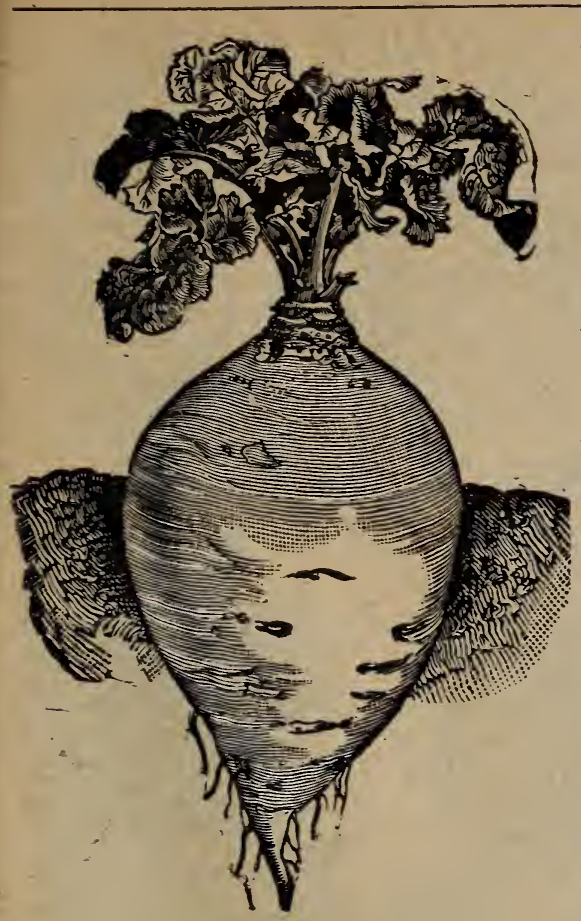

SWEET GERMAN.

Sweet German. This variety partakes largely of the nature of the Rutabaga, and should be sown a month earlier than the flat Turnips. The flesh is white, hard, firm and sweet ; good for Winter and Spring use. Pkt. $5 \mathrm{c}$; oz. $10 \mathrm{c} ; 4 \mathrm{oz} 15 \mathrm{c}$; lb. $50 \mathrm{c}$.

Yellow Aberdcen or Scotch Yellow. This is highly approved as a market and cattle Turnip, attaining a large size. It is sol ' $d$ nutritious a good keeper, and is in every respect splendid for table use. Pkt. $5 \mathrm{c} ;$ oz. $10 \mathrm{c} ; 4$ oz. $15 \mathrm{c} ; 1 \mathrm{~b} .50 \mathrm{c}$.

Early Snowball. Extra early. This is a small white globe, very quick, the earliest in maturity of its form and character. We highly recommend it for table purposes. Pkt. $5 c$; oz. 10c ; 4 oz. $25 \mathrm{c}$; lb. $7 \mathrm{cc}$.

Long Cowhnru. Carrot-shaped. short, of delicate flavor for table. Pkt. $5 \mathrm{c}$; oz. $10 \mathrm{c} ; 4$ oz. 15c; 1b. 50c.

Pomeranian White Globe. (Strap-leaved). This is a freegrowing, rough-leaved sort, useful for both table and stock, and may be recommended for both purposes. Pkt. $5 \mathrm{c} ; \mathrm{oz}$. 10c; 4 oz. 15c; 1b. 45̃c.

Golden Ball. A small yellow turnip of second size, early and a good keeper, very good for market and table. Pkt. $5 \mathrm{c} ; \mathrm{oz}$. $10 \mathrm{c} ; 1 \mathrm{~b} .45 \mathrm{c}$.

\section{HEDGE SEED.}

CULTURE.- Hedge Seed must be soaked in warm not hot water, from five to ten days. Stir each day and change water, and when the seed begins to sprout it is ready for planting. Plants should be transplanted before setting in hedze row.

Osage Orange 40 cents per $1 b$.

\section{SEEDS OF SWEET, POT AND MEDICINAL HERBS.}

Aromatic Herbs are those which possess medicinal as well as culinary properties, and should he found in every garden. They impart a pleasant, spicy odor, and are quite savory to the taste. To secure the herbs for use cut them on a sunny day, and spread thinly in the shade to dry.

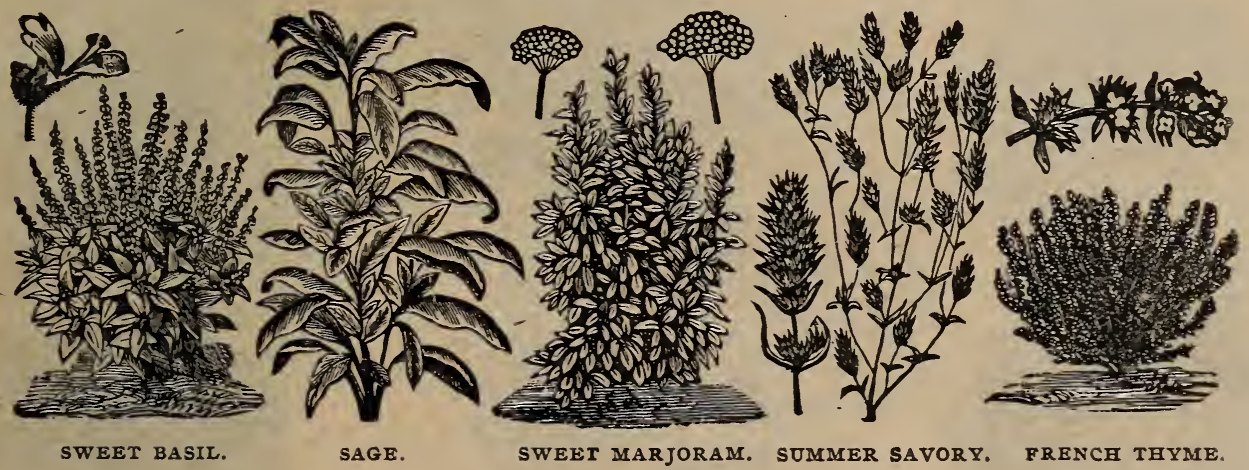

Pkt. Oz.

Anise $(A n i s)$; cordial flavoring 515 Balm (Melisse) : medicinal use................. 5 Basil, SWerl (Bosilicum) ; soups, sauces ..... 5 \$5 Borage (Gerkenkraut); bee feed. salad...-.-. 5 - 25 Caraway (Kuemmel); grown for its seed .... 510 Catnip - _._............. 5 Chervil (Kerbel) -............................... 515 Coriander (Koriander); for confections ..... 510 Dill (Dill) : leaves for soups; seed-flavoring, 515 Fennel (Fenchel) : used in fish sauces _._.__ 515 Horehound; used medicinally.
Pkt. Oz J.avender (Spiklavendel) : medicinal uce..... 525 llarjoramSweer. (Majoram); flavoring ..... $5 \quad 25$ Rosemary (Rosmarin) : ornamental ..-_-..-.- 540 Rua (Route); for medicinal purpo-es _____... 525 Sage (Sa,bis); for sausages and sauce ......... $5 \quad 25$ Suffron (Safran); medicine and dyeing _.....- $5 \quad 25$ Snmmer Savoiy (Bohnenkraut) _.............- 525

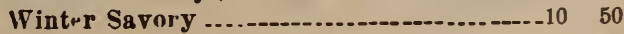
Garden Sorrel (sauerampfor) Sweet'Thyme (Thymion ; for seasoning -..- 535 Wormwood (Wein.wh) _.................... 5. 30 


\section{POPULAR AND CHOICE FLOWER SEEDS.}

Our Flower Seeds are the besi that can be procured from the best growers in America and Europe. Our list comprises nearly all the varieties that can be successfully grown by the average cultivator, omitting such as require the skill of a veteran, and special facilities. Cultural directions are printed on each package, together with a correct illustration in colors. The Seed we offer can be fully relied upon as fresh and pure. We have more and rare rarieties not embraced in this list; if any others are wanted we are able to supply them. Send us your order for any others you may want, not mentioned in this list.

On al! orders for Flower Seeds in packets. the purchaser may select twenty-five cents worth extra for each One Dollar sent us. Thus anyone sending $\$ 1.00$ can select seeds in packets amounting to $\$ 1.25 ;$ for $\$ 2.00$ Seeds in packets to the value of $\$ .50$.

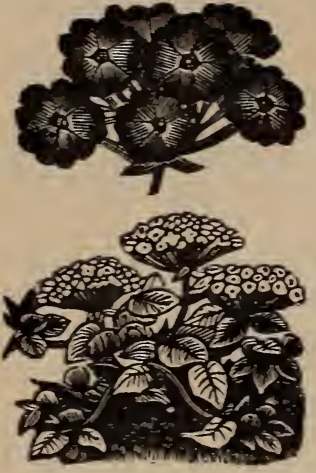

ABRONIA TMBELLATA.

Very pretty trailing plant.

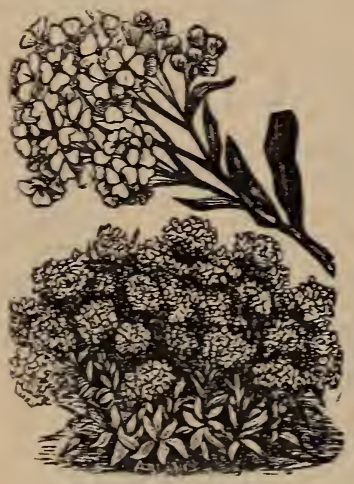

ALYSSUM, SWEET.

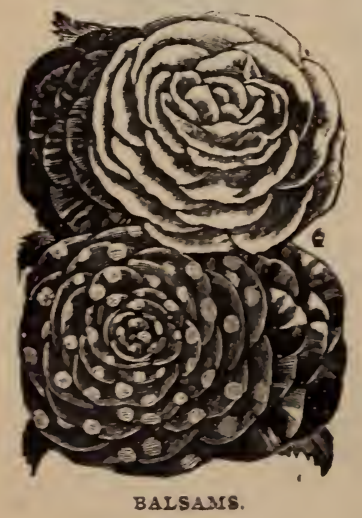

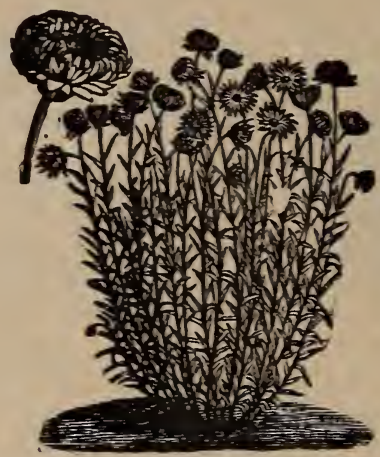

ACROCLINCM (EVERLASTING.)
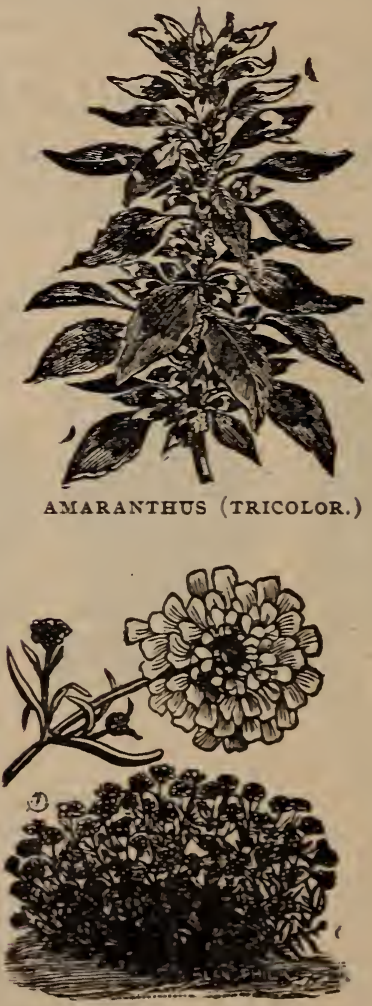

CANDTTERT.

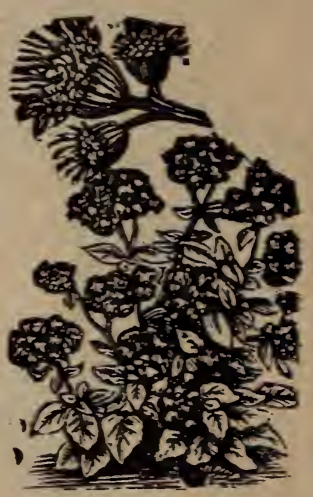

AGERATUM MEXICANUM.

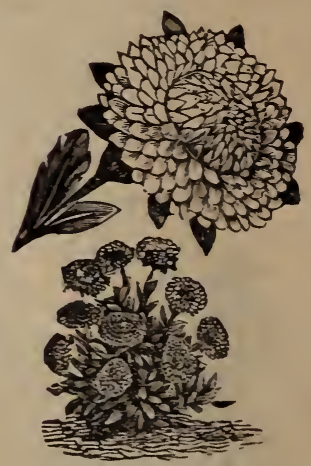

ASTER (ROSE FLOWERED.)

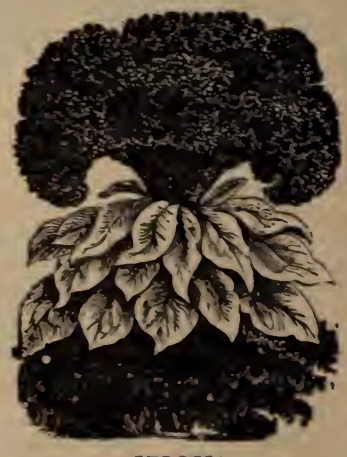

CELOSIA.

Price per Pkt.

Alyssum, Sweet Maritimum ........................... $5 c$ Amaranthus, Melancholius Ruber ................ $5 c$ Amaranthus, Tricolor........................ $5 c$

Antirrhinum, Suap Dratgon ........................ $5 c$
Abronis Umbellata, sweet scented lowers ........ Sc Acroclinum Rosum ............................... 50 Acroclinum Rosum............................ $5 c$ Agteraturn Mexicanum ....................... $5 c$ 


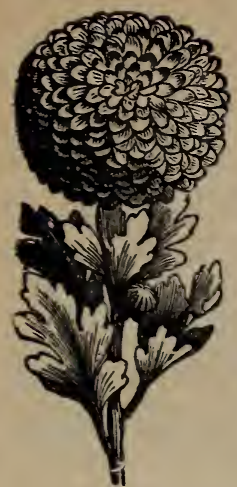

CERYSANTHEMUM

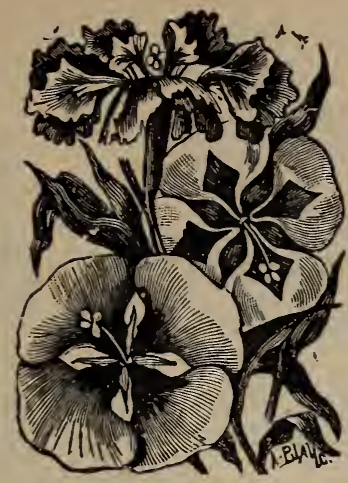

CLARRIAS.

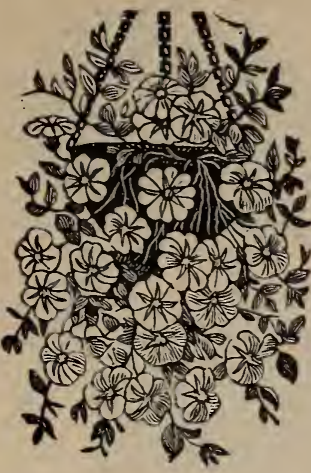

CONVOLVOLOS MAJOR.

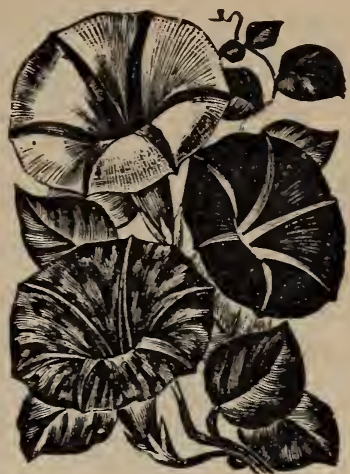

CONVOLVULUS MINOR.

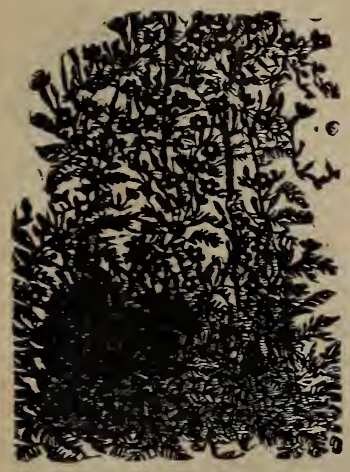

CYPRESS VINE.

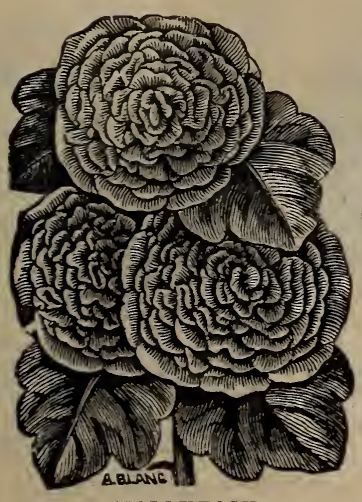

HOLLYHOCK.

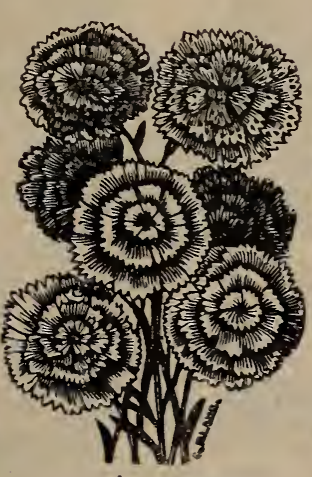

DIANTEUंS CHINENSIS.

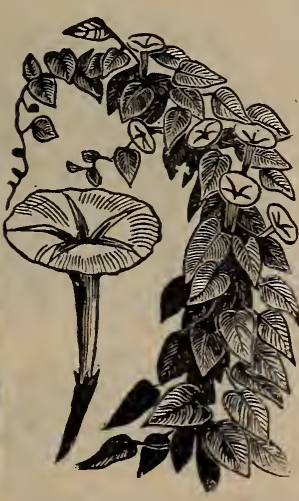

IMPOMOEA BONO NOX.

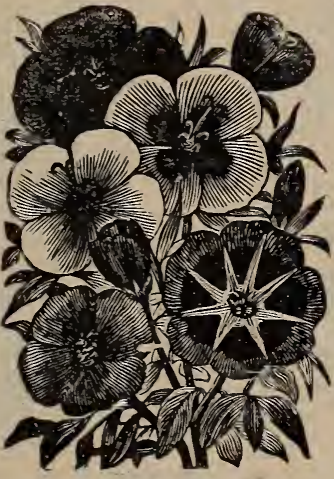

GODETIAS.

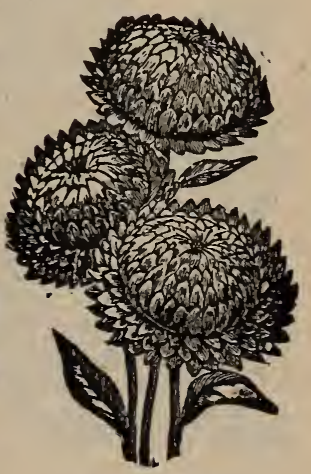

HELICHRYSOM.

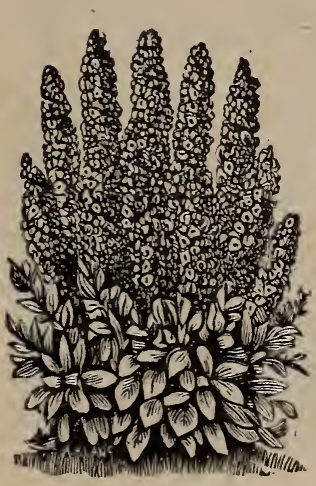

LARKSP OR.

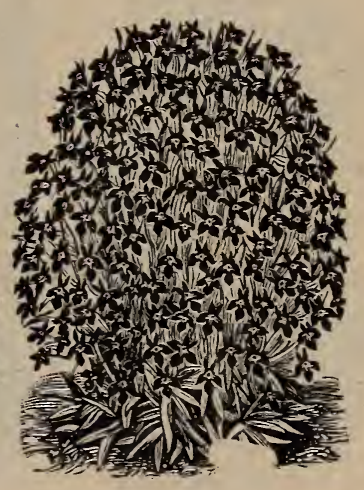

LOBELIA, BLUE GEM.

Price per Pkt.

Antirthinum, dwarf, mixed

Price per Pkt

Cockscomb. Japan, mixed Cosmos, $w$ hite, pink and mixed ................. $5 c$

Convolvulus, Major, mixed...._._............... $5 \mathrm{c}$

Convolvulus, Minor ........

Coreopsis, mixed.................

Cypress Vine, mixed

Chrssant hemum, double yellow _............... 56

Chrysanthemum, white

Chrysanthemum, mixed .........

Dianthus Chinensis ............

Forget. Me-Not, mixed $\ldots$

Gaillardia, mixed.....................

Globe Amaranth ............

Helichrysum, double, mixed, tall and dwarf ..... $5 \mathrm{c}$

Heliotrope, mixed.... $5 c$

Holly hock, double mixed ....

Hyacin $1 \mathrm{~h}$ Bean ....... ...

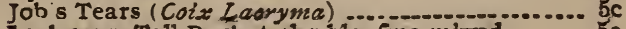

Larksprur; Tall Rooket, double; fine mixed ........ 5c 


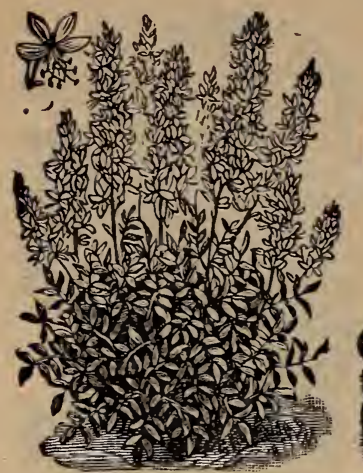

LUPINUS.

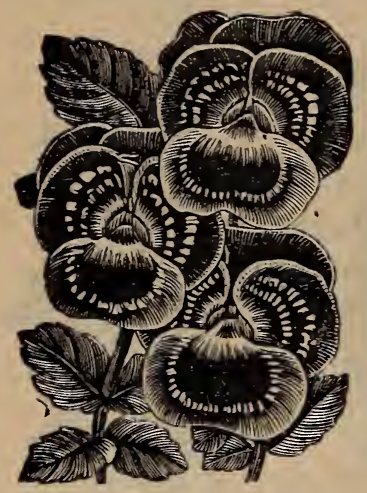

PANSY PERFECTION.
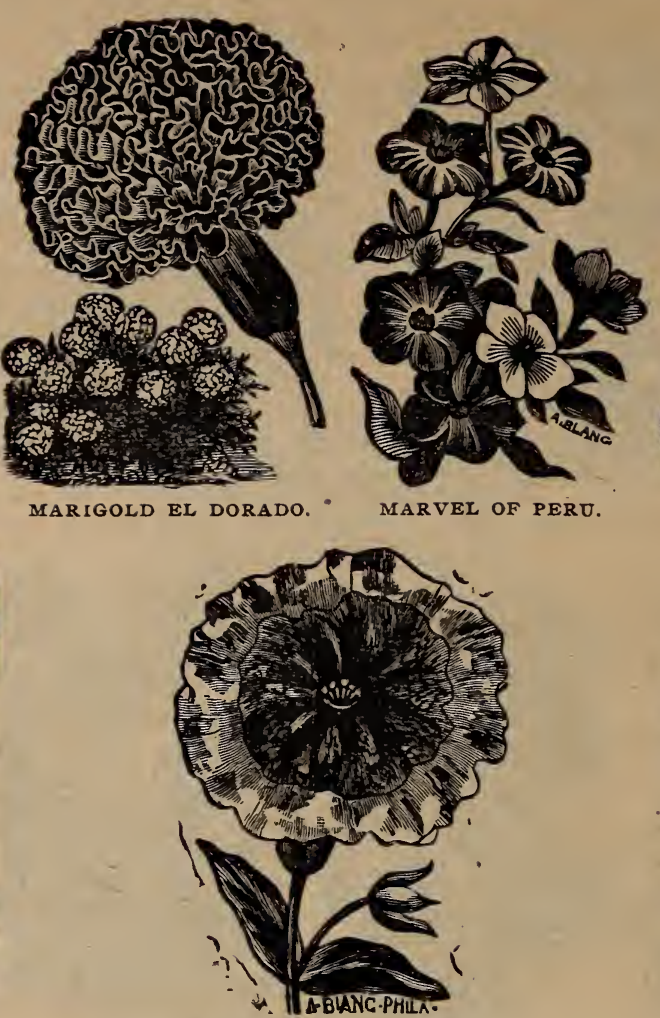

PETUNIA (GRANDIFLORA MARGINATA.)
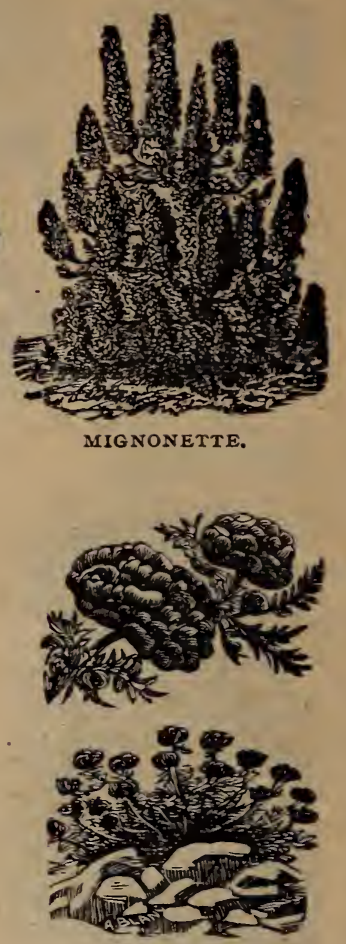

PORTULACA, DOUBLE.
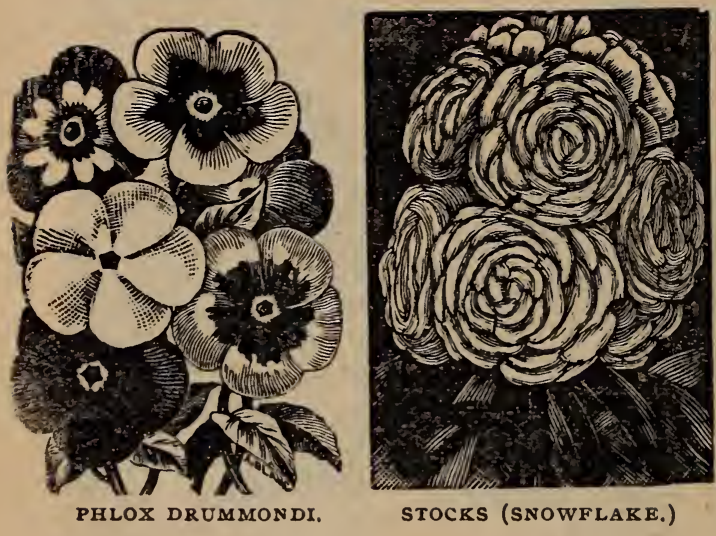

STOCKS (SNOWFLAKE.)

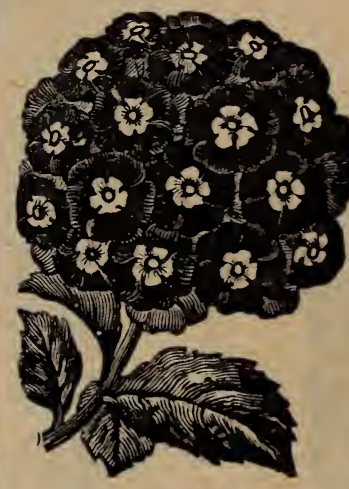

VERBENA, MAMMOTH,

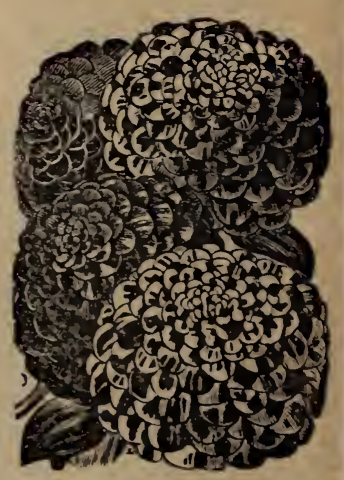

ZINNIAS (ZGBRA.)

Price per Pkt.

Larkspur, Dwarf Rocket, double, fine mixed..... 5c Larkspur, branching. double, fine mixed........ 5c

Lathyrus Latifolius-Everlasting Pea _.............10c

Lobelia Gracius blue.... . ................... 5 c

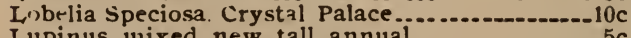

Lupinus uixed. new. tall, annual _............ $5 \mathrm{c}$

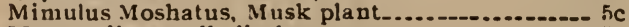

Mauraudia small climber.....

Marigold Atrican

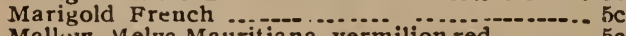

Mallow Melva Mauritiana, vermilion red ......... 5c

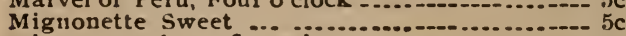

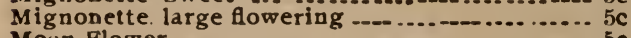

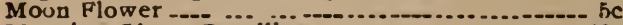

Morning Glory, Brazilian _..................... 10 c

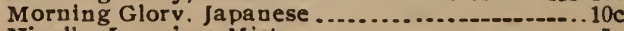

Nigella, Love-in-a-Mist ....................

Noleno mixed.

Pansy. Imperial, German, mixed ............... bc

Pensy, mixed English

Price perPkt.

Petunias, choice mixed .................... $5 \mathrm{c}$ Petunia, new double fringed.. ..................25c Phlox Drummondi, mixed or separate color ..... $5 \mathrm{c}$ Phlox, large flowering .................. 19c Puppv, double mixed ...............

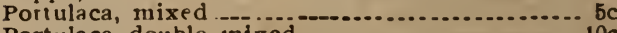
Portulaca, double, inixed........................ Portulaca, single mixed _... ................. $5 \mathrm{c}$ Primula Chinensis. fine mixed ..................... Ricinus Zanziharensis, mixed ....................... Scabiusa mixed, Morniug Bride__._._.......... $5 \mathrm{c}$

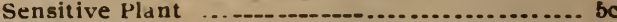

Stocks. ten weeks, mixed..... Stocks, large flowering Sweet William nixed .................. Thunbergia mixed..................... Verbena, mixed hybrid new choice varieties .... 10c Verbena, good mixed varieties .................... $5 \mathrm{c}$ Violets mixed...... Wall Hlower

Zinnia, double mixed .............. 


\section{ROSES AND FRUIT PLANTS.}

We catalogue a line of choice tested novelties in ROsES and PLANTS, guaranteed true to name, and do not think plants their equal can be had of any other seedsman at less price.

OUR ROSES are selected with the utmost care, and our list comprises none but the very best sorts obtainable.

PLANTS BY MAIL. Many of our customers who order Seeds and P'ants at the same time, early in the season and not wanting the plants, can have them held here until planting time, and we will exercise our best judgment as to when and how to send them, so that they will arrive in first-class condition.

WE GUARANTEE ALL PLANTS to arrive safely to any Postoffice in the United States, and to be alive and in good condition for growing. Any complaints must be made within 10 days after receipt of plants, but we cannot be held responsible for plants dying afterwards from neglect or other causes.

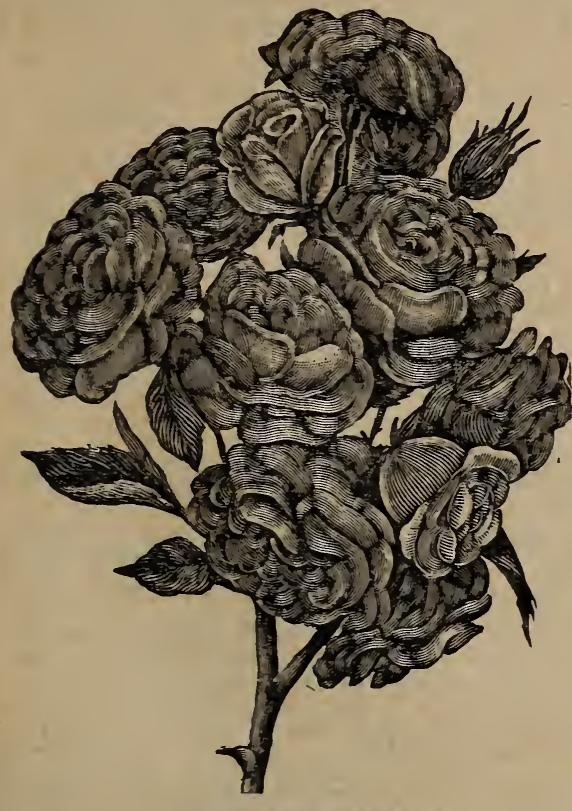

DOROTEY PERKINS.

\section{HARDY MEMORIAL ROSES.}

\section{FOR CEMETERY PLANTING.}

These are hvbrids of Rosa Wichuriana-the Memorial Rose -and are of the same rapid creeping habit of growth. They are valuable for covering the ground, stumps of trees, pillars, posts, trellises, rocky slopes, gravelly embankments, growing where other roses could not possibly live They are absolutely has dy and will survive the severest winters, growing outdoors in any climate, soil exposure, remaining evergreen up until Christmas. The flowers are borne in the utmo-t profusion, a two or three year old plant producing thousands of most $+x$ quisite blossoms, which are delightfully fragrant and which hold their form a long time after cutting. Be sure to include a collection in your order.

Dornthy Perkins. This new Hybrid Rose has been test ed for three years and we are thoroughly convinced of its superiority over any other rose in its class Perfectly hardy as they passed thr sugh last winter, when the temperature went as low as 20 degrees below zero, and with not the usual snowfall to protect them. The flowers are large sized for this class of rose, and borne in clusters of from 6 to 10, and are double: the petals are very prettily rolled back and crinkled. the buds are remarkably pretty, being pointed, and just the size for the button hole. The flowers are sweetly scented : color clear shell pink and holds a long time without fading. Foliage, deep rich green and its nat ural habit is to trail flat along the ground, although it can be trained over arches and other supports. This Rose, like the other hardy memorial Roses here mentioned, is the best for planting in cemeteries. Price. each, 30c. 4 for $\$ 1.00$ postpaid

Double White Memorial Kose (Ianda's Triumph). A new Hybrid Wichuriana of remarkable beauty. The flowers are medium size, perfectly double to the center, pure white and very fragrant.

South (Orange Perfection belongs to the same class as the above; blooms freely in clusters. Color, rosy blush, changing to white; the flowers are perfect rosettes in form, very pretty and entirtly distinct from all others.

Double Pink Memorial Rose (Universal Favorite). Same as the Double White, except in color, which is clear bright piuk; equally as beautiful as the Double White, and a charming companion for it.

Pink Roamer A more rampant grower than the others, and seems to combine the beauty of the Sweet Briar with the Wichuriana The flowers are single, and from two to three inches iudiameter; tich pink, with silver white center and orang-red stamens; exceedingly fragrant and picturesque.

Price of each of the last five Memorial Roses, $15 \mathrm{c}$. each, or one each of the five sorts for $60 \mathrm{c}$.

\section{SIX HARDY CLIMBING ROSES.}

Climbing Roses can be enjoyed everywhere, and the folıwing varieties endure the most trying zero weather and are covered with a mass of bloom in the Spring:

Bultimose Belle. Produces very double flowers in large clusters. Color, pale blush, shading to rose color. Price, $15 c$. each; 3 for $35 c ; 6$ for $65 c ; 12$ for $\$ 1.25$.

Grevil.e or Seven Sisters. Flowers are produced in large clusters. They vary in color from white to crimson. Price, 15c. each; 3 for $35 \mathrm{c} ; 6$ for $65 \mathrm{c} ; 12$ for $\$ 125$.

Queen of the Prairies. Ctear, bright pink; sometimes with a white stripe. Very double, full and bloom in clusters. Price, $15 \mathrm{c}$. each; 3 for $35 \mathrm{c} ; 6$ tor $65 \mathrm{c}$. 12 for $\$ 1.25$.

Russell's Cottuge. Dark velvety crimson; very double, full and a profuse bloomer. Price, 15c. each; 3 for 35 c : 6 tor 65 ; 12 for $\$ 125$.

Tennexsee Belle. A strong, vigorous climher and free bloomer. Bright rosy blnsh: large, full and fragrant. One of the very best. Price, 1 ix each. 3 tor $3 \hat{c}$; 6 for $65 \mathrm{c} ; 12$ for $\$ 1.25$.

Mary Wishington. A hardy, perpetual blooming climber. The flowers are pure white, perfectly double to center, sweet and borne in endless numbers all Summer. The most valuable Rose for outdoor culture. We have the genuine stock to offer at the following prices: $15 \mathrm{c}$. each ; 3 for $40 \mathrm{c} ; 6$ lor $75 \mathrm{c} ; 12$ for $\$ 1.40$. 


\section{FIVE NEW JAPANESE RAMBLER ROSES.}

Helene. This is a Rose novelty that we can strongly recommend. It originated with a German rosarian who claims it to be an improvement in many ways over its wonderful parent the Crimson Rambler. It is of very robust growth. throwing up canes 10 to 15 feet high in a single season. Foliage thick, leathery texture and glossy appearance, and is less subject to mildew than the Crimson Rambler, and withstands the Northern winters better. Flowers, pure soft violet rose, almost blush: base of petals yellowish and borne in clusters of 25 to 50 . Try it Price, $25 \mathrm{c}$. each; 3 for $60 \mathrm{c} ; 6$ for $\$ 1.00 ; 12$ for $\$ 1.75$.

New Crimsnn Rambler. This splendid Rose is now well known and brings big prices to florists everywhere. Produces 25 to 30 flowers in a cluster, entirely covering the plant from the ground to the top with a mass of bright glowing crimson. Price, $20 \mathrm{c}$. each; 3 for $40 \mathrm{c} ; 6$ for $75 \mathrm{c} ; 12$ for $\$ 1.25$.

New Yellow Rambler. An absolutely hardy yellow climbing Rose. The flowers are of moderate size and last three or four weeks without fading, and are frequently borne in clusters of from 130 to 150 flowers. Price, 20c. each : 3 for $50 \mathrm{c} ; 6$ for $75 \mathrm{c} ; 12$ for $\$ 1.25$.

Now Pink Rambler. Color, a clear light red, with numerous golden antlers. A very profuse bloomer and vigorous grower. Price, $20 \mathrm{c}$. each; 3 for $40 \mathrm{c}: 6$ for $76 \mathrm{c} ; 12$ for $\$ 1.25$.

New White Rambler. Pure white, otherwise similar in every particular to Yellow Rambler. Price, $80 \mathrm{c}$. each.

\section{LOR D PENZANCE'S.}

Hardy New Hybrid Sweet Briars. Foliage sweetly scented like the old fashioned Sweet Briar Roses that grew in our grandmothers' gardens, We offer the best three kinds-Red, Pink and White. Price, 20c. $\epsilon$ ach, or one each of the above for $50 \mathrm{c}$.

\section{SEVEN GOOD ROSES OF SPECIAL MERIT.}

Caroline Marniesse. This is a perpetual bloomer, even in a dry season wben other so-called perpetual bloomers show scarcely any blossom the purchaser of this variety may expect a continuous mass of bloom. They are perfectly hardy and produce medium size very double flowers, very sweetly scented. Price, $15 c$. each; 3 for $40 \mathrm{c} ; 6$ for $75 \mathrm{c} ; 12$ for $\$ 1.40$.

The Clin Rnse. Produces flowers of a beautiful flesh color, and has the most delicate texture and coloring imaginable. The plant is a hardy, vigorous grower and produces flowers in abundance, many being 6 inches in diameter. Price, $15 \mathrm{c}$. each; 3 for $40 \mathrm{c} ; 6$ for $75 \mathrm{c} ; 12$ for $\$ 1.40$.

Empress of China. This is a new and valuable perpetual blooming climber. It commences flowering the first of May and except under some especially trying circumstances, such as long drouths. it will bloom repeateilly until late fall. Flowers are small, fragrant, delicate and waxy. Bud is a dark red, changing to a red or pink, like an apple blossom. Price, $15 \mathrm{c}$. each; 3 for $40 \mathrm{c} ; 6$ for $75 \mathrm{c} ; 12$ for $\$ 1.40$.

Helen Keller. $(N e w)$. The plant is a vigorous grower and produces brilliant rose-colored flowers in great abundance from ea rly spring until fall. Price, $15 \mathrm{c}$. each; 3 for $40 \mathrm{c} ; 6$ for $75 \mathrm{c} ; 12$ for $\$ 1.40$.

Mrs. Crawford. $(N e w)$. Color is a deep rich pink, outer petals tinted with pale flesh ; flowers are large, full, very fragrant and unique. Price, $15 \mathrm{c}$. each : 3 for $40 \mathrm{c} ; 6$ for $75 \mathrm{c} ; 12$ for $\$ 1.40$.

Marchionesg of Lorne. (New). Large, full, cup-shaped; buds long and handsome ; rich shining rose color with vivld carmine; hardy, very fragrant. Price, $15 \mathrm{c}$. each ; 3 for $40 \mathrm{c} ; 6$ for $75 \mathrm{c} ; 12$ for $\$ 1.40$.

Margaret Dirkson. A seedling, the flower is of magnificent form very double and the color is a waxy white ; petals are large shell-shaped and prettily curled back; very beautiful. Price. 15c. each. 3 for $40 \mathrm{c} ; 6$ for 75 ; 12 for $\$ 1.40$.

Cumberland Belle. New Climbing Moss Rose. The only climbing variety in existence. This is the forerunner of a new race of Roses, a grand true Climbing Moss Rose It is of American origin. having been found growing in a private garden in the historic Cumberland Valley-a sport, from that prettv Moss Rose Princess Adelaide, iiself a stroug vigorous grower. which is wonderfully developed in the offspring. the original sport the first season having attained $a$ height of over fifteen feet and had one hundred and eighteen buds and flevers on it at one time. The past season, planted side by side with Crimion Rambler and other rampant growers, it fully qqualed them in vigor of growth. In color it is identical to the parent, a bright silvesy rose, very double, the buds nicely mossed and exquisitely fragrant. Altogether a most unique and. desirable acquisition.

\section{THREE MOSS ROSES.}

The Moss Rose is a strong, vigorous grower. perfectly hardy and therefore justly esteemed as very desirable for outdoor culture iu open ground.

Blanche Morreau. Is pure white, large and full buds, very mossy and handsome; one of the few Moss Roses that bloom repeatedly throughout the season.

Crimson Globe. A beautiful dark crimson. The open flowers have a fine round form. Buds are mossy and handsome. A strong and vigorous bloomer.

Princesa Adelaide. Light rose pink of good size; the bush is very hardy, reaching a height of 6 to 8 feet. Especially well adapted to forming a hedge, and a more beautiful oue cannot be imagined. Price, 20c. each; 3 for 50 c; 6 for $75 c ; 12$ for $\$ 1.40$.

\section{EVER-HLOUMING BEDDING ROSES.} (TEAS AND HYBRID TEAS.)

These are most popular for bedding: bloom when very small, and. if well cared for, flower continuously during the whole season. Price, 25c. each; 3 for $35 \mathrm{c} ; 6$ for $60 \mathrm{c} ; 12$ for $\$ 1.00$. We offer the following varieties:

Augustine Guinoiseau (White La France). Is fully described in calling it very pale, satiny La France. It is first-class. 
EVER-BLOOMING BEDDING ROSES-CONTINUED.

Aggrippina. Deep crimson; good bedder. The best in its class.

Duchess of Albany (Red La France). Similar to La France, but much darker. A leading forcing Kose in this country.

Etoile de Lyon. Deep yellow, double and very beautiful. A good bedder.

Hermosa. Bright rose, med um or small; hardy. It is continually in bloom; not full; very popular.

Kaiserin A ugusta Victoria. Pure white with yellow center. Very free. A most promising variety, having the form of $C$. Mermet.

Mme. Angelique Veyssex (Striped La France). It promises extremely well. A nicely striped La France.

Mme. Hoste Yellowish white, often canary yellow; base of petals often amber colored. One of the finest forcing varieties.

Mme. Caroline Testout. Flower large. double and globular; clear satiny rose, center brighter. Very fragrant.

Marion Dingee. Deep carmine. Very fine bedder,

Marie Guillot. White, fairly linged yellow, Large, full and of splendid form. One of the most beautiful.

Mrs. Degraw. Resembles Appoline, but more prolific. Glossy pink, fragrant and continuous bloomer. Fine bedder; hardy south of New York.

Meteor. Velvety crimson. The brightest and best of Hybrid Teas, witbout a purple tinge.

Papa Gontier. Very bright rose or red, large, not double; flower extra good. A first-class forcing variety,

Perle des Jardins. Canary yellow : large or very large, full, well formed, stiff stem; very free. The standard forcing Tea, by which all others are compared.

Princess Bonnie. Crimson, inside of petals faintly streaked white.

Pink Soupert. A superb new Tea Polyantha Rose. It is an offspring of Clothilde Soupert pink. The freedom of bloom is marvelous: throughout the entire growing season it produces cluster after cluster of finely formed buds and flowers. It is hardy, with slight protection. For open ground planting, this varitty is conceded to be the best of all Pink Roses It suits everybody and is one of the most popular roses in cultivation.

Safrano. Saffron and apricot; yellow, large, semi-double, beautiful in bud ; very free.

Souv. de la Malmaison. Flesh shaded fawn; large, very full, flat. A fine rose.

Souv. de President Carnot. Long bud of Niphetos shape; flesh color, shaded with rosy white at the edges of the petals. Seeding from Lady Mary Fitzwilliam.

Moselia. (Yellow Soupett). It is remar'sably free blooming, producing in continuous-profusion throughout the growing season, clusters of 3 to 6 flowers, are exquisitely beautiful, very double and of graceful form. the buds are perfect in their shape, and as they open do not jook unlike Camelia flowers; petals are tinted with white on yellow ground, which becomes golden in center of flower. Hardy with protection,

\section{HYBRID PERPETUALS.}

Hybrid Perpetuals should be very extensively grown. They are best suited for garden culture in the North. All varieties given under this class are thoroughly hardy and suitable for planting in beds, burders or hiedges. They furnish deep rich glowing colors, and are i he finest of all roses for vases. Price of any of the following varieties, $15 \mathrm{c}$. each ; 3 for $40 \mathrm{c} ; 6$ for $75 \mathrm{c} ; 12$ for $\$ 1.25$.

Caprice. The flowers are large, ground color soft satiny pink, distinctly striped and dashed with white and carmine. It is beantiful in the bud form, being quite long and pointed, showing the stripes and markings to great advantage, making it a valuable variety for cutting.

Alfred Colomb. Bright carmine crimson; very large, full and of fine globular form.

Anne de Diesbach. Bright rose color; very large and showy; Particularly fine in bud; flowers slightly cupped. A vigorous grower; one of the best.

Baron de Bonstetten. Flowers large, very double and full; color a rich, dark red, passing to a deep velvety maroon; highly scented.

Coquette des Blanches A finely formed pure white rose. occasionally shows ligbt flesh when first opening be + utiful shell-shaped petals, evenly arranged. Flowers of good size, perfect, fine form and finish. One of the finest and most beautiful of the White Hybrids. Very suitable for cemetery planting.

Gen. Jacqueminot. Brilliant crimson : very large, globular and excellent. A free bloomer, unsurpassed in its clear, rich crimson-scarlet color.

Gen. Washington. Perfectly double, large, fine form. Color, soft scarlet, sometimes a glowing crimson.

Madame Plantier. Pure white, a profuse bloomer; is well known and valuable; an "iron-clad" in hardiness; a splendid cemetery rose; unlike the other varieties it skould never be pruned.

Magna Oharta. A splendid sort; bright clear pink, flushed with violet crimson; very sweet; flower extra large fine form, very double and full. A free bloomer.

Marshall P. Wilder. Flowers very large, perfectly double and of good substance. Color, bright cherry red, shading to crimson. The plant is a clean, healthy grower and a very free bloomer.

Mrs. J H. Laing. One of the finest roses of its class. It is very free flowering, commencing to bloom early in the season and continues to bloom freely until Autumn. Color, a soft, delicate pink, with a satin tinge very fragrant. 


\section{CLEMATIS.}

There is no more or namental class of plants than Clematis Flowers; large, measuring 4 to 6 and sometimee 8 inches in diameter. The rich bloom is truly magnificent.

Jackmanni, Purple, deep and velvety. The most popular and most commonly planted.

Duchess of Edinburg. Double and pure white.

Henryii. Has large white flowers; is very handsome.

Madame Edward Andre. This is a valuable new variety of a distinct new color. It is a f ne bright crimson ; the flowers are of good size and borne so profusely that it has been called "Crimson Jackmanni."

Paniculata. White, extremely rapid growth, with large, dark, shining green foliage and a profusion of small, fragrant flowers borne in large panicles. After flowering, the seed-pods assume a bronze tint, contrasting finely with the dark foliage.

Ramona. Lavender blue; flowers are very large, often nine inches across.

Madame Baron Veillard. Is light rose or pink; new and very distinct ; strong grower.

Price, $20 \mathrm{c}$. each ; 3 for $50 \mathrm{c} ; 6$ for $80 \mathrm{c} ; 12$ for $\$ 1.50$. One each of the 7 varieties for $\$ 1.00$, post paid.

\section{GRAPES.}

ORDERS SHOULD BE RECEIVED BY APRIL 1ST.

\section{RED GRAPES.}

Agawam. Bunch large; berries round; dark red or maroon color. Vine very vigorous, hardy and productive. Brighton. Is a vigorous grower; early; bunches large; of rich wine shade color; an excellent variety. Ripens a week to ten days before the Delaware. Delicate skin.

Lindley. Still holds its own as one of the finest grapes; bunches small ; berries round; skin thin, light red : flesh very juicy, without any hard pulp and an exceedingly sweet, spicy and delicious flavor.

\section{WHITE GRAPES.}

Niagara. Vine hardy ; fruit large, mostly round, greenish white color.

Pocklington, Very hardy ; called a White Grape, but the fruit is a light golden yellow.

Moore's Diamond. Color greenish white; berry about the size of Concord; one of the best.

\section{BLACK GRAPES.}

Concord. Bunch and berries large, purplish black; medium early, ripening in september. Largely planted by all.

Worden. Large grape of the Concord type, but earlier, larger in bunch and berry ; very popular.

Moore's Early. Fruit very large, blue-black and free from mildew and disease; a first-class sort.

Price of any of the varieties of Grapes, $15 \mathrm{c}$. each by mail post paid. By express or freight not prepaid $\$ 1.00$ per dozen; $\$ 5.00$ per hundred.

\section{THE RATHBUN BLACKBERRY.}

Is a new fruit that we offer with the ut most satisfaction, knowing that it cannot fail to delight and astonish all who plant it. It is admired by all who have seen it and no one has been able to discover a weak point about it. A giant among its kind; fruit measured $13 / 4$ inches long and $13 / 8$ inches in diameter; 45 berries filled a quart box, while it took I64 berries of Snyder Black heriy to do it

The Rathbun Blackberry has already become known and has established a high reputation, and the fruit

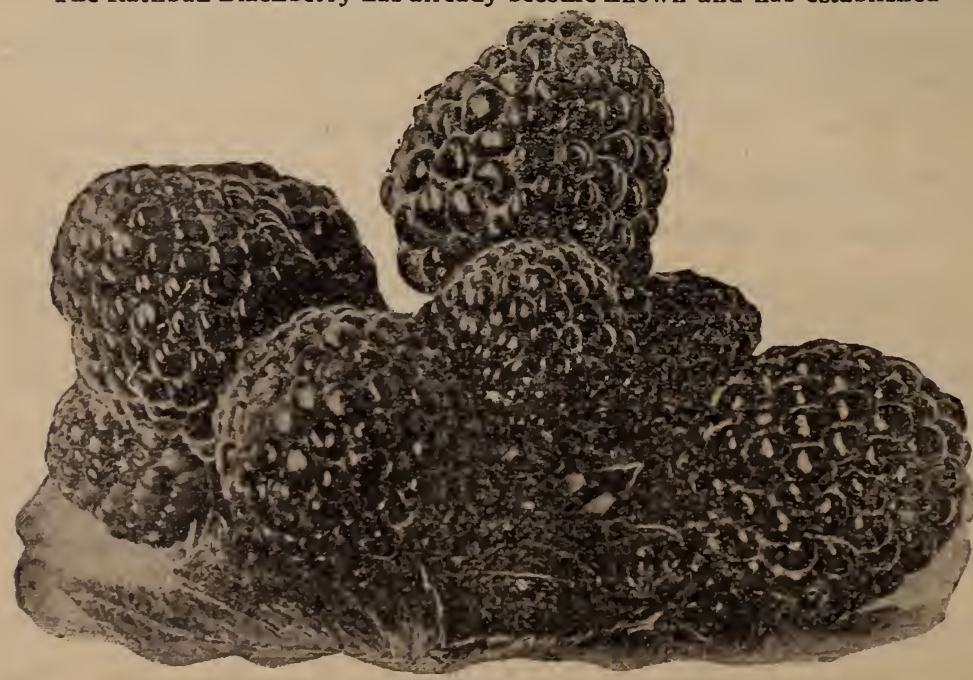
has brought a much high. er price than any other blackberry of its kind at this time. The plant is a strong, erect grower and unlike most varieties produces but few suckers. It is not a Dewberry nor is there the least evidence that there is a mixture of Dewberry in the plant, as no Dewberries were culti. vated on the place or in the neighborhood where it was grown. The fruit in size and general appearance is well illustrated in the aacompanying engraving It grows on long stems in clusters, which enables it to be easily gathered The berries are large and have no hard core of the highest flavor. It has been sent a distance of some 36 miles, by wagon and rail, going through in fine conditiun and selling in pref. erence to the best other varieties in market and THE RATHBUN BLACKBERY

bringing a higher price.

This is a monster Blackberry and all our customers, should send us an order. Cholce plants at $20 \mathrm{c}$. each; $\$ 1.60$ per dozen, by mail post paid. By express or freight not prepaid, $\$ 5.00$ per 100 . 


\section{THE NEW WHITE BLACKBERRY IICEBERG.I}

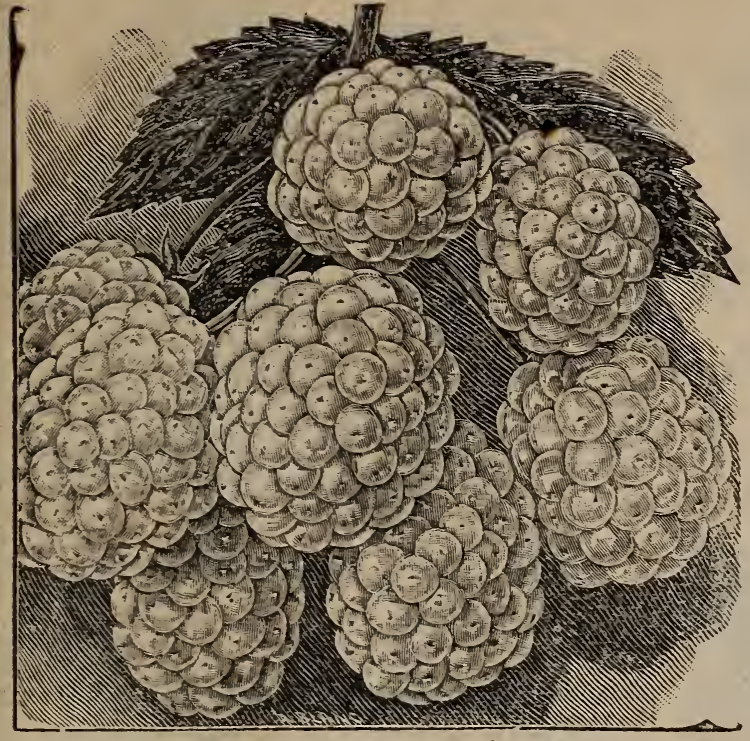

THE NEW WHITE BLACKBERRY (ICEBERG.)

This is something entirely new in fruit and we are sure that all our customers who plant the New White Blackberry (Iceberg) will be more than pleased. The following description is what the originator gives and he does not desire to mislead any one. He says "owing to the somewhat unsatisfactory qualities of white blackberries so far known, the impression may have beell entertained by some that no white blackberry could be as productive and hardy with berries as early, abundant, large and handsome as the best black ones. The well-known Lawton is when ripened unsurpassed and very generally known as the most productive market berry. One of the great grandparents of Iceberg was Lawton; the first generation of seedlings when crossed with Crystal White was all black ; second, also, though very much different in other respects. but the third produced this wonderful plant, bearing the snowiest white berries ever seen. Very little attention was paid to the long rows of crossbred descendants, until one oay this berry was discovered among its black relatives with the cane bending in various directions with their load of delicious snowy berries which are not only white but so transparent, the seeds, which are unusually small, may be seen in the berries when ripe. The clusters are larger than those of Lawton berries, as near as can be judged, they were at least as large, sweeter and more tender." Order a few plants and test them. Price, $20 \mathrm{c}$ each ; $\$ 1.60$ per dozen, by mail postpaid. By freight or express, not paid, $\$ 6.00$ per 100 .

\section{NEW CUMBERLAND BLACK RASPBERRY.}

This is the business black-cap : the largest black raspberry known; the fruit has sold for 10 cents per quart while the other varieties were selling from 5 to 7 cents. The Cumberland was placed upon the market after having been thoroughly tried for a long period of years. The Cumberland is perfectly hardy, it has undergone a temperature of 16 degrees below zero, unprotected, without injury, a temperature which badly crippled similarly situated plants of Gregg, Shaffer, Cuthbert, etc. It is very productive, producing regularly very large crops. In size, the fruit is simply enormous, far surpassing any other variety. The beries run seveneights and fifteen-sixteenths of an inch in diameter. In quality it is similar and fully equal to the Gregg, which has al ways been considered the finest black-cap. The season of ripening varies in different latitudes, following Palmer and Tyler and preceding Gregg, and is what may be ter med a mid-season variety.

Those who are fond of choice berries, should order this new variety, and we can assure all will be pleased.

Price for good strong plants, 15 cents each; 12 for $\$ 1.00$, by mail postpaid. By express or freight not prepaid, $\$ 5.00$ per 100 .

\section{CURRANTS.}

We offer the following varieties: Victoria ; Cherry ; Fay's Prolific ; North Star. Price of good strong two-year old plants, $15 \mathrm{c}$ each, by mail postpaid. By express or freight not prepaid, $75 \mathrm{c}$ per dozen ; $\$ 3.50$ per 100 .

\section{GOOSEBERRIES.}

Downing; Haughton. Each 15 cents, by mail postpaid. By freight or express;not prepaid 75c per dozen; $\$ 6.00$ per 100 .

Columbus; Industry or Red Jacket. Each 10 cents, by mail prepaid. By freight or express not prepaid $\$ 1.25$ per dozen; $\$ 10.00$ per 100 . 


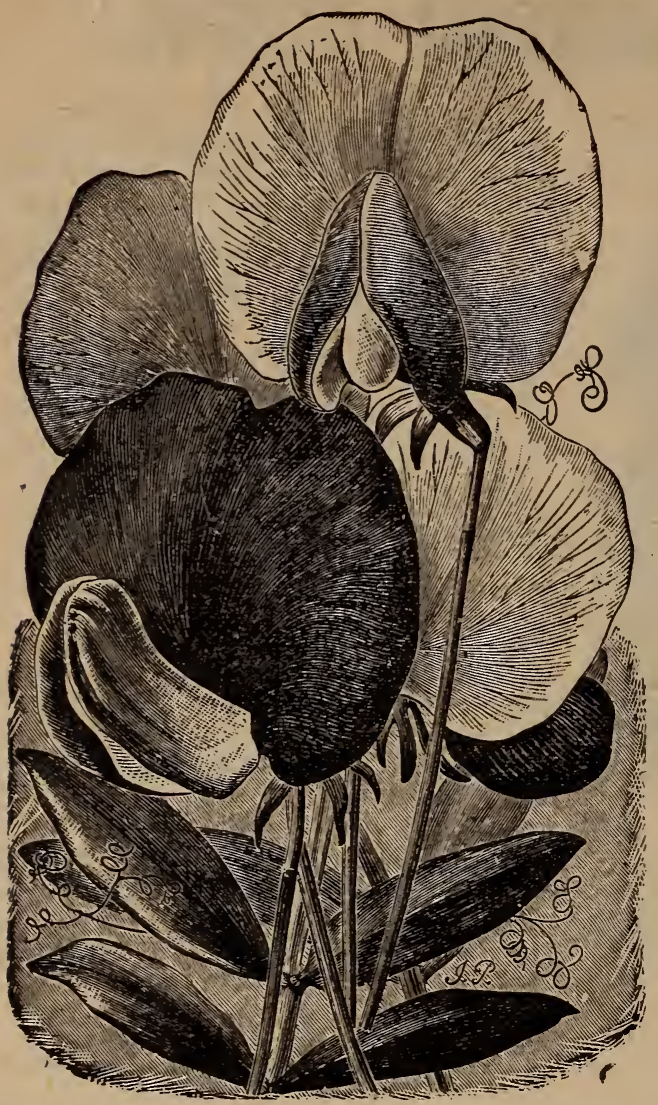

\section{SWEET PEAS.}

\section{(LATHYRUS ODORATUS.)}

These exceedingly beautiful and fragrant hardy annuals are now most popular.

DIRECTIONS FOR COLTURE.-Sweet Peas succeed best in a deep, rich soil. The most approved method of cultivation is to sow in a trench five or six inches deep, covering them at first with only ONE INCH of soil; then as the plants grow, fill in with dirt about them ONE INCB AT A TIME. After the plants are grown up they should be watered copiously and bone meal worked into the soil about the roots is recommended. Proper trellis or other support should be provided.

The first sowing of Sweet Peas may be made very early in the Spring ; as soon as the frost is out of the ground. For a succession some should be sown every few weeks afterwards. For Fall flowering, they may be sown as late as July. By cutting the flowers before they fade, thus preventing pods forming ' the blossoms may be continued the whole season.

\section{Sweet Peas. Named Varieties.}

Apple Blossom. Bright pink and blush; beautifu'ly shaded.

Blanche Ferry. Large pink and white flowers; very early; free flowering.

Boreatton. Crimson purple; very dark large flower. Butterfly. Plain grey, with distinct porcelain edge. Captain of the Blues. Bright purple and pale blue.

Cardinal. Crimson-Scarlet

The above six varieties-price: Pkt. 5c; oz. 10c; 4 oz. 20 c; 1b. 50 c.

Blushing Beauty. Soft pink, suffused with lilac; extra large

Emily Henderson. Splendid pure white; good for forcing.

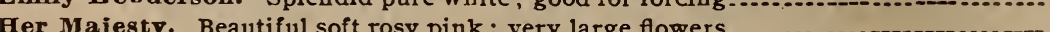

Lady Penzance, Beautifal pale but very bright rose; splendid form.

Monarch. Bronze Crimson and blue; superb flowers.

Mrs. Qladstone. Delicate soft pink, with rosy blush wings.

Painted Lady. Rosy crimson and blush white.

Scarlet Invincible. Flowers large, rich scarlet pink; blooms profusely......-........

Venus. Salmon buff; standards delicately shaded with rosy pink

$\begin{array}{cccc}\text { rkt. } & \text { Oz. } & 4 \text { Oz. } & \text { I,b. } \\ \mathbf{5} & \mathbf{1 0} & \mathbf{2 0} & \mathbf{5 0} \\ \mathbf{5} & 10 & 20 & \mathbf{5 0} \\ \mathbf{5} & 10 & 20 & \mathbf{5 0} \\ \mathbf{5} & 10 & 20 & \mathbf{5 0} \\ \mathbf{5} & 10 & 20 & \mathbf{5 0} \\ \mathbf{5} & 10 & 20 & \mathbf{5 0} \\ \mathbf{5} & 10 & 20 & \mathbf{5 0} \\ \mathbf{5} & 10 & 20 & \mathbf{5 0} \\ \mathbf{5} & 10 & 20 & 50\end{array}$

\section{SWEET PEAS IN MIXTURE-By Mail, Postpaid.}

Philipps' Special Mixtore.-Comprising the finest new and large flowering named varieties. Pkt. $5 c$; oz. $10 \mathrm{c} ; 4$ oz. $20 \mathrm{c} ; 1 \mathrm{~b} .50 \mathrm{c}$

CHOICE STANDARD MIXED VARIETIES. $6 \mathrm{pkts}$. for $25 \mathrm{c} ; 14 \mathrm{pkts}$. for $50 \mathrm{c}: 30 \mathrm{pkts}$. for $\$ 1.00$.

SPECIAL OFFER.-Assorted named varieties. $6 \mathrm{pkts}$. for $25 \mathrm{c} ; 14 \mathrm{pkts}$. for $50 \mathrm{c} ; 30 \mathrm{pkts}$. $\$ 1.00$.

CHOICE MIXED VARIETIEs. 7 pkts. for $25 \mathrm{c} ; 16 \mathrm{pkts}$. for $50 \mathrm{c} ; 35 \mathrm{pkts}$. for $\$ 1.00$.

\section{NEW AND RARE CANNAS.}

Chicago. Nearly 4 feet. Grand Vermillion scarlet; flowers very large and flat, petals broad and five in number, composing a magnificent flower in a very large truss; erect in growth; foliage bright green.

Flamingo. Height $3 \frac{1}{2}$ feet ; flowers 4 inches in diameter with almost flat face, forming a spike of glowing crimson color, once seen, not soon to be forgotten; ever-blooming from beginning to end of season.

Souv. d'Antoine Crozy. The very finest of all the gilt-edged varieties to date. Color-dazzliug crimson scarlet, with broad-laced border of bright gold. It is a marvelously profuse bloomer. Height, 3 feet. Strong and free growing.

Austria. Flower of immense size, many of them fully six inches across, the petals are very broad with slightly reflexed edges resembling very closely some of the Orchid family. Plants set out early will before midsummer form clumps with from twenty to thirty strong stems, each stem surmounted by tall spikes of golden yellow flowers standing upright like immense lilies.

\section{HARDY LILIES AND FLOWERING BULBS.}

In their season, between October and January, we offer Auratum, Candidum, Longiflorum, Specjosum Meipomone. Speciosum Rubrum, Speclosum Album and Lillum Harrisll bulbs. Also Hyaclnth, Tul'p, Crocus, Narclssus, Freesia and Chinese Sacred Llly Butbs.

Write for Fall Bulb Circular and Price List. 


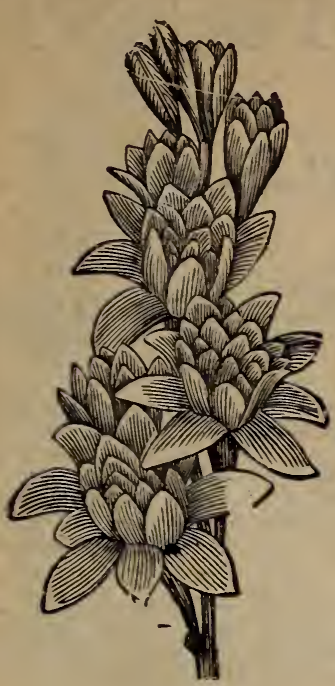

TUBEROSE.

\section{NASTURTIUMS-Tall or Climbing Nasturtiums.}

Beautif ul and luxuriant annual climbers, for trellises and arbors, of easiest culture, bearing their gorgeous flowers in profusion until killed by frost. 6 to 11) feet.

King of the Blacks. Deepest brown.

King Theodore. Velvety dark crimson ; dark foliage.

Tall Rose. Brilliant.

Each of above, pkt. $5 \mathrm{c} ;$ oz. $15 \mathrm{c} ; 4$ oz. $50 \mathrm{c}$.

Mixed. All colors. Pkt. $5 \mathrm{c}$; oz. $10 \mathrm{c} ; 4$ oz. $30 \mathrm{c}$; $1 \mathrm{~b}$. $\$ 1.00$.

\section{DWARF OR TOM THUMB NASTURTIUMS.}

Lady Bird. A new and distinct sort, rich golden yellow, each petal barred with a broad vein of bright ruby crimson ; very showy and charming.

Ruby King. Carmine ; Bronze-Chocolate.

Each of above varieties, pkt $5 \mathrm{c} ; \mathrm{oz} .15 \mathrm{c} ; 4 \mathrm{oz} .50 \mathrm{c}$.

Mixed. All colors. Pkt. $5 \mathrm{c}$; oz. $10 \mathrm{c} ; 4$ oz. $30 \mathrm{c} ; 1 \mathrm{~b} . \$ 1.00$.

\section{SUMMER FLOWERING BULBS.}

Tuberose Bulbs. We have our Tuberose Bulbs grown for us, and can off er you better quality and size bulbs than you can buy elsewhere.

Each. Doz. 100.

Dwarf Pearl Tuberose Bulbs. 4 to 6 inch $\quad 5_{0} \quad 35 \$ 2.00$

Caladium Esculentum. (Elephant Ear). One of the handsomest of the orna. mental leaved plants for a grand bed of foliage in the garden or on the lawn. Good bulbs each 5 to $15 \mathrm{c}$; per dozen $\$ 1.00$ and $\$ 1.50$. If by mail, add $5 \mathrm{c}$. each to piepay postage.

Madeira Vine. Roots. A beautiful climber, with thick, glossy, light green leaves, flowers pure white; rapid grower. Price, $5 c$ each ; $30 \mathrm{c}$. per dozen.

Double Dahlias. Grandest Autumn flower we have. Irarge flowering or show Dahlias of all colors. Roots from 10 c. to $25 \mathrm{c} ; \$ 1.00$ to $\$ 2.00$ per dozen.

Gladiolus. These fine Summer-blooming buibs produce flowers of every shade of color, and some are marvels of beauty. Are easy of culture and their brilliant spikes make one of the most magnificent displays of the flower garden. By planting from May till June. a continuous succession of flowers will be secured.

Gladiolos. Each. Doz. 100.

All colors, mixed .................. 3c $25 \mathrm{c} \quad \$ 1.50$

$U$ hite and light varieties

Striped and variegated varieties, $5 \mathrm{c} \quad 50 \mathrm{c} \quad 3.50$
GLADIOLUS.

Pink varieties, mixed $4 \mathrm{c} \quad 40 \mathrm{c} \quad \$ 2.50$ 3c $30 \mathrm{c} \quad 1.75$ Yellow varieties, mixed ............. $5 \mathrm{c}$ 50 4.00 Lemoine's Butterfly Gladiol., mxd. 4c $40 \mathrm{c} \quad 2.25$

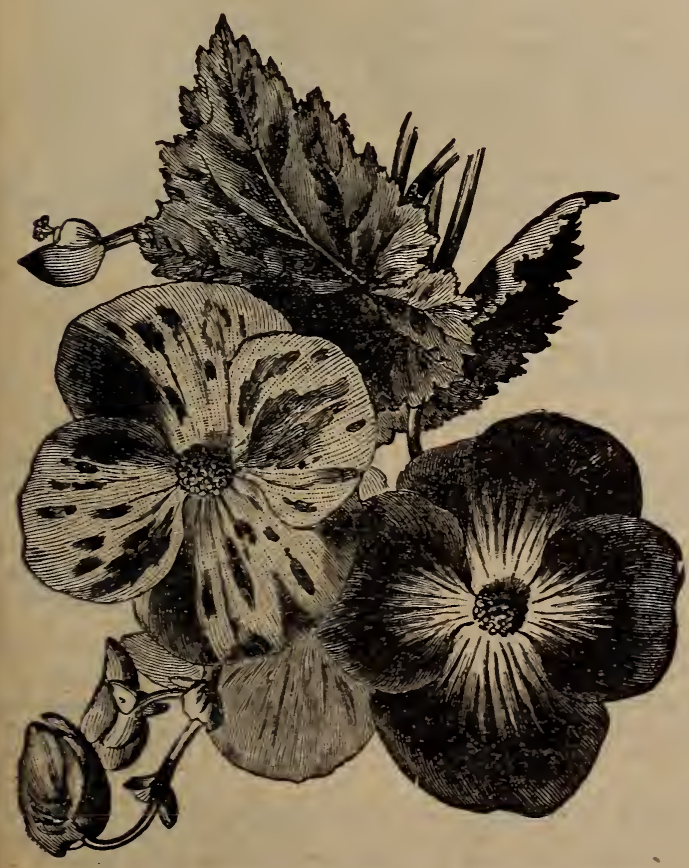

TUBEROUS BEGONIA.

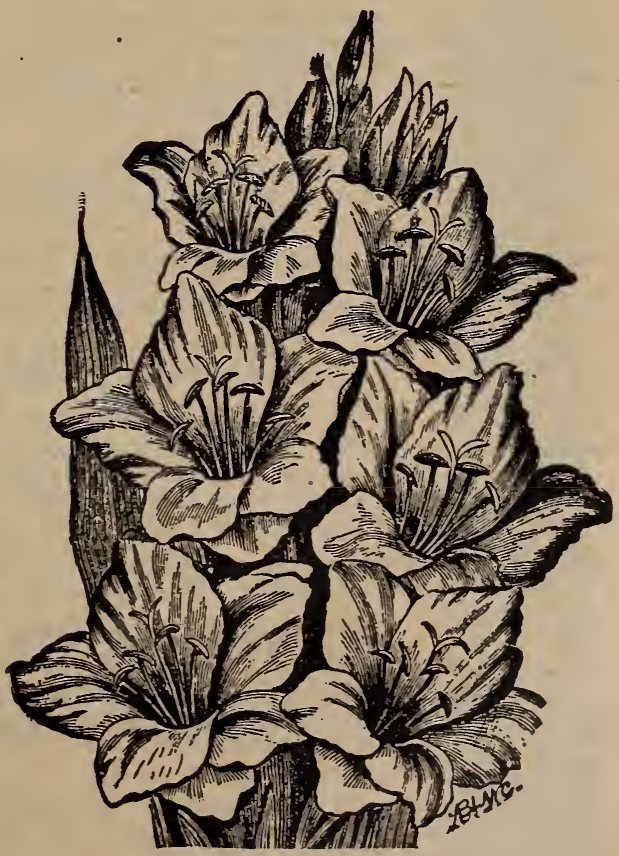

GLADIOLUS.

New Tuberous-Rooted Begonias. These vigorous bulbs are now the most popular plants for beds of Sum. mer flowers, or as pot plants for the greenhouse, conservatory or sitting-room. Nothing can exceed the brilliancy of their colors, the delicacy of their tints, the richness of their waxy flowers, the gorgeousness of the ir effect in masses, or their graceful appearance in beds or borders. From the time the first blossom appears until all growth is stopped by frost, they are never out of bloom. (See cut). We imported these bulbs direct from Paris (France), and they are all sound. well matured and of large size. Price, Single Tuberous Begonias - flnest mixture. large size bulbs-each $5 \mathrm{c}$ : per doz. $50 \mathrm{c}$; per $100, \$ 4.00$. The same in separate colors, viz., Rose, Scarlet, Brilliant Red, Orange and white, at $8 c$. each; $60 c$. per dozen. 


\section{CHOICE SPRING SEED BARLEY.}

(48 lbs. to bushel.)

Quantity of seed sown per acre is about $1 \frac{1}{2}$ to 2 bushels.

NOTE - This crop is receiving more attention in some sections of the country than formerly, and is now considered more probitable than the wheat crop It brings a fair price on the market, and makes excellent feed for stock. The best soil for barley is a light friable loam, but it does well on most clay lands that receive good cultivation and are properly drained.

Ohio Beardless Barley. This beardless Barley is of recent introduction and we know will please our friends. Like other grain, large yields cannot be had each year, but on an averıge immense yields are reported to us Cattle will leave green clover to feed on the straw. It is six rowed and of unusual length of head. Is earliest to ripen, therefore good for all sections. The straw is stiff and will stand up on any soil, and will produce 80 bushels and more to the acre. This is the only Barley fit to feed to stock Every farmer should try it; it can be sown early ; frost will not hurt it; weighs twice what oats does per bushel so worth more to the farmer as a crop. Be sure to try it. Price, peck 4 Uc; bushel $\$ 1.25$ In lots of ten bushels and over, special price.

Manshary Barley is one of the very best six rowed Barley grown; for malting is the very best known: is early in ripening, which helps it to fill well, thus it alweys fills plump; six rowed has a strong upright straw, that make; it easy to hirvest yields from 50 to 80 bushels per acre. Heads of this Barley are very long and contain 75 to 100 heavy kernels of grain. Peck $40 \mathrm{c}$; bushel $\$ 1.25$. Special price for ten bushels and more.

Bcotch Golden Grain Barley. Exceedingly handsome, two rowed, of very plump heavy grain, highly prized for its superior malting quality; very prolific. Always commands a high price. Peck 40c; bushel $\$ 1.2$. In lots of ten bushels and over, special price.

Barloy for Hens. Price per bushel 7ð̌c.

\section{SEED BUCKWHEAT.}

(50 lbs. to bushel.)

Sow from 3 pecks to a bushel to the acre.

NOTE-Buckwheat thrives on comparatively poor land: can be planted so late as to prove a profitable second crop to follow early grass, peas, potatoes, etc. Good to plow under for green manure.

Carly Japanese. Sown at the same time with Silver Hull is about two weeks earlier. The kernels are twice the size of any other Buckwheat, of a rich dark brown color, and manufacture a superior flour. Peck $40 \mathrm{c}$; bushel $\$ 1.25$.

European Silver Hnll Buckwheat. Yields more and produces more flour than the common. Is longer is bloom than the ordinary sort. Husk is very thin, grain is rounder, of a beautiful light gray color. Peck $40 \mathrm{c}$; bushel $\$ 1.25$.

Common Gray. The old well known sort. Peck 30 ; bushel $\$ 1.00$.

For large lots, special prices on application.

\section{IMPROVED BROOM CORN.}

48 1bs. to Bushel.

Sow from 10 to 12 qts per Acre.

Improved Eyergreen. The Improved Evergreen Broom Corn grows about seven to nine feet high, stands up well, and is free from crooked brush its greatest value to growers is the fact that it will noi get red in the field before it is citt, but is strictly a green variety of brush, and will always command highest price. 1,b. $10 \mathrm{c} ; 1 / 2$ peck $35 \mathrm{c}$; peck $60 \mathrm{c}$; bushel $\$ 2.00$. (By mail postage extra 8c. per 1b.)

Farly Dwarf or Mohawk. Grows from three to five feet high and produces short fine brush, suitable for whisk brooms and brushes. Lb. $10 \mathrm{c}$; $1 / 2$ peck $35 \mathrm{c}$; peck $60 \mathrm{c}$; bushel $\$ 2.00$. (By mail postage extra $8 \mathrm{c}$. per $1 \mathrm{~b}$.)

\section{FODDER AND ENSILAGE CORN.}

Good fodder and plenty of it, supplemented by a generous grain ration, is as essential as good cows in profitable dairying, and when well grown and properly cured is far better than average hay. To secure the full nutritive value of Corn Fodder. it should be planted in drills three feet apart, and at the rate of 12 to 10 quarts per acre.

The Celebrated Red Cob Ensilage. A southern tvpe of large white Corn with deep red cob, strong, leafy stalks and short joints. Adapted to all sections of the country, and a general favorite with thousands of dairy farmers we sell to every year. Price, shelled, peck $30 \mathrm{c}$; bushel $\$ 100$; in bag of $2 \%$ bushels, $\$ 2.50$.

\section{SWEET CORN FOR FODDER.}

There is nothing better for green food, or for curin z for winter than Sweet Corn. Cattle highly relish it, and when fed on it keep in fine condition and give an abund ince of milk. It has the great merit of being so sweet and palatable that cattle eat every part of the stalks and leaves, and consequently none is wasted. Farmers in this section should raise more Sweet Corn as feed for young hoss. which is sure to give better results than feeding common field corn Also excellent for solling. Sow thickly in drills or broadcast, at the rate of two or three bushels per acre. Peck $40 \mathrm{c}$; bushel $\$ 1.50$; lower grades $\$ 1.25$ per bushel. 


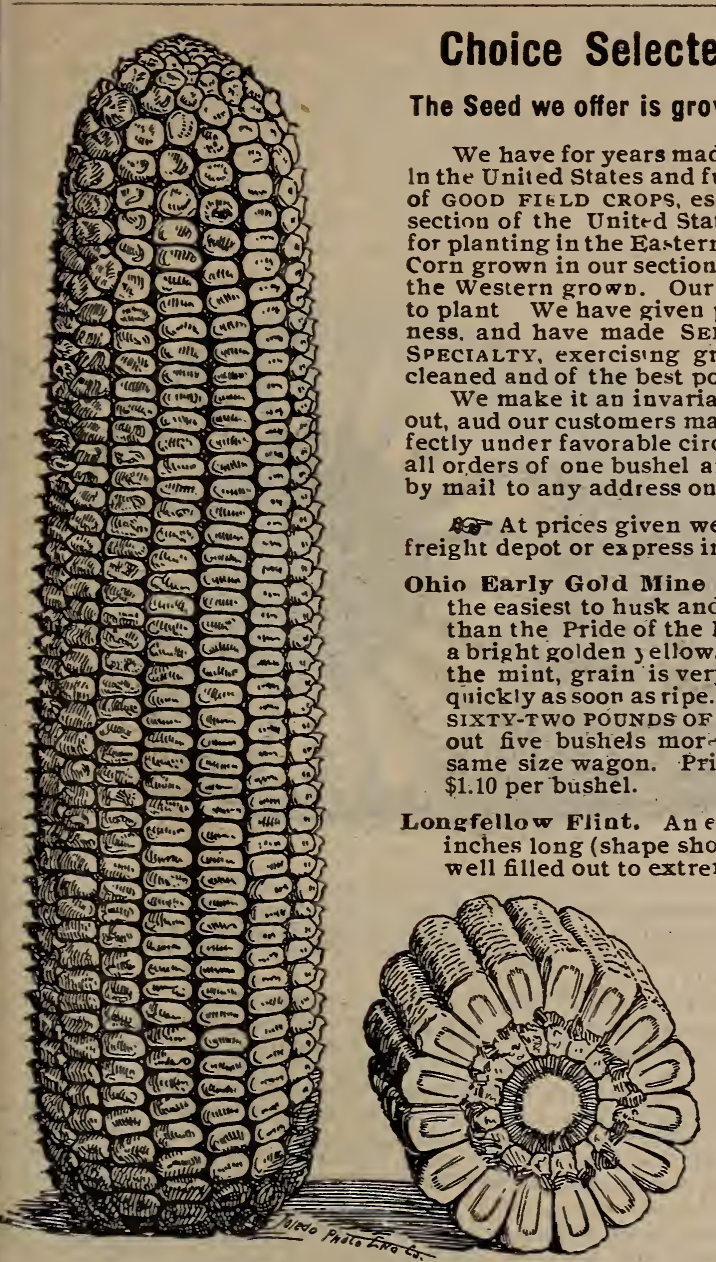

OHIO EARLY GOLD MINE CORN. 10 per bushel.

\title{
Northern Grown Seed Corn.
}

\begin{abstract}
We have for years made a careful study of the best varieties of Corn grown In the United States and fully appreciating the great importance to the Iarmer of GOOD FIELD CROPS, especially seed Corn. we hold that Corn grown in our section of the United States. ju-t at the edge of Michigan, is far preferable

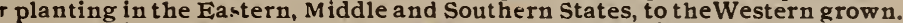
Corn grown in our section will mature sooner and make far better yield than Wiven particular attention to thi s department of our busiTELECTI IN AND IMPROVEMRNT OF FARM SEEDS A cleaned and of the best possible quality.

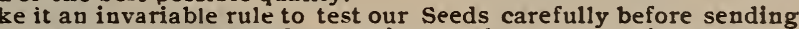
aur customers may depend on getting Seed Corn that will grow per-

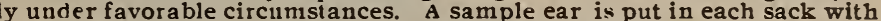
dress on rectipt of twenty cents to cover postage.
\end{abstract}

Tine Corn. Is THE BEST Yellow Corn that grows, also the easiest to husk and shell. It is early, ripering only a few days later than the Pride of the North: ears are of good size and symmetrical color is very deep. cob small, and therefore it dries out very SEVENTY POUNDS OF EAR CORN MARE SIXTY TO

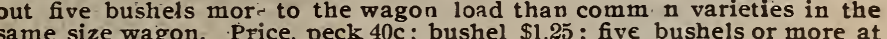
well filled out to extreme end of cob. Cob small, b ernel large and broad, Ear 20c; quart 20c; peck $50 \mathrm{c}$; bushel $\$ 1.25$. Five or more bushels $\$ 110$ per bus,

Thoroughbred Rural Early Lirga White F int Corn. This Large Early White Flint Corn was introduced for the first ime by the RURAL NEW YORKER, and it has proved itself to be the largest eirly Flint corn in cultivation; a wonderful yielder from 3 to 4 ears of 12 to 18 inches on one stalk, strong grower even on light soil. Quart $20 \mathrm{c}$; peck 50c; bushel $\$ 1.50$.

Extra Early King Phillip. (Improved Flint). This excellent red or variegated Flint Corn is so well known that it needs no special description. Quart $20 \mathrm{c}$; peck 50c; bushel $\$ 1.40$.

Champion Early White Pearl. An extra early pure while variety of the Dent family' very productive and exceedingly heavy, maturing in 85 to 90 days from the time of planting. The grain is EXTRA DEEP AND WIDE, two of which will more than span the cob, which is VERY SMALL. Quart $20 \mathrm{c}$; peck $40 \mathrm{c}$; bushel $\$ 1.00$.

Improved Genuine Carly Pride of the North. A very early golden Dent variety, ripening with the Flint sorts, and can be successfully grown further North than any other variety of Dent Corn. Stalks small, with broad leaves. Ears short, 12 to 16 rowed, well filled. Grain long, yellow. Quart $20 \mathrm{c}$; peck $40 \mathrm{c}$; bushel $\$ 1.25$.

Maumee Val ey Extra Early Gilhouse. A hybridized Yellow Dent and Flint corn, a beautiful light yellow, kernels $2 / 3$ of an inch broad, 8 rowed, grows of medium height, enormous yielder, 2 to 4 good sized ears on stalk, the earliest of all the corn, will make a crop and ripen if planted as late as July 1st. The finest kind for meal and stock. By mail, ear 20 c ; quart 30 c. By express, peck 50 c; bushel $\$ 1.50$.

New White Cap Farly Yellow Dent Corn. This new Corn has shown more fine and lasting points than any corn in cultivation. It has more solid merit than the Leaming Corn, for it grows larger ears and is a better sheller and from a week to ten days earlier, and on poor, thin soil will out-yield the Leaming by at least 30 per cent. The tip ends of the grain are white, the inside yellow, making it a beautiful color, both on the cob and when shelled. Expert corn growers pronounce it a perfect field corn, as to yield, size of ears, color, size of cob and growth of fodder. More genuine testimonials can be procured in its favor than all other sorts combined. No corn in the world will yield as well on poor, thin land, and none stands the drouth as well. While on strong, rich land its yield is wonderful. Many of our customers reported to us immense yields, from 100 to 150 bushels per acre, and this on thin land and hardly any rain.

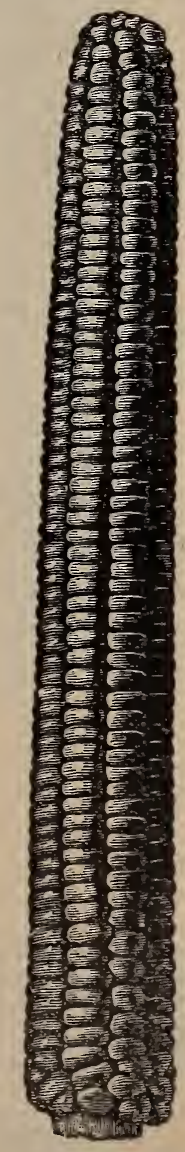

LONGFELLOW CORN. 
Large growers in the great corn belt, as well as those out of it, will be pleased with this Corn. Because, 1 st-It is as natural a yielder as weeds. 2nd-It will yield large crops on poor, thin soil. 3rd-The ears are large, handsome and well filled. 4 th-It is sure to mature in 85 to 95 days. 5 th-It husks easy and shells easy. 6th-It commands the highest market prices. 7th-It will grow more bushels on poor, thin land than any other kind in the world. 8 th-Stands the drouth better than 60 other kinds grown in the same county. $9 \mathrm{th}-\mathrm{It}$ has small cob and large number of rows on cob, making a wonderful yielder. $10 \mathrm{th}$-It will out-shell and out-yield the Leaming Corn. 11th-It grows its fodder strong. 12th-It combines more genuine merit for all soils and climates than any corn in cultivation. 13th-It is sure to please all who give it a trial. We highly recommend. this Corn to our friends, and hope they will give it a trial. Price per peck $40 \mathrm{c}$; bushel $\$ 1.10$. In five bushel and. upward lots, $\$ 1.00$ per bushel.

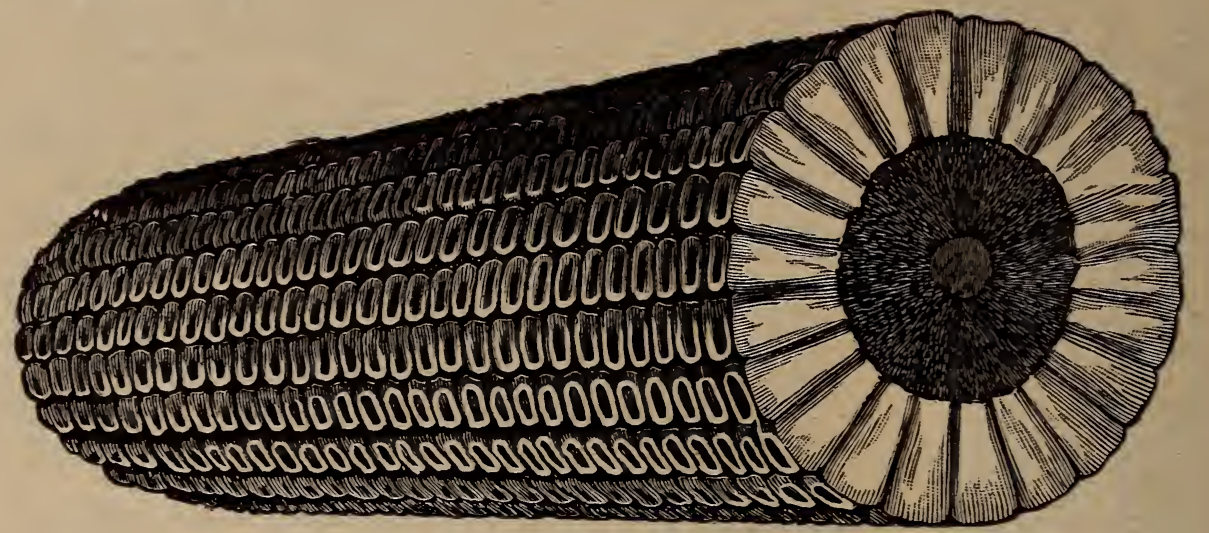

IMPROVED LEAMING CORN.

Improved Leaming Corn. The true Improved Leaming Gorn is a pure, fixed and distinct variety. It is not a hard, flinty corn. but sweet and nutritious, making excellent feed and the finest meal, its quality not being surpassed by any other known variety. The ears are large and handsome. with very large deep grain of deep orange color and red cob. Produces two good ears to each stalk and husks and shells easily; good producer. Price, quart $20 \mathrm{c}$; peck $40 \mathrm{c}$; bushel $\$ 1.10$;

The Clarage Early Yellow Dent Corn. This is an Early Yellow Dent Corn, and suitable, if necessary, for late planting. The Ohio State Board of Agriculture grew it on the grouvds of the State Experimental Farm, and gave it in their report the highest recommend of all the early varieties of Yellow Dent.Corn, in earliness, the number of bushels to the acre, average ears to each stalk, size of ears and least per cent of nubs. It is of good bright color, ear very even in size its entire length and kernels set square in rows; 14 to 18 rowed; it is a week earlier than any other Dent Corn, and large ears. We introduced this valuable variety of corn years ago, and must say that we never sold Seed Corn which gave such universal satisfaction, and have received many flattering testimonials. Several farmers have sold their crops of hundreds of bushels at double the price of corn, to their neighbors and dealers in other parts of the country. Quart $20 \mathrm{c}$; peck $40 \mathrm{c}$; bushel $\$ 1.10$.

Extra Carly Huron Dent Corn. After a trial on a large scale, we bave concluded that this is the earliest Dent Corn grown. Good size stalk and ear, small red cob, long deep grain, very rich in oil and starch, and is the only smooth very early Dent Corn known. Ears wonderfully perfect, grained even on both ends of cob, has quick, rank, strong growth, and is very productive; it heads the list of all extra early varieties. Our cupply is genuine and from the originator's stock, strictly pure and carefully selected. Quart 20c: peck 40c: bushel \$1.10.

We are recleaners of all kinds of field seeds, having power cleaners operated by electric motor, and an therefore glve you better and more even grades of field seeds than you will buy elsewhere. Commission houses do not, in all cases, reclean the seed they ship out, so it will pay you to order of us and get seed that is all of one grade. Give us a trial.

\title{
FLAX SEED.
}

( 56 1bs, to bushel.)

Flax. Dakota. Extra cleaned. Lb. $6 \mathrm{c} ; 1 / 2$ peck $25 \mathrm{c}$; peck $50 \mathrm{c}$; bushel $\$ 1.75$.

\section{CHOICE, SELECTED SEED OATS.}

\author{
NORTHERN GROWN CHOTCE SEED.
}

We are not great bellevers in fancy Oats at extravagant prices, but we do believe an occasional change of seed is a paying investment, and that new hybrids have been introduced of great value. The stock we of er was especially grown for us for seed, and carefully recleaned by us, and who would not grow pure, reliable, choice, improved heavy oats, in preference to the light mixed and chaffy kinds, that only yield half a crop of inferior quality.

New White superior Scotoh Oate. In limited amounts only. The heaviest Oats ever introduced in the U. S. Very often weigh $50 \mathrm{lbs}$. to the measured bushel. They surpass all ther White Oats in heavy weight, thin hull, shortness and plumpness of grain Their stroug straw adapts them to rich bottom ground where common Oats will fall down and waste, and are enormously productive, some reports being as high as 152 bushels per acre. We therefore recommend all progressive agriculturists to give them a trial and make Oats a paying crop. Price, peck $25 \mathrm{c}$; bushel $85 \mathrm{c} ; 5$ bushels and upwards $75 c$ per bushel. 


\section{THE IMPROVED}

\section{AMERICAN BANNER OATS $\sim \leadsto 1901$ CROP.«}

We offer you caref ully grown Seed, raised entirely from selected stock. The result of this care in selection is show $\mathrm{n}$ in the crop, which is the finest ever grown, and averaging upwards of 80 bushels to the acre. So that the seed now offered as The Improved Banner Oat is the very best, and every fone should renew their stock at once.

This wonderful grain stands the tests even in the driest seasons, and to-day, after hundreds of trials in all parts of the country, its fame is higher and more secure than ever before. Reports from all sections indicate a satisfaction that is truly, gratifying, but not more than was expected when it was first sent out. For it had been very thoroughly tried and proved to be the MOST PROLIFIC VARIETY OF OATS ON RECORD. One hundred bushels to the acre has been raised, and that certainly ought to satisfy the most exacting. On fields to which no fertilizer has been applied for two years, 70 bushels to the acre have been produced. This year all that has been claimed for it has again been realized, and so it stands to-day as the Improved Banner Oats of America. An average of eighty pounds has been raised from a single pound of seed-thirty pounds in excess of what was claimed for it when first introduced.

The grain is white, large and plump, ripens early, has a stiff straw of good length. It tetters freely and throws up a large number of stems, and therefore can be sown thinner than ordinary Oats. It is as near rust proof as any Oats can be. Every one who raises Oats should try the variety. An Oat that will yield 60 to 80 bushels to the acre with ordinary culture is good enough to raise and good enough for everybody to make a trial of. On good soil and with good weather it will go far a head.

Prices, postpaid, per pound $20 \mathrm{c} ; 3$ pounds $40 \mathrm{c}$. By express or freight, at expense of purchaser. Per peck $25 \mathrm{c}$, per bushel $85 \mathrm{c}, 10$ bushel lots $75 \mathrm{c}$ per bushel. For larger quantities, special prices on application.

Improved Black Tartarian. These Oats were grown specially for seed from pure imported stock from Europe, which we have grown in sufficient quantity to offer this year, so that our customers can have a chance to try its merits. The grain is very large, shiny, plump and full, very thin hull, and it is exceedingly prolific, having yielded at the rate of 100 bushels to the acre with only ordinary cultivation, and has proved absolutely RUST PROOF where other varieties were destroyed by rust; weighing 48 pounds to the measured bushel. Peck 25c per bushel 85c, 10 bushels and over 75c a bushel. Irarger lots special price. Samples mailed on application.

The Famous Lincoln Oats. We have had grown for us a very fine stock of these New Lincoln White Oats, introduced in the Western States with such grand results as to its wonderful productiveness, some reporting as high as 174 bushels from a single bushel of seed sown; claimed to have a remarkably stiff straw, standing up well on all kinds of soil; very early, and so far proven entirely rust proof; it is very valuable for seeding on account of its thin hull, heavy meat and soft nib. From what reports we have we think these oats ought to be grown by every progressive agriculturist, especially when the price we offer them is so reasonable. Price, peck, 25c; per bushel, $85 \mathrm{c}$; 10 bushels and over, $75 \mathrm{c}$ a bushel; large lots, special price.

Full weight and full size cotton bags for Barley and Oats, $16 \mathrm{ceach}$.

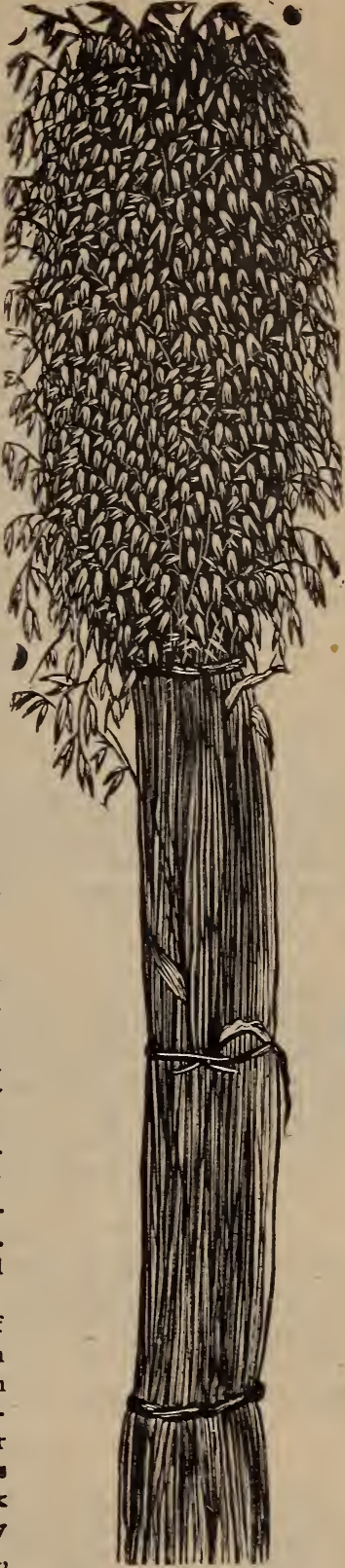

THE IMPROVED AMERICAK BANNER OAT.

\section{NHW SHIJSATIONT WIITH OATS.}

These Oats are of our own raising and are about ten days earlier than common oats. With short stiff straw that will not lodge or rust.

The grain is very heavy, an immense yielder, and an all-round good oat.

Peck -

Bushel,

Ten Bushels and Over
25 cents.

85 “

75 " per bushel. 


\section{CANADA FIELD AND COW PEAS. \\ Cotton Bags 16 cents. \\ Price Subject to Market.}

White and Blue Varieties. They are used mostly for field culture In their dry state they are used extenwively for feeding pigeons, making soups, also table use; in their green state for turning in hogs.

Canada Field Peas. From one to two bushels, according to soil, are sufficient to sow per acre. Bushel $\$ 50$, peck $35 c$, quart $10 c$, pint $5 c$. Special price on 10 bushels or over.

Cow Peas, (Whip-porr-Will). and Other Varieties. The best for soiling. Broadcast, $11 / 2$ bushel per acre. Nothing better for stock of all kinds, green or dry state. Quart 15c, bushel $\$ 2.00$. Special prices for 10 bushels and larger orders.

We sell car loads every season, and are headquarters for FIELD PEAs.

\section{RAPE SEED.}

(Sow 6 lbs. per acre.)

True Dwarf Essex English Rape Seed. Mr. Owen, of Norwalk, a customer of ours, seedcd $3 / 4$ of an acre to Rape and pastured 60 hogs on it all season, and they grew fat. The hogs had access to this field at will, and at the end of the season the patch was still green. Think this over carefully and try it. Millions of acres of good land that annually lie idle or run to weeds in this country in the latter part of the season, after the grain, potato and hay crops have been harvested, might be made to produce one of the finest feeds imaginable, and in the greatest abundance, at a time when cattle and sheep are roaming through the pastures in search of a scanty living Rape may be sown broadcast at the rate of six pounds per acre and harrowed in, or the land may be thoroughly harrowed and the seed sown in drills. Under favorable conditions it is ready for pasturing pigs, sheep and cattle within six weeks from the time of sowing, and on an average one acre will carry $t$ welve to fifteen sheep six weeks to two months. There are several varieties of Rape, but care should be taken to procure the genuine Dwarf Essex, which does not seed the same season as sown, and seed is larger than the common Rape and Mustard Seed usually used and sold for bird seed Rape Seed can be sown and cultivated in the growing corn. Price, 1b. $10 \mathrm{c} ; \$ 0.00$ per 100 lbs. Cotton bags, $16 \mathrm{c}$

\section{RYE.}

(Sow from 1 to $1 \frac{1}{2}$ bushel per acre.)

Very little attention has been paid to fertilizing this crop until lately, but recent experiments have shown that it pays as well to feed the Rye crop liberally as almost any other. It is a good crop to grow for greer manuring. We know of some farmers on clay lands who grow corn every year and keep up the fertility of the soll by using fertilizers and rye as as a catch crop, which turned under in the Spring keeps plenty of humus in the soil and the land improving all the time.,

Mammoth White Rye. For Fall seeding. Per peck 30c; bushel $\$ 1.00$.

SPELTZ.

Introduced from Germany into this country several years ago, and from al! reports will grow anywhere in the United States, and we can safely offer the seed to our customers as one of the grandest fodder crops grown. Speltz is an immense yielder and for fattening cattle and hogs has no equal, being better food than cora. Speltz should be sown early in the Spring, the same as Spring Barley and spring Wheat, at the rate of from 75 to $100 \mathrm{lbs}$. per acre, and enormous yields a re assured. We offer Ohio grown seed at the following rates delivered f. 0 . b. cars or Express here. Cotton bags extra 16 cents each. Pouud, post paid, 20 cents. By freight, 50 lbs. $\$ 2.00 ; 100 \mathrm{lbs} \$ 3.50$.

\section{SUGAR CANE SEED, SORGHUM, ETC.}

Drill, 4 to 6 lbs. per acre ; broadcast, 10 to 12 lbs.

Early Amber. This is a standard variety now being successfully grown even in the extreme northern latitudes. It may be planted as late as the 15 th of June, and will be ripe enough to inanufacture in September. It is the earliest variety with which we are acquainted. The beautiful a mber-colored sy rup it produces is thought to be superior in flavor to any other, and for sugar is unsurpassed. It is useless to plant Cane Seed before the weather is warm in Spring. Our stock is choice. Price, 10c. per 1b.; $10 \mathrm{lbs}$. $65 \mathrm{c} ; 50$ to 100 lbs. 5c. $1 \mathrm{~b}$.

Early Orange. Another favorite sort. Price, 10c. per 1b. ; $10 \mathrm{lbs} .65 \mathrm{c} ; 50$ to $100 \mathrm{lbs}$. Ec. 1b.

\section{Sorghum or Sugar Cane for Stock Fodder.}

Sow different times up to July 15 , at the rate of $20 \mathrm{lbs}$. peracre. Dairymen, and in fact every farmer, should grow it for horses, cattle and hogs, as they eagerly eat and relish it, a nd nothing pays better. Dairymen es pecially should grow this sugar cane seed, as it gives them the best green fodder just iu time when pisture is dried up. and will produce more and better milk than any other forage plant, even clover. $8 \mathrm{c}$, per $1 \mathrm{~b}, ; 10 \mathrm{lbs}$. $50 \mathrm{c} ; 20$ 1bs. $90 \mathrm{c}$; 50 to $100 \mathrm{lbs}$. $4 \mathrm{c}$. per $1 \mathrm{~b}$.

\section{Non-Saccharine Sorghums.}

These varieties bear warm weather well. They grow on any land where corn will, even on land too poor for corn. It takes from five to six pounds to plant one acre.

Kaffir Corn or Sorghum. Kaffir corn is now successfully cultivated for both forage and grain in all sections of the United States It is the best general purpose plant of all the varieties of Sorghum vet offered, unless it be the new Jerusalem corn, and will make a paying crop on land that will not yield ive bushels of Corn or Wheat. It is early as Amber Cane. It will make a fine crop of forage if cut in early bloom, and the shoots that then follow will make a good second crop to feed green or dry for winter. Per $1 \mathrm{~b} .10 \mathrm{c} ; 10 \mathrm{lbs}$. $40 \mathrm{c}$; $20 \mathrm{ltss} .60 \mathrm{c}$; 50 to $100 \mathrm{lbs} .21 / 2 \mathrm{c}$. per $1 \mathrm{~b}$.

The Jerasalem Corn. A new forage and grain plant introduced in this country a few years ago, and the $\mathrm{O} S$ experimental stations recommend it very highly. Pkt. $10 \mathrm{c}$; 1b. 20c; postpaid. Per express or freight. $10 \mathrm{lbs} .60 \mathrm{c} ; 20 \mathrm{lbs}$. $\$ 1.00$. 


\section{SUNFLOWER-MAMMOTH RUSSIAN.}

CULTURE.-The Sunflower, during the past few years, has attracted considerable attention as a profitable field crop, its leaves being used for forage and its seed for poultry and the manufacture of oil. It is also planted with satisfactory results on low, swampy ground, to avoid mlasma.

Mammoth Russian. Striped seed. Price per $1 \mathrm{~b} .10 \mathrm{c} ; 50 \mathrm{lbs}$. and upwards $6 \mathrm{c}$. per $1 \mathrm{~b}$. This is one of the best egg-producing foods known for poultry, keeping them in fine condition. Cotton bags, 16c.

\section{TOBACCO SEED.}

Connecticut Seed Leaf. Best adapted to the climate of the Middle and Northern States, as it is more hardy and endures the cold better than the tender varieties. Pkt. 10c, ounce 50c.

Ohio Seed Leaf. Pkt. 10c, ounce 50c.

Imported Havana, Pure Cuban grown seed, and when grown in this country commands a high price for cigar stock. Pkt, 10c, ounce 75c.

When wanted, we can furnish other varieties at low prices.

\section{VETCHES OR TARES.}

Vetches or Tares are grown for a forage crop. Sow two bushels per acre.

The Hairy or Sand Vetch. (VICra Villosa): Short crop and high this year. This has proved to be the most valuable of all vetches. It succeeds on all soils and does not suffer from extreme drouth, heat or cold. Sown in Spring or Fall. it quickly produces a most luxuriant growth. From tests made by Ohio's Department of Agriculture, the Hairy or Sand Vetches do well and will remain green throughout all but the most severe winter weather. Try it. Sow 40 to 50 pounds per acre. Price, 15c 1b. not postpaid; $\$ 12.00$ per 100 lbs. by freight or express.

\section{SEED WHEAT.}

NOTE.-No matter how low prices may go, wheat will continue to be grown, for there is nothing else that will take its place in many crop rotations, especially where grass is to follow. It makes a sale crop, and the straw is indispensable about the barn if stock is to be kept comfortable and in a thriving condition. It has been found that wheat can be fed to stock very profitably when the price is toolow to send it to market, and, alta. gether, the consumption of wheat is likely to increase rather than diminish in the near future. In view of these facts, farmers should learn how to grow the crop cheaper, or in other words, how to increase the a verage yield per acre, for there is a profit when between thirty and forty bushels are obtained. There is no doubt of most farmers being able to obtain such a yield if thorough cultivation and fertilization are employed.

North Dakota Fife Spring Wheat. Peck 50c, bushel $\$ 1.50$.

We will have all the leading and new varietles of northern grown Winter Wheat, of which we will issue a Special Seed Wheat Catalogue, containing full descriptions and prices, by July 20th next, and malled free to all applicants. Our customers should write for this list.

We name the following varieties that we offer at $\$ 1.25$ per bushel in small lots. Special price on ten'bushel lots and over :

\section{SMOOTH VARIETIES.}

POOL,

FULTZ,

RED CLA WSON,

NUMBER SIX,

DIAMOND GRIT.

HYBRID MEDITERANEAN.

Please bear in mind that we are Re-cleaners of all kinds of Field Seeds and you get nothing but thoroughly Re-cleaned Seed if you order of us. 


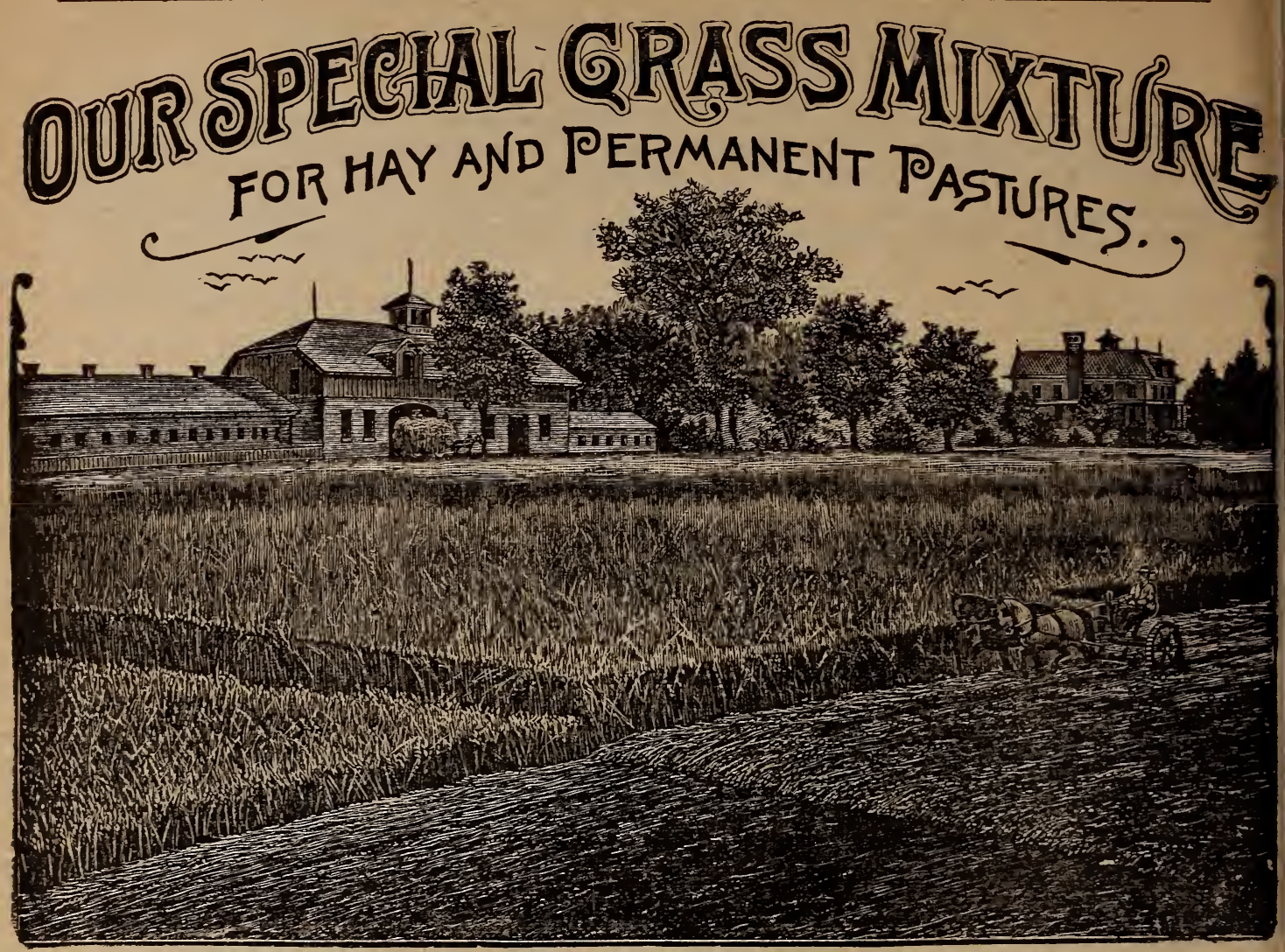

NO PHOSPHATE USED.

PIONEER MAUMEE VALLEY PHOSPHATE USEB.

One thing is certain that good pasture land is the foundation of the riches of a farm.

\section{Grass Mixtures for Permanent Pastures.}

The past years have demonstrated the necessity of devoting more attention to good pastures. Most of the farmers have not yet learned that a pasture or Meadow of Mixed Grasses is far superior to Clover and Timothy alone, but such is the case.

There is an increasing demand for grass seeds for remaining down for two or more years, and in the present depressed condition of agriculture, the system of extending the period during which rotation grasses remain down has many advantages, while the cost of suitable seeds is much less than those for permanent pasture.

No.1. Grass Mixture for Permanent Pasture.-The base of this special mixture is ORCHARD Grass. which yields as abundant crops as the ordinary mixture of "Timothy and Red Top," and is also A MUCH MORE PERMANENT GRASS than Timothy; with the great luxuriance of its aftermath, it possesses remarkable powers of enduring the cropping of cattle. Besides Orchard Grass, this mixture is made up of OUR NORTHERN RED TOP (which grows taller and makes better hay than the Red Top from the South) and English Rye Grass, Tall weadow Oat Grass, English Blue Grass, Kentucky Blue Grass and Alsike Clover Seed, which gives permanency to the sward. From 25 to 35 pounds should be sown to the acre. This mixture is good on any soil. Per $1 \mathrm{~b}$. $18 \mathrm{c}$; per 100 lbs. $\$ 14.00$.

No. 2. For Mowing and Grazing In Orchards and Shaded Situations. - English Rye Grass, Timothy, Meadow Foxtail Grass, Orchard Grass, Wood Meadow Grass, Italian Rye Grass, Tall Meadow Oat Grass, Mammoth Clover, Red Top Grass and White Clover. Allowing 20 ibs. per acre. Per 1b. 15c; per $100 \mathrm{lbs}$. $\$ 12.00$.

No. 3. For Pastures on any Solls. - Timothy, Meadow Fescue or English Blue Grass, Meadow Foxtail Grass, Red Top Grass, Orchard Grass, Kentucky Blue Grass, Lucerne Clover, Alsike Clover, White Clover. Allowing 20 lbs. per acre. Per 1 b. $18 \mathrm{c}$; per $100 \mathrm{lbs} . \$ 15.00$.

No. 4. For Ordinary Pasture.-Orchard Grass. Kentucky Blue Grass, Timothy. Red Top, Red and Alsike Clover Seed. Allowing 25 pounds per acre. $12 \mathrm{c}$. per $1 \mathrm{~b} . ; \$ 10.00$ per $100 \mathrm{lbs}$.

No 5. For Wood and New Ground Pasture.-We have a mixture of the following grasses, which we offer at such price that any one who has any room and need for same will no doubt avail themselves of our very low offer. Orchard Grass, Blue Grass, Red Top Grass, Timothy, low grade Alsike and other Clovers. Allowing 30 pounds per acre. 8c. per $1 \mathrm{~b} . ; \$ 7.00$ per $100 \mathrm{lbs}$. 


\section{CHOICE GRASS SEEDS, 1901 CROP.}

Cotton bags extra 16 cents each.

Prices given below for the Field Varieties are for the present only, as the market changes daily.

The growing of Farm Seed is one of our great specialties. Our central location and more even and temperate climate is especially adapted for growing Seeds of all kinds.

Toledo, Ohio, is the greatest Clover Seed market in the world, and we are right in the seed belt. Our Pioneer Brand Medium and Choice Mammoth Clover Seed are the purest and best cleaned of all. Our large mail order trade has been built up by honorable dealing, handling the best grades, and giving our customers just what they pay for and expect to get. We have pleased thousands, according to their friendly testimonials, and will please any one who will favor us with their order, and ask you to be friendly and write us for samples and prices whenever wanting to buy in large or small quantities.

\section{High Grade Extra Clean Clover, Timothy and Other Grass Seeds.}

We pay particular attention to this part of our business. These Seeds are selected and tested with special reference to their quality. Purchasers may rely upon our best exertions to furnish Grass and Field Seeds pure and free from noxious and foreign seeds. We grow and buy our stock of growers, and keep in stock large quantities of Clover Seed and other Grass Seeds, cleaned by the most improved electric machinery. Our Clover Seed, Medium and Mammoth, is kept separate and not mixed, as is generally the case of most all seed sold and bought on the Exchage and of commission and export Seed houses Our prices are as low as any reliable seedman can sell such Clover and Grass Seeds for. Of course we do not pretend to compete with the Exchange and commission house prlces, where good and indifferent seeds are mixed and sold at low prices. It is better every time to pay a little more and get the genuine unmixed and clean seed. . Clover is the foundation of all farming. It would even pay the farmer if he had to give $\$ 10$ per bushel for it. We are in position to save you money every time on Grass and Clover Seed. Send us your order, or apply for prices, pamphlets and samples.

Kentncky Blue Grass, English Rye Grass, Orchard Grass and Red Top, in lots of five bushels and over. No CHARGE FOR BAGS. For all other seeds, cotton bags extra. Your orders are solicited and will receive prompt and careful attention, and will be filled at the lowest market price on receipt of same, unless prices are agreed upon before.

Alsike Clover. Swedish Clover (Trifolium Hybridum). So called from being intermediate in its appearance between the Red and White Clovers, possessing qualities common to both, being productive, sweet and permanent. Is valuable for pasturage or soiling; makes the finest hay sown with or without Timothy. The flowers are a distinct light pink and afford fine pasturage for bees. Sow 8 pounds per acre. Pound, postage paid, 25c; per bushel, market price.

The crop of Alsike Clover was a short one again this year and seed not of finest quality. This seed has in former years been mostly sold for export, but there is a growing demand for same in this country, as it makes one of the best forage and hay crops and great yield in seed.

Lucerne or Alfalfa Clover. (Medicago Sativa). Alfalfa is a wonderful forage, fertilizer and hay plant; the greatest cropper of all Clover and Grass varieties; will produce three to four crops in the season; will thrive and grow on dry, barren, sandy, gravelly and hilly land, where no other plants live. The Alfalfa sprout sinks its roots deeply after moist ure and nourishment, and the severest drouth has no effect on it the barren soil keeps covered with a beautiful green crop; also stands wet, heavy rains, deep snows and cold winters. Nothing better to renew old worn out land. The crop is a short one this year. Is now grown successfully in Ohio, and we have Ohio grown seed to offer. Seed can be sown with any grain crop in Spring, or as a separate crop, of 12 to 15 pounds to acre. Pound $15 \mathrm{c}$; postpaid 25c. Market price in quantity.

Bokhara Clover. Honey plant (Melilotus Alba). Excellent for bee food; growing well on poor soil. By mail postpaid, 30c. per pound. Market price for quantity.

Crimson or Scarlet Clover. (Trifolium Incarnatum). Is an annual variety in common use in Italy, France and of late in this country. The best time for sowing is in the early fall. It is a rapid grower: the yield is immense, and for feeding green, late in the Fall and early Spring, it has no equal. Sown also in the months of April and May, for hay, pasture, and as a fertilizer, with excellent results. Crop this year a short one, with prospect of higher prices. As an improver of the soil, or for an early Summer forage or hay crop it is unsurpassed. As a green manuring crop for grain, fruit or trucking crops it gives the very best results, while for improving poor land it has no equal: It succeeds on nearly every kind of soil, and is now grown largely in all the middle States, and has succeeded in every State in the Union where tried. Sow 20 pounds to the acre. Pound $10 \mathrm{c}$; postpaid, $20 \mathrm{c}$; bushel of 60 pounds $\$ 5.00$.

Red Clover. (Trifolium Pratense). This is the common Red Clover, the seed of which is the Clover Seed of commerce. At lowest market price.

Red Clover was largely damaged by extreme dry and hot weather also rains this year, therefore the seed is not of so bright and dark green a color. The brown and red seed our samples contain is off color, but will grow, and barring color is as good for seed as the blue seed.

Mammoth Sapling Clover, English Clover. Compared with the common Red Clover, its flower, foliage and stenis are of darker color. Is valuable when grown with other grasses for mixed hay, as it ripens later than common Red Clover, about the time Timothy, Orchard and other grasses ripen, thereby making the hay a much better quality. Being a very rank grower, it is coming into general use for soiling purposes. Market price.

White Dutch Clover. (Trifolium Repens). Grows naturally in pastures in a great variety of soils and situations, and is an indispensable requisite in all parks and lawns. Pound $25 \mathrm{c}$; post paid $35 \mathrm{c}$. Market price in quantity.

Timothy. (Phleum Pratense). This well known variety is extensively known throughout the country. It will produce a large crop. Sow from 10 to 15 pounds per acre. Bushel 45 pounds. Lowest market price.

Bromus Inermis. The greatest grass grown for dry soils and times. This is a perennial nutritious grass for both hay and pasture, and has had a large sale the last two years. Will grow on most any soils. Sow $281 \mathrm{bs}$. per acre. Price postpaid 20c. per pound. By freight or express $\$ 15.00$ per $100 \mathrm{lbs}$. Bushel weighs $141 \mathrm{bs}$.

Sainfoin. (Ono brychis Sativa). A valuable fodder. Plant on light, dry sandy soil. $201 \mathrm{bs} . \$ 2.00 ; 1 \mathrm{~b} .20 \mathrm{c}$.

Hungarian Grass. A valuable forage grass and hay, both because of its foliage and nutritious seeds; early resists drouth; does well on light soil. Sow one bushel per acre. Bushel 48 pounds. Lowest market price

Common Millet. An excellent early forage grass, with long, broad leaves and nutritious grain. Grows to height of three or four feet. Very early. One bushel per acre. Bushel 50 pounds. Lowest market price.

Improved German or Golden Wonder Millet. This is not so early as the common Millet, but yields much larger crop. Southern grown seed is preferred, producing more hay. Northern grown seed is usually hybridized with other millets and will not grow as tall. Southern grown seed at lowest market price.

The Russian Forage, or Now Manitoba Millet, This is largely grown in Russia, British Columbia and the Dakotas, and introduced by us four years ago. Lowest market price. 
Sweet Vernal, True Perennial. (Anthoxanthum Ordoratum). Very fragrant, especially when bruised. For pasture, mixed with other grasses, is quite valuable as it starts early in Spring and grows until late in Fall By mail, pound $85 \mathrm{c}$.

English Perennial Kye Grass. (Lolium Perenne). A nutritious permanent grass for meadows and pastures; also for mixing with other grasses for lawns Pound $10 \mathrm{c}$; bushel, 24 pounds, $\$ 20$.

Tall Meadow Oat Grass (Avena Elatior). A valuable grass for permanent pasture on account of its early luxuriant growth. Makes splendid hay. Pound $20 \mathrm{c}$; bushel, 13 pounds, $\$ 2,50$.

Italian Rye Grass. (Lolium Italicum). Recommended for permanent pasture mixture. Pound 10c; bushel, 20 pounds, $\$ 1.50$.

Wood Meadow Grass (Poa Nemoralisj. Adapted for pleasure grounds under trees; fine for pasture under close feeding. Sow 28 pounds to acre. Pound, 5 )c; bushel, 14 pounds, $\$ 350$.

Meadow Foxtail. Rough Stalked Meadow. Each, per 1b., 30c; $10 \mathrm{lbs}$. and over, 25c per $1 \mathrm{~b}$.

Hard Fescuc, Sheep Fescue, Meadow Soft. Each, per lb., 20c; $10 \mathrm{lbs}$. and over, 15c per lb.

Kentucky Blue Grass (Poa Pratensis). Kentucky (not Canada) Blue Grass crop was an average one this season. Io very valuable and exceedingly popular in some sections of the country as a pasture grass. It is very productive and unusually early in Spring, furnishing delicious food throughout the season for all kinds of stock. It is not easily effected by drought or frost, is suited to any variety of soils, succeeding best on a moist, rich meadow. For permanent pasture it is particularly valuable, being of dwarf growth; therefore

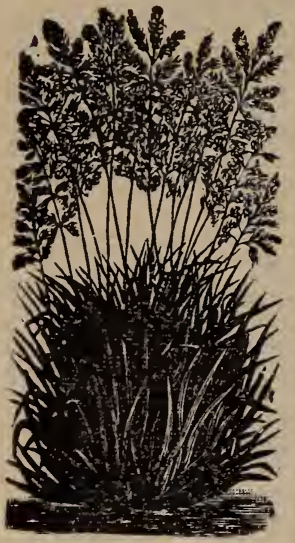

KENTUCKY BLUE GRASS not so well suited for meadows. Unexcelled for lawns. If let grow up in $\mathrm{Fa} 11$ without grazing, makes good $\mathrm{n}$ inter pasture. Our seed is all new crop, Kent ucky' grown and the best grade, "Fancy Cleaned." Beware of the Canada blue grass, which does not make as good pasture as the Kentucky, and the seed contains a considerable proportion of Canadian thistle, which would be a great damage to any farmer, but can be purchased at about half price. We understand that even some Kentucky dealers buy this and sell it as Kentucky grown seed. Sow 28 pounds per acre for pasture and 40 to 50 pounds for lawns. Extra choice. Bushel $\$ 1.25$; peck $40 \mathrm{c}$; pound by mail 20c. Fancy : bushel $\$ 1.50$; peck $60 \mathrm{c}$; pound by mail 25c For larger orders, special price. We can furnish a lower grade (extra clean) Kentucky Blue Grass at $\$ 1.00$ a bushel, but there is but little vitality left in it, and we do not recommend it.

Meadow Fescue (Festuea Pratensis). English Blue Grass. A highly valuable species for permanent grass land. It does not, however, attain its full productive power till the second year, when it far exceeds most other sorts in quantity of its produce and nutritive matter. It is relished by live stock, bot $h$ in hay and pasture, and is one of the most desirable permanent grasses for general culture and mixtures for permanent pasture. Twenty to thirty pounds per acre. Per $100 \mathrm{lbs}$. $\$ 18.00$; per $1 \mathrm{~b} .30 \mathrm{c}$.

Orchard Grass:(Dactylis Glomerata). A rough, coarse, perennial grass, extremely hardy ; of all grasses the best for sowing under trees or in orchards; furnishes abundance of pasture during the entire season, wet or dry; makes excellent hay mixed with clover. Sapling or Alsike Clover is best to sow with it, as it ripens about same time. Sow in September or Spring, at rate of $11 / 2$ to 2 bushels per acre. Weight per bushel 14 pounds. This seed has been in great demand by English and other foreign dealers. It grows about two and one-half feet high, producing an immense quantity of leaves and ioliage. On account of its earlibess and quick growth it is of exceptional value for permanent past ures. It furnishes the first green bite in Spring and the last in the Fall ; is quick to recover from close croppings, even thrives better the more it is cropped, and is heartily relished by all kinds of stock. It should not be sown alone, as it grows in tufts, but in a mixture with other grasses it should be included, so as to get a close and even sod. Bushe1 $\$ 1.75$ to $\$ 2.06$; peck 50 to $75 \mathrm{c}$; pound $20 \mathrm{c}$.

Herd or Red Top Grass (Agrostis Vulgaris). Fourteen pounds to the bushel. This is a good, permanent grass, and makes a perfect sod. It is the best grass that can be sown on washy lands for holding the soil. In most sections it is highly appreciated for hay, succeeding Clover and Timotby when they have dried out. It is a good forage plant when kept fed close. It never grows so coarse or hard but that the stalk is sweet and tender, and eaten without waste. It should enter largely into a mixture with other grasses. Sow two bushels to the acre. Pound $10 \mathrm{c}$; subject to market price.

Red Top Fancy. Cleaned from chaff and is solid seed. (About 50 pounds to the bushel). Three pounds thus equaling one bushel of ordinary Red Top. Unlike ordinary Red Top, it can be sown at same time with other grasses, thus avoiding going over the ground the second time. Pound $20 \mathrm{c} ; 14$ pounds $\$ 1.90 ; 100$ pounds $\$ 13.00$.

Red Top grows almost everywhere, but in 'a moist soil it reaches its highest state of perfection; is good for pasture and also lawns. There is a great difference in the grade and qualities. The low-priced seed is really nothing but the chaff and hulls of the Choice and Fancy Cleaned, and contains but a small percentage of germinating seed.

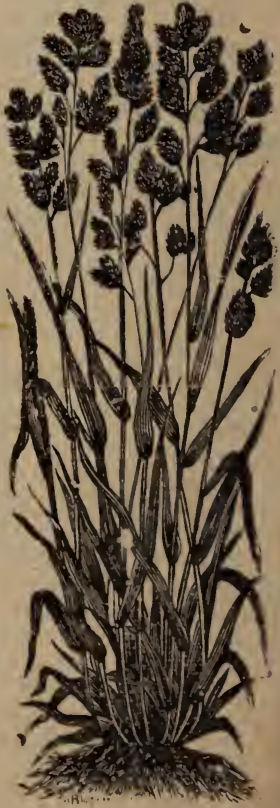

ORCHARD GRASS. 


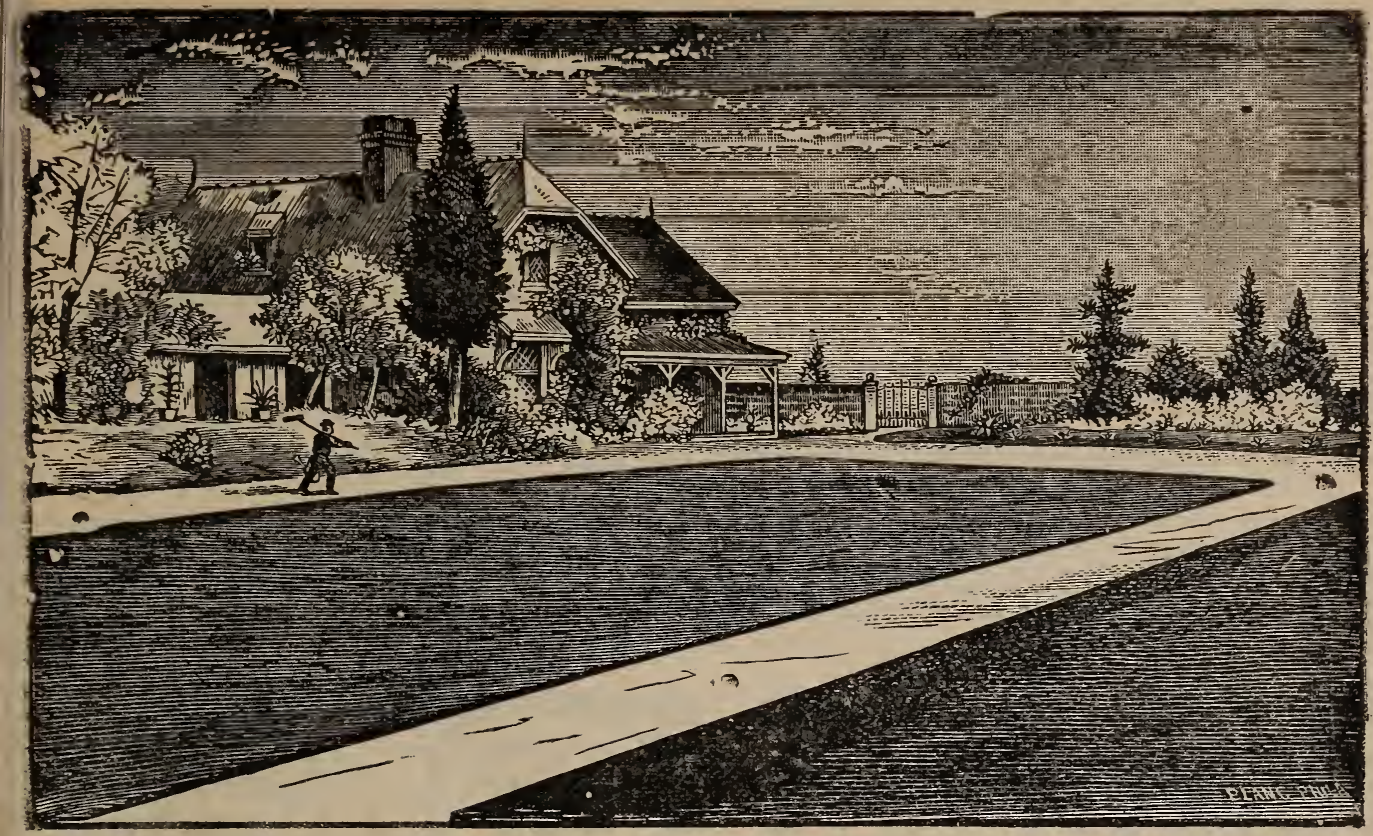

\section{LAWN GRASS SEED.}

THE LAWN GRASS which we offer should not be compared with the cheaper preparations advertised. Our combination is of the best chosen varieties and clear of weed seeds. Any one who purchases cheap, illchosen Lawn Grass will soon realize that it is a poor investment, as the crop is a constant reminder of a poorly considered purchase.

Much of the success of lawn making depends upon the preparation of the ground. The land must be well plowed or dug, and harrowed or raked, to secure thorough pulverization, and, if possible, well rolled down and top dressed with a good fertilizer, unless the land had received an application of well-rotted stable manure before plowing or spading, and we would recommend a good grade of super-phosphate or a mixture of phosphate, ammoniated bone, as especially adapted for lawns, at the rate of 500 pounds to the acre, which should be lightly harrowed in and upon the seed bed. Our Lawn Grass Mixture should be carefully sown at the rate of three or four bushels to the acre, lightly harrowed in and thoroughly rolled. When the young shoots of grass have attained the height of three or four inches it should be carefully mown with a sharp scythe; after this it should be mown about every ten days with a lawn mower. Frequent mowing is indispensible to maintain turf In good order.

When your lawn has already been established, you wili find it greatly to your advantage to renew it every season. As early in the spring as the weather will permit, have your lawn carefully raked so as to remove the dead grass and leaves that may be thereon; then sprinkle it withour Mixed Lawn Grass Seed, which will renew the thin places and spots which have been killed by winter; then give it a dressing with our Lawn! Fertilizer Mixture, and finish by giving the whole a thorough rolling; after which the lawn mower should be used every week or ten days. This will make the lawn a source of ever-varying beauty and enjoyment throughout the season.

We have tried all kinds of Lawn Grass Seed, both native and foreign, and confidently recommend our Mixed Lawn Grass Seed as the best in use. It makes a quick and luxuriant growth, and permanently occuples the ground, giving it a velvety evergreen sod, which is the charın of a lawn. Put up in packages or as wanted.

The Henry Philipps S. \& I. Co. Fancy Park Mixture

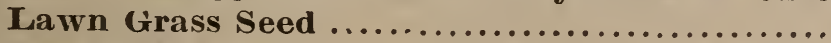

Lb. Peck. Bushel.

The Henry Philipps S. \& I. Co. Common Mixture

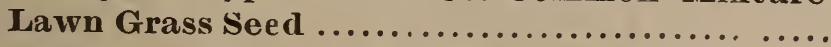
$\$ 0.20 \$ 0.65 \$ 2.50$ $.15 \quad .5002 .00$

We wholesale our Lawn Grass Seed put up in lithngraphed cartons of one pound-two dozen per case, and shall be pleased to have dealers write for prices.

If sent by mail, add 10c. per pound to prepay postage. Special price in larger lot. 


\section{PIONEER FERTILIZERS.}

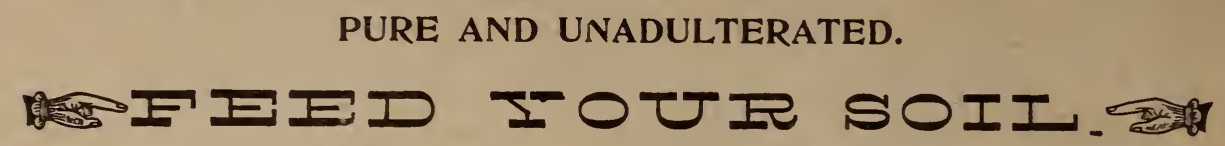

Commercial Fertilizers are sure to come into more general use as fast as they are tried. Their quick and direct action commend them to the gardener and the farmer. A customer who once buys almost invariably continues its use. The enormous quantities sold every fear give the best evidence of its utility and value to the gardener and farmer.

\section{OUR FARMER AND GARDENER FRIENDS.}

Life is too short for the intelligent to spend any great portion of it in wading through the long drawn out publications of some fertilizer companies. You know that your land needs manure and we know that we have the goods that will suit you. Bone Fertilizers are the most valuable, and though they cost a little more than the South Carolina Rock, at the start, they a re cheapest in the end.
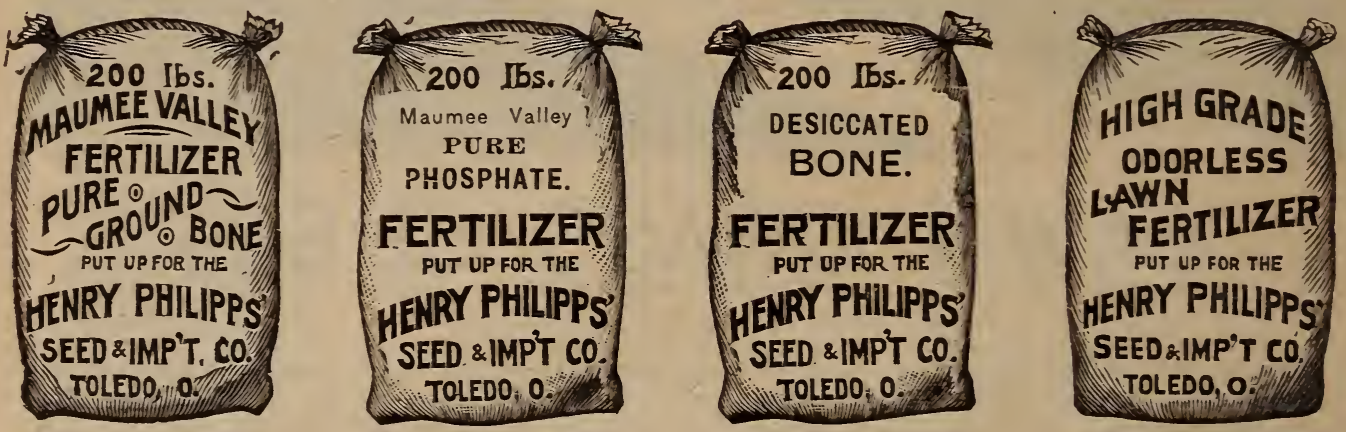

Iaumee Valley Pure Ground Bone. Pure Bone Meal analysis : Ammonia. 650 per cent. ; Bone Phosphate and Phosphoric Acid, 25.27 per cent.; Potash 0.90 per cent. Every bag guaranteed pure bone. Price, per bag of 200 pounds, $\$ 3.50$; in ton lots, $\$ 30.00$. Harrow or drill in, using 200 to 300 pounds per acre at time of seeding. Small lots by express, not prepaid, 5 pounds 25 cents; 10 pounds 50 cents ; 25 pounds $\$ 1.00$.

Manmee Valley Pure Phosphate. State analysis: 4.50 Ammonia; Phos. Acid, 15.48; Potash 0.80 per cent. This brand of Fertilizer is the best and purest of its kind made. It consists of animal meat and bone only is very strong, most excellent for wheat, corn, potatoes and vegetables. Price, $200 \mathrm{lb}$. bags $\$ 3.00$; in ton lots $\$ 2.00$.

Desiccated Bone. Guaranteed analysis : Ammonia 1.50 to 2.50 per cent. ; Phosphoric Acia 25 to 30 per cent. ; Bone Phosphate 55 to 65 per cent. Is a pure animal bone, without adulteration, from which all the grease and gelatinous matters have been extracted by a patent process, leaving the resultant bone in a finely divided state. Numerous tests have shown that the results from using Desiccated Bone are more satisfactory than those with Raw Bone, because the former is more quickly decomposed in the soil, and the phosphoric acid is more readily rendered available as food for growing plants. Price, 200 pound bag $\$ 4.00$; in ton lots $\$ 37.50$.

Recommended for use on bottom lands or where there is a good supply of moisture for all kinds of grain, and also for strawberries and fruit trees, in connection with some form of potash. May also be used to good advantage composted with barnyard manure.

\section{PIONEER LAWN DRESSING.}

No weeds. No litter around your house. Old and new lawns require stimulating in Spring or in the Fall after season of cutting and heat of Summer. It is chemically prepared, containing only elements to make grass growth; has never failed to produce a rapid and rich green velvety lawn. By using this dressing all the unsightliness and disagreeable odors are avoided. No weed seeds will fill your lawns as they frequently do when stable dressing is used. It is very lasting, and by its use worms and other troublesome insects are driven from the soil. Should be sown broadcast at the rate of 600 or 800 pounds to the acre, according to condition of lewn. 100 pound bag $\$ 2.25 ; 50$ pound bag $\$ 1.50 ; 25$ pound bag $\$ 1.00 ; 10$ pound bag 50 cents. 200 pound bag $\$ 1.00$; special price for larger quantity. 
Nitrate of Soda. This is valuable solely for the nitrogen it contains, equal to 20 per cent. of ammonia. It is chiefly a stimulant: it is used in addition and mixed with barnyard and other fertilizers. It comes from Chill, and is very quick in its action and hastens the maturity of crops. Price, nominal, sack $200 \mathrm{lbs}$. $\$ 6.50$; half ton, $\$ 30.00$; ton lots, $\$ 55.00$.

arariate of Potash. Contains 50 per cent. actual potash. Price, nominal, per bag of about $2211 \mathrm{bs}$. $\$ 6.50$; per ton of 2,000 lbs. $\$ 55.00$.

Prices on Nitrate of Soda and Muriate of Potash are subject to market fluctuations.

Pare Peruvian Guano. (Genuine Lobos brand). Free from adilteration. One 1b. 10c; $101 \mathrm{bs} .75 \mathrm{c} ; 251 \mathrm{bs}$. $\$ 1.50 ; 50 \mathrm{lbs} \$ 2.50 ; 200$ lbs. $\$ 2.00$; per ton of 2,000 lbs. $\$ 55.00$ One ton of pure guano is worth twenty tons of stable manure. "Mixed in water (like Paris green) it is most valuable in forcing garden truck, both in hotbeds and out in the field.

Land Plaster or Gypsum. Analysis: Sulphate of lime, pure gypsum, 9123 ; carbonate of magnesia (a valuable fertilizer), 2.65 ; common lime stone, 2.20 ; alumni silica and oxide of iron, 92 , We have the genuine New York State gray only, and this Land Plaster used as fertilizer gives better results for money invested than anything a farmer can put on his land. Valuable for all crops, especially in dry seasons where commercial fertilizers fail. Used by many potato growers. This is excellent to mix with Paris Green at the rate of 100 pounds of Plaster to 1 pound of Paris Green. Per barrel of about 300 pounds, on cars, $\$ 1.50 ; 5$ barrel lots, per barrel, \$1.25.

Ashes-Canada Unleached Hard Wood. Nature's fertilizer. Contains all of the fertilizing elements Ashes correct sourness of the soil, rendering sandy soils more capable of retaining fertilizers and making clay soils less stiff and more easily worked. They drive away insects, and are indispensable for all crops requiring potash. They are very beneficial for garden and field crops, and are of high value for cabbages, potatoes, onions, strawberries, celery, fruit trees, corn, clover, wheat, beans, grass lands and lawns. Price, per barrel of about $200 \mathrm{lbs}$., $\$ 2.50$; per ton of $2,000 \mathrm{lbs}$., $\$ 20.00$. Special price in larger lots.

Please let us $\mathrm{know}$ for what crop and on what kind of soil you wish to use fertilizer, and we will be pleased to write you what we consider best for your use.

Bowker's Food for Flowers An excellent fertilizer for house plants. Easily applied by dissolving in water. Clean to handle; without odor; produces rich green growth and profusion of flowers. Price, large packages, $25 \mathrm{c}$; or by mail, $40 c$.

\section{POULTRY SUPPLIES.}

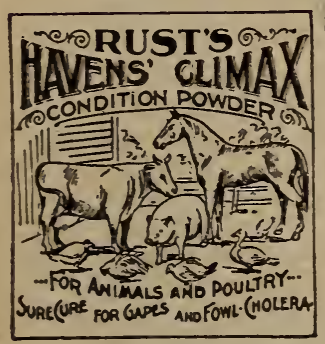

Rust's Havens' Climax Condition Powder.

\author{
Is exactly what every Farmer and Poultry Raiser Needs.
}

Keeps stock and fowls healthy. It always cures Gapes and Fowl Cholera, when used as directed. It expels worms from Horses, etc, harmlessly. It improves and increases the production of milk. It makes Hogs thrive and fatten. Try this. It is the only reliable Poultry Powder. It is not a feed, but an honest medicine at an honest price. All/who have used it once will have it again. Price, one package, $25 \mathrm{c}$; if by mail, 15c. extra for postage. Five pound box (equal to 6 packages), $\$ 1.00$. Full descriptive circulars and anything else in line of Poultry supplies wanted, will be furnished on application.

\section{LiNSEED OR OIL CAKE MEAL.-Genuine Old Process.}

Experienced feeders claim it to be the most profitable food for Beef Cattle, Cows, Horses, Sheep, Hogs, Fowls, etc Keeps stock in a healthy condition Makes fine, palatable meats more tender and juicy. A wonderful food for milch cows-increased quantity and quality of milk, butter and cheese. A double gain in rich manure that is left. Oil Cake Meal, like cooked food, is easily digested and shows good results. Prices subject to change. Price per 100 pound bag, $\$ 175$; per ton, $\$ 3200$. No charge for bags. Royal Stock Hood for Horses, Cattle, Hogs, Sheep and Poultry. For large lots apply for prices, as we may be able to sell for less than here quoted.

\section{BUCKEYE HOG CHOLERA CURE.}

Makes hog raising profitable. An absolute prevention and cure for Hog Cholera. It will put your hogs in first-class condition, stop cough and regulate the bowels; arrest disease in every instance; destroy worms : repay its cost many times over in the extra pounds of pork it will make without extra feed. Price, 50 c. a pack: age; $\$ 1.00$ per dozen. Agents wanted.

\section{COARSE GROUND BONE FOR POULTRY.}

This is about the size of wheat, and can be fed like any other food, in grain. The phosphate of lime con. tained in bone assists in the formation of the egg and largely increases the productiveness of hens. Price, 1 to $10 \mathrm{lbs} .5 \mathrm{c} ; 15$ to $50 \mathrm{lbs}$. $3 \mathrm{c} ; 100 \mathrm{lbs}, 2 \frac{1}{2} \mathrm{c}$; in ton lots $2 \mathrm{c}$. per $1 \mathrm{~b}$. 


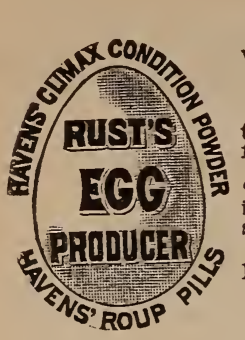

RUST'S EGG PRODUCER supplies those substances, which, when assimilated by fowis. produce

\section{EGGS, GROWTH AND DEVELOPMENT.}

It contains the elements of eggs, and therefore makes hens and tardy pullets lay, exactly as certain foods produce milk in cows or

Although at half the usual price, it is not too cheap to be the best " "Hen Persuader," or Egg Food known. It is so excellent in quality, and so moderate in price, that everybody keeping fowls should use it in summer and winter

It makes egg producing profitable. Full directions on each package. PRIOES:-1 lb. package, 25 centa; 21/2lb. box, 50 cents; $6 \mathrm{lb}$. box, \$1.00; $10 \mathrm{lb}$. box, \$1.50; $25 \mathrm{lb}$. keg, \$3.25. If by mail, add 16 cents per lb. for postage.
"MASCOT"

Drinking Fountain FOR FOWLS.

The best thing yet, Is as convenient to fill and empty as a water pail. Chicks will not get. drowned in it. Price 1 gallon size, 50 c.

\section{GROUND OYSTER SHELLS AND CRYSTAL GRIT.}

Both important articles for the poultry yard through the Winter, and should be liberally supplied to the fowls. When everything is frozen or covered with snow, they must be helped out if eggs are wanted. The fact that our "Excelsior Oyster Shells" are ground when green. makes them valuable as an aid in the digestive organs of the fowl. Price, 1 to $10 \mathrm{lbs}$. 2c;20 lbs. 35c; 50 lbs. $75 \mathrm{c} ; 100 \mathrm{lbs}$. $\$ 1.00$; barrel 75c. per 100 Ibs. Special prices on larger lots. Crystal Grit same price.

\section{PURE FINE GROUND BONE FOR POULTRY.}

For young chicks whose power of digestion is not mature, this will be found an indispensable addition to their food. Price, 5 lbs. $25 \mathrm{c} ; 10$ lbs. $40 \mathrm{c} ; 50$ lbs. $\$ 1.5 \mathrm{~J} ; 100$ lbs. bag $\$ 2.50$.

\section{DEODORIZED BLOOD MEAL.}

Blood Meal is a valuable supplemental food for Poultry. Don't fail to give it a trial. Ten $1 \mathrm{~b}$. packages 50c : $50 \mathrm{lb}$. bag $\$ 2.00$; special price in larger lots. For more full information, apply for special circular.

Mixed Chicken Feed, from 50c. to $\$ 1.00$ per 100 lbs., as to quality.

Rust's Havens' Roup Pills 25 cents per box.

Bockley Phillips' Stock Food....

"6 Egg Producer

50 " " package.

"6 Louse Killer.

Sunflower Seed, Russian Mammoth.

Barley for Hens

Buckwheat for Hens

Millet for Chicks -at 25 25 "

10 “

China Nest Eges

Slug Shot-Insect Destroyer.

75 .

50

25

Lee's Lice Killer

-at 25

25

66 “6 600

Sturtevant's Vermin Killer.

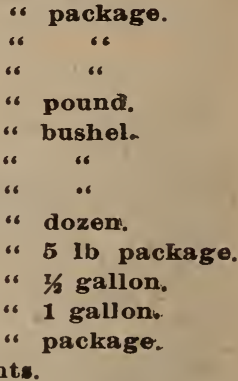

pound.

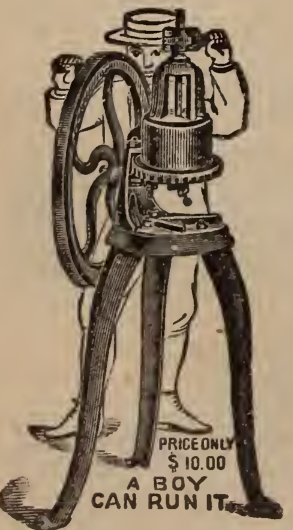

\section{MANN'S \& STEART'S HAND AND POWER New Green Bone Cutters,}

Will successfully cut Fresh Market Bones, with meat and gristle attached. Valuable implement for the Poultryman, Gardener and Housekeeper.

OUR WARRANT.-Every machine warranted to cut dry or green boues with the meat and gristle attached, without clog or difficulty, or money refunded.

1902 PRIOE LIST.$$
\text { No. } 5 \mathrm{C}
$$$$
\text { (with Crank Handle) }
$$$$
\text { “6 } \mathrm{H}
$$$$
\text { -(with Balance Wheel) - }
$$$$
\text { “6 } 5 \mathrm{~B} \mathrm{M}
$$$$
\text { (with Balance Wheel and Iron Stand) }
$$$$
\text { “7 } 7
$$$$
\text { “9 } 9
$$$$
\text { 16 } 11
$$$$
\text { “ } 12
$$$$
\text { “ } 15
$$

No. 14

(with Balance Wheel and Iron Stand)

8

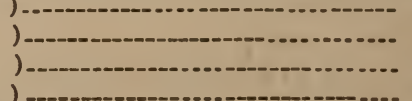




\section{RELIABLE INCUBATORS.}

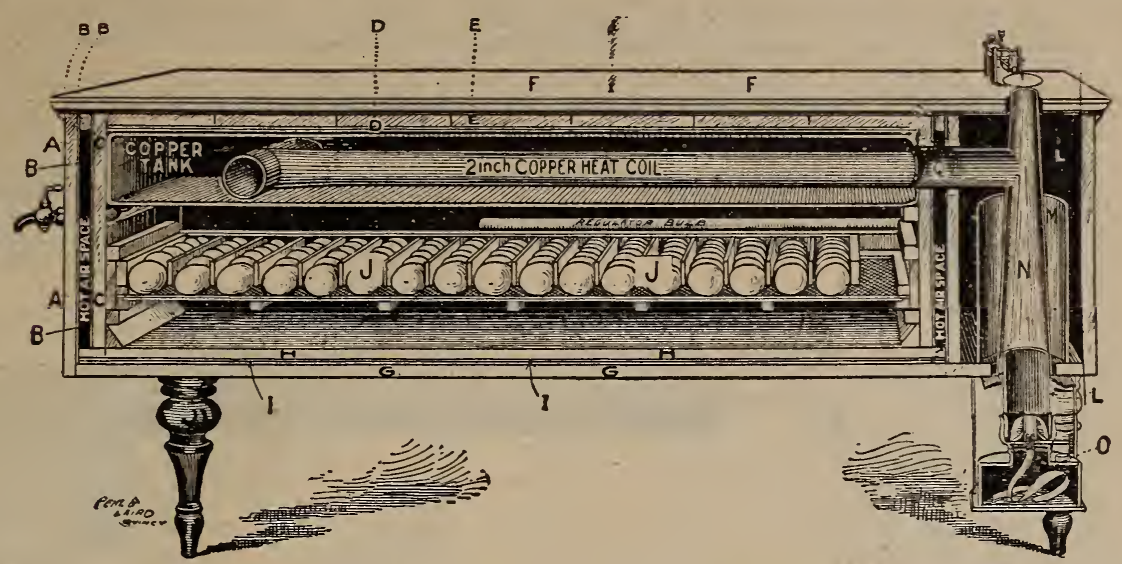

Sectional View of New No, 3 Hot Water Incubator.

Price List of New No. 3 Copper Tank Hot Water Incubators.

WITHOUT BROODER OR YARDS.

No. 1-100-Egg Size...........................\$26 00

No. 2-150-Egg Size..................... 2800

No 3-200-Egg Size............. 3000

No. 4-300-Eyg Size............................ 4400

No 5-400-Egg Size........................ 5000

Hot Air Incubators, as well as the Hot Water Machines, have Copper Lamps, Thermometers, Egg Testers and are guaranteed in every way.

Price List of New No. 3 Hot Air Incubators. WITHOUT BROODER.

No. 1-100-Egg $\$ 4000$

No. 2-200-Egg 2500

No. 3- 300-Egg

3500

No. 4-400-Egg 4200

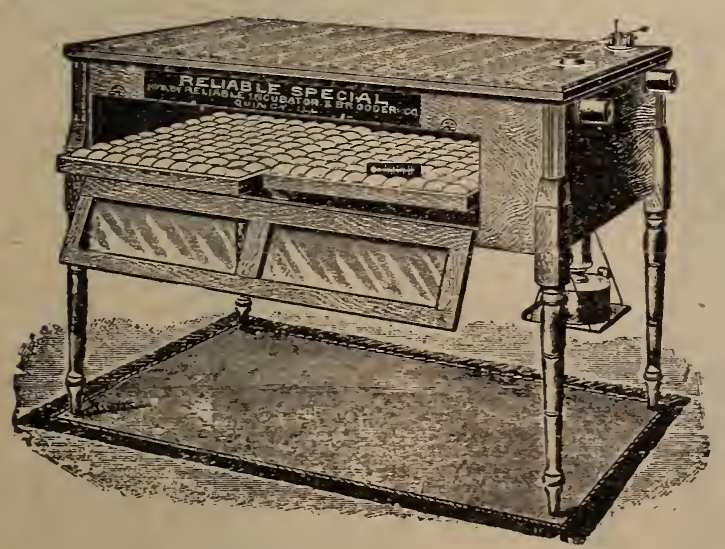

WITH BROODER COMBINED.|

No. 1-100-Egg Size. $\$ 3000$ No. 2-150-Egg Size_..._._._._._._._.............. 3300 No. 3-200-Fgg Size...................... 3750 No. 4-300-Egg Size_......_-_._._............... 5000 No. 5-400-Egg Size......................... 6000

Please remember these Hot Water Incuba. tors have Copper Tanks and Pipes, and are the very best Incubatcrs made.

-

WITH TOP BROODER COMBINED.

No. 1-100-Fgg. $\$ 2400$

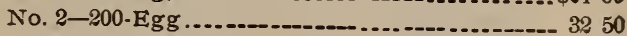
No. 3-3' 0. Egg -.._-

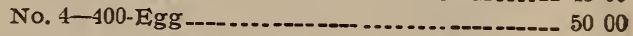

We offer the Reliable Special Hot Air Incubator (like cnt), that we can sell as follows, and can guarautee that you can buy no Incubator for anything like the money that will give the satisfaction these Specials will:

100-Egg-Size, Reliable Special .........-_\$1200 200-Egg “ “ “ “ 300 -Egg “ " " 400. Egg “ “ “

SEND US YOUR ORDER.

Star Incubators.

No. 12-120-Kgg Size........................... $\$ 1900$

No 15-190 " "

No. 16-250 " "

No. $20-380$ " "
No. 1-60-Egg Size, Single Case_............... \$6 00

No. 2-60 " " Double " - " 60 "

No.3-120 " " Si gle " .

No. 4-120 " " Double " 


\section{SPRAYING OUTFITS.}

Nearly everyone is now familiar with the practice of spraying plants with various insecticides and fung:cides, for the prevention of injury by insects and fungus diseases. It has been estimated by competent authorities that over $\$ 300,0,0,000$ worth of crops are annually destroyed by insects and fungi in the Unlted States. But by proper spraying a large part of this immense loss can be prevented.

The spraying should be done by means of a spray pump, many styles of which are on the market. To do satisfactory work in spraying one must have a first-class outfit. The pump must have its working parts made of brass, as the fungicides soon corrcde iron or tin. The nozzle must be of good quality, it must throw a fine mist like spray, and if it will throw a solid stream, so much the better for its general utility. The kind of spraying outfit which should be selected will depend entirely upon the kind and amount of w rk to be done.

We here offer to our friends and customers a complete line of spraying appliances, such as we consider good in every way, and the best made for the price asked. The different Sprayers we offer can be used in many ways for spraying the garden, orchard or vineyard by florists, nurserymen, fruit and tobacco growers, poultrymen and stock raisers.

\section{LIGHTNING SPRATER.}

This little liquid Sprayer weighs one pound. Is cheap and durable and will soon be wanted by every farmer and gardener in the country. Once flling will cover 1.000 hills of potatoes. This is the best Sprayer for farmers' wives to spray house and garden plants, disinfecting rooms, for use in the laundry and anywhere that spraying of any nature of liquids can be used. The best Sprayer for

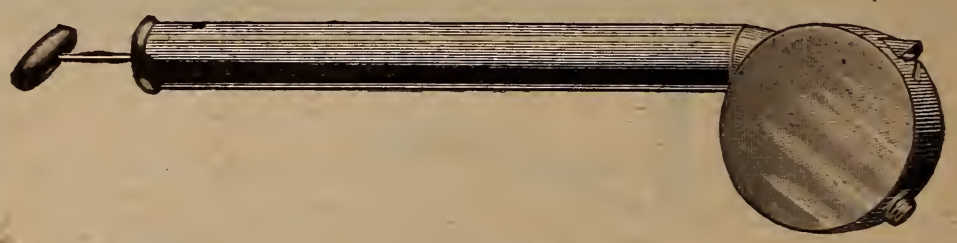

LIGHTNING SPRAYER.

barn use to keep flies of stock, etc. Price low and within reach of all. Tin, 50c. each : brass, $\$ 1.00$. by express.

These machines have been used by the leading florists and gardeners in the United States, with the greatest degree of satistaction. It throws a spray as fine as a cloud of smoke, which being damp, adheres to the plant ; it is worth its cost many times each season to any household; it will surely disinfect any place, and destroy any living insect if the proper liquids are used. Kerosene emulsion may be used on most any kind of plant without harming same. When using operate with a quick stroke.

CARE OF SPRAYER.- - Keep the leather plunger soft and pliable with a few drops of lard oil or a little vaseline. If small tuhe entering cup at point of air chamber clogs, remove obstruction with small wire; always rinse cup well with clean water, and dry before putting away. With reasonable care it should last for years.

\section{Double Acting Spraying Force Pnmps.}

Aquaject Portable Hand Force Pumps. The easiest and most powerful Garden Force Pumps ever produced. Fitted with suction hose to draw water or other liquids from a pail or other source, even 20 or more feet off. A perfect miniature fire engixe of brass and malleable iron. Serviceable for home, garden, orchard, washing buggies, etc. With suction and discharge hose, brass discharge pipe and sprayer and agitator. Price, complete, $\$ 1.50$.

Philipps' Improved Bucket Spraying Pump. This all brass hand force Pump, has all the latest improved points, and we guarantee every Pump to give entire satisfaction. Price, $\$ .50$.

No. 1 Brass Portable Spray Pump. Represents our new Brass Portable Spray Pump equipped with "Calla" spray nozzle. This pump set in bucket, requiring no suction hose. It will be noticed that this Pump is provided with agitator, especially adapting it for spraying. We furnish discharge hose, etc.

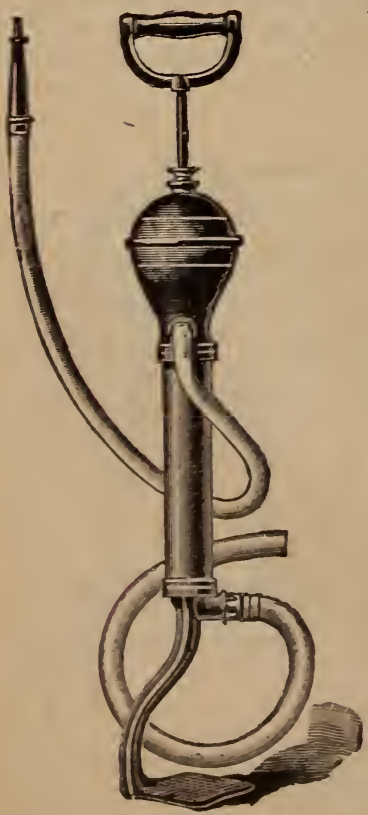

AQUAJECT.

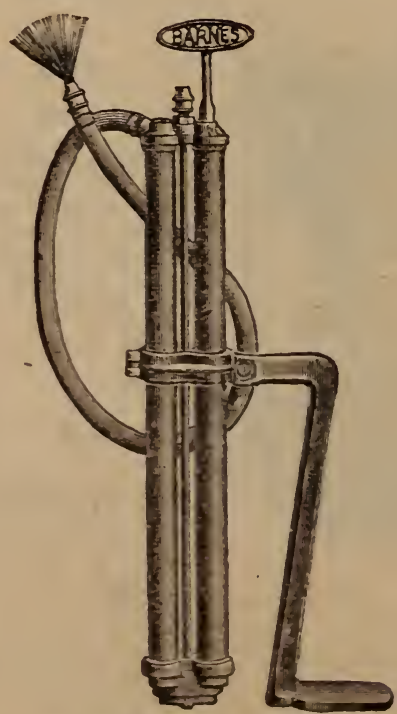

PHILIPPS' BECKET PUNP.

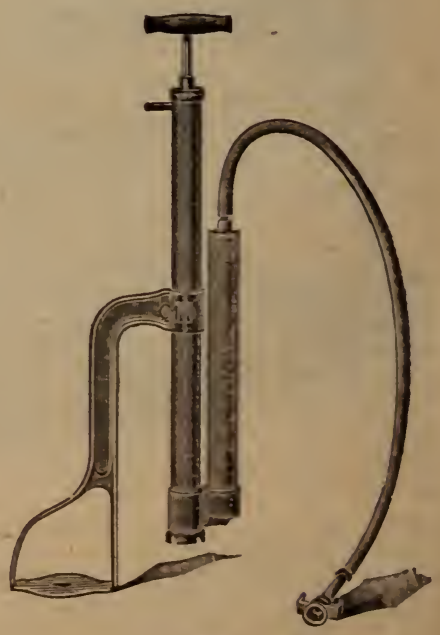

No. 1, 
(SPRAYING OUTFITS-CONTINUED )

\section{SPRAYING FRUIT TREES BY HAND AND HORSE POWER.}

\section{Spraying is No Longer an Experiment, but a Science and a Necessity to Secure a Crop of Fruit.}

Outfit B. Döble Acting Spray Pump, with base for attaching to either side or top of barrel. This Pump has brass-lined cylinder, brass cased differential plunger, and large air chamber. Price, $2 \frac{1}{2} \mathrm{ft} .1 \mathrm{in}$. iron suc-

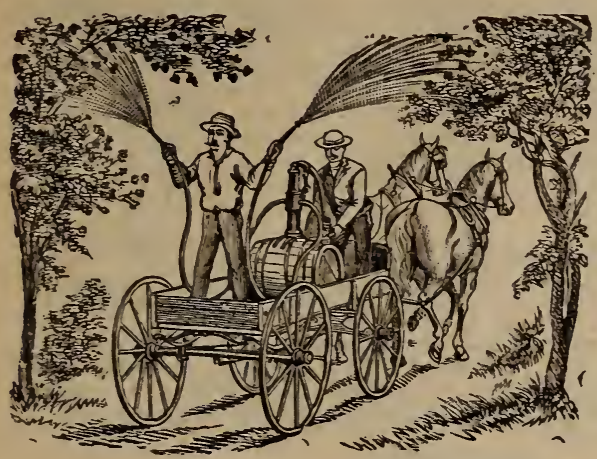

tion pipe with brass strainer and two leads $10 \mathrm{ft}$. each $1 / 2$ in. discharge hose with Mason (or other) spray nozzle, $\$ 10.00$. For a pump with one lead hose only $\$ 8.50$.

These Outfits can be mounted on wagons and plank sleds at very trifling expense and trouble. We can guarantee these outfits to give good satisfac tion, so our customers run no risk in ordering them. The price of Leggett's Gun complete, with 4 extra tubes, 5 nozzles, ;oil can, 2 straps, as illustrated, is \$7.50. Circular gives full information as to the mix. tures and cost of different powders, etc., with each Gun.

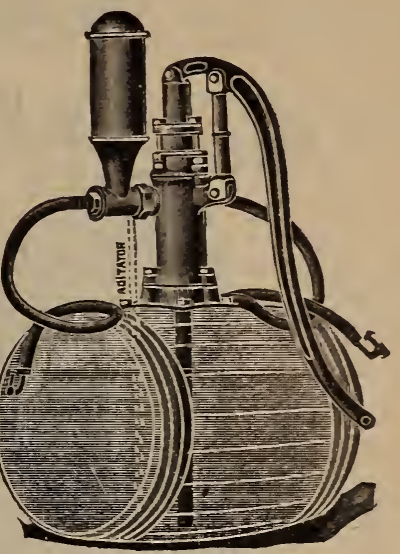

OUTFIT B.

LEGGETT'S PARIS GREEN OR DRY POWDER GUN.

For Orchard, Vineyard, Garden or Potato Field. Distributes Paris Green, Sulphur, "Fungiroid," (a powdered Bordeaux Mtr. ture) or any dry powder. ThousandS IN USE Illustrated Circular on application.

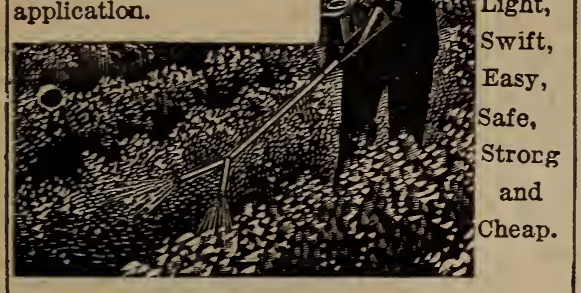

Outfit $P$. Represents our New Improved BARREL SPRAY PUMP with brass upper and brass-lined lower cylinders, brass plunger, brass check valve and brass valve seats. All working parts coming in contact with the liquid are brass. The body of the Pump is a large air chamber and after the Pump is under pressure it will discharge a steady spray lasting two minutes or more witb one stroke of the handle, thus making it easy to operate. Is double-acting. discharging half of water on up-stroke and half on down-stroke of handle. The ease with which it is operated makes it a generai favorite, and we gusrantee it to give perfect satisfaction. Price, 1 Lead Hose, $\$ 50 ;$ with 2 Leads Hose, $\$ 10.00$.

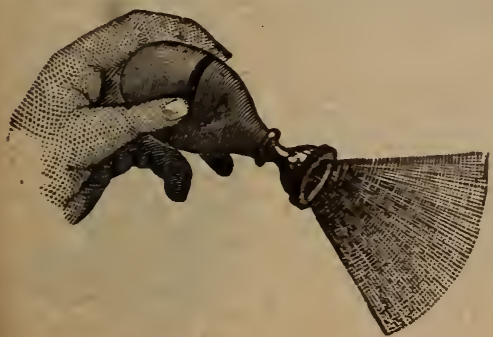

Scollay's Rubber Sprinkler. Indispensable for floral work and gardening. Invaluable when once tried very useful for dampening clothes or sprinkling in any way. Beware of imitations, as this is the best. Price, $\$ 1.00$. Same style medium, 75c. Small, $5 \mathrm{Cc}$. 


\section{Philipps' "Handy" Knapsack Spray Pump.}

For Orchard, Vineyard or Field Service.

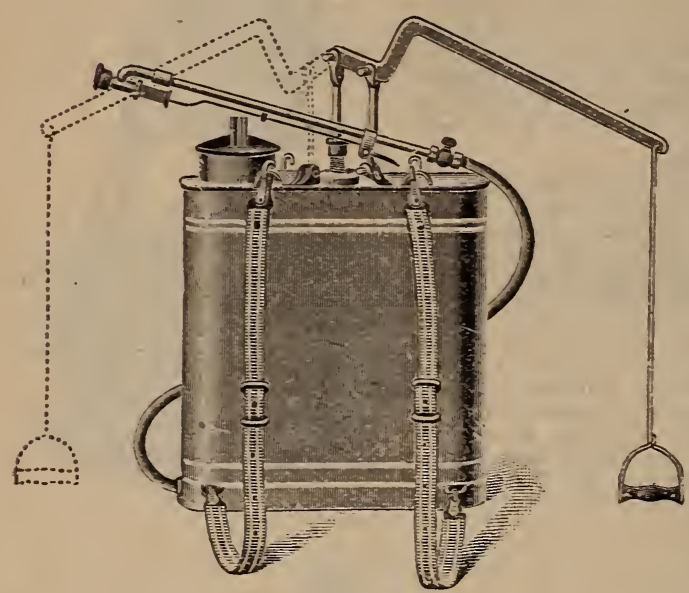

Our Improved Knapsack Sprav Pump which we have designed and which experience will, we feel confident, prove the best pump of this character upon the market. The pump itself is made entirely of brass and copper, with rubber ball valves and metal plunger, sll of which are ea -ily accessible, and can be, therefore, readily examined and re. paired. It is so arranged and stayed in the reser. voir that it is capable of doing long and continuous service and will not easily get out of order.

The discharge in our New Improved is at the bottom, and the pump can, therefore, be entirely drained of the liquid. You can arrange Pump in the reservoir to be operated by either the right or left hand. as desired, allhough we shall make them locating the Pump to be operated by the right hand, unless ordered otherwise The reservoir is made of heavy copper, and will hold about five gallons of liquid.

"Handy" Knapsack Sprayer complete, as shown in cut, with $3 \frac{1}{2}$ feet of $3 / 8$ inch Discharge Hose and Vermorel Nozzle. $\$ 10$ a.: less Vermorel Nozzle, \&inch Lance and Lever, $\$ 8.50$.

\section{PHILIPPS' HORSE POWER SPRAYER.}

Especially designed for Spraying Nursery stock, Grape Vineyards and Potato fields. This machine has a beavy hard-wood frame, and tank holding 50 gallons: has strong iron whet ls 3 fet $t 2$ inches in diameter, 3 lnches wide. Price, piped for vineyard Spraying. with thills for one horse. with four Vermorel Nozzles, $\$ 5000$ : price, piped for Spraying Potatoes, with pole for two horses, with three Vermorel Nozzles, $\$ 60.00$. Two iu-foot

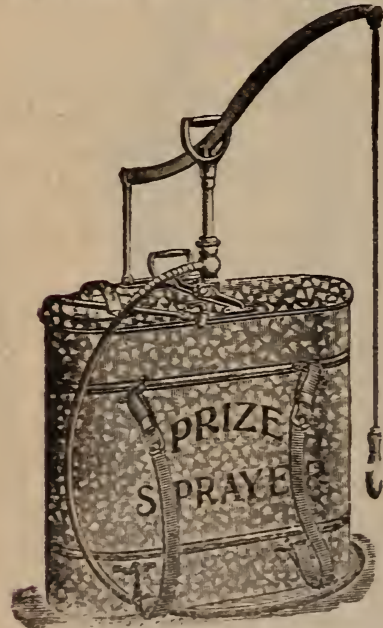
sections of hose and two Vermorel Nozzles for orchards. We sold several of them and they have all given the highest satisfaction. For more full expla. nation of the machine ask for special circular of same.

The "PRIZE" Knapsack Sprayer is provided with special attachment for clamping the pump (which can be easily removed) to tank, and has a BANDLE by which tank may be CARRIED ABOUT after TEmoving the lever and its handle. In this way it can be used SIMILAR TO A BUCRET PUMP. Horiculturists will appreciate this novel ftature. The price is very low-only $\$ 600$.

TVorking parts of the Pump are brass, which will resist the action of acids contained in the fungicides.

A Return Stream Agitator made by a hole tbrough the lower valve stirs the liquid and keeps the strainer free from sediment No OTHBR $\triangle$ GITATOR of this kind will so rHOROUGHLY AGITATE the spraying solution.

Nothing could be more convenient than this apparatus for use in greenhouses and in gardens. It is an excellent potato sprayer where any solution is used except Bordeanx Mixture and Ammoniacal Solution of
Copper Caibonate. To resist the action of acids, a copper tank is preferable.

The "SUCCESS" represents a new and excellent Pump for use in gardens, vineyards, greenhouses, for washing windows and huggies: also for spraying poultry houses. THE WORKING PARTS ARB ALL BRASS and bucket foot-rest is made of malleable iron. Nothing could be simpler and more durable than this Pump. It has large air chamber space and is double acting, throwing an absolutely continuous stream, either SOLID or in FINE SPRAY. The end of bose connecting to pump is coiled with brass spring wire, adding largely to its durability. The "Bordeaux" Nozzle, the best combination spraying Nozzle on earth, is furnished with "Success" Pumps. Price $\$ 3.50$.

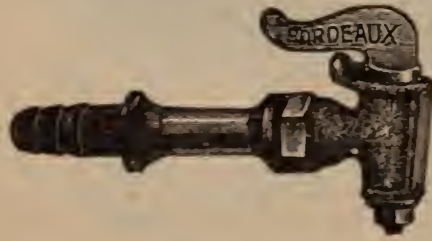

The "Bordeaux" Nozzle is the simplest and BEST combination Spraying Nozzle on the market. It throws solid stream or a fan-shaped spray adjust. able to any fineness : is readily degorged by turuing the cock handle. It will also thiow a long-distance coarser spray for spraying very large trees; or it may be shut of altogether-PBATURES POSSESSKD BY NO OTHRR SPRAY NOzZLR. It can he used with any of our Spray Pumps for both $1 / 2$-inch pipe and $1 / 2$-inch hose. Price, as per cut, 75 cents.

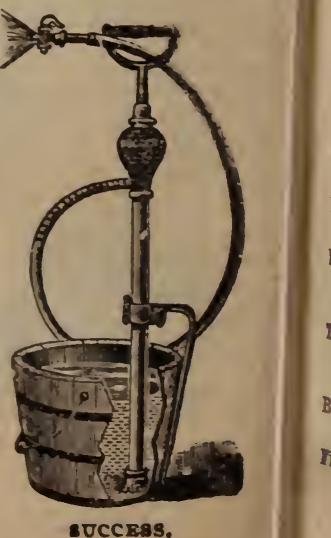




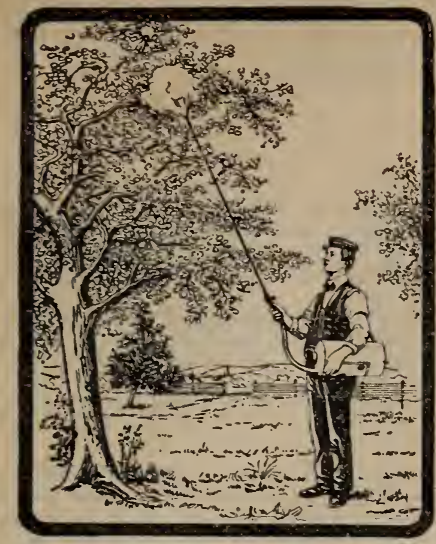

PEILIPPS' COMPRESSED AIR SPRAYER.

\section{PATENT POWDER GUNS.}
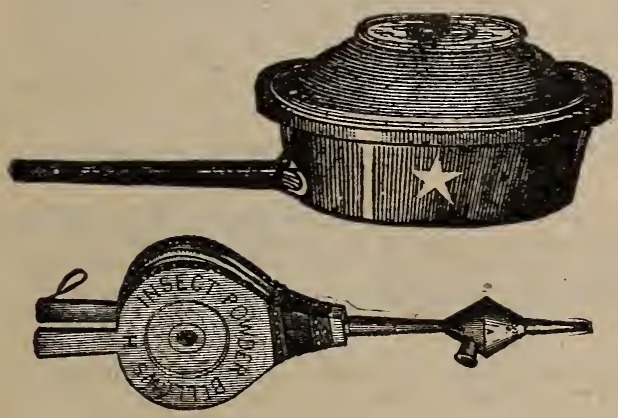

\section{PHILIPPS' COMPRESSED AIR SPRAYER,}

Pbilipps' Compressed Air Sprayer for spraring trees, small fruits potato vines, etc. Also for house use as a Fire Extinguisher and many other uses Tank holds belween 3 and 4 gallons and shonld be filled about two-thirds 1 ull, and a few strokes of the pump will immediately start the spray or solid stream, whichever you prefer. Guaranteed the best out and greatly improved this year. Each Sprayer has an adjustable safety valve, which allows the air to escape after a desired pressure has been obtained. Price, galvanized, $\$ 3.50$; brass, $\$ 5.00$.

We carry in stock a full line of Wood and Iron, also Combined Lift and Force Pumps of all Sizes; Well Curbing Fixtures, Galvanized Chain, Rubber Buckets, Iron Pipe, Wood Tubing. All of these goods sold at the very lowest prices.

\section{Prices Mailed on Application.}

We have also other Spraying Pumps, Greenhouse and Conservatory Syringes of different kinds, sizes and prices, not enumerated in our Catalogue for want of space, and will be pleased to mail circulars and give all information and prices upon application. The foregoing is a partial list of our outfits.

Scollay Putty Rulbs, for Glazing. A pressure with the hand ejects the putty a long the sash bars. Price. 75c. and $90 \mathrm{c}$. each ; by mail, $85 \mathrm{c}$. and $\$ 1.00$ Every Florist and Gardener should have one of these Bulbs.

Insect Powder Guns. The most popular in the market, with screw cap in place of cork, which allows a larger opening for filling with powder. We have several sizes. Prices, 10c., 15c., 20c, 25c. each. Per doz., $80 \mathrm{c}, \$ 100, \$ 12, \$ 2.00$. These are the best They will last a lifetime. Never fail to completely destroy Bedbugs, Roaches, Moths, Mosquitoes, Flies, Fleas on Dogs, Lice on Birds, Animals, Plants, etc.

Bellows of different sizes, with patent Powder receivers which cannot choke up. Bellows, 12.16, 24, 30 inch. Price, 75c., $\$ 1.00, \$ 1.25, \$ 1.50$, $\$ 00$.

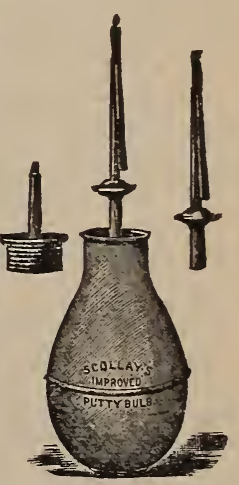

SCOLLAT PUTTY BULB.

\section{SIU G SHO'T.}

\section{AN INFALLIBLE INSECTICIDE OR INSECT DESTROYER.}

What is SLUG SHOT? Slug Shot is an impalpable powder, a com. bination of insecticides; poisonous to insects preying upon vegetables, and withal an excellent fertilizer, affecting nearly all classes of insect life. so that they either die or leave for parts unknown. IT KILLS THE POTATO BUGS in all stages of their growth. IT KILLS THE BLACK FIEAS on Cabbage, Turnips, Beets, Radishes and Egg Plants. Apply by dusting over the plant IT KILLS THE CABBAGE WORM, and also the Currant and Gooseberry Worm; the Aphis or Green Fly on Roses and other flowers Has prevented the ravages of the Curculio and Canker Worm on Fruit Trees: used for Beans, Melons. Squash, Cut Worms. KEEPS THE STRIPED BUGS FRO: ALL VINE CROPS. For full Information and testimonials from all sections of the United States apply for pamphlet "Hammond's Slug Shot and its Uses." Slug Shot is put up In 5 and 10 pound packages, and in flour barrels, loose, that contain 235

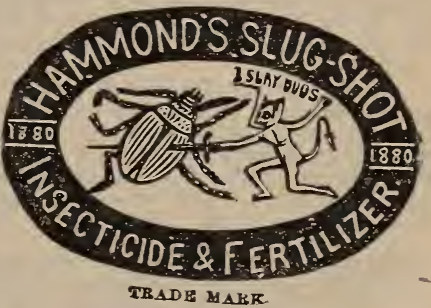

pounds each It is applied by duster or bellows Price, for 5 pound package, $25 \mathrm{c} ; 10$ pound package, $50 \mathrm{c}$; 100 pounds, 4c. pound. Full directions on every package.

Oarbolic Soap. For freeing animals from insects and washing the bark of trees and plants for scale. lice etc. Price. $4 \mathrm{oz}$. package, $10 \mathrm{c}$,, or by mail, 15c. Directions : Dissolve 2 ounces to a gallon of water and apply with brush, sponge or spray.

Whale wil Soap. An effectual remedy for destroying and pr eventing insects on plants, trees, vines, etc. ; for washing down the bark of trees. grapevines, etc. In cans with directions, 25c.

Hellebore. For destroying Rose Slugs. One or two applications are usually sufficient for a season, and it is thoroughly effective. Per pound $20 \mathrm{c}$; by mail $40 \mathrm{c}$

Pare Paris Green. For destroying Potato Bugs. It is effectual for destroying that pest. Directions for use with each package. 25c. per pound; by mall 40c 10 pounds for $\$ 200$.

London Purple. Very poisonous and equally as efficacious as Paris Green, and more soluble in water. Price, $25 \mathrm{c}$. per pound; 10 pound lots and over $20 \mathrm{c}$. per pound. If by mail, add $15 \mathrm{c}$. for postage. Use in the same way as Paris Green.

Tobacco Dust. For Cabbage Worms Caterpillars, etc. Very effective, being leaves and not gronnd stems; much used in vegetable hot-houses. Found $10 \mathrm{c}$; by mail, post paid, $25 \mathrm{c}$; express, 10 pounds, $50 \mathrm{c} ; 25$ pounds $\$ 1.50 ; 100$ pounds $\$ 300$.

Blue Vitriol. Now very extensively used in spraying grapevines, in large vineyards and orchards. Price, from 6 to 10 cents per pound, according to quantity.

Fir Tree Oil Soap. To all interested in the production of fruit and flowers, the effectiveness of FMr Tree Oit as an insecticide is well know $n$ and we recommend it as the most satisfactory yet produced. In 4 pound tins, 25c. One ounce makes one gallon mixed with water." 


\section{FORMULAS FOR PREVENTING LEAF BLIGHT AND DESTRUCTIVE INSECTS WHICH INFEST FRUIT TREES, VINES AND PLANTS.}

APPLE.-To destroy the codling moth, canker worm and apple curculio, use one pound of London Purple to 160 gallons of water. Spray the trees soon after the blossoms fall, when the apples are the size of a pea. If the best results are to be obtained, a second application should be made in a week or ten days thereafter. The second application is made necessary if the first is followed in a few days by a heavy rain.

In preparing the London Purple for use, mix thoroughly in sufficient water to a paste-like consistency; then stir into a pail of water and allow to stand over night. Strain this through a fine sieve or a coarse cloth into the distributing barrel or tank.

Paris Green has been used in many instances, but great care should be taken in not making mixtnre too strong-one-half pound being enough for 160 gallons of water.

PLUMS AND CHERRIES.-PLUM CURCULIo.-Use one-fourth pound of London Purple to 40 gallons of water, spray soon after the petals have fallen, and again ten days later. From experiments carried through two seasons, we reach this conclusion: First. -Three-fourths of the cherries liable to injury by the plum curculio can be saved by spraying as above. Second.-That enough of the plum crop can be saved by the same treatment to insure a good yield. Third - That there is no danger to health trom its use. Fourth.-That spraying is the cheapest and most practical method of preventing injuries by these insects,

PEAR AND QUINCE LEAF BLIGHT.-The fungicide to be applled is the Bordeaux Mixture, same as is used to prevent grape rot. This is prepared as follows: Dissolve 6 pounds of sulphate of copper in 10 gallons of water ; in another vessel slack 4 pounds of lime in 6 gallons of water. When the last mixture has cooled pour it into the copper solution. taking care to mix the fluids thoroughly by constant stirring. It is well to have this compound prepared some days before it is required for use. It should be well stirred before applying.

SERDLINGS.-Make five applications, the first when the leaves are one-quarter grown; others at intervals of ten days until the trees are budded.

IARGE TREES.-Spray five times, first when the fruit is the size of peas, and thereafter at intervals of welve or fifteen days.

GRAPE ROT AND MILDEW.-Use Bordeaux Mixtures sure preventive. Bordeanx Mixture (A)-Dissolve 16 pounds of Blue Vitriol in 22 gallons of water. In another vessel slack 6 pounds of lime in 6 gallons of water. 16 poun the last mixture has cooled pour it slowly into the copper solution, taking care to mix the fluids thoroughly by constant stirring. It is well to have this compound prepared-some days before it is required for use. It should be well stirred before applying. A solution containing the ingredients in the following proportions has been recommended for general use.

BORDEAUX MIXIURE (B.)-Dissolve 6 pounds of Blue Vitriol in 16 gallons of water and slack 4 pounds of fresh lime in 6 gallons of water. When cool mix the solutions as described above.

* TREATMENT.-As a first step every precaution should be taken to remove as much of the infectious material as possible. With this object in view the old leaves and rotten berries should be carefully collected in the fall as possible. With this or buried. Trimmings should zlso be burned as they often harbor thousands of the or winter and burned or buried. Trimmings should also be burned as the has proven beyond a doubt to be the most reliable preventive to black rot. In all cases it must be remembered that these treatments are pre ventives and being such it is sheer folly to wait until the enemy appears before beginning the fight.

In the spring after the vineyard has been pruned and put in order by the plow, but before vegetation starts, spray the vines thoroughly with the Bordeaux Mixture (formula A). The object of this spraying is to destroy 6pray the may be hidden away in the crevices of the bark. About ten days before the any spores of the fungus thateen parts of the vine with the Bordeaux Mixture (formula B) taking care to wet the foliage thoroughly. Spray again with the same preparation when the flowers are opening, repeating the operation every three weeks until the fruit begins to color. The necessity_for beginning the treatment early

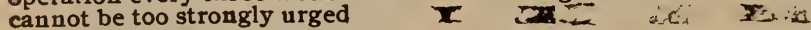

TCURRANTS, RASPBERRIES STRAWBERRIES AND GOOSEBERRIES.-Currant worms and the slugs and insects which infest raspberry and gooseberry bushes and strawberry vines, may be destroyed by one ounce of powdered white helibore mixed with two gallons of water.

PEACHES.-If sprayed at all, this fruit should be treated very carefully. Use Paris Green in preference to London Purple on this crop, seeing that it is kept constantly stirred; and do not make the mixture stronger than one ounce to 20 gallons of water. Spray late in the afternoon or on cloudy days, rather than in the hot sunshine.

TO PREVENT POTATO BLIGHT OR ROT - Use Bordeaux or Mixture, same as for grape rot, with exception of using more water. Dissolve 6 pounds of Blie Vitriol in 32 gallons of water and slack 4 pounds of fresh lime in 12 gallons of water. When the last mixture has cooled, pour it slowly into the copper solution, taking care to mix the fluids thoroughly by constant stirring. When the vines are about ten or twelve inches high, spray, and continue the operation every two weeks. By mixing with Bordeaux Mixture a solution of London Purple, one pound to 200 gallons of water, the fungus and potato bug may thus be doctored at one operation.

CABBAGE WORMS.-For destruction of the cabbage worm use slug shot.

TO DESTROY CHINCH BUGS, ETC.-To destroy suctorial or sap-sucking species of insects, including chinch bugs, squash bugs, plant lice, leaf hoppers, aphis and bark lice. use Kerosene Emulsion.

KEROSENE EMULSION is one of the most useful of the insecticide and may be easily prepared as follows : Dissolve one-half pound of hard soap (best whale-oil soap) in four pints of water by boiling; when the soap is Dissolve one-half pound of hard soap add eight pints of kerosene and agitate the whole briskly until a staple mixture is obtained. This is best done by using a force pump and pumping the mixture with force back into the vessel that contains it. The emulsion may be diluted to the desired strength and used at once or may be allowed to stand and be used from when needed. The strength ordinarily used is prepared by diluting one part of the emulsion in ten or twelve parts of water, which makes the kerosene about one-twentieth of the whole. 


\section{BINDER TWINES AND ROPE.}

\section{Quality Guaranteed.}

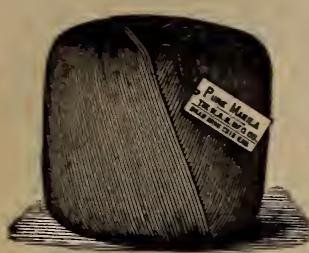

PURE MANILA.

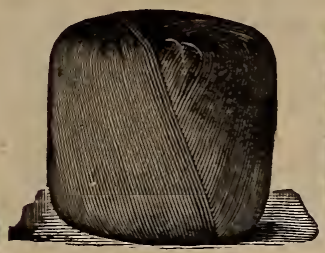

STANDARD MANILA.

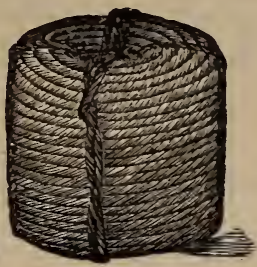

MANILA ROPE.

Pure Manila runs 650 feet to $1 \mathrm{~b}$;; Manila not pure, runs 625 feet to lb.; Standard Manila, mixed with New Zealand color same as Manila, but fibre not so good, sold by many as Manila, 600 feet to $1 \mathrm{~b}$. Pure Sisal, natural color, 500 feet to $1 \mathrm{~b}$.

Manila Rope, 1, 7/8, 5/8, 3/4, 1/2, 1/4 inch Sisal Rope, 1, 7/8. 3/4, 1/2, 1/4, 3-16 inch,

Our Twine and Rope are of unequaled make, and prices as low as first quality Twines can be sold by any reliable business firm in this country. Samples and prices (naming amount wanted), upon application.

\section{GARDENING AND HORTICULTURAL TOOLS.}

A full line, of which we will mention the following :

Forks-Digging and Spading-Hay or

Stable

Forks-Manure and Short Handied. .30 to 1.25

Grafting $W a x$, in $1 / 4,1 / 2$ and $1 \mathrm{lb}$. pack-

ages, per lb

Grass Hooks, each

Grass Edging Knives......-.

Hoes-A full line -
Rollers-Garden and Field. $\$ 9.00$ to 50.00 Scythes-Brush, short blade Grass and Grain, cast steel, in sizes.. Scythe Stones-Different kinds, $75 \mathrm{c}$ per dozen; each. Saws-Pruning and Grafting--------.Transplanting Trowels_.........

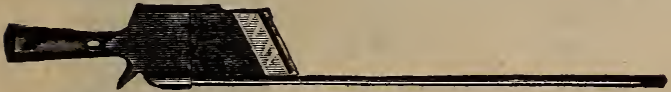

Allen's New Century Pruner is operated from the ground and is guaranteed to do better, also more work with less labor, than any other pruner made. Price $\$ 1$.

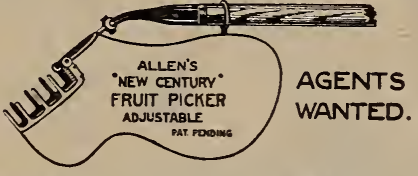

Allen's New Century Fruit Picker does not injure fruit and is the only practical fruit picker made. Price $\$ 1.00$.

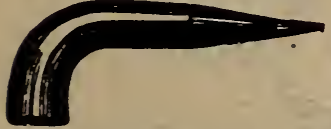

Transplanting Dibbler, 40c.

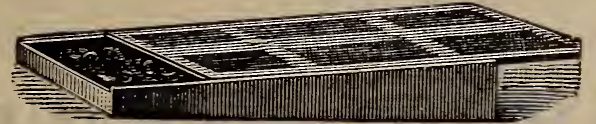

Hotbed Cloth.

Hrtbed Protecting Cloth-Specially prepared to prevent mildewing and rotting, valuable for forwarding and protecting early plants from frosts, covering hotbeds and frames in Spring, in lieu of glass, and for throwing over bedding plants at night in Fall, for Chrvsantemum houses, etc, at one-tenth the cost of glass. Pieces contain from 40 to 60 yards. Price, heavy grade, per yd 11c; by piece per yd. $10 \mathrm{c}$; medium grade, best for general purposes, per yard, $10 c$; by plece, peryard, $9 c$.
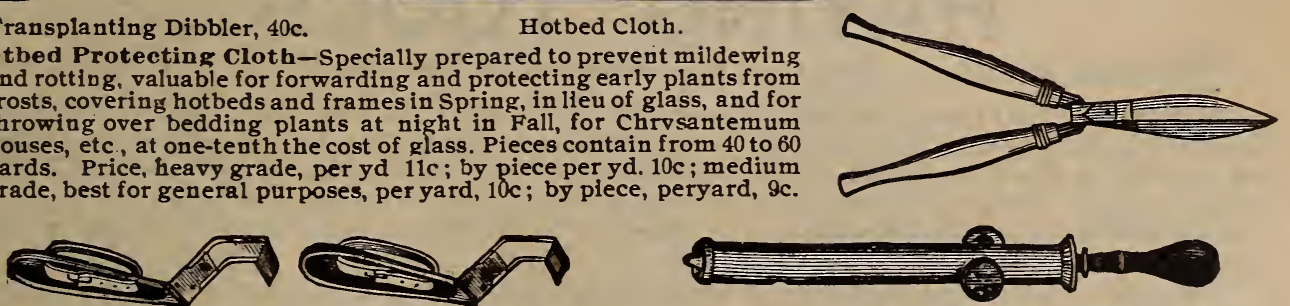

Weeders-Iang's, Noyes and other makes. Price. 25c.

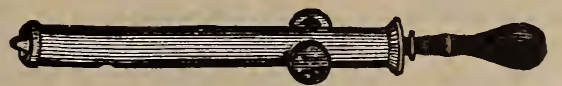

Greenhouse Syringes, $\$ 1.25$ to $\$ 6.50$.

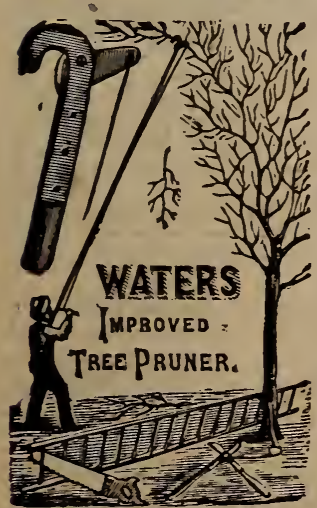

Price. 75 c. to $\$ 150$

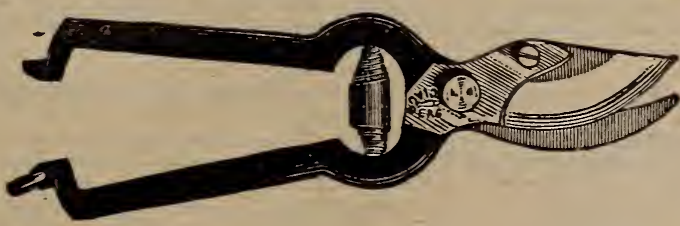

Pruning Shears-Solid Steel, improved springs and others 50c. up to $\$ 1.25$.

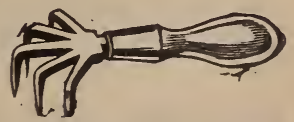

Price, 15 cents.

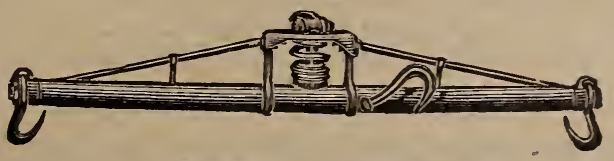

The Wilson Spring Whiffletree. Price, pair, $\$ 1.40, \$ 1.65, \$ 1.75$. 


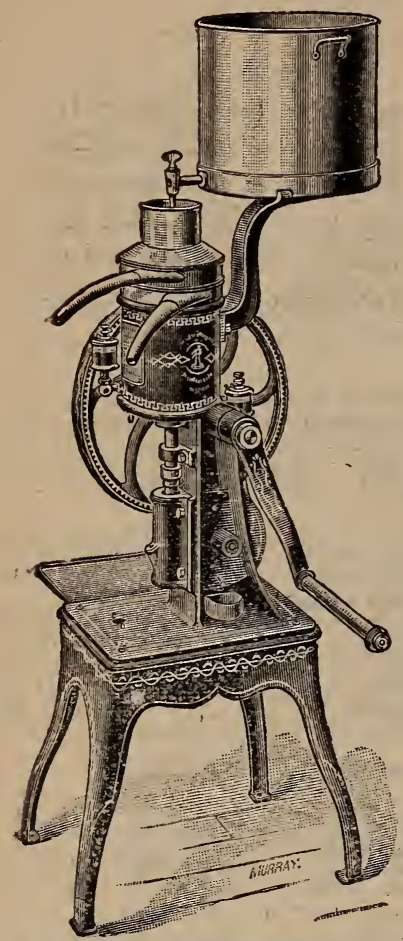

DE LAVAL CREAM SERARATOR.

\section{THE DE LAVAL CREAM NEPARATORS.}

Universally considered the very best Cream Separators made. The purpose of a Cream Separator is the quick and complete separation of cream from milk and this is acromplished to perfection with the De Laval. We offer them at the following prices delivered at your railroad station, freight paid, and shall be pleased to hear from our friends when in the market to buy.
Baby, No. 0

Humming Bird - "

Baby, No. 2

Baby, No. 3

Dairy Steam Turbine.....-..--

Repairs for same in stock.

\section{DASH CHURNS.}

No. 1 Union Churn, ho'ds 5 gallons...... price, $\$ 350$

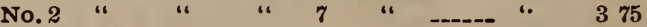
No. 3 " " 10 " 10 " No. 4 " " 4515 "

\section{BARREL CHURNS.}

No. 0 Barrel Churn, holds 6 gal's_-price, $\$ 300$

No. 1 " " " " 10 ".

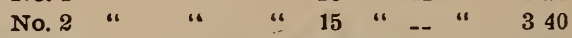

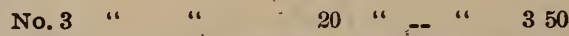

No.4 " " 4 " $\quad 25$ "

No. 5 " " " " 35 " 35 . " 600

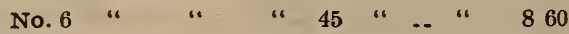

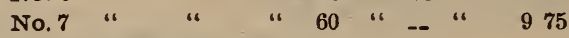

Barrel Churns should never be filled quite half full. 


\section{FEED MILLS AND CRUSHERS.}

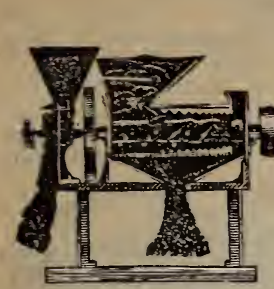

THE CHAMPION.

The Kelly Duplex Feed Mills, all sizes

The Non pareil Feed Mills all sizes_........... 4000 to 20000 The Champion Combined Feed Mill and Corn ShellerThe Ohio Corn and Cob Sweep Feed Mill French Buhr Stone Farm Mills

6000 7500 to 2200

All the before named Mills will crush and grind corn on the ear into fine meal; also any kind of grain separate or mixed. Descriptive circulars, giving full information and prices of same upon application.

\section{Agricultural Furnaces, Caldrons and Kettles.}

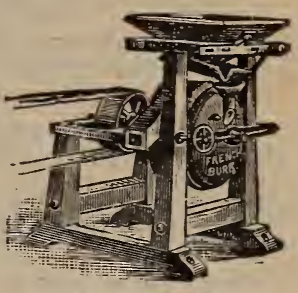

FRENCE BUHR.

Agricultural Portable Furnaces and Farmers' Boilers, complete-3/4, 1, 11/2, 2 and 3 barrels. Also Caldrons for same. IRON KETTLEs, from 5 pails up to 5 barrels, at lowest market price.

\section{THE PHILIPPS IMPROVED EEED COOKER.}

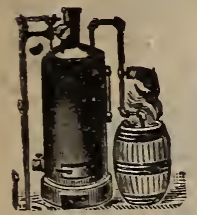

The illustration shown faithfully represents our Steam Feed Cooker or Agricultural Boiler, and we believe it to be the best Cooker ever placed on the market. It is made in the most substantial and workmanlike manner. The material used in its conscruction is the BEST BOILER PLATE STEKL 60,000 pounds tensile strength, hand riveted, tested to 100 pounds hydrostatic pressure, sfcuring perfect safety and ample capacity to users. The fire door is of ample size, and the grate is so designed that any kind of fuel may be used. The boiler is of the tubular type, the flues passing through the water, giving unusually large heating service, and as durable and efficient as any engine boiler of same dimensions.

FEED COOKER.

\section{SIZES AND PRICES.}

No. 1.-Diameter of shell, 19 inches; height of shell, 40 inches; number of 2 -inch flues, 9 ; length of boiler, 54 inches; shipping weight, 360 pounds; price, $\$ 25.00$.

No 2-Diameter of shell. 19 inches; height of shell, 40 inches; number of 2 inch flues, 13 ; length of boiler, 58 inches : shipping weight. 430 pounds ; price, $\$ 77.50$.

The following fittings and trimmings are furnished with each Cooker: One safety valve, two gauge cocks, one pump, two valves, glass water gauge, steam gauge, sufficient pipe connections, and two feet of hose. It is fitted with connections for one task or barrel, but may be used with three or five, with additional pipe aud fittings. Send us your order for one.

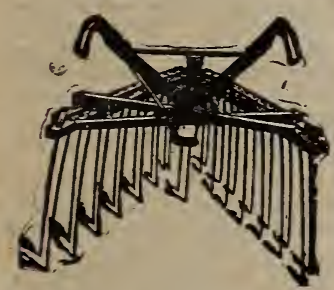

\section{Keystone Adjustable Weeder and Cultivator.}

This Weeder we introduce on its merits and can truthfully say that it is the VERY BEST Weeder made. Every farmer and gardener should have one. Price, $\$ 8.50$.

The Little Giant Hand Broadcast Seed Sowers.

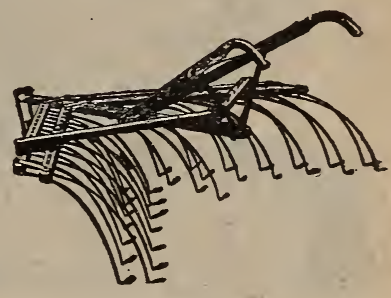

The Greatest Labor and Seed Saving Iaventirn of the Age. The Crank or Geared Seeder will be preferred by many. They are the best, as to work and durability, at onehalf the cost of other makes.

With Metal Bow and Agitator or Force Feed.

This is the BEST BUILT, easiest running, most perfect machine in the market It saves one-third seed and two-thirds labor. Weighs but three pounds. Man or boy can sow on hilly, stumpy, stony and rough, as we 1 as on clean and old land, perfectly even any desired quantity (one quart to three bushels per acre) of Clover, Timothy, Millet, Hungarian, Flax, Wheat, Rye, Oats, Peas, Corn, Orchard Grass Blue Grass, $\cdot$ Red Top or other seed, Fertilizer and Ashes, etc. price for Bow Seeder, single one, $\$ 175 ;$ three in one order, $\$ 5.00 \%$ six in one order; $\$ 9.00$; single crank Seeder, $\$ 25$ : three in one order, $\$ 00$; six in one order, $\$ 1200$, to any place in the United States.
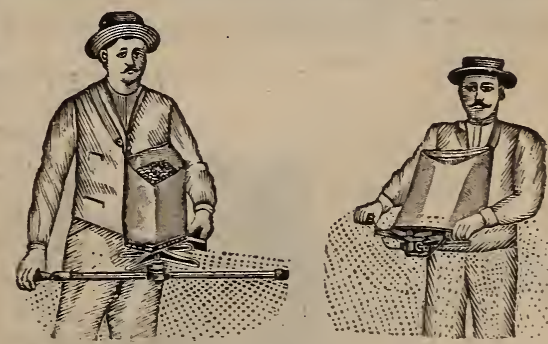
Express charges prepaid by us. SPECIAL PRICE FOR LARGER ORDERs. Fully warranted the best out. It is the best implement of its kind and for the money on earth. No farmer who has used one would do without it for five times its cost. Strongest, prettiest and lightest running No equal on the market. A liberal discount to agents and dealers: write for special circular and directions. We sold thousands of them in the last few years and every one gave the best satisfaction, as hundreds of the most flattering testimonials from all parts of the United States will testify. We guarantee either one to give entire satisfaction. We allow $50 \mathrm{c}$ on each single Seeder and 25:. each on orders for three and six, ordered and shipped with seeds, etc., at purchaser's expense.

No careful, economical farmer will continue to sow his seed by hand (the old style) when he can get one of these machines at our reduced prices. They will save their cost almost daily iu saving of the seed, to say nothing about saving of time and more even distribution, which will have a great effect on the crop.

\section{W. A. WOOD, HARVESTING MACHINES, Etc.}

Agency for the celebrated Walter A. Wood Mowing and Reaping Machine Co. Binders and Mowers; Royce Single Reapers and repairs for same. Keystone and Rosenthall Corn Huskers and Fodder Shredders-the best machines made for this work. Satisfaction guaranteed.

Grain Drills, Cider Mills, for hand and power; Wheelbarrows, garden and canal; Scales. counter and warehouse ; store and warehouse Trucks; Farmers and Gardeners' Steel Tools, Shovels, Spades. Scoops, Hoes; Iron, Steel and Wooden Rakes. A full line of the most Improved and best Lawn and Garden Tools made. which we guarantee to be as represented, and sell them at the lowest price possible. 


\section{LEVER AND TREAD HORSE POWERS.}

The Improved Champion Lever Horse Power, also Heebner's Tread Powers, and we guarantee them to be the best in the market. At bottom prices. Be friendly and write us your wants.

Church, School and Farm Bells.

The celebrated Blvmyer Bells for Churches, Academies, Schools, Court Houses, Fire Alarm, Factory and Farm. Unrivaled for sweet ness, purity of tone and durability. Kindly let us know what kind; size and tone Bell is wanted, and we will send descriptive circulars and prices. They are guaranteed for two years, and if broken at any time will replace a new Bell for one-half the price.

Crystal Metal Farm Bells, Nos. 1 to 5 , from $\$ 1.25$ to $\$ 3.00$ each.

\section{Hand and Barrel Carts.}

This style Hand Carts, 36 inch wheel, box $24 \times 36$ inch.. 10 inch deep, $\$ 5.50$. Hand Carts with removable end boards, $\$ 6.00$. Larger sizes from $\$ 7.00$ to $\$ 10.00$.

Barrel Cart, with and without the barrel. Price, with barrel, $\$ 5.00$ without the barrel, $\$ 3.50$. Any ordinary water barrel will fit, and i bolted to the axle, and the barrel is held upright and in position by the frame, used also as a handle or shafts. The barrel can be taken out and put in without any trouble, and a box substituted.

\section{THE IMPROVED CLIPPER GRAIN AND SEED CLEANER.} The Most Perfect, Strongest and Cheapest Mill on Earth. This MIll will do what no other Mill ever has or will do.

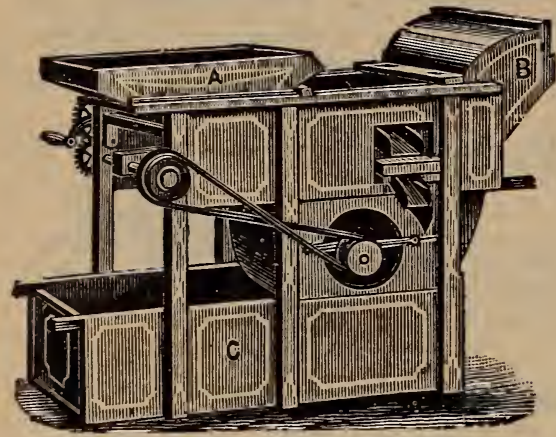

This Clipper Mill No. 1. is for general use, is furnished with eight sieves, suited for all kinds of grain and seed, seven of which are zinc-the best material for sleves as it will not rust. This Mill cleans Wheat. Oats, Rye, Barley, Corn, Rice, Beans, Buckwheat, Coffee. Spice, Flax, Clover, Timothy, Millet, Hungarian and all other grasses and garden seeds with once through, and leaves no tailings to be recleaned. They separate Peppergrass, Plantain, Buckhorn and other foul and noxious seed from Clover and Red Top, Plantain and Peppergrass out of Timothy Seed. The only Mill which separates Red Clover, Timothy, Dock and noxious seed from Alsyke Clover. It separates Cockle and Mustard from Wheat and Oats. You can grade all your grains perfectly for seed.

Another important and strong point of the Clipper Mills over others is that they are more compact and stronger built They have a large box which the grain and seed drops into, and the price is as low as any ordinary mill. Nos. 1 and 2 Clipper Mills, for hand power; Nos. 5, 6, 7, 9 and 10, Clipper Mills, for power only.

Price, No. 1, $\$ 20.00$; Price, No. 8, $\$ 30.00$. Special circulars malled on application.

\section{FEED CUTTING BOXES.}
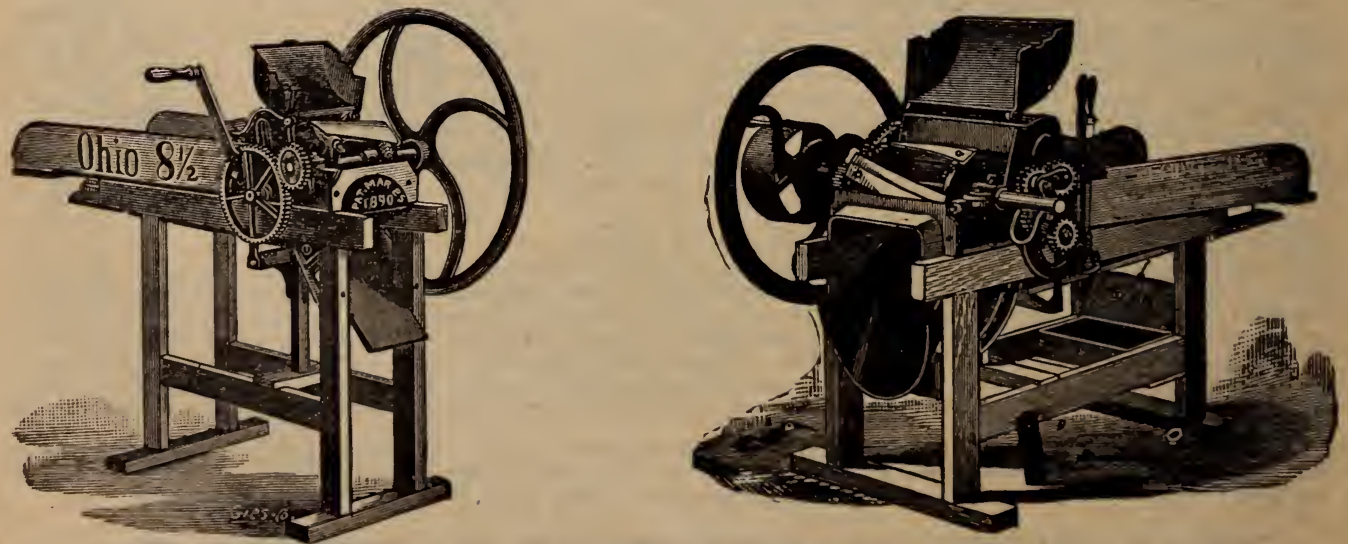

We have the largest assortment and best selected stock of Feed Cutters of any concern in the State. We have a full line of the celebrated SWISS FEED CUTTERS and the famous OHIO Ensilage and Feed Cutters; also the Improved CUMMINGS Feed Cutters, with Carriers for elevating Ensilage and Dry Fodder, for all large sizes when wanted. Our prices are low. We have Cutters, for hand and power, from $\$ 3.00$ upwards to $\$ 125.00$. Call or write for special circular and prices.

\section{Corn Planters and Drills.}

Deere \& Mansur one and two-horse Corn Drills and Planters, with and whout Fertilizer attachments. Also other makes one and two-horse planters from $\$ 5.00$ upwards.

Please let us know what you want, when we will send circular and quote you rock bottom prices. 


\section{IMPROVED HAND CORN PLANTERS.}

Smith's Celebrated Ohio Corn Planter. This Planter has stood the test for 39 years, and never failed to receive the highest commendation in a single instance. Price, $\$ 2.00$. Special price in dozen lots.

The Celebrted American Band Plunger Corn Planter, greatly improved, $\$ 1.25$ each.

The Eureks, Triumph, and other Eand Corn Planters, 75c. to $\$ 1.00$ each; less price for dozen lots.

\section{ACME HAND POTATO PLANTER.}

This is the pioneer implement of its kind. Simple, Practical, Durable. It is the lightest (weighs but $21 / 2$ pounds), strongest and most durable Hand Potato Planter yet made. Puts in the seed cheaper, easier and better than any other method. Works perfectly in clay, gravel or sandy soll, sod or new ground. Any farmer with less than thirty acres of potatoes to plant can put his seed in CHEAPER WITH THE ACME PLANTER than by any other way. It is considered a good day's work for a man to plant three-fourths of an acre of potatoes in a day. With an ACME PLANTER a man can plant TWO ACRES in a day of ten hours. $\$ 1.00$.

It makes the holes, drops and covers at one operation. Once over the field does the work. Special price,

\section{TOOLS FOR TOWNSHIP OR CONTRACT WORK.}

Columbus Solid Steel Square and Pressed Bowl, Wheel and Drag Scrapers.

No. 1-Boss Pressed Bowl Steel Scraper .... No. 2 " " " " "

No.3- " " " " " "

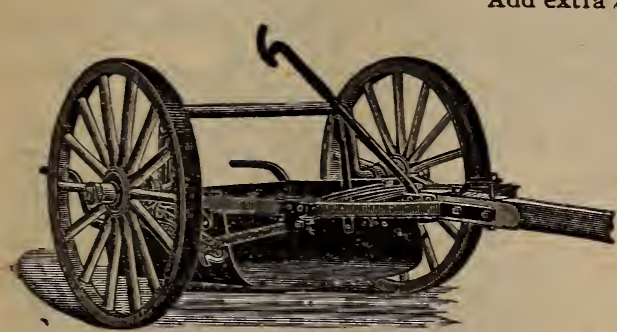

COLUMBUS WHEEL SCRAPER.

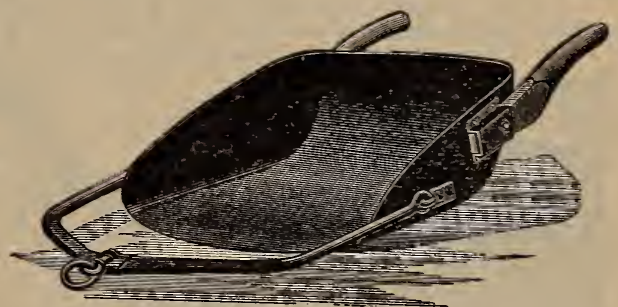

BOSS SOLID STEEL SCRAPER.

No. 1 . No. 2 $\$ 25.50 \quad \$ 35.00$

No. 3.

$\$ 38.00$

39.00

Oolumbus Wheel Scraper-Square Bowl $\$ 1.50$

Doan's Patent Board Scraper-One size

Be sure to buy no other make, even for less money, as the GENUINE DOAN is the oNLY ditching scraper worth buying.

We carry in stock heavy grade and contractors' Plows, suitable for two to ten horses. Also, agency for steam or horse RollrRs, Road Machines, etc. Can furnish Matrocks, Picks, SHovels, etc. So please let us know your wants in that line, when we will name you right prices for best goods money will buy.

\section{Y N A M I T E.}

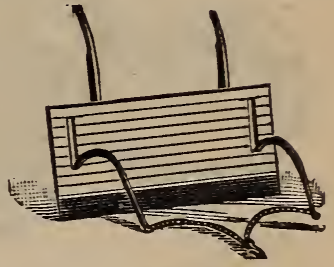

DOAN'S SCRAPER.

For blasting stumps and boulders there is no other explosive so effectual and safe to handle. Farmers can readily make kindling wood of their stumps, and the crops grown in the place they occupied will pay the expenses of the powder in a few seasons. It is manufactured in all grades and sizes. Best results in Stump blasting are obtained by boring a hole under the stump in the ground, so as to locate the charge under the point of greatest resistance-up-hill side is best, then ram in the charge, taking care that it is located in good solid ground and not in some hollow or rotten center; then tamp the hole perfectly on the charge and fire. With little experience by any farmer, he can make results like picture shown. The fragments can be piled up and in a few weeks burned up, as the dirt is blown off and larger pieces splintered by the blast.

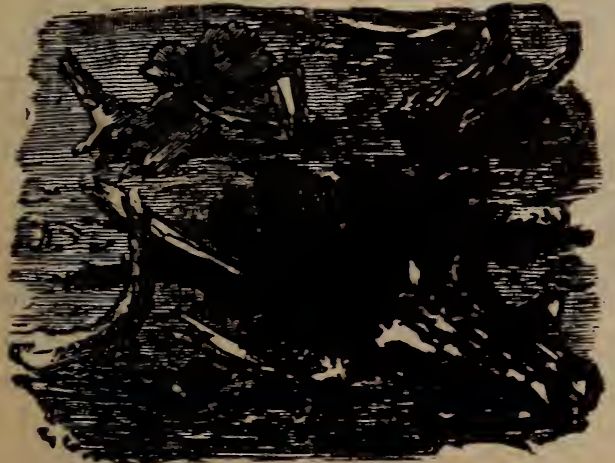

Per $1 b$.

No. 20 contains 20 per cent. nitro glycerine. $\$ 018$

No. 30

No. 35

No. 40

No. 45

No. 50

No. 60

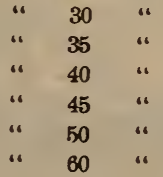

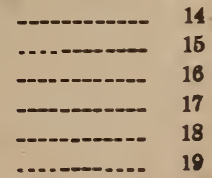

Double Strength Caps_.....___._._._._ \$6 00 per $1 \mathrm{nno}$

Treble " "

Cotton Safety Fuse........._.......... @ 300 " $1000 \mathrm{ft}$.

Single Tape "

Double " " 


\section{IMPROVED CUTAWAY AND OTHER HARROWS.}

The famous Clark's Cutaway Harrow supersedes the plow and makes a perfect seed bed. Clark's Improved Cutaway Harrow is "The Boss." It beats anything in the way of a Spading and Pulverizing

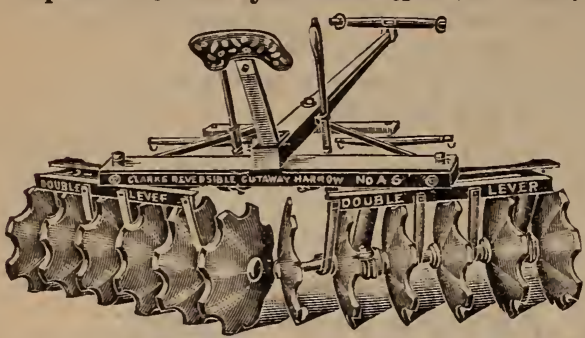
Harrow ever introduced. With it you can prepare your land for Oats seeding without plowing. They have no equal. We have tested them with ot her so-called Spading Harrows and found they were no competitors to the CUTAWAY. Hard clay or stubble made into a perfec seed bed. Has also a seeding attachment for sowing all kinds of grain and grass seed. We have all slzes of them, for one, two and three hor,es. Also Cultivators tor use in corn, orchards and vegetable gardens for fruit growers especia'ly. No tiller of soil can do without it. We have sold them for the last twenty years and have the most flattering testimonials, and can refer to hundreds who use them. We have the ExcLO. SIVE AGENCY for them in this section, and sell them at manufacturer's prices. Call and see or send for full descriptive circular and prices. Price, $\$ 22.50$ for two-Horse Harrow.

Clark's Cutaway Sulky Disc Plows. Catalogue and prices upon application.

Diamond Steel Tonth Harrows. These Harrows with patent Steel Teeth, each tooth riveted, which prevents splitting. We have 48-tooth, cutting 8 feet ; $60-1$ ooth, cutting 10 feet ; 72 tooth, cutting $211 / 2$ feet. These are all Hinge Harrows - hinge made of wrought iron. We have a section Harrow, with long eveners, sold by the section, 20 teeth in each section. Two sections, 40 teeth cuts 8 feet; three sections, 60 teeth, cuts 13 feet, steel teeth riveted. These are for small gardeners. Price, from $\$ 3.00$ to $\$ 12.00$.

The Tiger Protection Steel Frame. Spring Teeth. Nloating Harrow; The Tiger Protection Wood Frame. Spring Teeth, Floating Hurrow-of different sizes and prices.

Evans' Adjustable Steel Frame Lever Harrows, 5060 and 70 Solid Steel Teeth. It is acknowledged to be the most perfect Harrow on the market. Price, $\$ 9.50, \$ 10.50$, and $\$ 11.50$ each.

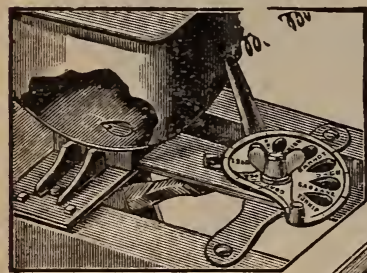

NEW PERFECT INDEX

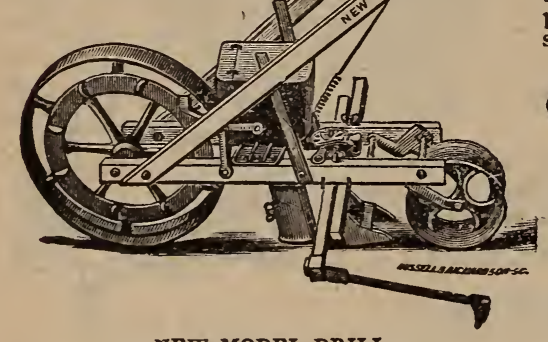

NEW MODEL DRILL.

The ew Model seed Drill. One of the best Drills made. It has many advantages over other Drills. It has an excellent marker, a broad wheel lending ease to work the machine; a good covering roller. The flow of seed can be stopped instantiy by means of a string attached to your hand. The in-

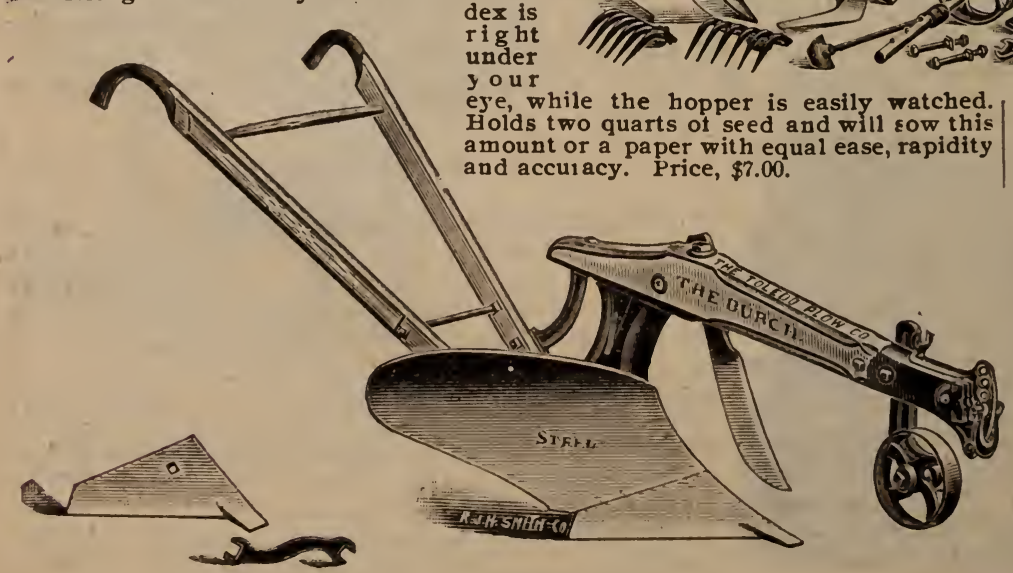

The No. 6 "Iron Age" Combined Double Wheel Hoe, Hill and Drill Seeder. Packed weight $50 \mathrm{lbs}$. This tool is similar in construction to the No 4 Combined Double Wheel Hoe and Seed Drill. As a Single or Double $\mathbf{W}$ heel Hoe it is identical. We will only speak of it wherein it differs from the No. 4 Drill. Besides drilling it will also drop in hills at $46.8,12$ or 24 inches a part all the small seeds varying in size from celery to corn. By a convenient hook the 1001 can be instantiy changed to drop from bills to drills or vice versa. It is clog proof. All trash which may come in contact with it is ridden down. By a thumb screw it can be instantly adjusted in dept h. The Marker is pivoted in the rear of the Hopper and can be thrown from side to side by the foot. Price, No. 4 Iron Age Drill, $\$ 9.00$; No. $6, \$ 10.00$.

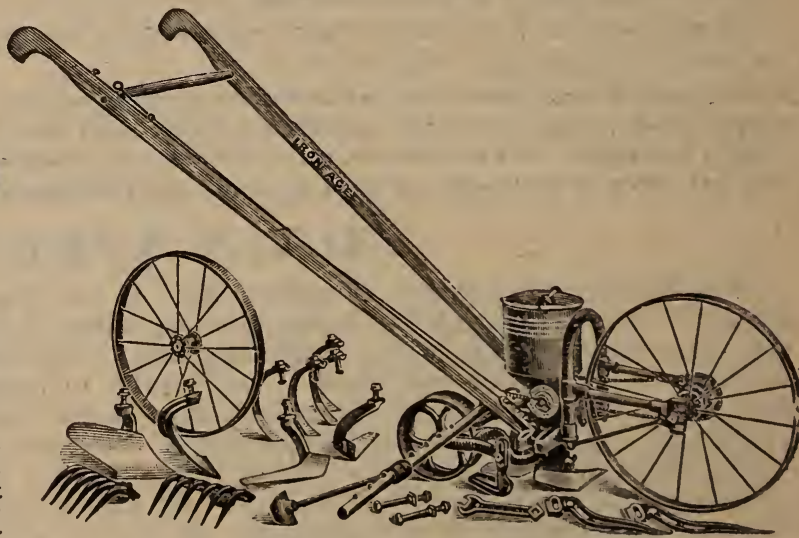

The Toledo Burch Plow, the best Plow made. Guaranteed to please or money refunded.

\section{PRICES.}




\section{"Planet JR." GaRden TOOLS FOR 1902.}

Space will not permit illustrating and describing all of the "Planet Jr." tools, but we will gladly send a fully illustrated Catalogue to any who desire it ; and we can supply promptiy any'hing ordered. "Planet Jr." goods are standard machines, the best on the market. In sending your orders to us. you can rely on getting bottom prices. Prices reduced this year.

\section{THE "PLANET JR." No. 1 COMBINED DRILL \\ AND WHEEL HOE.}

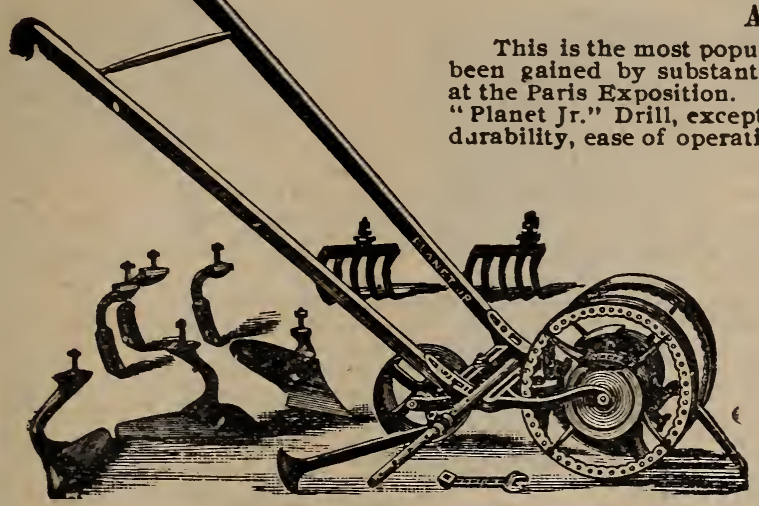

pular combined tool known and its friends have tial merit alone. It won the highest award alt "Planet Jr." Drill, except in size, and has all its merits, its strength, and perfection of work.

\section{PLANET JR." 12-Tooth Harrow.}

This comparatively new tool has grown rapidly in favor with market gardeners and strawberry growers. It is carefully made and $f$ nished, has a high frame and the chiselshaped teeth cul an inch wide each, and may be worn dow $\mathrm{n}$ three inches before that width is lessened or the teeth worn out; even then they are cheaply replaced.

It may be set with teeth trailing by simply changing one bolt in each tooth.

The foot lever pulverizer is a capital addition for preparing gruund for the seed drill or for plant setting. Hand levers regulate

both width and depth while in motion; it contracts to twelve inches, and may be further reduced in width by taking of the outside teeth : it expands to thirty-two inches. It cultivates deep without throwing earth upon the plants and the smooth, round. throated teeth turn strawberry runners without injuring them. See price list, page 88 .

Thousands of farmers and gardeners who own this tool save its cost one or more times every year, for in an onion field and among many other crops, one can do more and better work with it than six men with ordinaty hoes. It is invaluable for all market garden crops. The wheels are only ten inches high, as a high wheel is wrong for a Wheel Hoe,

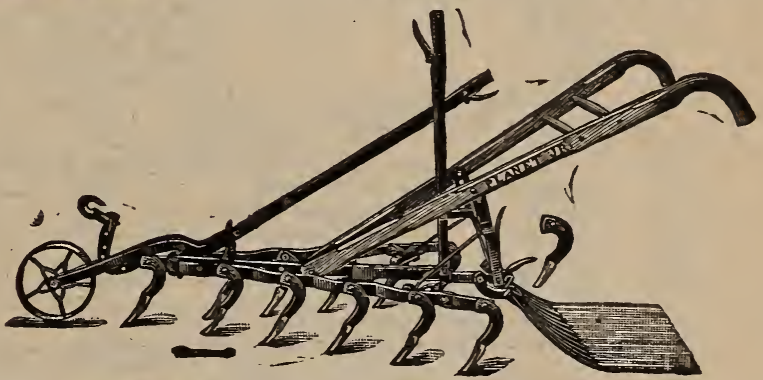

"PLANET JR." No. 11 Double Wheel Hoe, Cultivator, Rake

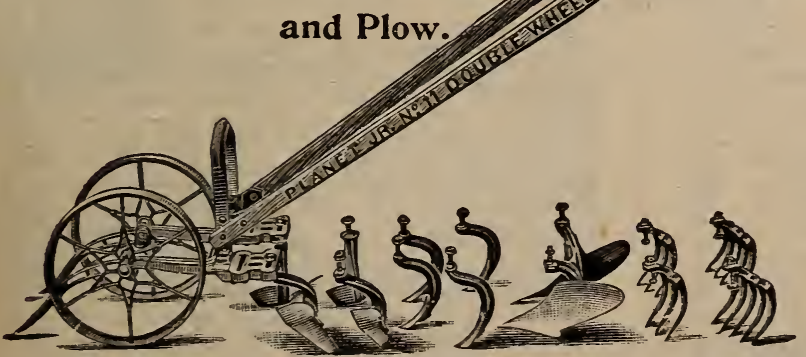

since the wheels are' simply depth regulators. not load carriers.

The "Planet Jr." Double Wheel Hoe will straddle plants 18 inches high, and finish rows from six to eighteen inches apart at one passage. One hoe sets slightly ahead of the other to prevent dragging out young plants. The new frame permits the changing of attachments WITHOUT REMOVING THE NUTS. All the too!s shown in the cut go with the machine for the price: and all blades are steel, hardened in oil and polished. The wheels are adjustable to make the work shallow or deep, as required, and to adapt the machine to all width rows. The tool is charming in every style and kind of work, the admiration of all who see it in operation, and is the acknowledged standard the world over.

To accommodate those who have little work but hoeing. we offer the above michine with hoes only, under the name of "Planet Jr." Plain Double Wheel Hoe at $\$ 1.5 \%$. The other parts can be added at any time and will be found to fit.

\section{The "Planet Jr." No. 8 Combined Horse} Hoe and Cultivator.

This well-known and popular tool, though acknowledged for years past to be the best in the market, has striking improvements for 1902. As a Horse Hoe with side teeth reversed it cuts close to the row without injury to the roots, lea ing but little and in many cases nothing for the hand hoe. As a cultivator. the reversible teeth cut off and turn over the weeds in the most perfect style. As a Hiller, the side teeth work in combination with the rear shovel to pertection. We can supply large variety of attachments for these machines; full information will be mailed upon application. See price list, page 88 .

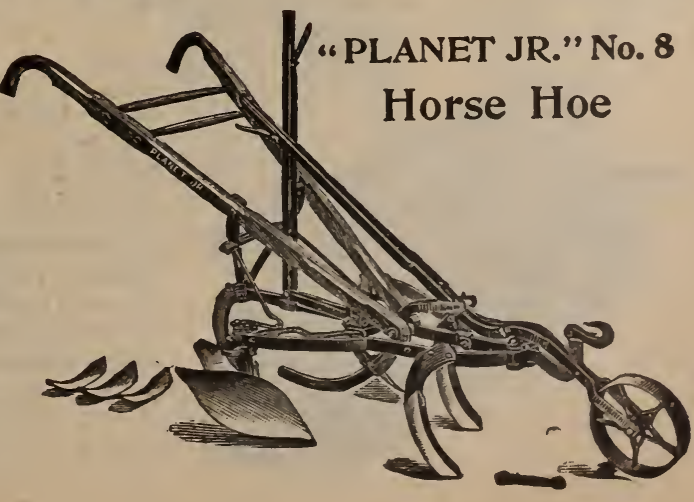




\section{"PLANET JR." 1902 PRICE LIST.}

Call and see or send for "Planet Jr." Special Catalogue, fully describing and illustrating a large variety of hand and horse power implements, superior to any other makes in the world.

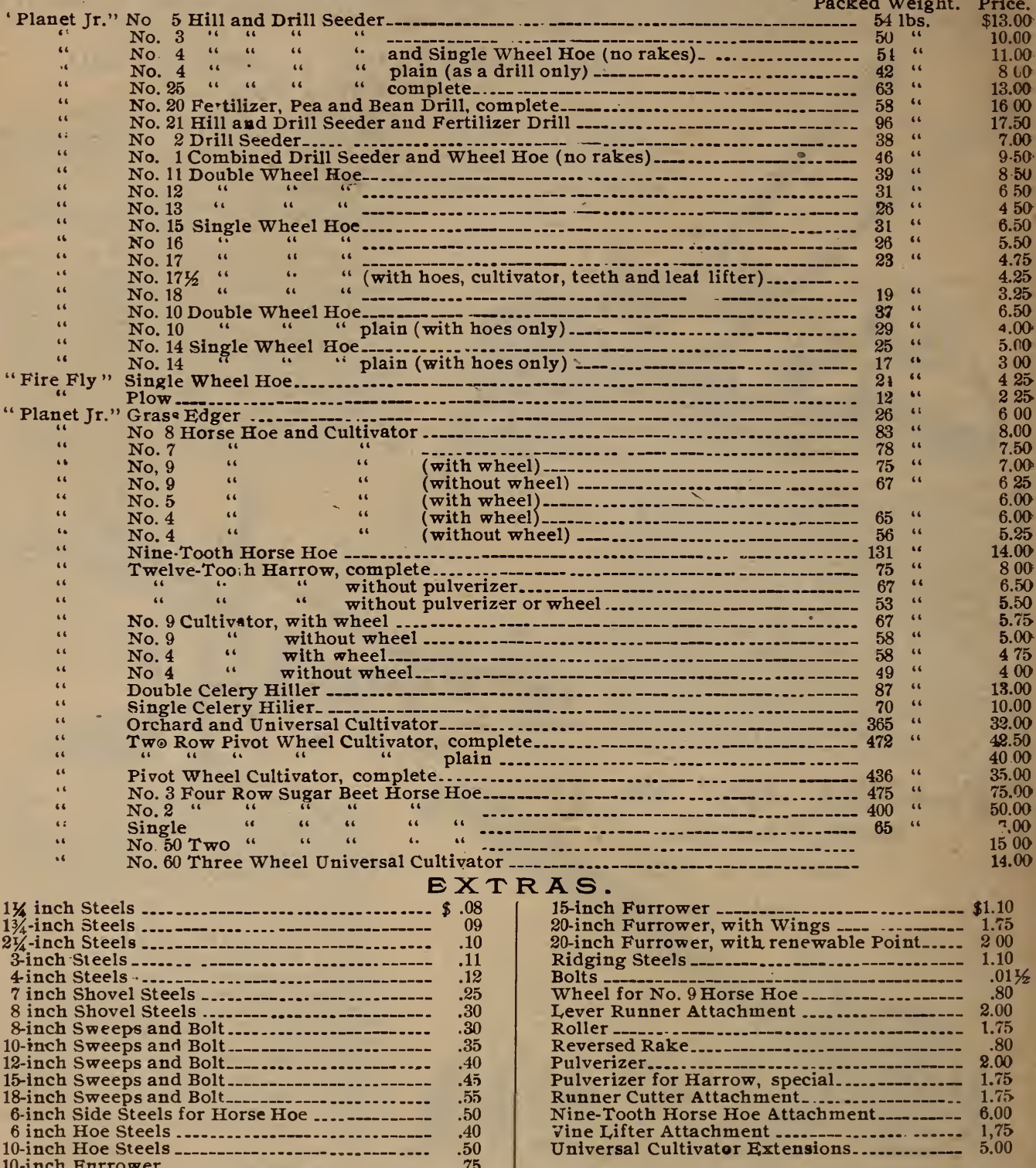

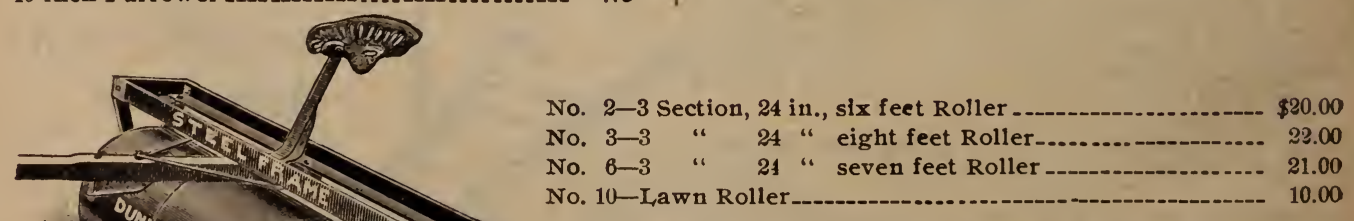

All these Rollers have heavy steel axles. The journals are lathe turned, The boxes are babbited and contain a large compartment filled with cotton waste and when this waste is once saturated with oil, the journal oils itself for the season. The Rims are made from single sheets of HARDENED STEEL-making the best Roller on the market. 
Mastica and Old English Glazing Putty, Mastica Machines and Putty Bulbs. Florists' Tinfoil, Wax Paper, Silkaline, Immortelles and Chenille, Boston Florists' Letters and Script, White Doves, Gal ax Leaves, Stemming Wire, Wire Designs, Pot Labels, Toothpicks, Flower Pots and Saucers, Watering Pots, Sphagnum Moss, Tobacco Dust and Stems, Etc.

\section{FLOWER POT SHUCERS}

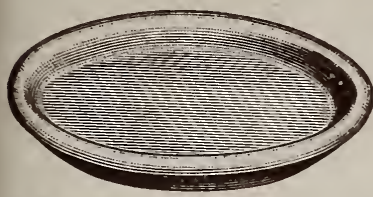

100 in crate 4 inch........... $\$ 6.00$ per 100

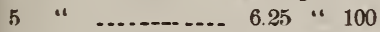
6 “ 6 c......... 6.75 “ 100 7 $\quad$ " $\quad$........... 7.10 " 100 8 “ 8 .

50 in crate $\$ 8.20$ per 100 8.70 " 100

25 in crate $\$ 10,00$ per 100 17.00 " 100

50 in crate 11 " shallow .-.. $\$ 9.10$ per 100

25 in crate

12 " shallow_... $\$ 10.00$ per 100

13 " shallow...- 1200 " 100

14 " shallow.... 15.00 " 100
FLORISTS' VASES

For Displaying Cut Flowers.

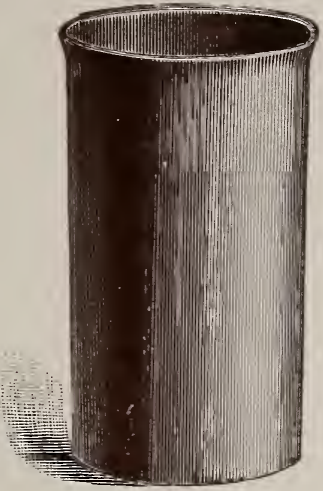

Diam., Depth

inches inches Order Plain inside. inside. by No. per doz.

\section{月 “WHEELING" DISH.}

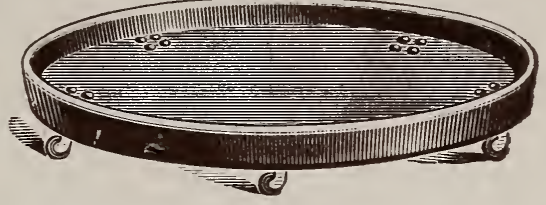

THE FIBRE-WARE SAUCER shown by the accompanying illustration permits of the moving of heavy potted plants, palms, etc., without labor or difficulty. It is entirely free from joints, and consequently perfectly watertight: it is not affected by moisture; cannot rust ; is light, strong and durable. Its ballbearing castors with hard.wood rollers run easily and raise the saucer sufficiently high to permit of a free circulation of air beneath. Its use will speedily pay for its trifling first cost in the saving of carpets or easily-marred hard-wood floors.

$\begin{array}{llll}8 & 13 & 0 & \$ 4.80 \\ 5 \mathrm{I} / 2 & 10 & \mathrm{I} & 42 \mathrm{~J} \\ 4 \mathrm{I} / 2 & 9 & 2 & 3.60 \\ 4 & 6 & 3 & 3.00 \\ 3 & 41 / 2 & 4 & 4.40 \\ 9 & 22 & 00 & 9.00 \\ 51 / 2 & 18 & 11 & 5.40 \\ 41 / 2 & 15 & 2 \% & 4.80 \\ 4 & 12 & 33 & 4.20 \\ 3 & 9 & 44 & 3.60\end{array}$

Outside

diam.

about

12 inches.

14

16

4.20
3.60

Will take
pot
10 inches.
12 “"
14
18
20

20
Per

dozen.

$\$ 6.00$

7.20

9 rO

1000

1200

15.00

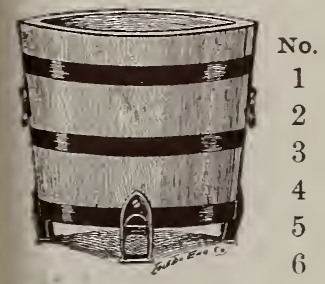

\section{FLOWER AND TREE TUBS.}

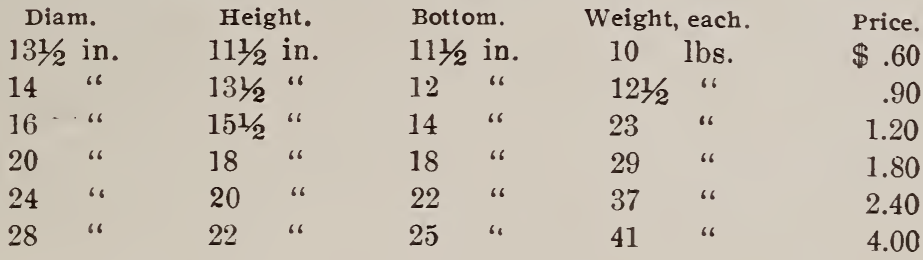

\section{THE CHANDLER MOLE TRAP.}

A new Trap on common sense principles and sure death to the mole that enters it.

A child can manipulate it with perfect safety.

PRICE, \$1.00, F. O. B. Express Toledo.

This is the best Mole Trap on the market for several reasons:

FIRST-It will catch a Mole from two to four inches deeper in the ground than any other trap sold.

SECNND-You do not have to dig up from four to eight inches of your lawn to remove the mole from the ground or weight the trap to prevent it from springing out of the ground when tripped.

THIRD-There are no sharp needle-like spears lying around to endanger the lives of your children or stock.

FOURTH-When set it only extends five inches above the ground and seven inches in the ground, thus being the best trap on the market for HUTBEDS, and it will not interfere with the glass cover.

F IFTH-Being the only trap on the market that is ABSO-

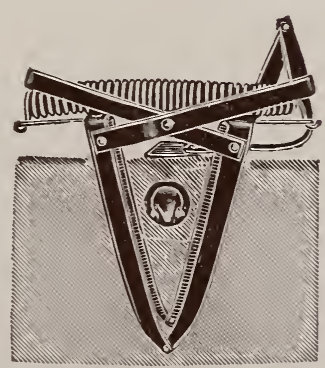

Open as Set.

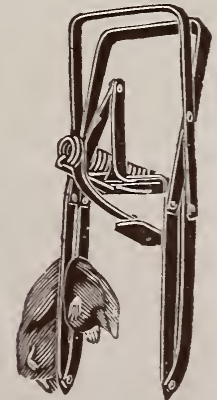

Sprung with Mole Caught. UTELY SELF-SETTING.

This Trap is made of best steel and plated to prevent from rusting.

The first thing to do is to find the moles' regular runawav, which usually starls from a building, a fence or a piece of ground not of ten disturbed. They pass through these runaways regularly about $6 \mathrm{a} . \mathrm{m}$.. $12 \mathrm{~m}$. and $6 \mathrm{p} . \mathrm{m}$ Set your trap on one of these runaways and you are sure to catch all the moles near by. As many as thirty (30) moles have been taken from one of these runaways by a CHANDLER MOLE TRAP. 


\section{OHIO BEARDLESS BARLEY.}

This wonderful Beardless Spring Barley has now been grown by us for several years past with the best results, so we can safely guarantee it in every way as being the very best barley for farmers to raise.

Cattle will leave green clover to feed on the straw.

It is beardless, and the hull remains tight, which fact alone places it at the head of all barley.

Is six-rowed, of unusual length of head, well packed with solid plump grains clear to the tips.

Is the earliest to ripen, hence valuable to plant either in the extreme north or extreme south, and will do equally well in the middle States.

Frost will not hurt it, and it can be planted early in March and ripens in June, therefore suited in every way to be easily handled by the farmer.

The straw is somewhat larger and taller than common barley, but much stiffer, and will stand up on any soil.

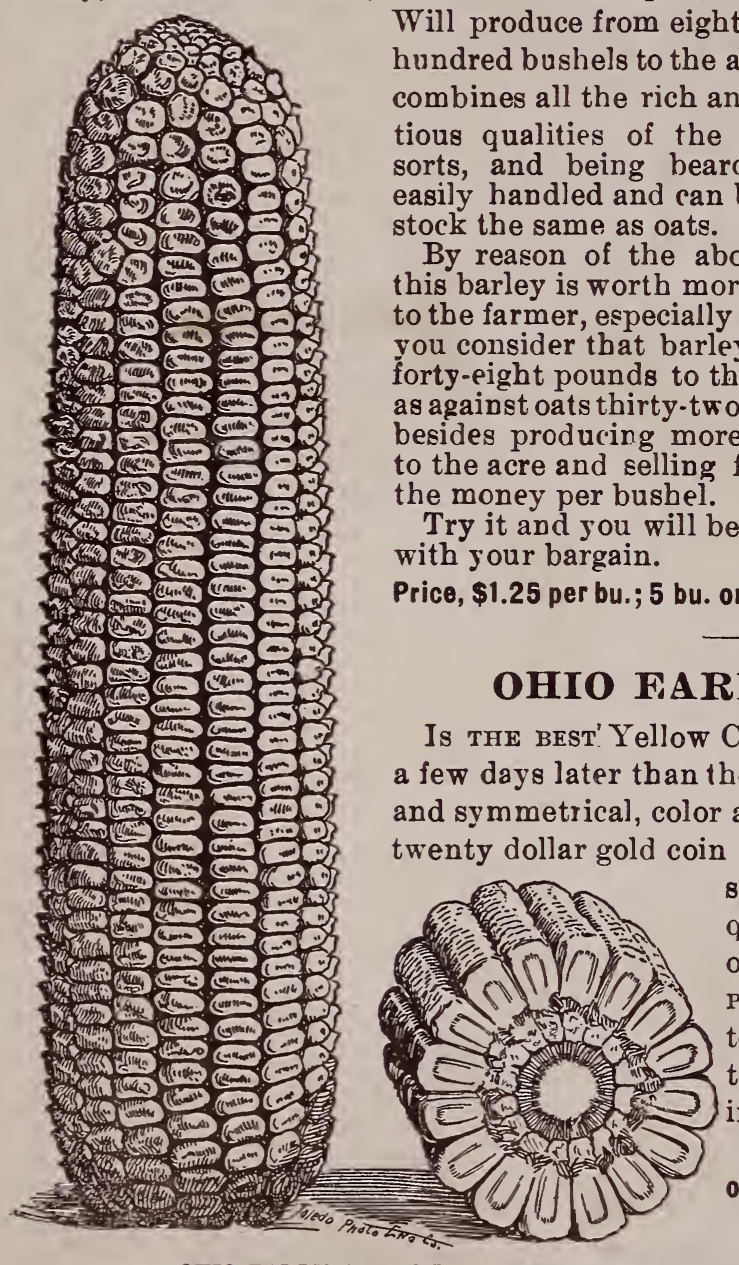

OHIO EARLY GOLD MINE CORN.

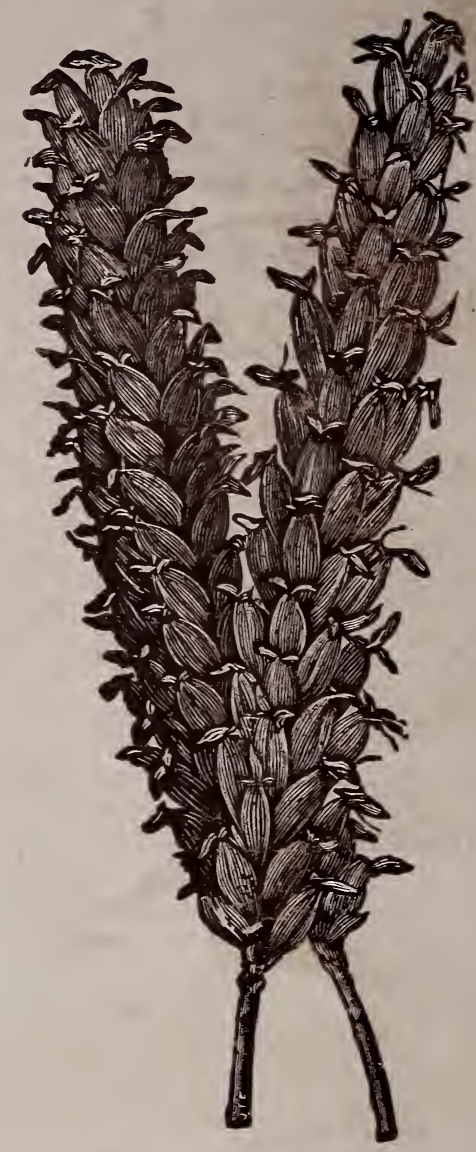

OBIO BEARDLESS BARLEY.

Bags extra, 16c. each.

per bu.

\section{E CORN.}

Is THE BEST' Yellow Corn that grows. It is early, ripening only a few days later than the Pride of the North; ears are of good size and symmetrical, color a bright golden yellow, as handsome as a twenty dollar gold coin just from the mint, grain is very deep, cob small, and therefore it dries out very quickly as soon as ripe. SEventy POUNDS OF EAR CORN MAKE SIXTY TO SIXTY-TWO POUNDS OF SHELLED CORN, and in hauling to market it weighs out five bushels more to the wagon load than common varieties in the same size wagon.

PRICE, peck $40 \mathrm{c}$; bushel $\$ 1.25$; five bushels or more $\$ 1.10$ per bushel.

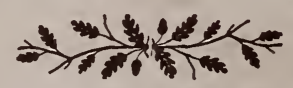

\section{THE HENRY PHILIPPS SEED AND IMPLEMENT CO.}

115 and II7 ST. CLAIR STREET,

TOLEDO, OHIO. 